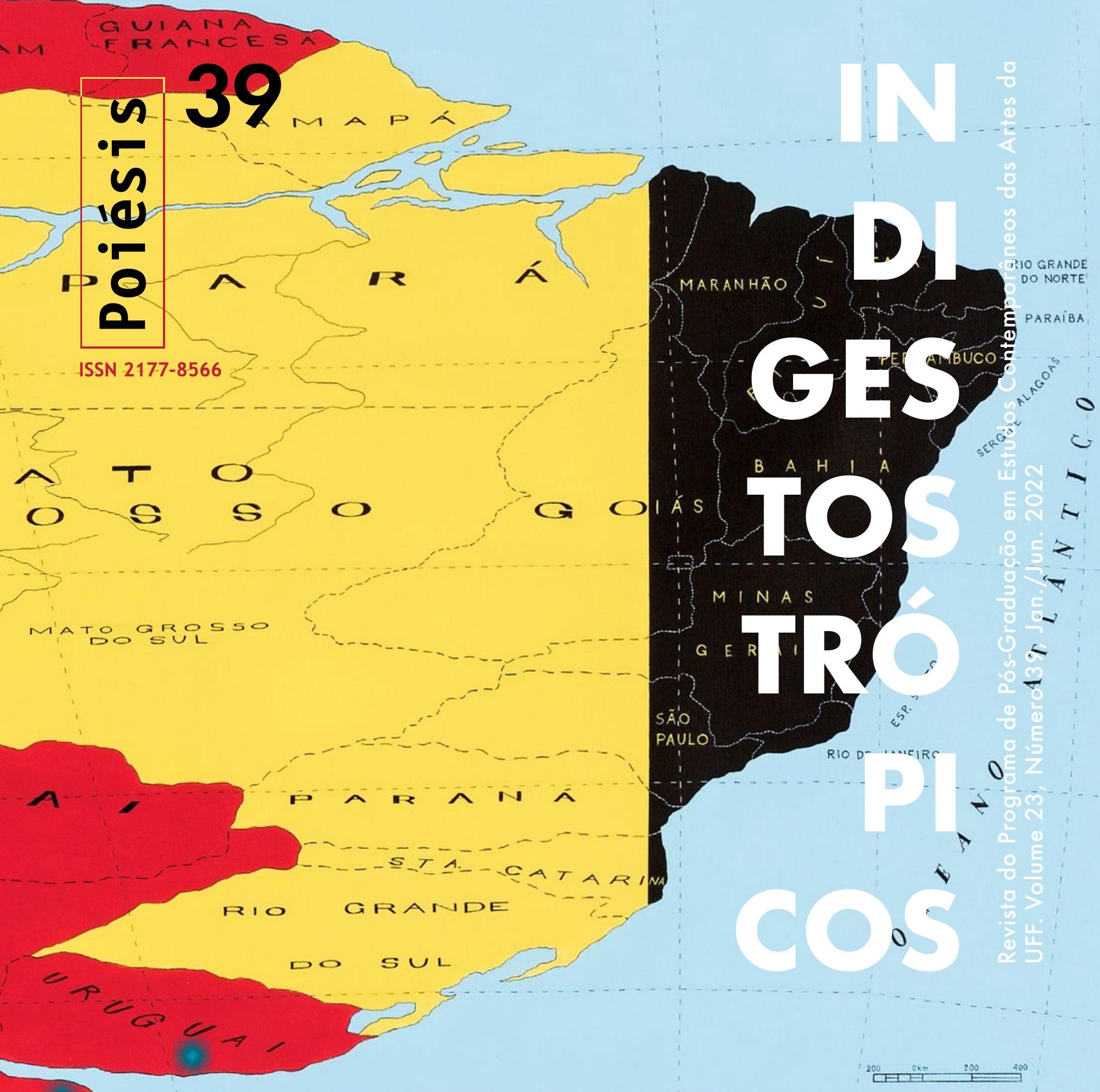




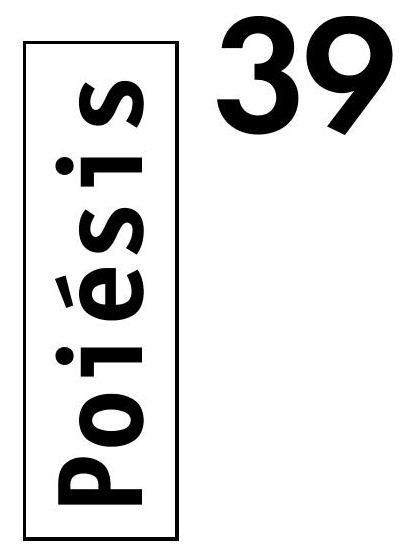

ISSN 2177-8566

Editor LUIZ SÉRGIO DE OLIVEIRA

Organizadores do dossiê ANA CAROLINA PRUDENTE

NASCIMENTO, ANA CLARA SILVA MATTOSO, ANA SAYEG

TRANCHESI, AUGUSTO MELO BRANDÃO, THIGRESA ALMEIDA

hitps://doi.org/10.22409/poiesis.v23i39

Publicação Acadêmica do Programa de Pós-Graduação em Estudos

Contemporâneos das Artes

Universidade Federal Fluminense

Rua Alexandre Moura no 8 - São Domingos - Niterói - RJ - 24210-200

Campus do Gragoatá - Bloco A - sala 202

Telefone: [55+21 ] 2629-9672 - E-mail: poiesis.uff@gmail.com

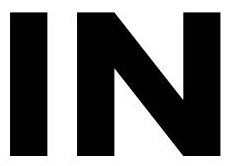

웅

$\stackrel{0}{\frac{1}{4}}$

웅



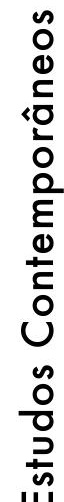
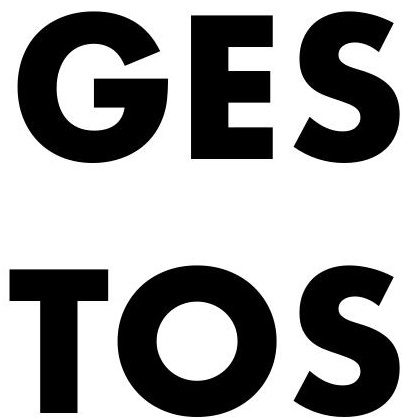

$\cos$

ฮ 은

임

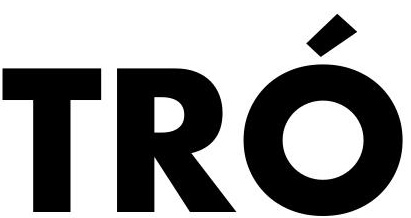

구

은 웅

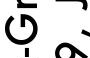

:

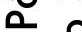

잉 인

온

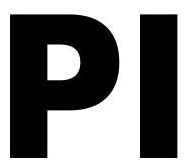

문

뜨

ำ

응 ํㅗㅇ

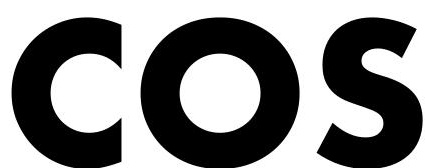

훅우

닐 
A imagem da capa e da quarta capa integra o ensaio visual de Talles Lopes, publicado nesta edição entre as páginas 102 e 114 , intitulado Série Mapas. [Os Editores da Revista Poiésis agradecem a permissão para a publicação da imagem na capa desta edição]. 
UNIVERSIDADE FEDERAL FLUMINENSE

INSTITUTO DE ARTE E COMUNICAÇÃO SOCIAL

REVISTA POIÉSIS | PUBLICAÇÃO DO PROGRAMA DE PÓS-GRADUAÇÃO

EM ESTUDOS CONTEMPORÂNEOS DAS ARTES

EDITOR

LUIZ SÉRGIO DE OLIVEIRA, Universidade Federal Fluminense,

Niterói, Rio de Janeiro, Brasil

\section{EDITORES EXECUTIVOS}

ANA CAROLINA PRUDENTE NASCIMENTO, Universidade Federal Fluminense, Niterói, Rio de Janeiro, Brasil

AUGUSTO MELO BRANDÃO, Universidade Federal

Fluminense, Niterói, Rio de Janeiro, Brasil

LUCAS ALBERTO MIRANDA DE SOUZA, Universidade Federal

Fluminense, Niterói, Rio de Janeiro, Brasil

THIGRESA ALMEIDA, Universidade Federal

Fluminense, Niterói, Rio de Janeiro, Brasil

\section{EDITORES ASSOCIADOS}

BEATRIZ CERBINO, Universidade Federal Fluminense, Niterói, Rio de Janeiro, Brasil

LEANDRO MENDONÇA, Universidade Federal Fluminense, Niterói, Rio de Janeiro, Brasil

LUCIANO VINHOSA, Universidade Federal Fluminense, Niterói, Rio de Janeiro, Brasil

MARTHA RIBEIRO, Universidade Federal Fluminense, Niterói, Rio de Janeiro, Brasil
RICARDO BASBAUM, Universidade Federal Fluminense, Niterói, Rio de Janeiro, Brasil

TANIA RIVERA, Universidade Federal Fluminense, Niterói, Rio de Janeiro, Brasil

TATO TABORDA, Universidade Federal Fluminense, Niterói, Rio de Janeiro, Brasil

\section{CONSELHO EDITORIAL}

ADOLFO ALBÁN ACHINTE, Universidad del Cauca, Popayán, Colômbia

ALEX SCHLENKER, Universidad Andina Simón Bolívar, Quito, Equador

ALMERINDA LOPES, Universidade Federal do Espírito Santo, Vitória, Espírito Santo, Brasil

ANA CAVALCANTI, Universidade Federal do Rio de Janeiro, Rio de Janeiro, Rio de Janeiro, Brasil

ANA MAE BARBOSA, Universidade de São Paulo; Universidade Anhembi Morumbi, São Paulo, São Paulo, Brasil ANA ROSAS MANTECÓN, Universidad Autónoma Metropolitana, Unidad Iztapalapa, Iztapalapa, México

ANDRÉ PARENTE, Universidade Federal do Rio de Janeiro, Rio de Janeiro, Rio de Janeiro, Brasil

ANDREA COPELIOVITCH, Universidade Federal Fluminense, Niterói, Rio de Janeiro, Brasil 
CARLOS AUGUSTO MOREIRA DA NÓBREGA, Universidade Federal do Rio de Janeiro, Rio de Janeiro, Rio de Janeiro, Brasil CAROLINA ARAÚJO, Universidade Federal do Rio de Janeiro, Rio de Janeiro, Rio de Janeiro, Brasil

CAROLINA VANEGAS CARRASCO, Universidad Nacional de San Martín, Buenos Aires, Argentina

DAVID M. SPERLING, Universidade de São Paulo, São Carlos, São Paulo, Brasil

DENISE FERREIRA DA SILVA, University of British Columbia, Vancouver, Canadá

FLORENCIA SAN MARTIN, California State University, San

Bernardino, Califórnia, Estados Unidos

GILBERTTO PRADO, Universidade de São Paulo, São Paulo, São Paulo, Brasil

GIULIANO OBICl, Universidade Federal Fluminense, Niterói, Rio de Janeiro, Brasil

ISABEL SABINO, Universidade de Lisboa, Lisboa, Portugal JORGE VASCONCELLOS, Universidade Federal Fluminense, Niterói, Rio de Janeiro, Brasil

JOSETTE TRÉPANIÈRE, Université du Québec à Trois-Rivières, Trois-Rivières, Quebec, Canadá

LIGIA DABUL, Universidade Federal Fluminense, Niterói, Rio de Janeiro, Brasil

LUCIA GOUVÊA PIMENTEL, Universidade Federal de Minas

Gerais, Belo Horizonte, Minas Gerais, Brasil

LUIZ CLÁUDIO DA COSTA, Universidade do Estado do Rio de Janeiro, Rio de Janeiro, Rio de Janeiro, Brasil

LUIZ GUILHERME VERGARA, Universidade Federal Fluminense, Niterói, Rio de Janeiro, Brasil

LUIZAN PINHEIRO DA COSTA, Universidade Federal do Pará, Belém, Pará, Brasil

MARCIA SÁ CAVALCANTE SCHUBACK, Södertörn University, Estocolmo, Suécia
MARIA BEATRIZ DE MEDEIROS, Universidade de Brasília, Brasília, Distrito Federal, Brasil

MARIA DE FÁTIMA MORETHY COUTO, Universidade Estadual de Campinas, Campinas, São Paulo, Brasil

MARIA LUISA TÁVORA, Universidade Federal do Rio de Janeiro, Rio de Janeiro, Rio de Janeiro, Brasil

MARIANA PIMENTEL, Universidade do Estado do Rio de Janeiro, Rio de Janeiro, Rio de Janeiro, Brasil

MARTA LUIZA STRAMBI, Universidade Estadual de Campinas,

Campinas, São Paulo, Brasil

MAURICIUS FARINA, Universidade Estadual de Campinas,

Campinas, São Paulo, Brasil

MÔNICA ZIELINSKY, Universidade Federal do Rio Grande do Sul, Porto Alegre, Rio Grande do Sul, Brasil

PAULO KNAUSS, Universidade Federal Fluminense, Niterói, Rio de Janeiro, Brasil

PEDRO HUSSAK, Universidade Federal Rural do Rio de Janeiro, Rio de Janeiro, Rio de Janeiro, Brasil

PEDRO PABLO GOMÉZ, Universidad Distrital Francisco José de Caldas, Bogotá, Colômbia

REGINA MELIM, Universidade do Estado de Santa Catarina, Florianópolis, Santa Catarina, Brasil

SALLY YARD, University of San Diego, San Diego, Califórnia,

Estados Unidos

SHEILA CABO GERALDO, Universidade do Estado do Rio de Janeiro, Rio de Janeiro, Rio de Janeiro, Brasil

Sylvia Furegatti, Universidade Estadual de Campinas, Campinas, São Paulo, Brasil

VIVIANE MATESCO, Universidade Federal Fluminense, Niterói, Rio de Janeiro, Brasil

WALTER D. Mignolo, Duke University, Durham, Carolina do Norte, Estados Unidos 
Adriana Magro, Universidade Federal do Espírito Santo, Vitória, Espírito Santo, Brasil

Almerinda da Silva Lopes, Universidade Federal do Espírito Santo, Vitória, Espírito Santo, Brasil

Ana Maria Albani de Carvalho, Universidade Federal do Rio Grande do Sul, Porto Alegre, Rio Grande do Sul, Brasil Angela Grando, Universidade Federal do Espírito Santo, Vitória, Espírito Santo, Brasil

Aparecido José Cirillo, Universidade Federal do Espírito Santo, Vitória, Espírito Santo, Brasil

Beatriz Pimenta Velloso, Universidade Federal do Rio de Janeiro, Rio de Janeiro, Rio de Janeiro, Brasil

Beatriz Rauscher, Universidade Federal de Uberlândia, Uberlândia, Minas Gerais, Brasil

Camila Monteiro Schenkel, Universidade Federal do Rio Grande do Sul, Porto Alegre, Rio Grande do Sul, Brasil

Carla Luzia de Abreu, Universidade Federal de Goiás, Goiânia, Goiás, Brasil

Carlos Augusto Moreira da Nóbrega, Universidade Federal do Rio de Janeiro, Rio de Janeiro, Rio de Janeiro, Brasil

Carolina Coelho Soares, Universidade de São Paulo, São Paulo, São Paulo, Brasil

Carolina Vanegas Carrasco, Universidad Nacional de San Martín, Buenos Aires, Argentina

Cláudia Leão, Universidade Federal do Pará, Belém, Pará, Brasil

Cayo Vinicius Honorato da Silva, Universidade de Brasília, Brasília, Distrito Federal, Brasil

Daniela Pinheiro Machado Kern, Universidade Federal do Rio Grande do Sul, Porto Alegre, Rio Grande do Sul, Brasil

David Sperling, Universidade de São Paulo, São Carlos, São Paulo, Brasil

Dulce Osinski, Universidade Federal do Paraná, Curitiba, Paraná, Brasil

Elisa de Magalhães, Universidade Federal do Rio de Janeiro, Rio de Janeiro, Rio de Janeiro, Brasil

Fernando Antonio Oliveira Mello, Universidade Federal de Goiás, Goiânia, Goiás, Brasil

Isabela Nascimento Frade, Universidade Federal do Espírito Santo, Vitória, Espírito Santo, Brasil

Ivair Reinaldim, Universidade Federal do Rio de Janeiro, Rio de Janeiro, Rio de Janeiro, Brasil

João Cardoso Palma Filho, Universidade Estadual Paulista, São Paulo, São Paulo, Brasil

Jociele Lampert de Oliveira, Universidade do Estado de Santa Catarina, Florianópolis, Santa Catarina, Brasil

Jorge Luiz Cruz, Universidade do Estado do Rio de Janeiro, Rio de Janeiro, Rio de Janeiro, Brasil 
Kássia Borges, Universidade Federal de Uberlândia, Uberlândia, Minas Gerais, Brasil Lívia Flores, Universidade Federal do Rio de Janeiro, Rio de Janeiro, Rio de Janeiro, Brasil Lucas Pacheco Brum, Universidade Federal de Pelotas, Pelotas, Rio Grande do Sul, Brasil Ludmila de Lima Brandão, Universidade Federal de Mato Grosso, Cuiabá, Mato Grosso, Brasil Luizan Pinheiro, Universidade Federal do Pará, Belém, Pará, Brasil Luiz Cláudio da Costa, Universidade do Estado do Rio de Janeiro, Rio de Janeiro, Rio de Janeiro, Brasil Marcelo Wasem, Universidade Federal do Sul da Bahia, Porto Seguro, Bahia, Brasil

Maria Cristina Fonseca da Silva, Universidade do Estado de Santa Catarina, Florianópolis, Santa Catarina, Brasil Maria de Fátima Morethy Couto, Universidade Estadual de Campinas, Campinas, São Paulo, Brasil Mariana Novaes, Universidade Federal do Sul da Bahia, Porto Seguro, Bahia, Brasil Maria Raquel da Silva Stolf, Universidade do Estado de Santa Catarina, Florianópolis, Santa Catarina, Brasil Marta Strambi, Universidade Estadual de Campinas, Campinas, São Paulo, Brasil Mauricius Farina, Universidade Estadual de Campinas, Campinas, São Paulo, Brasil Mônica Zielinsky, Universidade Federal do Rio Grande do Sul, Porto Alegre, Rio Grande do Sul, Brasil Nara Beatriz Milioli Tutida, Universidade do Estado de Santa Catarina, Florianópolis, Santa Catarina, Brasil Orlando Franco Maneschy, Universidade Federal do Pará, Belém, Pará, Brasil

Paulo Roberto de Oliveira Reis, Universidade Federal do Paraná, Curitiba, Paraná, Brasil Rejane Galvão Coutinho, Universidade Estadual Paulista, São Paulo, São Paulo, Brasil Ricardo Maurício Gonzaga, Universidade Federal do Espírito Santo, Vitória, Espírito Santo, Brasil Rodrigo Guerón, Universidade do Estado do Rio de Janeiro, Rio de Janeiro, Rio de Janeiro, Brasil Rosa María Blanca Cedillo, Universidade Federal de Santa Maria, Santa Maria, Rio Grande do Sul, Brasil Rosangela Cherem, Universidade do Estado de Santa Catarina, Florianópolis, Santa Catarina, Brasil Rubens de Sá Pileggi, Universidade Federal de Goiás, Goiânia, Goiás, Brasil Samuel José Gilbert de Jesus, Universidade Federal de Goiás, Goiânia, Goiás, Brasil Sandra Ramalho, Universidade do Estado de Santa Catarina, Florianópolis, Santa Catarina, Brasil Sheila Cabo Geraldo, Universidade do Estado do Rio de Janeiro, Rio de Janeiro, Rio de Janeiro, Brasil Sylvia Furegatti, Universidade Estadual de Campinas, Campinas, São Paulo, Brasil Tathyane Hofke, Con-tato / Universidade do Estado do Rio de Janeiro, Rio de Janeiro, Rio de Janeiro, Brasil Tatiana da Costa Martins, Universidade Federal do Rio de Janeiro, Rio de Janeiro, Rio de Janeiro, Brasil Teresinha Barachini, Universidade Federal do Rio Grande do Sul, Porto Alegre, Rio Grande do Sul, Brasil Tiago Samuel Bassani, Universidade Federal do Oeste da Bahia, Barreiras, Bahia, Brasil Ubiraélcio da Silva Malheiros, Universidade Federal do Pará, Belém, Pará, Brasil 


\section{REVISÃO ORTOGRÁFICA E NORMATIZAÇÃO}

ALINE CHAGAS DOS SANTOS, Universidade Federal

Fluminense, Niterói, Rio de Janeiro, Brasil

AUGUSTO MELO BRANDÃO, Universidade Federal

Fluminense, Niterói, Rio de Janeiro, Brasil

ESTEFÂNIA YOUNG, Universidade Federal Fluminense, Niterói,

Rio de Janeiro, Brasil

JANDIR JR., Universidade Federal Fluminense, Niterói, Rio de Janeiro, Brasil

JULIA LINDENBERG BRAGA DE THUIN, Universidade Federal

Fluminense, Niterói, Rio de Janeiro, Brasil

LUCAS ALBERTO MIRANDA DE SOUZA, Universidade Federal

Fluminense, Niterói, Rio de Janeiro, Brasil

\section{TRADUÇÃO}

ANA CLARA SILVA MATTOSO, Universidade Federal

Fluminense, Niterói, Rio de Janeiro, Brasil

AUGUSTO MELO BRANDÃO, Universidade Federal

Fluminense, Niterói, Rio de Janeiro, Brasil

\section{DESIGN GRÁFICO E FINALIZAÇÃO}

ANA SAYEG TRANCHESI, Universidade Federal Fluminense, Niterói, Rio de Janeiro, Brasil

LIANA NIGRI MOSZKOWICZ, Universidade Federal

Fluminense, Niterói, Rio de Janeiro, Brasil

\section{COMUNICAÇÃO, DOCUMENTAÇÃO E MEMÓRIA}

BEATRIZ NASCIMENTO TRILES, Universidade Federal

Fluminense, Niterói, Rio de Janeiro, Brasil

BELISA BITENCOURT CUNHA, Universidade Federal

Fluminense, Niterói, Rio de Janeiro, Brasil

RAQUEL TORRÃO VALENTIM, Universidade Federal Fluminense, Niterói, Rio de Janeiro, Brasil

THIGRESA ALMEIDA, Universidade Federal Fluminense, Niterói, Rio de Janeiro, Brasil

Revista Poiésis é uma publicação semestral online do Programa de Pós-Graduação em Estudos Contemporâneos das Artes da Universidade Federal Fluminense. Endereço eletrônico: http://www.periodicos.uff.br/poiesis/

(c) 2022 by PPGCA - É permitida a reprodução total ou parcial do conteúdo desta publicação, desde que para fins não comerciais e que os créditos e referências à publicação e aos/às autores/as sejam preservados. Os trabalhos publicados são de responsabilidade exclusiva de seus/as autores/as, assim como a autorização para a publicação nesta edição das imagens contidas em seus respectivos artigos. Esta publicação é distribuída nos termos da licença Creative Commons; Atribuição: Não Comercial, Sem Derivações - 4.0 Internacional [CC-BY-NC]. 


\section{SUMÁRIO \\ [REVISTA POIÉSIS, V. 23, N. 39, JAN./JUN. 2022]}

\section{EDITORIAL}

DOSSIÊ Dossiê Indigestos Trópicos | Organização: Ana Carolina Prudente Nascimento; Ana Clara Silva Mattoso; Ana Sayeg Tranchesi; Augusto Melo Brandão; Thigresa Almeida

14 Apresentação: Pergunte à Terra | Ana Carolina Prudente Nascimento, Ana Clara Silva Mattoso, Ana Sayeg Tranchesi, Augusto Melo Brandão, Thigresa Almeida [Universidade Federal Fluminense, Brasil]

18 Imagem trans: transe, fabulação e sobrevivências na fronteira | Camila Freitas; José Miguel Olivar

55 A arte brasileira não se resume ao eixo Rio de Janeiro - São Paulo: sotaques poéticos do Nordeste por uma urgente história da arte | Eduardo Bruno; João Paulo Lima; Waldírio Castro

73 Com o que sonha Lula? Krenak sonha com lives | Julia Raiz; Maré

94 Os Baobás do fim do mundo: trechos líricos de uma etnografia com religiões de matriz africana no sul do Rio Grande do Sul | Marília Kosby; José Darci Barros Gonçalves

102 Série Mapas | Talles Lopes

115123 ponteiros de Brasil | Elilson 


\section{PÁGINA DE ARTISTA}

132 Controle de Gênero | Leona Machado

\section{ARTIGOS}

136 Cinzas, cacos e rastros: apontamentos sobre a noção de vestígio | Daidrê Thomas de Amorim

155 Os Objetos gráficos de Mira Schendel: o silêncio da fala na imagem | Thiago Grisolia Fernandes

170 Abraham Palatnik: a luz como meio de expressão plástica | Almerinda da Silva Lopes

187 Imagens em trânsito, poderes e arquivos | Maria Ilda Trigo; Fernanda de Souza Oliveira

205 Casa-Exilio, Palavra-Mapa | Karina Dias e Luciana Ferreira

224 Xamanismo em fotolivros de Claudia Andujar: Yanomami e Amazônia | Ana Carolina Albuquerque de Moraes

253 Consideraciones sobre lo sublime y la poética del movimiento | Mariela Brazón Hernández

278 Imagens-lembrança e identidades no cinema intercultural de Tila Chitunda | Fernanda Mendes de Mendonça 


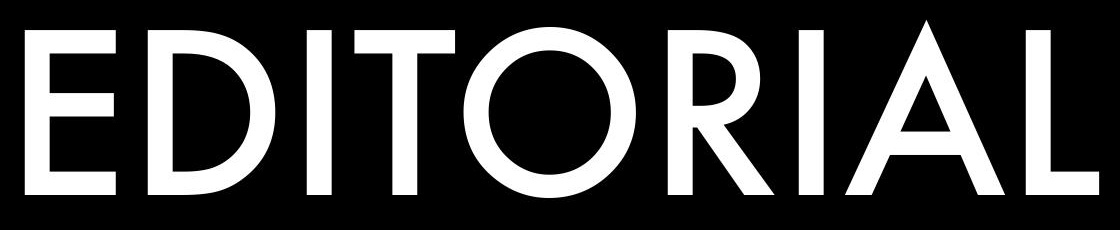


Uma publicação acadêmica no Brasil é absolutamente dependente de processos de colaboração. Com a Revista Poiésis não haveria de ser diferente. A cada edição, publicamos o resultado dos esforços e da participação de muitos colaboradores e colaboradoras (autores, pareceristas, revisores, produtores e diagramadores) que entendem ser o processo editorial acadêmico uma cadeia de participação e de construção coletiva.

Seguindo esta toada, a edição 39 enfatiza essas práticas em uma rede colaborativa construída em torno de seu dossiê central Trópicos indigestos, elaborado e produzido coletivamente por cinco mestrandes e doutorandes do PPGCA-UFF (Ana Carolina, Ana Clara, Ana, Augusto, Thigresa) que, por sua vez, convidaram seis artisties-pesquisadories com a solicitação de que outras redes de colaboração e de trocas fossem ativadas. O resultado é uma enorme teia de participações com desdobramentos que surpreendem nossos horizontes políticos e conceituais, acolhendo trabalhos de Camila, José Miguel, Eduardo, João Paulo, Waldírio, Julia, Maré, Marília, José, Talles e Elilson.

No seguimento da edição, a seção Página de Artista traz a colaboração-arte-pesquisa de Leona, graduande em Artes da UFF, seguida pelos artigos-pesquisa de Thiago, Almerinda, Maria Ilda, Fernanda $\bigcirc$, Karina, Luciana, Ana Carolina, Mariela e Fernanda M, aqui expresses em seus primeiros nomes para lembrar uma necessária coesão no enfrentamento -na condição de sobreviventes que somos-, desses tempos difíceis marcados pelo obscurantismo político e por uma crise sanitária sem precedentes no curso de nossas vidas.

Luiz Sérgio de Oliveira

Editor 


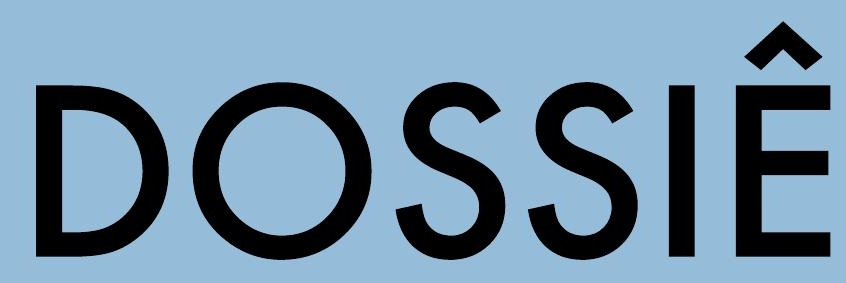

INDIGESTOS TRÓPICOS

ORGANIZAÇÃO: ANA CAROLINA PRUDENTE NASCIMENTO; ANA CLARA MATTOSO;

ANA SAYEG TRANCHESI; AUGUSTO MELO

BRANDÃO; THIGRESA ALMEIDA 


\section{APRESENTAÇÃO: PERGUNTE À TERRA}

Ana Carolina Prudente Nascimento; Ana Clara Mattoso;

Ana Sayeg Tranchesi; Augusto Melo Brandão; Thigresa Almeida

NASCIMENTO, Ana Carolina Prudente; MATTOSO, Ana Clara; TRANCHESI, Ana Sayeg; BRANDÃO, Augusto Melo; ALMEIDA, Thigresa. Pergunte à Terra. Revista Poiésis, Niterói, v. 23, n. 39 , p. 14-17, jan./jun. 2022. [DOI: https:// doi.org/10.22409/ poiesis.v23i39.52940]

Este documento é distribuído nos termos da licença Creative Commons Atribuição - Não Comercial 4.0 Internacional (CC-BY-NC) @ 2022 Ana Carolina Prudente Nascimento; Ana Clara Mattoso; Ana Sayeg Tranchesi; Augusto Melo Brandão e Thigresa Almeida
Indigestão: algo que fica, incomoda; embrulho no estômago, mas também retorno à boca. Necessidade de processar de outra forma. Adesão ao corpo diferenciada, impertinente, no entanto, eficaz em dar notícias sobre transgressão - indigestão não se contém nos limites, é perigosa, precisa transbordar.

Com o título Indigestos Trópicos, o Dossiê da edição 39 da Revista Poiésis visa propor uma reflexão crítica em torno do processo - geográfico, histórico e simbólico - de construção de um discurso da brasilidade. Diante do contexto político e social dos últimos anos, observamos um crescente interesse nas produções de algumes artisties, em questionar não apenas os símbolos da identidade nacional - bandeiras, estandartes e monumentos - como os espaços em que o discurso hegemônico sobre a identidade brasileira se produziu historicamente.

Na contramão do projeto positivista de ordem e progresso emergem práticas políticas e artísticas que denunciam certo estado de indigestão. Da negativa ao banquete conciliatório de uma imagem apaziguadora, esses experimentos parecem querer roer os contornos dos mapas, operando através desse gesto de borramento, novas estórias, imagens e ações. Quem sabe, para perguntar à terra, de suas fendas, de sua fome e de seu grito. 
Indigestos Trópicos apresenta-se assim como uma baliza, não determinante.

No precipício dessas inquietações, decidimos que além de coletiva, nossa indigestão seria também imprevisível. Assim, acionamos um convite-dispositivo a 6 artisties-pesquisadories com a seguinte proposta performativa:

\section{Convide outra pessoa, de sua livre escolha, para realizar com ela seu trabalho;}

2. A forma e o conteúdo são livres, mas a proposta, seja ela qual for, deve surgir do encontro de vocês, em coautoria;

3. Pedimos que, sempre que possível, levem em consideração o formato da revista, que não comporta vídeos, apenas imagens e textos.

Fosse através de um trabalho visual, um ensaio, um texto literário ou o que mais Ihes apetecesse, nossa proposição fundamentava-se no desejo de incrementar com dissonância uma receita intuitiva de curadoria aberta. Não sabíamos, naquele momento, que o acaso direcionado traria consigo contribuições tão pulsantes sobre transversalidade, fronteiras, imaginários sonhados-cruzados, e fricções entre a História contada e as estórias desviantes. Fabular o presente para sonhar com futuros mais possiveis e alegres para todes.
Os trópicos podem ser enfim remodelados em margens fluídas, vibrantes e furtivas, configurando resistências abrigadas em comunalidades e comunidades transitórias, espaços onde a borda invade o centro, e o centro se espalha sem retorno. Aqui, falamos de uma contra-exterioridade daquela produzida pelo que se convenceu chamar de centro. A borda produz, quebra e reorganiza os olhares. Desde a borda pensamos e articulamos este Dossiê. Desde o seu lugar da contra-exterioridade disparamos um gatilho: produzir uma dissonância no centro.

Depois de organizar, reorganizar estas ordens, de entender na prática, nas escritas, nas fotografias e relatos os Indigestos Trópicos, o que se configurava como uma provocação, um gatilho e até mesmo uma baliza, transfere-se para uma ação. Corpus Indigestos Trópicos, conceito Indigestos Trópicos, performance e ação Indigestos Trópicos.

Pensar neste dispositivo convidativo de produção para este trabalho de curadoria proporcionou que cada trabalho presente formasse sua própria teia com outres sujeitos, sejam pelas centenas de vozes que foram ouvidas pelo artista, professor e pesquisador Elilson e transmitidas em seu trabalho 123 ponteiros de Brasil; ou seja pela presença dos artistas fortalezenses Ednardo e Augusto Pontes; da artista cearense que nasceu no distrito de Quitaiús do município de Lavras da Mangabeira-CE, Maria 
Macedo; do artista da região do sertão do Ceará, Lívio Pereira ou escritor cearense,Thiago Florêncio, que foram presentificados no texto A arte brasileira não se resume ao eixo Rio de Janeiro - São Paulo: sotaques poéticos do Nordeste por uma urgente história da arte escrito às seis mãos de Eduardo Bruno, João Paulo Lima e Waldírio Castro.

Ou ainda, nas localidades e nas imagens dos trabaIhos Os Baobás do fim do mundo: trechos líricos de uma etnografia com religiões de matriz africana no sul do Rio Grande do Sul de Marília Kosby e Zé Darci e na Série Mapas de Talles Lopes, assim como os atravessamentos entre cinema e etnografia, embalados pelo tambor da macumba no texto de Camila Freitas e José Miguel Olivar.

Nesse sentido, Imagens trans: transe, fabulação e sobrevivências na fronteira, é encruzilhada na floresta, dando início as contribuições do dossiê com texto partilhado por Camila Freitas e José Miguel Olivar. Contextualizado na Tríplice Fronteira Amazônica entre Brasil, Peru e Equador, o "entre" é o elo fundamental para se orientar frente às experiências de corpos dissidentes em um território transfronteiriço-sempre em trânsito. Habitar a fronteira ecoa como aposta do encontro entre cineasta e antropólogo, nos alcançando com imagens-vagalumes de um tempo além do tempo.
Nossa bússola sem norte segue adiante nos levando até o enlace entre Eduardo Bruno, João Paulo Lima e Waldírio Castro, um texto-labirinto para repensar as produções deslocalizadas do sudeste a partir de outras localidades geográficas, históricas e simbólicas. A arte brasileira não se resume ao eixo Rio de Janeiro - São Paulo se estabelece perante a urgência de se produzir outras trajetórias para compreender o fazer da performance. Re-pensar a arte brasileira, os fazeres artísticos desde outros poros e porosidades que podem e vão expandir olhares das formas de contar a performance em seus dissensos brasilis.

Na sequência, trombamos com Julia Raiz e Maré em uma especulação futurista denominada: Com o que sonha Lula? Krenak sonha com lives. Sonha-se sonhos úmidos, sonhos de terra, de hormônios e formigas, o que é profundo e perpassa todas as existências - mesmo a das bisas em suas vidas aparentemente pacatas. Assim segue o baile, a prosa, o poema-experimento que provoca os os sentidos, imbrica imagens, panos de bandeira em um certo sarcasmo, elemento imprescindível a toda receita indigesta.

Numa reverberação não programada dos últimos trechos de Raiz e Maré, seguimos em outra parceria, dessa vez de Marília Kosby e José Darci Barros Gonçalves com Os Baobás do fim do mundo: 
trechos líricos de uma etnografia com religiões de matriz africana no sul do Rio Grande do Sul. Entretecidos em poemas e pinturas, o axé é materializado em caminhos plurais, apontando direções singulares e ainda assim coletivas.

Talles Lopes, com sua Série Mapas, torna quase tátil a experiência de fronteiras insubordinadas que desejávamos evocar no Dossiê. Não à toa, um de seus trabalhos, A Marcha (2018), foi escolhido como capa da Revista, onde nos inclinamos ao método cartográfico a partir de uma perspectiva confusa. As métricas seguidas pelo artista não se sujeitam a um olhar óbvio. No miolo de nosso Dossiê, já chegando ao fim das contribuições, chegamos ao ensaio visual de Talles, onde outros mapas nos convidam a distorcer as concepções tortas de um Brasil inventado. Em seus mapas, as linhas institucionalizadas da cartografia ocidental, já não são tão rígidas e inquestionáveis.

123 ponteiros incrementam nosso caldo com o tempero final, pois se antes pensávamos numa colaboração em dupla, Elilson traz à dança 123 vozes, coletando-as e colocando em movimento o passado de 123 anos de Juquery, complexo hospitalar e colônia psiquiátrica de São Paulo. A memória é viva, assim como as composições coletivas. Ao frisar o caráter da escuta em seu trabalho - no qual os relatos foram coletados a partir da oralidade - Elilson brinca com um cinema de voz, onde a contação de histórias pode criar novas imagens para estórias já esboroadas pelo tempo.

Assim fluímos, sentindo-nos também parte, participantes de uma rede costurada a muitas mãos, ouvidos, bocas e línguas. Olhares vastos para territórios de caminhadas infinitas. Nunca se esgotam. Lembrete para seguirmos atentes aos murmúrios do solo, ao que está acontecendo agora nas fendas insurgentes de um trópico amargo. Atentes às práticas artísticas engajadas num fazer partilhado, fazer este que ensaia metodologias experimentais abertas ao imprevisível. Nosso palpite é que doses homeopáticas - ou overdoses em alguns casos, quem sabe - de indisciplina, são capazes de, ao menos, transformar o indigesto em um motivo de reconhecimento de pares; reunião daqueles que seguirão conosco nas lutas por terras mais habitáveis e que celebram a possibilidade de traçar, juntes, outras formas de experimentar fronteiras.

NASCIMENTO, A. C. P.; MATTOSO, A. C.; TRANCHESI, A. S.; BRANDÃO, A. M.; ALMEIDA, T. Apresentação: Pergunte à Terra. 


\section{IMAGEM TRANS : TRANSE, FABULAÇÃO E SOBREVIVÊNCIAS NA FRONTEIRA}

trans image: trance, fabulation and survival at the borderland

imagen trans: transe, fabulación y sobrevivencias en la frontera

> Camila Freitas [Universidade Federal do Rio de Janeiro, Brasil] * José Miguel Olivar [Universidade de São Paulo, Brasil] **

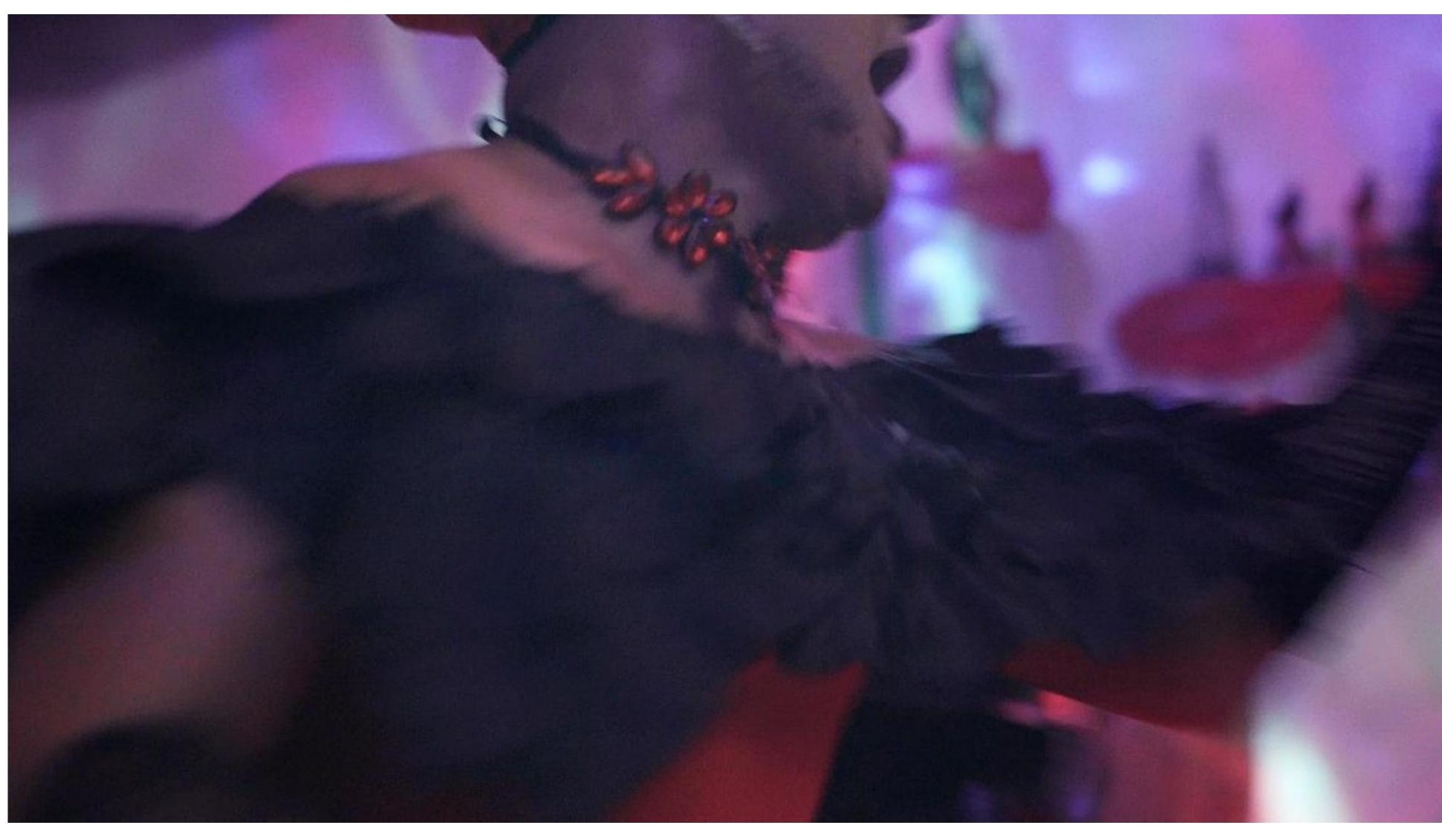


Fig. 1 [página anterior] - Camila Freitas e João Vieira Torres, BABADO, longa-metragem em desenvolvimento, 2022.
FREITAS, Camila; OLIVAR, José Miguel. imagem trans: transe, fabulação e sobre vivências na fronteira. Revista Poiésis, Niterói, v. 23, n. 39 ,

p. 18-54, jan./jun. 2022. [DOI: https:// doi.org/10.22409/ poiesis.v23i39.52941]

Este documento é distribuído nos termos da licença Creative Commons AtribuiçãoNão Comercial 4.0 Internacional (CC-BYNC) (c) 2022 Camila Freitas e José Miguel Olivar.
RESUMO Em uma encruzilhada de confluências e divergências entre cinema, antropologia e artes visuais, o objeto deste texto se articula com o desenvolvimento de um longa-metragem sobre a rede de filhos e filhas de santo e o terreiro do Pai Jairo, e a fronteira na cidade de Tabatinga (AM), entre Brasil, Peru e Colômbia. Temos como base uma experiência híbrida de pesquisa junto à rede de jovens gays e trans atuantes na produção local de Umbanda mais ou menos próximos do mercado do sexo nesta tríplice fronteira. Apostamos nas potências da imagem e do ato narrativo e fabulativo enquanto chaves para habitar e transitar por mundos hostis e fazer emergir contrapoderes para transformar o real. O território especulativo ocupa um lugar especial na criação de mundos dessa rede, e os espaços de partilha narrativa marcam o seu cotidiano. Os nossos encontros com ela são atravessados pelas performances narrativas das jovens e de suas entidades companheiras. Com base nessas interações, pudemos também inventar e propor dispositivos metodológicos de "contação de estórias". Para sustentar nossas análises, apresentamos aqui algumas das muitas sequências narrativas íntimas que emergiram desses encontros. PALAVRAS-CHAVE Umbanda; juventude; contação de histórias; Amazônia; gênero; fronteira; sobrevivência

*Camila Freitas é mestranda em Linguagens Visuais pela Escola de Belas Artes da UFRJ.

E-mail: camilasfreitas@gmail.com. Orcid: 0000-0002-5963-8944

* *José Miguel Olivar é doutor em antropologia social e professor nas áreas de antropologia, gênero e sexualidade, e estudos sociais da ciência e da técnica na Faculdade de Saúde Pública da Universidade de São Paulo.

E-mail: jose-miguel@usp.br. Orcid: 0000-0002-7648-7009

FREITAS, Camila; OLIVAR, José Miguel. imagem trans: transe, fabulação e sobre vivências na fronteira. 
ABSTRACT At a crossroads of confluences and divergences between cinema, anthropology and visual arts, the objective of this text is articulated with the development of a feature film on the network of sons and daughters of santo and the terreiro of Pai Jairo, and the border in the city of Tabatinga (AM) -between Brazil, Peru and Colombia. We are based on a hybrid experience of research with the network of young gays and trans people acting in the local production of Umbanda and more or less engaged with the sexual markets in this triple border. We bet on the power of the image, the narrative and fabulation act as keys to inhabit and transit through hostile worlds and make counterpowers emerge to transform the real. The speculative territory occupies a special place in the creation of worlds of this network, and the spaces of narrative communion mark its ordinary. Our encounters with this network are traversed by the narrative performances of the young participants and their companion entities. Based on these interactions, we were also able to invent and propose methodological devices for storytelling. To support our analysis, we present here some of the many intimate narrative sequences that emerged from these encounters.

KEYWORDS Umbanda; youth; storytelling; Amazon; gender; border; survival

RESUMEN En una encrucijada de confluencias y divergencias entre el cinema, la antropología y las artes visuales, el objetivo de este texto se articula con el desarrollo de un largometraje sobre la red de hijos e hijas de santo y el terreiro de Pai Jairo, y la frontera en la ciudad de Tabatinga (AM), entre Brasil, Peru y Colombia. Tenemos como base una experiencia híbrida de investigación junto a la red de jóvenes gays y trans actuantes en la producción local de la Umbanda y más o menos cercanos a los mercados sexuales en esta triple frontera. Apostamos en las potencias de la imagen y del acto narrativo y fabulativo como llaves para habitar y transitar por mundos hostiles y hacer emerger contrapoderes para transformar lo real. El territorio especulativo ocupa un lugar especial en la creación de mundos de esta red, y los espacios de comunión narrativa marcan su cotidiano. Nuestros encuentros con esta red son atravesados por las performances narrativas de las jóvenes y de sus entidades compañeras. Con base en estas interacciones, pudimos también inventar y proponer dispositivos metodológicos para contar historias. Para dar soporte a nuestro análisis, presentamos aquí algunas de las muchas secuencias narrativas íntimas que emergieron de estos encuentros.

PALABRAS CLAVE Umbanda; juventud; contar historias; Amazonía; género; frontera; supervivencia 
Su cuerpo es una bocacalle. [Anzaldúa,2012[1987]]: 80]

Sobrevida não é apenas aquilo que resta, ela é a vida mais intensa possível.

[DERRIDA, 2005, p. 55-56]

Les images sont trans-genre, queer parfois, transgénériques toujours. [MONDZAIN, 2012, p. 101$]$

\section{MACUMBA, CRESCIMENTO E SOBREVIVÊNCIA: QUINHO/TILINHA}

Certa noite, Quinho teve um sonho com uma mulher loira e alta em uma encruzilhada. Ela Ihe apresentava dois caminhos: um limpo e outro cheio de espinhos. No sonho, ela escolheu o caminho mais difícil. Na época, havia perdido a mãe e passava por um longo processo depressivo. Sua família repudiava o fato de Quinho ser uma mulher trans e a renegou. Uma tia que vivia em Manaus convidou- a a morar com ela. Preocupada com seu estado psicológico, apresentou-lhe um hospital espírita. A partir dali, Quinho foi também apresentada a um terreiro de Umbanda, onde teve contato com caboclos e erês, pombagiras e exus. Em uma de suas idas iniciais a um terreiro, conheceu Jairo, que também vivia em Manaus naquele momento e começava a se iniciar como pai de santo. Lá mesmo, tomou a decisão de acompanhá-lo, tornando-se uma de suas primeiras filhas de santo.

Antes da macumba', Quinho - apelido que recebera da mãe quando criança - foi evangélica e adorava a igreja. Em um dos primeiros encontros que fizemos para a realização do filme Babado [ver nota \#9], pediu para falar para a câmera sobre um episódio violento que marcou sua infância e se interpôs entre ela e a fé cristã. Sua mãe tinha uma relação próxima com o pastor, que chamava o então Ely de 10 anos para brincar com seus filhos em casa. Quinho recebia visitas noturnas do sacerdote, que o pastor dizia serem ordenadas por Deus. Os estupros se prolongaram por mais ou menos dois anos. O menino não queria voltar àquela casa, mas a mãe o obrigava. Quando finalmente tomou coragem para relatar o acontecido, ninguém acreditou; apenas um tio decidiu averiguar os fatos. Após confirmação, toda a igreja soube, mas o caso foi abafado. Sua mãe finalmente o acolheu, conferindo-Ihe proteção. Quando ela faleceu, no entanto, Quinho já havia feito sua transição, e a família a renegou: os irmãos, após o enterro, barraram sua entrada em casa.

Em Manaus, encantada com suas amigas "travas" lindas e maravilhosas, Quinho "se libertou" e se 
descobriu travesti. Em função de sua irmã mais velha, a Tila, também uma mulher trans, ganhou o nome de Tilinha. A prostituição era o meio de vida da maioria das amigas que, como ela, vinha do interior para crescer e tentar a vida na capital. Ela tentou, mas não gostou, e faz questão de marcar uma posição diferenciada em relação à maioria das pessoas de seu círculo. Quinho escolheu a outra profissão mais comum para as mulheres trans da região: cabeleireira.

Dona Tatá, a pombagira ${ }^{2}$ na cabeça de Quinho - a mulher bonita do sonho -, também transita pela

rua, pela putaria, pela encruzilhada e pela calunga ${ }^{3}$. "Uma vez, vi uma senhora num cemitério. Depois, numa gira, incorporei, e Dona Tatá disse que tinha me visto e me chamado no cemitério." Outra vez, fez um trabaIho [de macumba] para conseguir um trabalho [na vida],

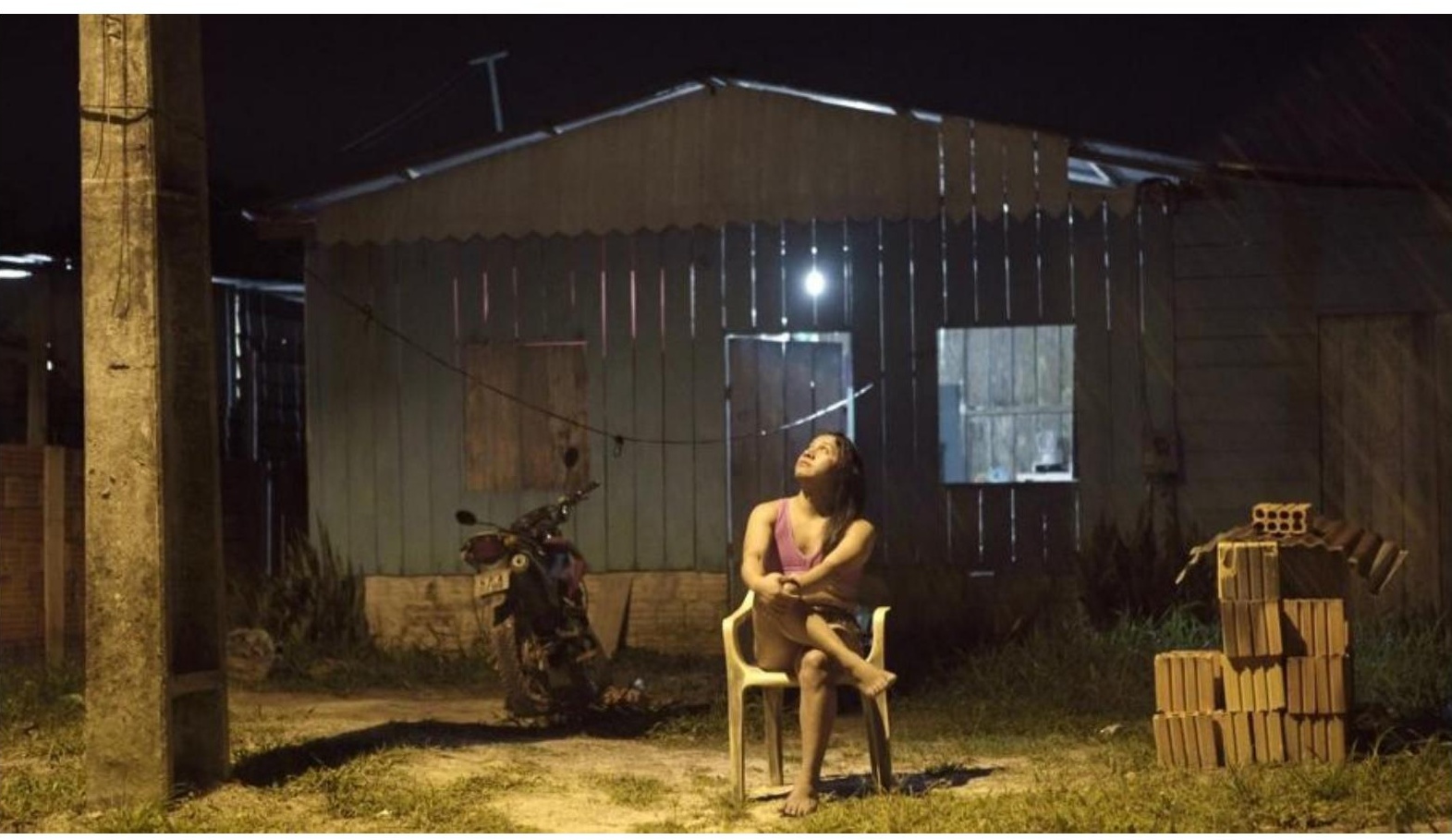

Fig. 2 - Camila Freitas e João Vieira Torres, BABADO, longa-metragem em desenvolvimento, 2022. porém não pagou a obrigação e logo foi demitida. Deu de comer à sua pombagira e foi recontratada em seguida. Para agradar a sua senhora, oferece- Ihe champanhe, maçã, velas: "quando se agrada a Exu4 , Exu é riqueza, Exu é força", ela diz. "Exu é temperamental, com ele não se brinca e nem se bate cabeça, tampouco se abaixa a cabeça". As leis de Exu são as leis da rua. Medo, não; respeito.

Exu é moço Branco/E é faceiro no andar/

Quem não paga pra Exu/ Exu dá e torna a tirar. ${ }^{5}$

Revista Poiésis, Niterói, v. 23, n. 39, p. 18-54, jan./jun. 2022. [DOl: https://doi.org/10.22409/poiesis.v23i39.52941] 
INTRODUÇÃO: IMAGENS EM REDE

Desenvolvemos este trabalho a partir de uma experiência híbrida de pesquisa junto a uma rede de jovens gays e trans atuantes na produção local de Umbanda e mais ou menos próximos do mercado do sexo na Tríplice Fronteira amazônica, entre Brasil, Peru e Colômbia. ${ }^{6}$ Nele, apostamos nas potências da imageme do ato narrativo e fabulativo enquanto chaves para habitar e transitar por mundos hostis e fazer emergir, "no extracampo da ordem dominante", os contrapoderes a partir dos quais se pode transformar o real [MONDZAIN, 2012, p. 101].

Inicialmente atravessada pela rua e pela intensidade dos mergulhos quase diários das gays ${ }^{7}$ na noite da Fronteira - em busca de encontros, álcool, curtição, sexo e dinheiro -, a etnografia de José Miguel Olivar ${ }^{8}$, base desta experiência, passou aos poucos a ser afetada pela macumba, na medida em que seus rituais e gestos passaram a compor uma "espiritualidade" e, com ela, a ocupar cada vez mais espaço nas vidas/corpos dessa rede, em suas cabeças e noites.

Em uma encruzilhada de confluências e divergências entre cinema, antropologia e artes visuais, o objeto deste texto se articula com o processo de desenvolvimento de um longa-metragem' sobre a fronteira, a rede de filhos e filhas de santo e o terreiro de Jairo. O terreiro é o chão, o assentamento material e o nó da encruzilhada cosmopolítica ${ }^{10}$ a partir da qual cresce e floresce essa rede "muito jovem e muito gay"11 entre a macumba, as sexualidades intensivas e as múltiplas fronteiras, entre a rua e a rua, a noite e a noite, a fluidez e a contraefetuação das normas de gênero-e-sexualidade.

O território especulativo e suas potencialidades ocupam um lugar especial na criação de mundos dessa rede, e os espaços de partilha narrativa marcam o seu cotidiano. Os nossos encontros com elas, incluindo os momentos após as giras no terreiro, são atravessados pelas performances narrativas das gays e de suas entidades companheiras, que nos dispomos a presenciar como ouvintes participativos. Com base nessas interações, pudemos também inventar e propor dispositivos narrativos - durante as filmagens e em encontros que chamamos de oficinas de "contação de estórias". ${ }^{2}$ Esses dispositivos eram, de forma geral, menos propensos a documentar estórias individuais do que criar um tipo de escrita performativa e coletiva, na efervescência da oralidade e na presença da câmera, em um certo dispositivo "mediúnico" em que umas emprestam seus corpos e vozes para contar as estórias das outras. ${ }^{13}$ Apresentamos aqui algumas das muitas sequências narrativas íntimas que emergiram desses encontros. 

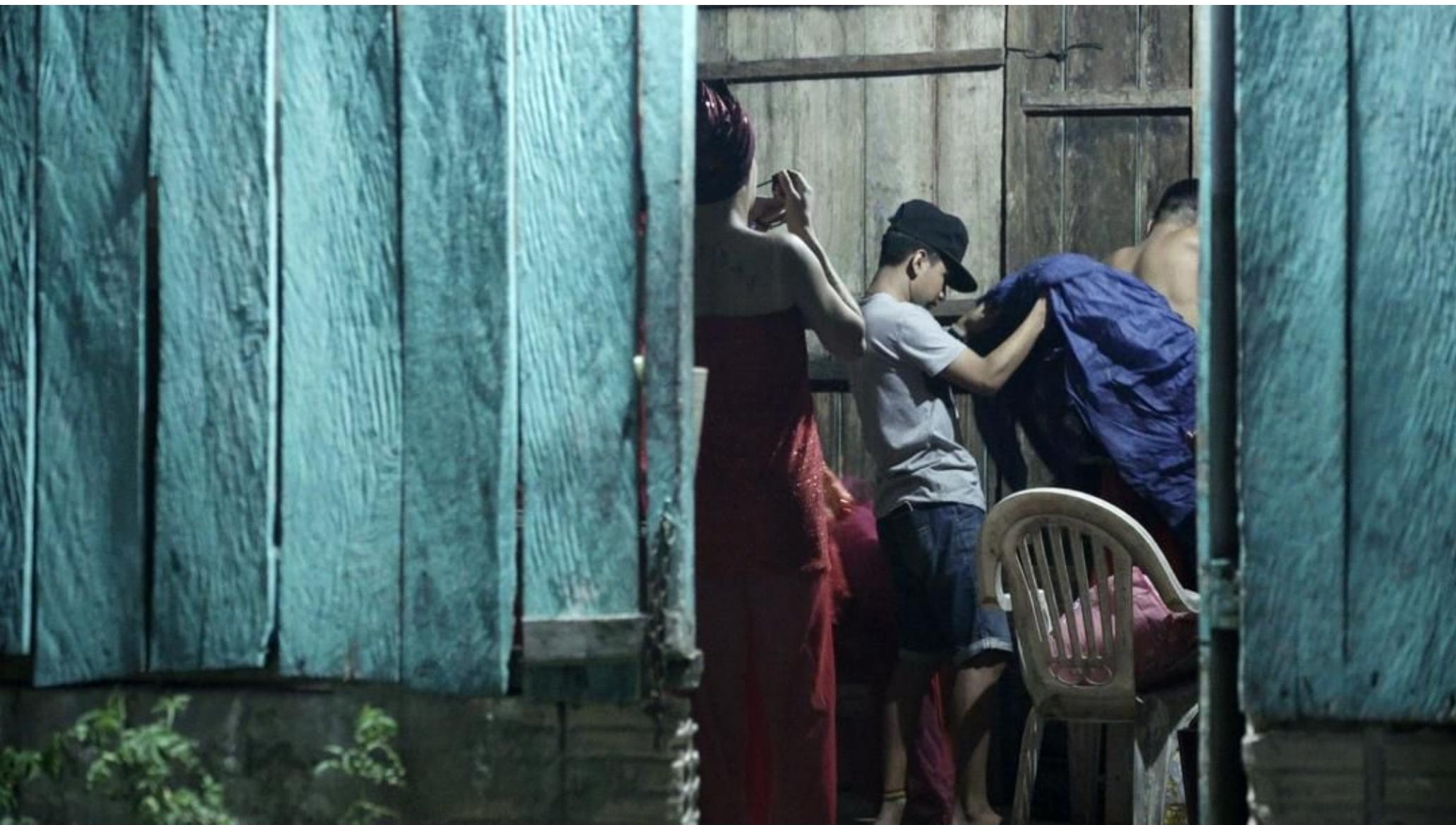

Fig. 3 - Camila Freitas e João Vieira Torres, BABADO, longa-metragem em desenvolvimento, 2022.

A partir do conjunto dessas imagens fixas e audiovisuais, cuja matéria-prima principal é uma tessitura de estórias e performances entremeadas com a dinâmica do terreiro, da noite e da rua, refletimos sobre o estatuto da imagem e sua produção, inseparável de gestos de tomada de posição e transformação política que nos conectam em rede. Com essas imagens, que pensamos então como imagens trans, refletimos sobre dispositivos de narrativização, fabulação e outras produções estéticas e performativas capazes de tecer alianças, redes e familiaridades ${ }^{14}$ entre existências que, desde a diferença, persistem contra-ameaças e perigos constantes. 


\section{ESCURIDÃO COMO POTÊNCIA: TATA MOLAMBO}

Durante uma gira "de esquerda", em uma pausa do tambor, várias pombagiras estavam sentadas, bebendo, após horas de cantos e giros no salão. Seu Tatá Caveira, um exu incorporado por pai Jairo, raIhou com elas dizendo que, se não se levantassem, fecharia logo o tambor: "pombagira é povo da rua, que anda a noite toda". Incisivo, instou dona Tatá Molambo, na cabeça de Quinho, a puxar um ponto. Tatá cantou, com o entusiasmo que the é peculiar, acompanhada dos tambores dos ogãs:

\section{Diabo está no inferno, a pombagira está no congá/ Cuidado Macho safado que eu posso te matar. ${ }^{15}$}

Após a gira, Tatá Molambo conversou conosco e com a câmera. Entre muitas baforadas de charuto, iniciou a conversa afirmando que andou muito na escuridão, e que esse foi o seu melhor caminho. A escuridão é, em suas palavras, o que lhe confere força para ser uma mulher guerreira. Tatá nasceu na Espanha, filha única de pais ricos.

Fig. 4 - Camila Freitas e João Vieira Torres, BABADO, longa-metragem em desenvolvimento, 2022.
Quando moça, se apaixonou por um camponês que trabalhava no castelo da família, para o desgosto de seus pais. Ela amou esse homem como ninguém, mas ele a deixou. Triste por ter perdido a única felicidade que já tivera, terminou mergulhando na noite e passou a andar de cabaré em cabaré para buscar o seu amor. Um dia, ela o encontrou num bordel com muitas mulheres e tentou levá-lo embora. $\bigcirc$ ex-amante a embriagou, a seguiu e terminou enterrando-a viva, ébria.

O homem que ela amava a matou. Durante sua vida em Terra, não encontrou felicidade. Ogum, patrão de Exu, fez com que ela voltasse como pombagira e, uma vez assim, Tatá passou a gostar de frequentar cabarés de luxo. Apesar de todo infortúnio, seu caminho foi marcado pelo amor.
Eu amei alguém, mas esse alguém não ama ninguém

Eu amei o sol, eu amei a lua, na encruzilhada eu amei Seu Tranca-Rua. ${ }^{16}$ 
TERREIRO-FRONTEIRA: ESPAÇO

NARRATIVO [IN]COMUM

A casa de Jairo habilita a existência do terreiro, da macumba e da rede, a partir de onde se produz uma experiência particular dessa Tríplice Fronteira e da Amazônia como Fronteira, em meio a seus complexos processos de normatização, militarização, mobilidade, circulação de pessoas, dinheiro e tráfico [OLIVAR, 2019]. Ali e desde ali, médiuns, pai e filhos de santo coabitam os espaços de dentro [a casa, a seara, o congá, o corpo, a intimidade] e fora [a rua, a noite, o close ${ }^{17}$, o cemitério, a encruzilhada, a Fronteira]. Parte integrante dos ritos religiosos da Umbanda e do Tambor de Mina praticados ali, a partilha - de experiências, aprendizados, alegrias, violências, durezas, feitiçarias e receitas de resistência ${ }^{18}$ - é um aspecto constitutivo desse terreiro e dessa rede.

Ao final dos rituais, uma vez o tambor fechado e a gira oficialmente terminada, todos se reúnem em

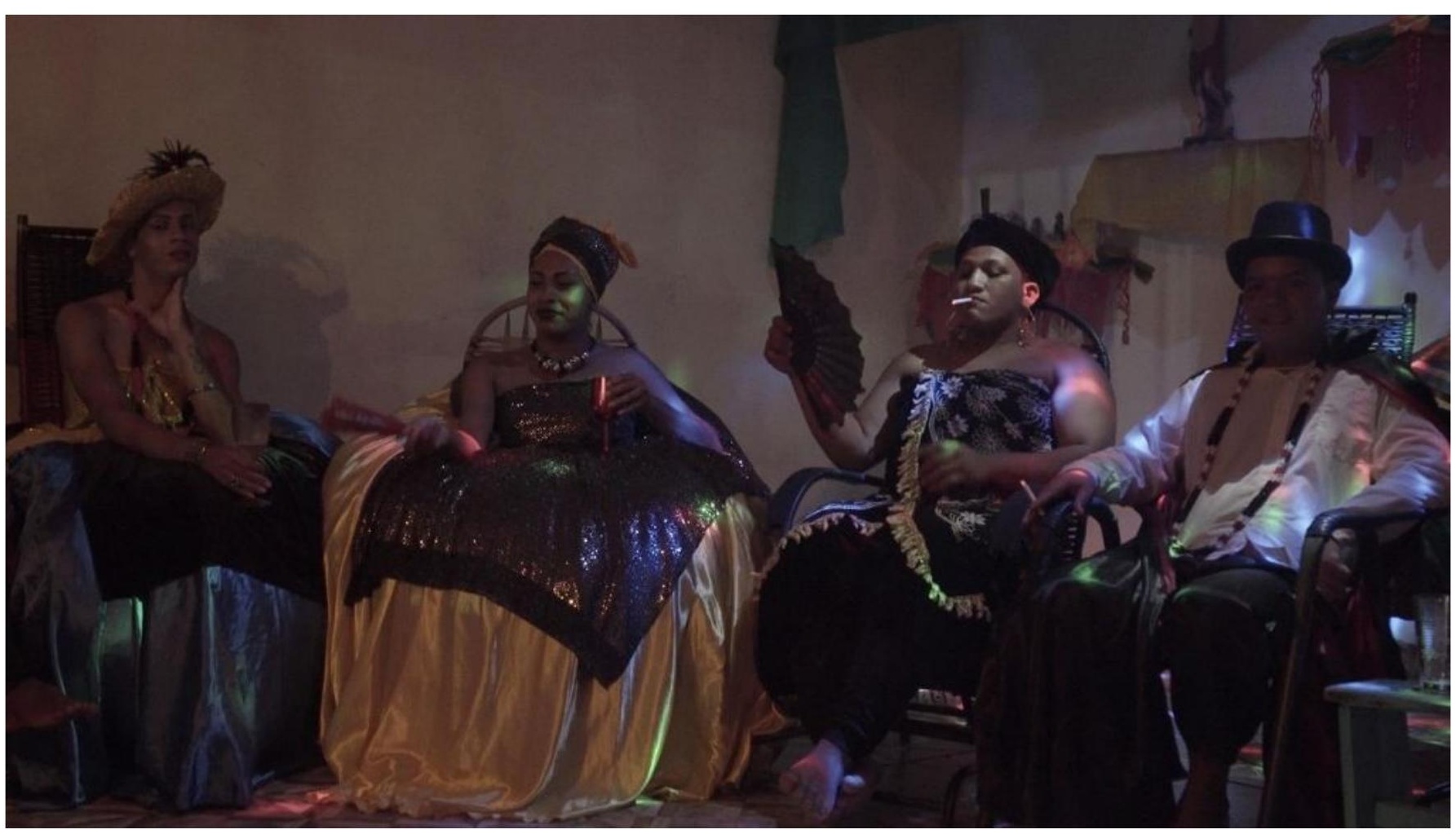

Fig. 5 - Camila Freitas e João Vieira Torres, BABADO, longa-metragem em desenvolvimento, 2022.

Revista Poiésis, Niterói, v. 23, n. 39, p. 18-54, jan./jun. 2022. [DOl: https://doi.org/10.22409/polesis.v23i39.52941] 


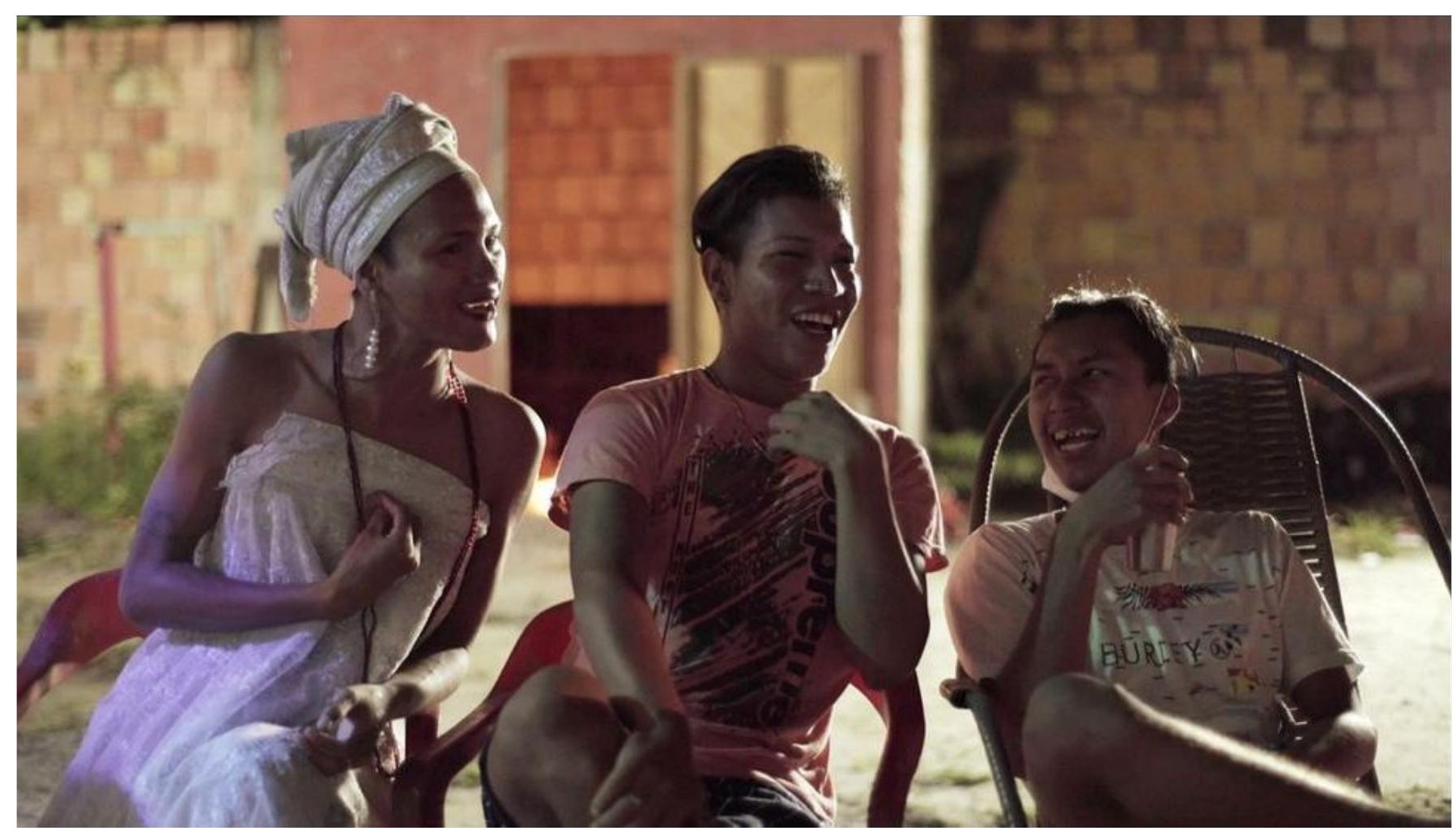

Fig. 6 - Camila Freitas e João Vieira Torres, BABADO, longa-metragem em desenvolvimento, 2022.

roda para beber e papear, seguir trocando conseIhos, causos, piadas ou sermões, fazer consultas informais e batalhas de pontos entre pombagiras, filhos de santo e assistência, "tudo junto e misturado". Ali se pode falar virtualmente de tudo, dos fundamentos da religião até os mais diversos assuntos da vida e do cotidiano, em um clima de embate jocoso e pleno de zoeira, sarcasmo e obscenidades que envolvem a personalidade de várias das entidades do povo da rua. Em certos momentos e FREITAS, Camila; OLIVAR, José Miquel. imagem trans: transe, fabulação relações, as fronteiras hierárquicas e carnal-espirituais parecem bastante fluidas.

Ao se perguntar sobre o papel das narrativas na materialização dos espíritos enquanto sujeitos, na medida em que eles são, no imaginário e na prática cotidiana da macumba, ao mesmo tempo objetos e sujeitos das estórias que contam, Vânia Zikán Cardoso reflete sobre a emergência do sujeito narrador como um efeito da própria performance. ${ }^{19}$ Os conhecimentos e poderes compar- 
tilhados pelas entidades, suas histórias de vida e identidades, não são reveladas e sistematizadas de forma unificada, mas compõem um "narrar ao mesmo tempo disperso e coletivo" [CARDOSO, 2007a, p. 201] de estórias de vidas, continuamente narradas e recontadas pelos filhos e filhas de santo e assistência. Essa "narrativa em performance" [CARDOSO, 2007b, p. 208], sua partilha e reconhecimento pela rede macumbeira, é o que constitui as entidades enquanto "diversas formas de sujeitos", que podemos entender, junto com a autora, como "diversos modos de experienciare de estar no mundo" [CARDOSO, 2007b, p. 207].

A ideia de performatividade - enquanto ação da linguagem sobre o mundo e invenção de "ficções vivas que permitem resistir à norma"20 [PRECIADO, 2019, p. 97] - se afirma entre os membros dessa rede de forma bastante fluida e horizontal. Narrar aqui é narrar-com, narrar em rede, inventar, lidar com o Mundo, e se afirma como instrumento para tecer alianças entre ideias, entre estórias e palavras, entre ontologias e diversos. O terreiro constitui um espaço [in]comum de narrativização ${ }^{21}$ que se produz através do ritual e reverbera para além dele, desde onde se fabulam, se contam e se cantam dissidências e sobrevivências para caminhar pelo Mundo-como-Ameaça e para criar e transformar outros mundos possíveis [mundo-pra-nós]. ${ }^{22}$
Nos trânsitos fabulativos entre vida e transe, o assunto da violência está sempre latente - seja ela sob a forma da violência urbana associada com reconfigurações recentes do tráfico translocal de drogas, seja a violência de gênero-e-sexualidade que permeia a maioria das trajetórias das gays e, ainda, que perpassa as narrativas "biográficas" das pombagiras. Dentro dessa rede, não há uma "naturalização" de fortes ou dramáticas violências; não se lida com a violência bruta como algo "normal"; no entanto, ela faz parte da vida de múltiplas formas e permeia o ordinário como marcas de [quase] extraordinariedade [DAS, 2007]. A violência se encara, se atravessa, se pratica, se compreende e se traduz nas linguagens disponíveis do cotidiano - da homofobia ao narcotráfico, passando pela cosmopolítica da Umbanda. Na contramão da assepsia burguesa em que "a morte é cada vez mais expulsa do mundo dos vivos", o que se percebe aqui é uma onipresença de fatos violentos e suas narrativizações, que pode ser pensada como forma de reivindicar agência sobre eles, ou ainda, de recuperar a autoridade narrativa que "mesmo um pobre diabo possui ao morrer" e que, segundo Benjamin, está "na origem da narrativa" [BENJAMIN, 1987 [1936], p. 207]. 


\section{BELEZA, NOITE E PUTARIA IRRADIADAS: CRIS}

Cristielly habita este mundo na corporalidade mediúnica feminina que sonha com um corpo em São Paulo - implantes de silicone e possíveis cirurgias que ela espera alcançar um dia - e com o espectro fabulativo de uma maternidade uterina. ${ }^{23}$ Hoje, na casa dos 30, segue sendo uma referência transfronteiriça de beleza trans e continua intensamente engajada no mercado sexual de Tabatinga. Cris é uma "moça de família", muito conectada à sua irmã mais velha, Eliane, e à sua mãe, que ela teme deixar sozinha. Por essa razão, cris até hoje não migrou para "tentar a vida" em Manaus, em São Paulo ou no Peru - caminho corriqueiro para as putas da Fronteira, trilhado por tantas outras amigas e parentes.

Muitas meninas trans de sua geração foram renegadas pela família; a mãe de Cris, ao contrário, sempre a defendeu e protegeu em sua reelaboração de gênero, por volta de seus 14 anos, diante de um pai que abandonou a família na recusa de conviver com o que ele próprio denominou "uma aberração".

Em contraste com a figura do pai "de carne", violento e ausente, Cris prefere pensar em pai Jairo como "o seu pai de verdade". Ela é uma de suas filhas de santo mais antigas: começou a "desenvolver o santo" em 2011 no terreiro ainda em formação e sem assentamento material fixo, o que só se deu em 2013. Conheceu pai Jairo em sua "fase travesti", quando ele ainda era Hannah, "a 'ploc'24 que agora só baixa uma vez por ano na parada gay".

Na religião, para aqueles que nasceram em corpo de homem, é obrigatório usar cueca e roupas masculinas durante os rituais, mas ela não se sente bem e desvia essa regra: "o pai libera, ele é babado...". Cris fala do terreiro como lugar de acolhida e identificação, de onde emergem outras noções de família:

\section{Ele foi meu porto seguro, ele me acolheu [...]. Todos nós fomos acolhidas pela Umbanda e pelo terreiro... Ele me deu força em tudo. Zoro, Alisson, Quinho, iá eram filhos do pai [...]. Eu era visitante, bebia com os caboclos, mas eu falava mal. Eu ia por curiosidade, aí uma vez comecei a me sentir mal, tremer, tremer... saí na carreira, mas não consegui fugir. Veio a cabocla Jacira, eles pensaram que era Jandira... [...]A girou pra esquerda, e de novo... Dama da Noite. Ela nasceu meia noite, na Festa das Dores [...]. Eu amo a minha religião. Mamãe foi crente, eu também... só que não prestou ${ }^{25}$}

Agora, já há quase uma década, ela compreende a sua existência no mundo como constantemente acompanhada - irradiada - pela entidade que Ihe faz frente. Deslizando pela noite feito vagalume, ela se detém, canta e chama por sua Dama da Noite, a quem pede o agô para seguir caminhando sozinha - e nunca só - pelos becos e ruelas mais escuras da cidade. Em uma dança nebulosa em que desejo, devoção e afetação se comunicam e se confundem, as estórias 
e performances de filhos de santo e entidades parecem constituir um campo de forças compartilhado.

Chega segunda-feira e eu fico louca, quero rua, quero noite quero 'piroca'. Não sei o que faço, levanto, vou dar uma volta, ando pela noite sozinha, não consigo dormir. A rua é minha casa, aqui eu venho pra dormir e por causa da mamãe, claro, mas é na rua que eu me sinto bem. ${ }^{26}$

A Dama teria sido, segundo algumas versões, prostituta por opção, e conta-se que seu tempo em
Terra foi, como a maioria das biografias de pombagiras, marcado por episódios de violência de gênero - abusos, violência física, traições, escravização, feminicídio - a depender da estória. ${ }^{27}$ Do lado dos cavalos, o sofrimento dos corpos atravessa tudo em suas causas e suas curas, e diante dos imponderáveis da noite - sob o espectro onipresente da brutalidade cisheteropatriarcal de cada dia - a presença das Entidades parece muito mais concreta e acessível do que qualquer outra.

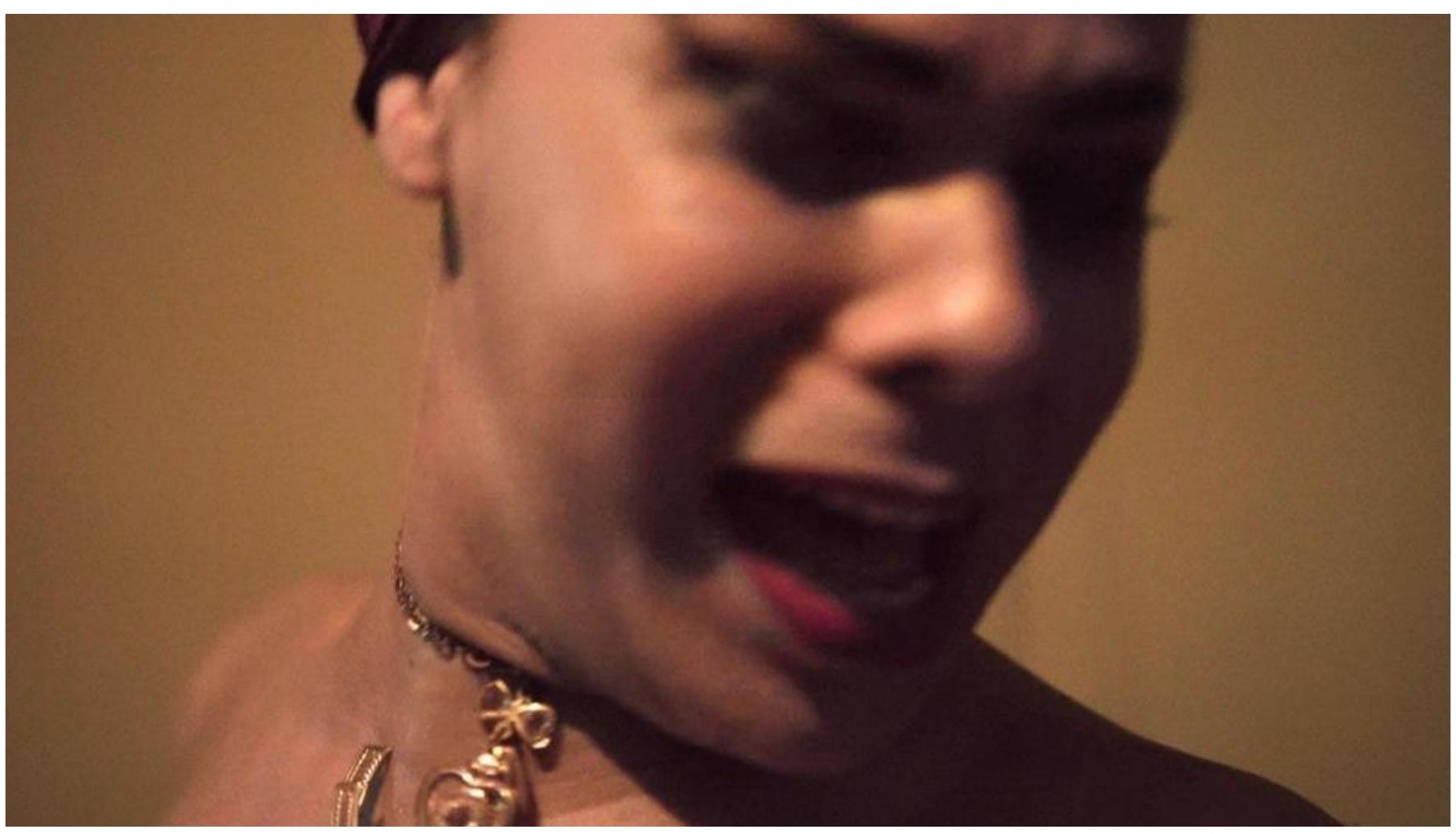

Fig. 7 - Camila Freitas e João Vieira Torres, BABADO, longa-metragem em desenvolvimento, 2022. 
"ACORDAR A BESTA-SOMBRA"28: ESCRITA E STORYTELLING

Em Falando em linguas: uma carta para as mulheres escritoras do terceiro mundo [ANZALDÚA, 2000 [1980]], Gloria Anzaldúa, escritora chicana, feminista, lésbica e ativista, conclama outras "mulheres de cor, companheiras no escrever" a exercitar a escrita como estratégia de sobrevivência e, ao mesmo tempo, a atravessaras próprias limitações para conseguir fazê-lo. "Esqueça o quarto só para si: escreva na cozinha, tranque-se no banheiro." ${ }^{29}$ Ao fazê-lo, forma-se uma rede, uma teia que fortalece e torna possível as suas práticas conectadas.

Em Manifesto Ciborgue [HARAWAY, 2019 [1991]], Donna Haraway recupera Anzaldúa e convida ativamente as mulheres a outra escrita: ser ciborgue no controle/apropriação do código, em uma lógica em que a fabulação, o pensamento especulativo e o storytelling se tornam instrumentos privilegiados para "fazer com", "pensar com" e "ficar com o problema" [HARAWAY, 2016]. Aprendemos com essas autoras que escrever [cartas, literatura, ciência ou código no circuito integrado] é ao mesmo tempo um ato literal e uma parcialidade de outras formas de respiração. Em seu processo de autoexperimentação e mutação, Paul Preciado retoma essas questões fundamentais para a produção de vidas e lutas desde os feminismos e nos permite entender a escrita e a palavra como hackeamento do gênero-e-sexualidade, da farmacopolítica, dos biocódigos [PRECIADO, 2018]; escrever é se encontrar, potencializar e compartilhar conhecimentos para atravessar a grande noite. ${ }^{30}$

Enquanto lugar conceitual desde onde se elaboram sobrevivências e se [re]criam, experimentam e produzem corpos e modos de habitar o mundo em indeterminação, nos perguntamos de que formas materiais e relacionais se pode habitar a fronteira - bem como o problema, a norma ou a violência - para além da ideia primordial de linha de cisão e de corte que acompanha essas noções. A ideia de sobrevivência, aqui, vem atravessada pela Fronteira, um território geográfico massivamente chamado assim, habitado, produzido e governado sob, apesar e através da premissa mito-conceitual desse nome, mas sobretudo pela noção de fronteira enquanto recurso conceitual apreendido especialmente do feminismo da terceira onda. ${ }^{31}$

Habitar a fronteira como arame farpado - "not comfortable but home" [ANZALDúA, 2012, p. 3] - é habitar um território de contradições e conflitos pleno de "ódio, raiva e exploração" e, ao mesmo tempo, inventar um modo de existir entre lugares de onde emerge uma nova consciência, uma que inclui o corpo - sua dimensão sobrenatural e profana -, e 
modos dissidentes de estar no mundo. A fronteira é um constante estado de transição. ${ }^{32}$

A escuridão, para Anzaldúa, é um elemento constitutivo dos corpos e psiques de um "povo que salta no escuro"33 e desafia a despossessão colonial. Enquanto alguns irão se conformar a tais valores, jogando "as partes inaceitáveis para as sombras", outros irão tomar outra direção e "tentar acordar a Besta-Sombra" dentro de si. Desde a margem, mas também atravessando para a outra margem dos combates identitários e políticos que marcam a experiência transfronteiriça, se ultrapassam as noções de luz e escuridão, bem e mal, e se inventam outras formas de caminhar pelo mundo, "[...]no ato de juntar e unir que não apenas produz uma criatura tanto da luz como da escuridão, mas também uma criatura que questiona as definições de luz e de escuro e thes dá novos significados." [ANZALDÚA, 2019 [1987]].

\section{MUTAÇÃO, EXPERIMENTAÇÃO E SOBREVIVÊNCIA: LAICON}

Laicon é um dos filhos de santo de Jairo que, como Quinho, vive em sua casa. Com Quinho também partilha o trabalho em um salão de beleza. O dono do salão, Angel, um homem gay de cerca de 40 anos, é conhecido por ter formado muitas meninas trans e meninos gays da cidade nos ofícios da beleza. Quan- do Laicon chegou, cerca de dez anos atrás, ele havia há pouco readotado seu nome de nascença, Erivelton. Angel, que também usa um codinome, Ihe disse que o seu nome de batismo era muito "pobre" para que fizesse uma carreira de sucesso como cabeleireiro, e o rebatizou Laicon.

Antes disso, por volta de 2007, Laicon/Erivelton se chamava Jamile, e era uma jovem travesti. Após a primeira parada LGBT de Tabatinga, ele conta que todas as gays estavam bebendo e dançando no Lua Nova. A certa altura, Jamile endoidou e quis ir embora sozinha, apesar do acordo tácito entre elas de sempre voltar para casa com companhia. No caminho, foi surpreendida por um dilúvio amazônico, desses que começam repentinamente e dão a impressão de que o mundo vai acabar. Abrigada sob uma marquise do comércio fechado às três da manhã, viu uma camionete parar, e um homem que ela reconheceu como policial civil da cidade [à paisana] Ihe oferecer carona. Ela aceitou, mas ao entrar no carro percebeu que não havia apenas um, mas três policiais. Dentro do veículo, eles começaram a Ihe dizer insultos e provocações. Suas rezas não a impediram de ser arrastada para o interior de uma famosa ruína no centro de Tabatinga, em frente a um terreno baldio, onde os três policiais a espancaram e torturaram. Laicon, então Jamile, conta que os policiais colocaram uma arma em sua 
boca e, aos gritos, diziam que ela tinha HIV e que eles iriam "apagar uma aberração" de que o mundo não sentiria falta. Ele conta que foi salvo, em uma cena épica, por Nena Machuda, uma amiga travesti, que viu a cena de longe e gritou.
Laicon deixou de ser travesti "porque queria viver". E nesse novo jeito de encarar o "viver", foi transitando um outro caminho de corpo, de trabalho, de religião, de gênero-e-sexualidade. Durante muito tempo, ao voltar a ser um homem cis, só tinha encon-

tros com parceiros heterossexuais ${ }^{35}$ que, para ele, tinham uma relação objetificante e egoísta com o seu corpo: "Eles me comiam, gozavam e Laicon ficou em choque, marcado pelo trauma por muito tempo. Ao chegar em casa, o tio, uma figura conhecida na cidade, o puniu com uma surra e, no dia seguinte, levou-o à Polícia Civil para fazer um boletim de ocorrência. Com a mediação dele e de um escrivão importante para o mundo gay de Tabatinga, Laicon pôde ter uma sessão de reconhecimento dos suspeitos do crime. Durante o processo, o escrivão aconselhou que ele aceitasse a indenização que permitiria arquivar o processo. "Era aceitar ou morrer, pois se não aceitasse os policiais podiam fazer alguma coisa". Os agentes foram afastados para outro município, mas não foram presos. Como efeito traumático da forte violência, Laicon associou a própria sobrevivência a uma mudança de rumos radical: parou de sair à noite por bastante tempo e, em seguida, deixou de se travestir, voltando a ser Erivelton. tchau. Só vim a ter prazer quando passei a sair com homens gays e entendi como duas pessoas podem ter prazer juntas".

\section{IMAGEM TRANS: SOBREVIVÊNCIAS EREVERSIBILIDADES}

Contrariando os polos opostos de apocalipse e redenção da tradição judaico-cristã ocidental, as sobrevivências se distanciam do horizonte da salvação - que "nos promete a grande e longínqua luz [luce]" [DIDI-HUBERMAN, 2011, p. 85] - e se afirmam nas potencialidades menores - "pequenas luzes"36 que se apreendem, sobretudo, desde a escuridão. De maneira análoga, a imagem, em vez de manifestação de visibilidades onipresentes e programáticas, se constitui através da falha, nas frestas e fissuras do tempo que permitem a sua aparição e desaparição, na intermitência de vagalume para reaparecer 


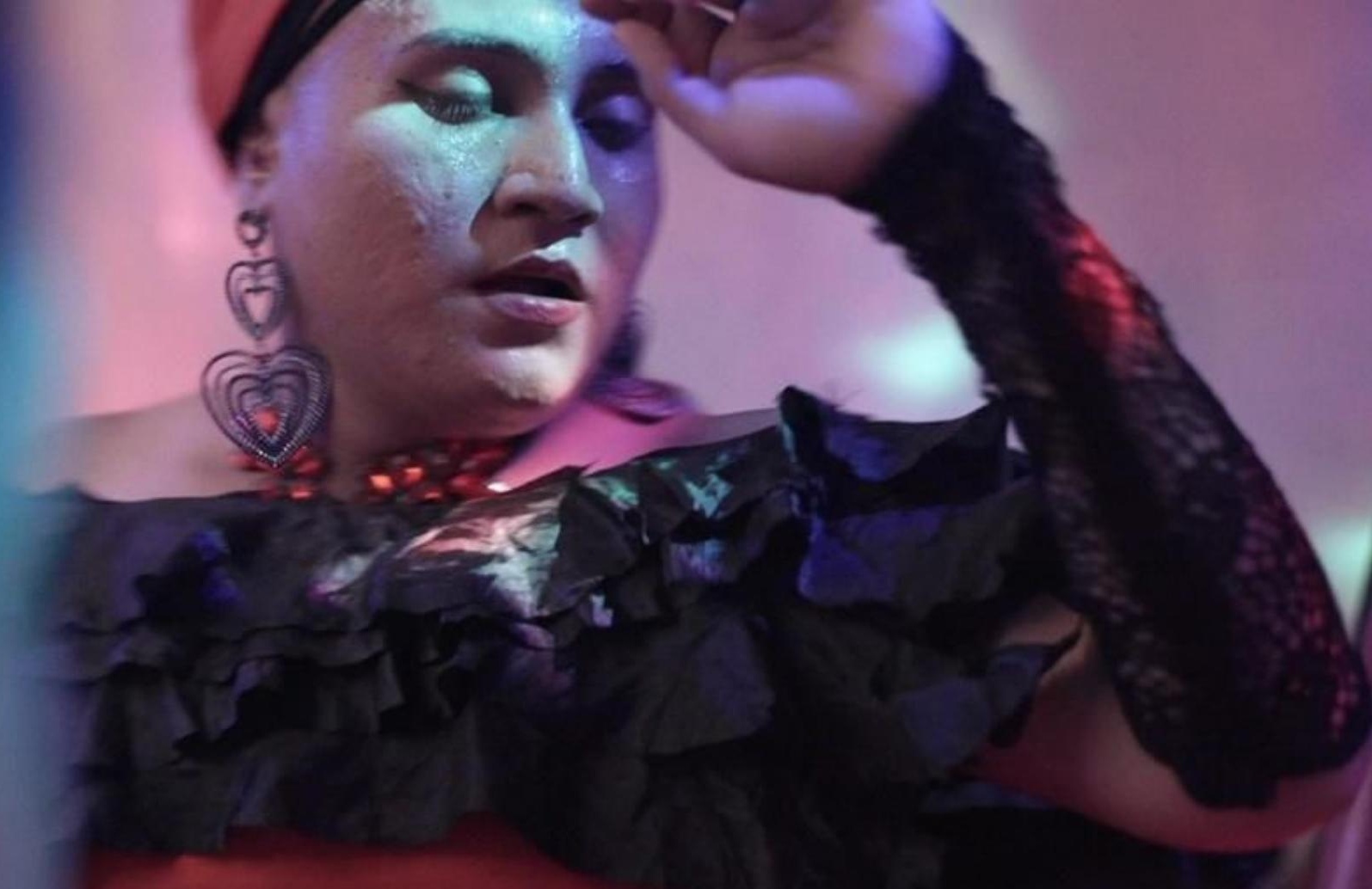

Fig. 8 - Camila Freitas e João Vieira Torres, BABADO, longa-metragem em desenvolvimento, 2022.

e sobreviver. ${ }^{37}$ A imagem se torna perceptível no espaço "das aberturas, dos possíveis, dos lampejos, dos apesar de tudo", onde os gestos menores dos contrapoderes reinventam as formas do possível e criam "zonas ou redes de sobrevivências no lugar mesmo onde se declaram sua extraterritorialidade, sua marginalização, sua resistência, sua vocação para a revolta." [DIDI-HUBERMAN, 2011, p. 42]
A imagem que emerge dessa escuridão constitutiva habita um território de fronteira ou, para Marie-José Mondzain, uma zona - um no man's land ou terreno baldio, lugar fora de toda topologia - que designa uma "forma de habitar o mundo para um sujeito nômade, clandestino, ilocalizável e cuja identidade fugidia escapa a qualquer controle, a qualquer determinação de residência e de identidade." ${ }^{38} \mathrm{O}$ Revista Poiésis, Niterói, v. 23, n. 39, p. 18-54, jan./jun. 2022. [DOl: https://doi.org/10.22409/poiesis.v23i39.52941] 


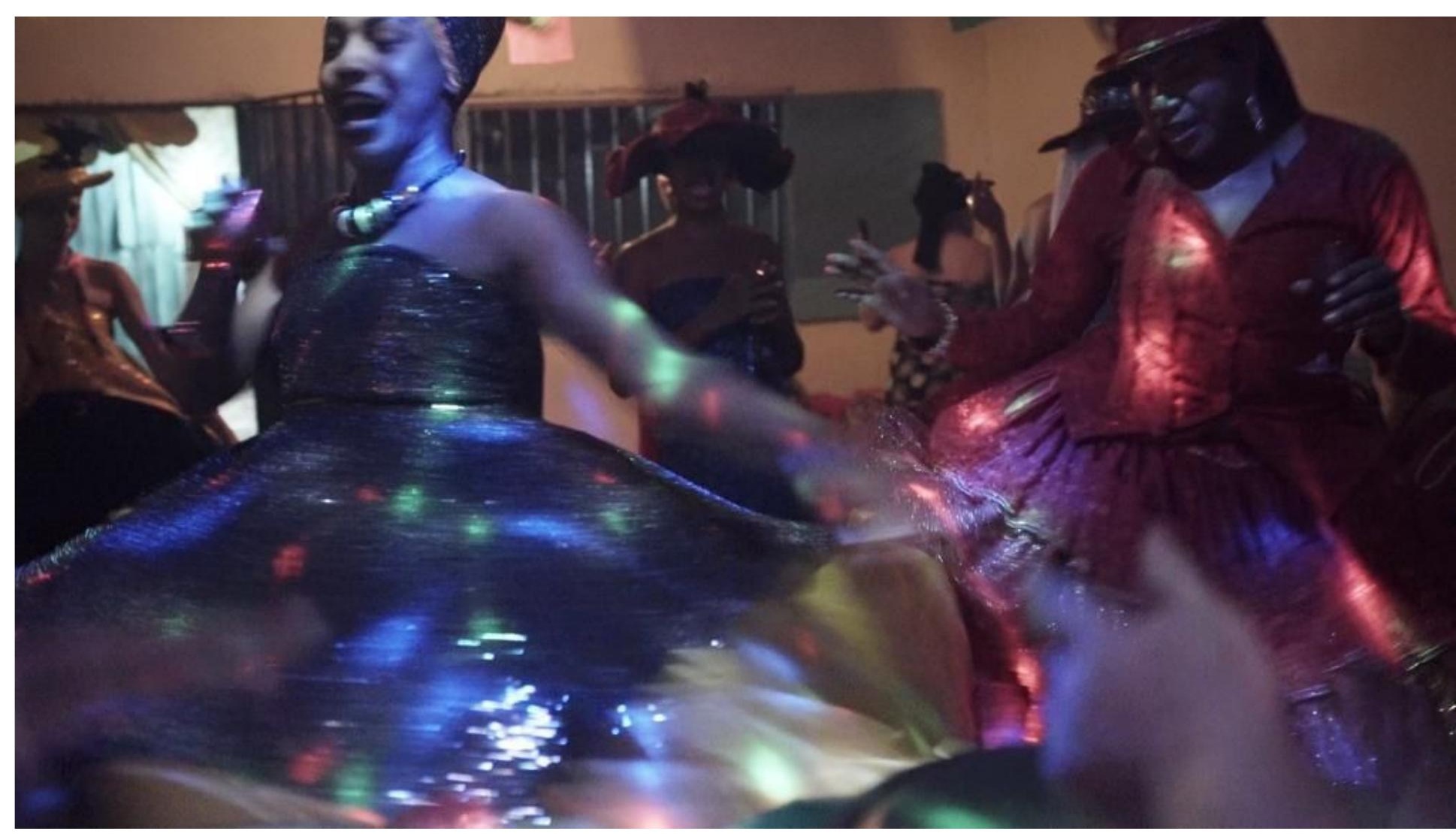

Fig. 9 - Camila Freitas e João Vieira Torres, BABADO, longa-metragem em desenvolvimento, 2022.

sujeito da zona, tal qual a própria imagem, habita o coração do visível e dos dispositivos sociopolíticos de poder, ao mesmo tempo em que borra os seus contornos. [MONDZAIN, 2012, p. 84-85] As operações imagéticas portam em si a energia de indeterminação que nos permite agir apesar e através das epistemologias racionalistas do ocidente que delimitam o visivel e as formas de ver, habilitando-
- nos a ver no escuro e a mergulhar nas sombras que conferem à imagem seu aspecto furtivo, indecifrável, indecidível - que estão, para a autora, no cerne de nossa liberdade de ver.

Em vez de [apenas] representação, energia: "As operações imagéticas são gestos energéticos que podem se apropriar de todos os materiais e signos. Pintar, cantar, filmar, dançar..." [MONDZAIN, 2012, 
p. 95] - ao que podemos aqui acrescentar fabular, transitar, incorporar, se montar, inventar, brincar, gozar, dar close, curtir -, são gestos que ativam no real a energia revolucionária das imagens. [MONDZAIN, 2012, p. 100] Contaminar o cotidiano das forças contra-hegemônicas é, seguindo as pistas da autora, criar um lugar de acolhida ao outro, uma zona que nos permite operar pela força das energias ficcionais e trazer para o horizonte dos possíveis a subversão de todas as hierarquias violentas, a descolonização do pensamento, a feminização do poder, e a redescoberta do transe. [MONDZAIN, 2012, p. 95] Apostamos, junto com ela, na potência da imagem, da poesia e de outras linguagens artísticas rumo a um devir zoneiro que ultrapassa as fronteiras do impossivel para criar e transformar o mundo. Como dizia Audre Lorde, "a poesia faz alguma coisa acontecer" [LORDE, 2020, p. 106].

\section{RETOMANDO A NOSSA EPÍGRAFE:}

\author{
Les opérations imageantes connaissent toutes les \\ permutations, renversements, réversibilités qu'il s'agisse \\ du sexe, du genre, de la place sociale, du partage des \\ pouvoirs et des forces. Les images sont trans-genre, queer \\ parfois, transgénériques toujours [MONDZAIN, 2012, p. \\ 102, grifo da autora].
}

O território entre lugares que se cria entre macumbeiros e espíritos, em que a lógica e um certo ethos do ritual e do transe transbordam para além de seu próprio espaço-tempo, pode ser pensado como uma zona de reversibilidade. Nela, indefinição e ambivalência são condições de possibilidade da coabitação transgenérica e transontológica que se realiza por meio da produção de imagens num sentido amplo - entre performatividades, narrativização, sonho, transe, sexualidades e religião. Em uma superposição nebulosa de dimensões espirituais, materiais, afetivas, estéticas e políticas, as margens dessa coabitação não constituem, porém, uma linha estanque de separação entre mundos que pode ser simplesmente "atravessada"; pensando com Vincent Capranzano, imaginamos que a fronteira, aqui, atua como uma chave produtora de uma "mudança de registro ontológico" que postula "um além que é, por sua natureza íntima, inacessível de fato e de representação", a partir de onde os horizontes se alargam e se descolam da "insistente realidade do aqui e agora" para acessar o espaço do imaginário [CRAPANZANO, 2005, p. 367].

Este, enquanto espaço do sonho, da fantasia e do transe, mas também como terreno de ficcionalidades ancoradas no real - fabulações - é preenchido por uma matéria narrativa ilocalizável - "atópica, 
louca, extravagante e hipertópica”, em que o irrepresentável opera através de "sobreimpressões" e "invaginações" narrativas [double bind/ band/ blind] [DERRIDA, 2003, p. 149]. Derrida nos fala da "voz narrativa" que, segundo Maurice Blachot, está "tanto dentro quanto fora e não pode se encarnar"; "lugar sem lugar" que nos convoca à fantasia espectral, fantasmática, e à suspensão do tempo no espaço intersticial entre vida e morte, tempo próprio da sobrevivência [DERRIDA, 2003, p. 149].
A fronteira aqui, acreditamos, se manifesta em um espaço de permeabilidade narrativa entre mundos, atravessado pelo invisível, e pode ser pensada como um espaço-tempo de sobrevivência - survivance et revenance ${ }^{39}$ - na medida em que vida e morte estão implicadas em um arrêt, uma suspensão que dá lugar a um presente "pleno de agoras", e rompe com o tempo histórico linear, progressivo e teleológico dos vencedores da vez [FACINA; SILVA, LOPES; 2019, p. 19]. Do lado dos

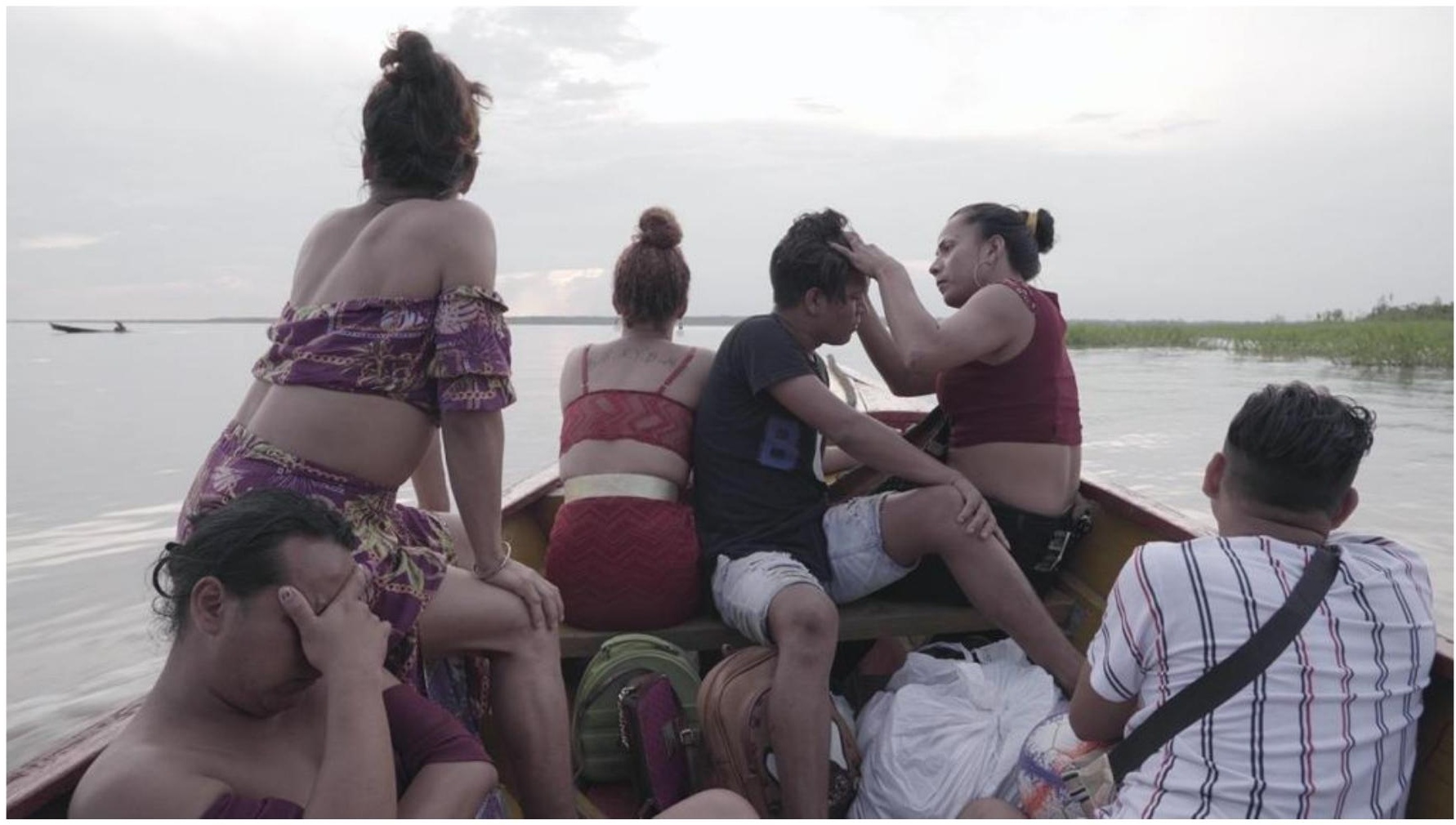

Fig. 10 - Camila Freitas e João Vieira Torres, BABADO, longa-metragem em desenvolvimento, 2022.

FREITAS, Camila; OLIVAR, José Miguel. imagem trans: transe, fabulação e sobre vivências na fronteira. 
contrapoderes, avistamos um emaranhado interseccional em que pessoas LGBTQ+, mulheres e praticantes de religiões de matrizes africanas são agências sobrescritas pelas vozes insurgentes do povo da rua, que retornam do reino da morte para suspender o tempo e gozar da vida em sua máxima potência - bebendo, dançando, girando, dançando, cantando e contando.

\section{CINE-ETNO-TRANSE: FABULAÇÕES NA ENCRUZILHADA}

À imagem da ambivalência e da indecidibilidade características de Exu ${ }^{40}$, a encruzilhada, lugar privilegiado de atuação do orixá, é, tal qual a fronteira, um espaço de hibridizações através das quais se subvertem fronteiras de subalternização. Na concepção filosófica nagô/iorubá e na cosmovisão banto, trata-se do "lugar sagrado de intermediações entre sistemas e instâncias de conhecimentos diversos", constituindo, na esfera do rito e da performance, um "lugar radial de centramento e descentramento" onde se travam confrontos, desvios, confluências e divergências de saberes diversos e sentidos plurais [MARTINS, 2003, p. 70].

Na encruzilhada de saberes, modos de existência, encontros e choques cosmológicos em que buscamos fazer sentidos e fabricar mundos junto com elas, nós-cineastas, nós-etnógrafos e nós-personagens nos disponibilizamos a um estado de transição constante, a tornar-nos outros juntos. Em uma busca por atingir "não um cinema da verdade, mas a verdade do cinema"4.1 , é necessário filmar a própria fronteira entre o real e o ficcional, onde reside o que Deleuze chamou de função de fabulação, não para apreender "a identidade de uma personagem, real ou fictícia", mas "o devir da personagem real quando ela própria se põe a 'ficcionar', quando entra 'em flagrante delito de criar lendas', e assim contribui para a invenção de seu povo." [DELEUZE, 2005, p. 183]. O cineasta, a seu tempo, torna-se outro na medida em que vira médium, mediador, quando toma "personagens reais como intercessores, e substitui suas ficções pelas próprias fabulações deles [...]" [DELEUZE, 2005, p. 185].

As múltiplas dimensões das imagens com as quais lidamos neste trabalho - imagens que emanam das estórias das Entidades e as habitam, imagens enquanto performances de um imaginário cosmopolítico, imagens que encarnam/iconizam o substrato imaterial do transe e da fé, imagens de imagens produzidas por nós - delineiam um objeto de pesquisa de difícil apreensão, em constante construção e sem perspectiva de assentamento completo, que se constitui em meio a uma série de processos cognitivos, perceptivos, sensoriais, espirituais e artísticos em curso. 
Segundo uma certa perspectiva da etnografia performativa ${ }^{42}$, o objeto enquanto "ação performativa" leva em conta os seus deslocamentos e processos na própria constituição e transmissão do mesmo. Enquanto "ato performativo de reapropriação ou de reescrita", o processo etnográfico não mais se contenta em construir uma análise para "decifrar as significações culturais do objeto" [MARGEL, 2017, p. 159]; este, por sua vez, passa a ser entendido como "um observatório, etnográfico ou artístico" e se constitui na hipótese de que a "observação do objeto restitui alguma coisa ao objeto, um saber, uma história, uma guerra, uma destruição, que vale como sobrevida para o objeto." [MARGEL, 2017, p. 161].

A diferentes alturas do processo, uma série de perguntas nos interpelam: de que formas se pode filmar o ritual e o transe, respeitando o "sítio de indeterminação invisível" [MONDZAIN, 2012, p. 90] da zona? De que formas é possível criar imagens sem fechar sentidos ou determinar causalidades, agindo na fronteira das ficções, da voz e da palavra performativas [PRECIADO, 2019, p. 96]? Se certas práticas e ritos desempenham funções no seio de uma determinada comunidade dentre as quais podemos ler mecanismos de sobrevivência, tecnologias de cura ou redução de danos -, em que medida pode fazer sentido criar e lançar imagens - reflexos ou duplos - das mesmas para fora dela? É possível criar visibilidades integrando a escuridão constitutiva que as resguarda da luz encegueirante do pensamento unívoco?

Tais questionamentos e buscas não se exaurem e não poderiam, no escopo deste experimento em processo, levar a respostas definitivas. No entanto, em campo, tentamos formulá-las de diferentes maneiras. Uma delas foi por meio do diálogo com filhos de santo e Entidades sobre o processo de filmá-las, dentro e fora dos rituais do terreiro. Ao final da primeira gira a que comparecemos juntos e com a câmera, em um ritual para "caboclo", Dona Herondina ${ }^{43}$, na cabeça do pai Jairo, nos convidou a nos apresentar. José Miguel foi o primeiro a ir à frente do congá para explicar que, dessa vez, vinha acompanhado para tentar fazer um filme com os filhos e filhas, as Entidades e o terreiro. Em seguida, Camila e João se apresentaram, agradecendo a acolhida do pai de santo e reverenciando as entidades, e pedindo ao conjunto de médiuns e às entidades o agô para estarmos ali - filmando - no meio da gira. Ao final da apresentação, Dona Herondina falou de José Miguel às entidades presentes como um velho amigo que já anda por ali há muitos anos, definindo-o, debochada, como pesquisador de "tudo o que não presta": "ele pesquisa os adés, que na língua são as 'florzinha', os 'viados'... pesquisa travesti, pesquisa prostituta, pesquisa macumba, o caralho a quatro!". E perguntou: "Cê não tem não alguma coisa pra mostrar aí pro povo da macumba?". 

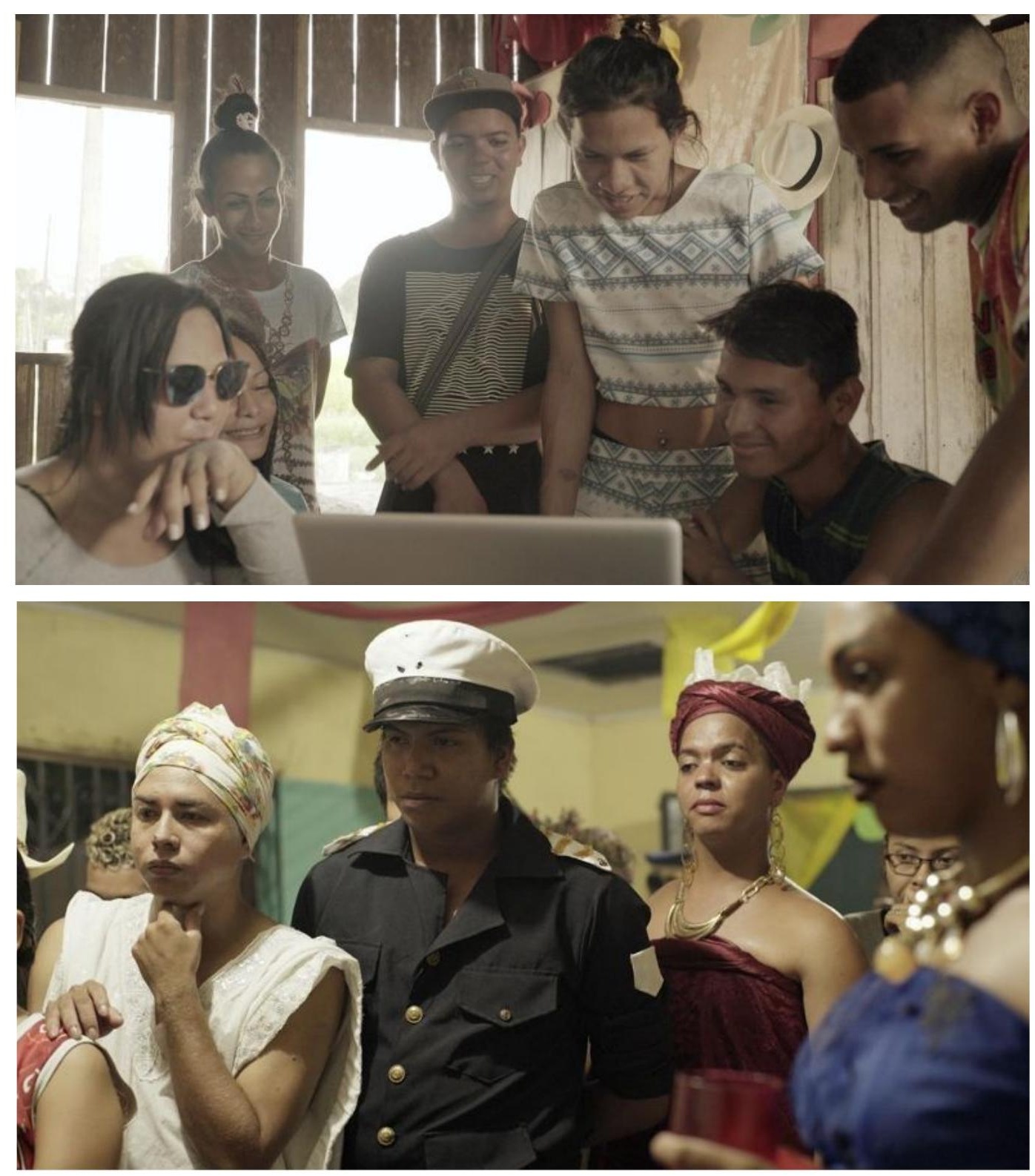

Fig. 11 - Camila Freitas e João Vieira Torres, BABADO, longa-metragem em desenvolvimento, 2022.

Fig. 12 - Camila Freitas e João Vieira Torres, BABADO, longa-metragem em desenvolvimento, 2022. 
Os espíritos pediram para ver. Assim, com o computador apoiado em um tambor, mostramos um trecho de 3' que havíamos editado a partir das imagens feitas por José Miguel nos anos anteriores. Os cerca de vinte presentes - entre Entidades, seus cavalose assistência - assistiram com entusiasmo, reconhecendo uns e outros entre zoação, gargalhadas e reflexões políticas sobre o estatuto dessa macumba feita por "florzinhas" e sua inserção na sociedade cristã-patriarcal. Dona Herondina concluiu que esses trabalhos poderiam ser úteis para "mostrar pro povo lá fora o que é a macumba", em vista de tantos preconceitos enfrentados pelos filhos e filhas de santo.

Dentro e fora das impossíveis margens rituais e de virtualidade/atualização, o objeto desta pesquisa emerge e se constitui, tal qual os sujeitos, através da criação desse espaço narrativo e performativo que se partilha entre nós e elas. Assim, nossa presença não repousa sobre uma observação neutra, produzindo efeitos sobre nossos corpos e subjetividades, mas também sobre os corpos e performances oferecidas à câmera, sobre o ritual e as entidades. Hóspedes intrusos dessa coabitação, vamos buscando encontrar os nossos papéis dentro de um jogo de implicações mútuas, construído e negociado em diferentes e insondáveis instâncias materiais e espirituais, de forma a integrar a performance ritual no momento em que a filmamos, editamos e projetamos.
Em um célebre ensaio sobre o que ele mesmo chamou de cine-transe[ROUCH, 2003 [1973], p. 87-126.], Jean Rouch reflete acerca dos estados de possessão e transe, pensando o lugar do cineasta-etnógrafo em meio aos rituais em que esses acontecem. Segundo ele, na cosmovisão dos Songhay-Zarma, da região do Níger, o mundo e tudo o que ele contém é duplicado em um universo paralelo povoado de duplos ou bias. O duplo - bia -, conceito nebuloso que designa "ao mesmo tempo ‘sombra' [literalmente significa escuro], 'reflexo' [em um espelho ou poça d'agua], e 'alma' [princípio espiritual de todos os seres animados]" [ROUCH, 2003 [1973], p. 89], acompanha o corpo do indivíduo todo o tempo de sua vida, deixando-o definitivamente no momento de sua morte para seguir seu curso na eternidade, ou apenas temporariamente durante as crises de possessão. ○ "dançarino" para os Songhay - que nós conhecemos por cavalo ou médium - é quem, sob o ritmo dos tambores sagrados, será "montado" pela entidade enquanto o seu duplo permanece protegido até que o transe cesse e ele possa retomar o seu lugar junto ao corpo da pessoa. O mundo dos biasé, segundo Rouch, "a casa permanente do imaginário [sonhos, reveries, reflexos]", e o transe uma das conexões possíveis entre os dois mundos, que se interlaçam de tal maneira que se torna quase impossível para pessoas exteriores distinguirem o "real" do "imaginário". ${ }^{44}$ 


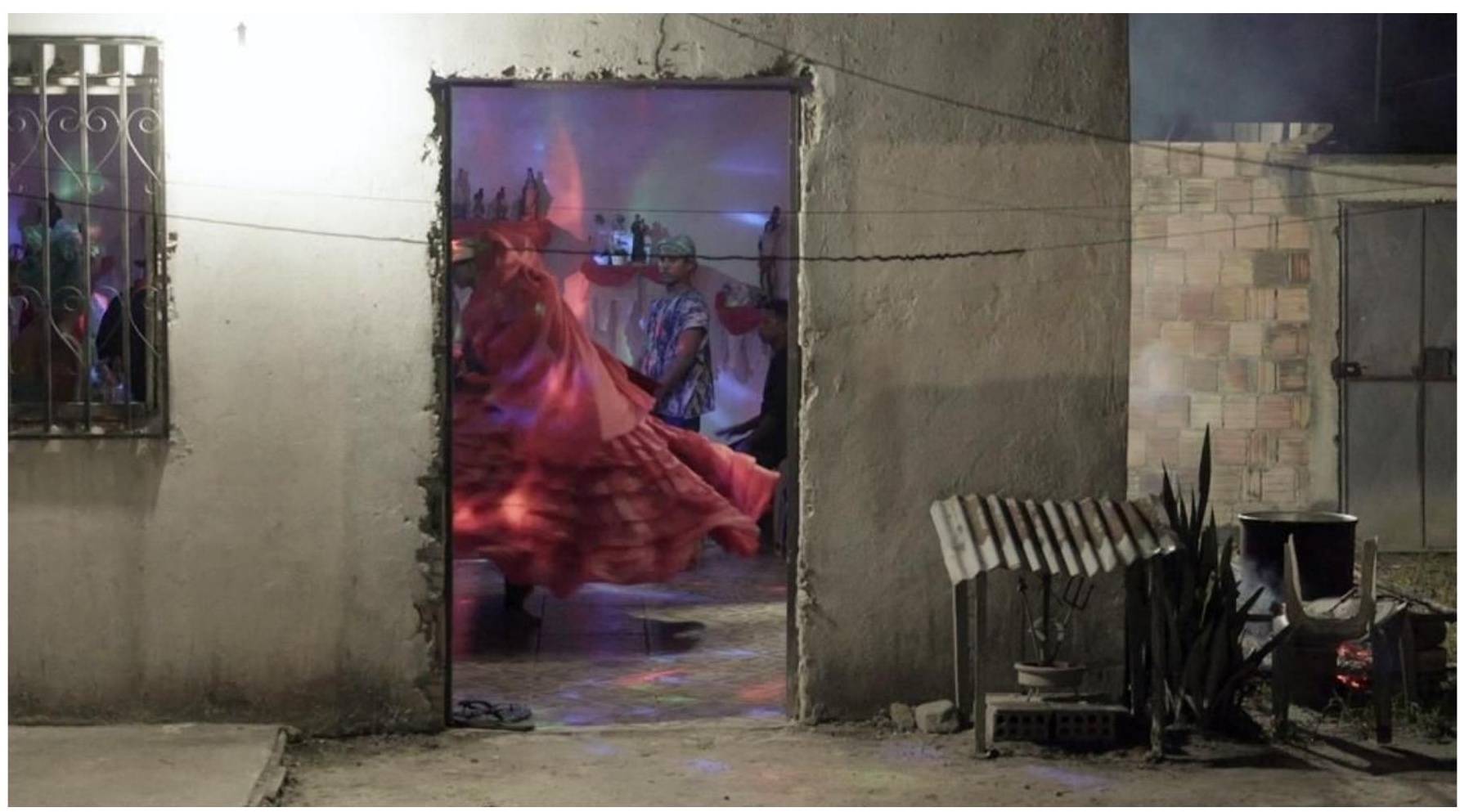

Fig. 14 - Camila Freitas e João Vieira Torres, BABADO, longa-metragem em desenvolvimento, 2022.

espectral, fabulada e imaginada sob fusionantes matizes de cor, luz e sombra que a inscrevem no espectro visível, é também matéria-prima de um certo ciné-transe que invocamos para dançar junto aos corpos dos médiuns e adentrar, cada um/a à sua maneira, a encruzilhada de reflexos e duplos antropofágicos onde emerge o invisível. Ao disponibilizar os nossos corpos a esse estado alterado de [cine] visão e [cine] escuta, podemos tentar, tal como Rouch preconizava, nos libertar do "peso das teorias cinematográficas e etnográficas" e "redescobrir a barbárie da invenção". ${ }^{46}$

CONSIDERAÇÕES FINAIS: FORMAS DE PRODUZIR E ATRAVESSAR O MUNDO NA FRONTEIRA

Como experiências de contato direto e cotidiano com múltiplas violências informam a ontologia e as condições de persistência de um corpo, de uma rede inteira e de um mundo que se produz contra-hege- 
mônico? Ainda que fora de contextos de guerra franca ou institucionalizada, a ação insidiosa, velada e permanente de estruturas de poder normativo contra corpos/existências tais como os de Quinho/Tilinha/ Tatá Molambo, Jamile/Erivelton/Laicon e Cris, mobilizam um estado permanente de risco e precarização intensificada.47 Da mesma forma, a resistência e a persistência dos mesmos estão intimamente relacionadas ao conjunto de relações que cada corpo encontrará com a norma que o circunda, bem como as formas de hackeamento da mesma. ${ }^{48}$

Se esquivar da violência é tarefa cotidiana, a produção de novas fronteiras e novas alianças é vital para garantir a persistência - não apenas física, mas também a beleza, o prazer e a "curtição", aspectos centrais e constitutivos para essa rede. No fluxo narrativo e fabulativo de Laicon, é através do reenquadramento do prazer sexual e da afetividade homossexual que vai se construindo a evasão da experiência traumática, ou a capacidade de ler e escrever em novas chaves a história vivida. Já para Cris e Quinho, a sobrevivência está assegurada na medida em que elas consideram ultrapassada a opressão com base na abjeção [BUTLER, 2019 [1996]] que perpassa suas experiências de gênero-e-sexualidade. Enquanto Laicon costura sua identidade de gênero entre lugares como forma de habitar sua sexualidade plenamente, Cris, por sua vez, evoca em suas falas o sonho de ser "100\% mulher". Entendemos que essa meta diz respeito, para além de um ideal de cisgeneridade, à aquisição de uma série de direitos - como ir ao banheiro no bar sem ser agredida pelos homens ou rejeitada pelas mulheres e ter a seu lado um parceiro que a assuma "em plena luz do dia", sem abrir mão do trânsito entre a beleza feminina que brilha na noite e se esgueira através dos intervalos escuros, aonde ela encontra a própria força.

Já a "libertação" à qual Quinho se refere, no momento em que ela se descobre travesti e encontra aceitação de suas pares, após romper com as instituições que a oprimiram e silenciaram por anos - a família e a igreja -, coincide com a sua conexão à umbanda, outro evento que, em sua vida, aparece como libertador. Ainda que, ao entrar na religião, ela passe a compreender o seu lugar no mundo a partir de uma série de novos preceitos, regras e hierarquias, o seu lugar de sujeito das margens passará a coincidir com aquele de boa parte dos membros de sua família escolhida, sendo eles encarnados ou entidades.

O terreiro, um "simples montículo de terra", na Terra, nessa terra fronteiriça, é produzido por e produz todo um sistema tecnológico de crescimento, de relação e de atravessamento do Mundo, ou das "fronteiras sociais", como sugere Vânia Zikán Cardoso. Um dispositivo material e coletivizante de indeterminação e sobrevivência que favorece en- 


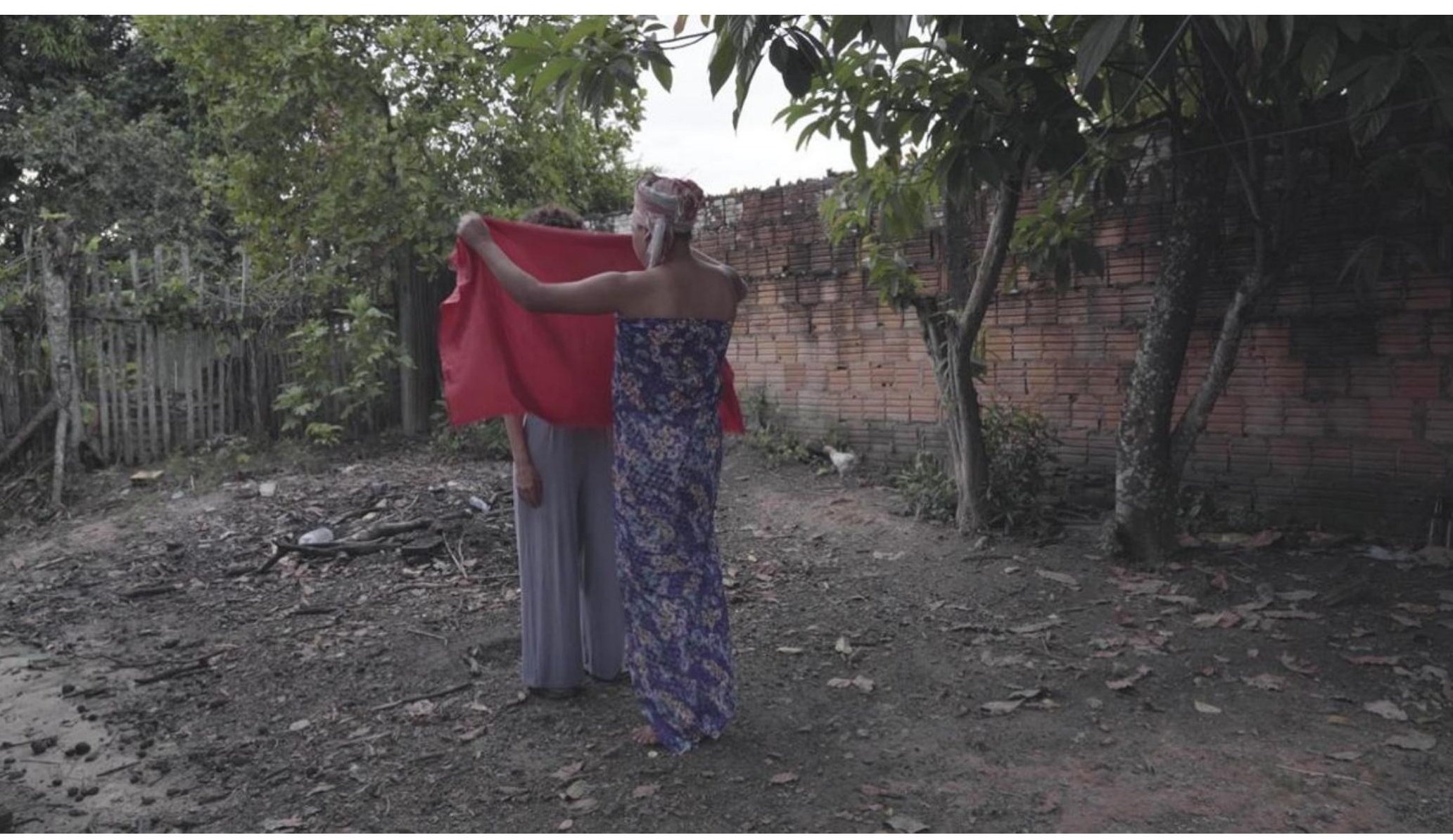

Fig. 16 - Camila Freitas e João Vieira Torres, BABADO,longa-metragem em desenvolvimento, 2022.

Revista Poiésis, Niterói, v. 23, n. 39, p. 18-54, jan./jun. 2022. [DOl: https://doi.org/10.22409/poiesis.v23i39.52941] 
8 Durante dez anos, a partir de 2010, José Miguel Olivar desenvolveu esses e outros temas a partir do terreiro de pai Jairo,

1 Vânia Zikán Cardoso explica como, apesar dos usos pejorativos e acusatórios que levaram a um certo descrédito político-acadêmico da palavra macumba, ela mantém sua vitalidade polissêmica e vigência positiva em diversos âmbitos das religiões afro-brasileiras. O termo emerge como conceito ressignificado e reterritorializado em função de práticas racializadas e de resistência, associadas a uma cosmovisão marcada pela presença dos espíritos. [CARDOSO, 2007a, p. 340].

2 Neste trabalho, dedicamos especial atenção à porção da prática umbandista denominada "de esquerda", isto é, ligada aos fundamentos de Exu, orixá que rege o povo da rua - pombagiras e exus. Segundo Vânia Zikán Cardoso, trata-se de uma falange de "espíritos de malandros e de prostitutas, personagens que em vida teriam ocupado espaços socialmente marginalizados". [CARDOSO, 2007a, p. 1].

3 No uso corrente da Umbanda, o termo de origem banto calunga [pequeno] significa cemitério, enquanto Calunga [grande] é o mar.

\section{Como recurso linguístico distintivo, nos referimos ao orixá} Exu e às entidades nomeadas exus com uso de maiúsculas e minúsculas.

5 Ponto de exu.

6 Formada pelas cidades de Tabatinga/Brasil, Santa Rosa/ Peru e Letícia/Colômbia, essa tríplice fronteira localiza-se na região do Alto Solimões, extremo oeste do Amazonas.

7 "As gays" é como os meninos e meninas LGBTQ+ da rede em questão se referem a si próprias, no coletivo e no feminino, ainda que seu fluxo inclua tanto mulheres transgênero quanto meninos [e mais raramente meninas] gays cisgênero. seus filhos e filhas de santo, em Tabatinga, no Amazonas. Pesquisas realizadas principalmente com financiamento da Fundação de Amparo à Pesquisa do Estado de São Paulo [FAPESP], através de três apoios sucessivos: processos 2010/50077-10, 2013/26826-2, e 2019/01714-3, sendo este último sediado na Faculdade de Saúde Pública da USP. Por sua vez, a pesquisa teórico-prática de mestrado de Camila Freitas, na linha de linguagens visuais da EBA/UFRJ e com orientação de Tadeu Capistrano e coorientação de José Miguel Olivar, articula-se à realização do filme Babado e à escritura deste texto.

9 Babado é um projeto de longa-metragem entre o documentário criativo, a ficção e o filme-ensaio, codirigido por Camila Freitas e João Torres, e com colaboração integral de José Miguel Olivar. Em 2018 e 2020, a equipe visitou a Fronteira no quadro da realização do filme. O projeto de filme obteve o apoio do Institut Français em 2020 e, em 2021, o apoio do Fundo de Gotemburgo [Development Supporf]. Para um primeiro teaser https://vimeo.com/448164053. Acesso em 5/12/2021.

10 Compreendemos "a noção cosmopolíitica como uma intervenção disruptiva e conectiva de habilitação do múltiplo para atravessar e compor o mundo comum". [OLIVAR, 2019].

11 Nas palavras de um conhecido pai-de-santo de Manaus e mentor de Jairo [OLIVAR, 2019].

12 Durante alguns dias em 2020, realizamos oficinas de contação de estórias junto à rede. Nesses encontros, propusemos jogos e interações a partir de temas pré-determinados que lançávamos ou que surgiam das conversas delas. Os dispositivos eram livremente inspirados do jogo de cadavre exquis: um deles convidava todas as presentes a contarem uma experiência pessoal como, por exemplo, a do primeiro amor, em que a "pessoa 
amada" era chamada por um só nome por todas as narradoras, formando uma grande estória de amor desigual e sem fim; em outro, duas pessoas trocavam estórias em torno de seus nomes e nascimentos e, numa etapa seguinte, cada uma ia à frente para narrar a estória da outra em primeira pessoa, se apropriando e fabulando sobre a mesma [e assim criando uma estória estrangeira às duas primeiras].

13 Seguimos Vânia Zikán Cardoso [2007a] em sua opção pelo vocábulo "estória", pelo fato deste se relacionar às ideias de fabulação, narrativa, ficção. Tal como a autora explica, essa escolha não nega o caráter documental ou "real" dessas narrativas, mas explicita o caráter de invenção e criação implicado em todo ato narrativo, e o terreno de ambiguidade e tensão entre "real" e "imaginário".

14 Relatedness, nos termos de Carsten [2000].

15 Ponto de pombagira, cantado por Dona Tata Molambo no terreiro de pai Jairo, fevereiro/2020.

16 Ponto de pombagira, cantado por Dona Tata Molambo na ocasião de sua conversa conosco, setembro/2018.

17 Na gíria das gays: "balada", curtição, saídas noturnas envolvendo glamour e "montação".

18 cf. SZTUTMAN, 2018.

19 As discussões de Judith Butler acerca da performatividade - para pensar a relação entre gênero e sexo -, em que a autora argumenta, segundo Vânia Zikán Cardoso, que "o performativo não é meramente um ato utilizado ou realizado por um sujeito dado a priori, mas uma parte crucial tanto da formação do sujeito quanto da contínua contestação política e reformulação do sujeito", são retomadas por esta última para pensar sobre o papel das estórias e performances narrativas na constituição do sujeito narrador na macumba. [CARDOSO, 2007b, p. 209].

20 Tradução Nossa.
21 A noção de narrativização vem inspirada pela abundante obra de Vânia Zikán Cardoso sobre a produção narrativa e performativa no contexto das macumbas cariocas, em "um espaço em que vidas são narradas e estórias são vividas [...] Aqui, a narrativização não se refere a um mundo a ser revelado pela interpretação do que é contado, não expressa apenas uma prática, mas constitui a própria prática por ela significada. Esta prática narrativa, na qual estórias são contadas de maneira dispersa e fragmentada, abre um espaço interpretativo no qual os sujeitos da experiência - tanto "espírito" quanto "macumbeiro" - são engendrados através do próprio ato narrativo." [CARDOSO, 2007a, p. 318].

22 Em outro lugar, Olivar desenvolve uma descrição detalhada do terreiro desde as suas materialidades e suas relações. Argumenta-se que o terreiro do pai Jairo funciona como um dispositivo central para uma tecnologia de fabricação de um mf\# [mundo-pra-nós], apesar e através do Mundo-como-Ameaça [MfA], fazendo então emergir uma relação maior com o Mundo-como-embate [M/e] [OLIVAR, 2019].

23 Em 2011, na ocasião de uma oficina sobre gênero-e-sexualidade ministrada por José Miguel Olivar em Tabatinga, quando ele conheceu e se aproximou da rede, Cris se definia como "menina", distinguindo-se da nominação exógena "travesti" ou "transgênero". Em muitas conversas entre 2018 e 2020, ela relacionou uma suposta "incompletude" da sua condição de mulher à impossibilidade de gerar e parir. Segundo ela, se pudesse, teria muitos filhos. Por outro lado, chama por esse nome os seus quatro sobrinhos, filhos de Eliane.

24 "Puta", na gíria local.

25 Fala de Cris em setembro/2018, gravada em um bar, durante a pesquisa para o filme Babado.

26 Fala de Cris em setembro/2018, gravada em sua casa, durante a pesquisa para o filme Babado. 
"Tanto estórias como espíritos deslocam-se entre enquadres, presentificando assim a própria passagem entre o 'ritual' e o 'mundano', entre o 'extraordinário' e o 'cotidiano'. Iconicamente representadas pela encruzilhada enquanto morada do 'povo da rua', as estórias narram não só um entrecruzamento de tempo e espaço, mas também uma abertura de possibilidades interpretativas." [CARDOSO, 2007a, p. 324].

28 "To avoid rejection some of us conform to the values of the culture, push the unacceptable parts into the shadows. [...] Yet still others of us take another step: we try to waken the Shadow-Beast inside us." [ANZALDÚA, 2012, p. 19].

29 "O ato de escrever é um ato de criar alma, alquimia. É a busca de um eu, do centro do eu, o qual nós mulheres de cor somos levadas a pensar como "outro" - o escuro, o feminino. [...] A escrita é uma ferramenta para penetrar naquele mistério, mas também nos protege, nos dá um distanciamento, nos ajuda a sobreviver." [ANZALDÚA, 2000 [1980], p. 232-233].

30 Referência à exposição online da artista Jota Mombaça, Atravessar a Grande Noite Sem Acender a Luz, junto ao Centro Cultural São Paulo, em 2021. Disponível em http:/ / www.centrocultural.sp.gov.br/jota-mombaca/. Acesso em 4/12/2021. 31 cf. BUARQUE DE HOLLANDA, 2019.

32 "A border is a dividing line, a narrow strip along a steep edge. A borderland is a vague and undetermined place created by the emotional residue of an unnatural boundary. It is in a constant state of transition. The prohibited and forbidden are its inhabitants. Los atravesados live here: the squint-eyed, the perverse, the queer, the troublesome, the mongrel, the mulato, the half-breed, the half dead; in short, those who cross over, pass over, and go through the confines of the "normal". [ANZALDÚA, 2019 [1987], p. 3]
33 "Somos o povo que salta no escuro, somos o povo no colo dos deuses". [ANZALDÚA, 2019 [1987], p. 327]

34 Gravação de relato oral de Laicon no terreiro, fevereiro/2020.

35 Categoria corrente na cena LGBT local, que abarca homens gays "não efeminados" e que são, supostamente, apenas "ativos", ou ainda homens heterossexuais que somente têm relações com outros homens às escondidas, não afetando o seu estatuto social hétero.

36 Retomando Deleuze e Guattari - que falam de "uma literatura menor" a respeito de Kafka -, Didi-Huberman postula a existência de uma "luz menor" que possuiria os mesmos aspectos filosóficos, notadamente o seu aspecto políitico, imanente e desterritorializante [DIDI-HUBERMAN, 2011, p. 52].

37 "A imagem é lucciola das intermitências passageiras; o horizonte banha na luce dos estados definitivos, tempos paralisados do totalitarismo ou tempos acabados do Juízo Final. [...] Os pequenos vagalumes dão forma e lampejo a nossa frágil imanência, os "ferozes projetores" da grande luz devoram toda forma e todo lampejo - toda diferença - na transcendência dos fins derradeiros. Dar exclusiva atenção ao horizonte é tornar-se incapaz de olhar a menor imagem." [DIDI-HUBERMAN, 2011, p. 115] 38 Tradução nossa do original: "[...] une façon d'habiter le monde pour un sujet nomade, clandestin, irrepérable et dont l'identité fugitive échappe à tout contrôle, à toute assignation à résidence et à identité." [MONDZAIN, 2012, p. 84]

39 Do original: "Survivance et revenance. Le survivre déborde à la fois le vivre et le mourir, les suppléant l'un et l'autre d'un sursaut et d'un sursis, arrêtant la mort et la vie à la fois, y mettant fin d'un arrêt décisiff, l'arrêt qui met un terme et l'arrêt qui condamne d'une sentence, d'un énoncé, d'une parole ou d'une surparole." [DERRIDA, 2003, p. 153] 
40 "Exu é o orixá iorubano que versa sobre os princípios da mobilidade, da transformação, das imprevisibilidades, das trocas, das linguagens, das comunicações e toda forma de ato criativo". [RUFINO, 2019, p. 115-116]

41 Sobre a concepção de Jean Rouch ao falar em "cinema-verdade" [DELEUZE, 2005, p. 183].

42 cf. SERGE MARGEL, 2017, p. 141- 170.

43 No terreiro de Jairo, além da umbanda, também é praticado o tambor de mina, religião afro-brasileira que cultua voduns forças da natureza e antepassados humanos divinizados -, orixás e encantados ou caboclos, que são espíritos de reis, nobres indígenas, turcos, boiadeiros, marinheiros etc. Diz-se que os encantados foram pessoas que, ao morrer, desapareceram, isto é, "se encantaram". Herondina, uma cabocla de origem turca, é uma das entidades de frente do terreiro e do pai de santo.

44 Tradução nossa, a partir da versão em língua inglesa [ROUCH, 2003 [1973], p. 96].

45 Serge Margel reflete sobre o cinema "protético e não mais mimético, que produz um fenômeno de transe, que Rouch nomeia justamente 'cine-transe'", relacionando-o à ideia de antropofagia [MARGEL, 2017, p. 95].

46 "I have been able to free myself of the weight of filmic and ethnographic theories necessary to rediscover the barbarie de l'invention." [ROUCH, 2003 [1973], p. 100].

47 Brasil é o país com o quinto maior número de assassinatos por homo e transfobia do mundo, e aqui a expectativa de vida de uma mulher trans gravita em torno dos 35 anos.

48 " [...] Assim, as normas de gênero mediante as quais compreendo a mim mesma e a minha capacidade de sobrevivência não são estipuladas unicamente por mim. Já estou nas mãos do outro quando tento avaliar quem sou. Já estou me opondo a um mundo que nunca escolhi quando exerço minha agência.
Infere-se daí, então, que certos tipos de corpo parecerão mais precariamente que outros, dependendo de que versões do corpo, ou da morfologia em geral, apoiam ou endossam a ideia da vida humana digna de proteção, amparo, subsistência e luto." [BUTLER, 2018, p. 85]

49 Referência a uma cena do filme em realização, presente no teaser [nota \#9]: as gays estão juntas, bebendo e conversando, como quase todas as noites na frente do terreiro. Quinho, cujas habilidades fabulativas se destacam no grupo, rouba o caderno de uma delas e inventa uma história sobre uma bixa feia [Laicon] que pede ajuda a uma cegonha para ir embora de seu povoado [Tonantins], pedindo que ela a leve para algum lugar fino, como Cancun ou Dubai. A cegonha se dispõe a ajudá-la, mas por ser muito velha e ter apenas três penas, elas acabam caindo num macaxeiral. Diante da frustração, a bixa resolve ficar com o problema e diz: "Quer saber, então vou pra Tabatinga, lá vai ser minha vida, ali vou fazer fama!". 
ANZALDÚA, Gloria. Borderlands/La Frontera: the new mestiza. São Francisco: Aunt Lute Books, 2012

ANZALDÚA, Gloria. Falando em línguas: uma carta para as mulheres escritoras do terceiro mundo. Revista Estudos Feministas, Florianópolis, v.8, n.1, 2000 [1980]. p. 229-236.

ANZALDÚA, Gloria. La conciencia de la mestiza/ Rumo a uma nova consciência. In HOLLANDA, Heloísa Buarque [Org.]. Pensamento feminista: conceitos fundamentais. Rio de Janeiro: Bazar do tempo, 2019 [1987]. p. 323-339.

BENJAMIN, Walter. O narrador. In BENJAMIN, Walter. Magia e técnica, arte e política. $3^{a}$ edição. São Paulo: Brasiliense, 1987 [1936]. p. 197-221.

BENJAMIN, Walter. Sobre o conceito de história. In BENJAMIN, Walter. Magia e técnica, arte e política. $3^{a}$ edição. São Paulo: Brasiliense, 1987 [1940]. p. 222-232.

BUARQUE DE HOLLANDA, Heloísa. Introdução. In HOLLANDA, Heloísa Buarque [Org.]. Pensamento feminista: conceitos fundamentais. Rio de Janeiro: Bazar do tempo, 2019. p. 9-21.

BUTLER, Judith. Corpos que importam: os limites discursivos do sexo. São Paulo: N-1 edições, 2019.

BUTLER, Judith. Quadros de guerra: quando a vida é passível de luto? Rio de Janeiro: Civilização Brasileira, 2018.

BUTLER, Judith. Problemas de gênero: feminismo e subversão da identidade. Rio de Janeiro: Civilização Brasileira, 2003. 
CARDOSO, Vânia Zikán. Marias: a individuação biográfica e o poder das estórias. In GONÇALVES, Marco Antonio; MARQUES, Roberto; CARDOSO, Vânia Zikán [Orgs.]. Etnobiografia: subjetivação e etnografia. Rio de Janeiro: 7 Letras, 2012. p. 9-18.

CARDOSO, Vânia Zikán. Narrar o mundo: Estórias do "povo da rua" e a narração do imprevisível. Mana, v. 13, n. 2, 2007a. p. 317-345. Disponível em http://dx.doi.org/10.1590/S0104-93132007000200002 Acesso em $4 / 12 / 2021$.

CARDOSO, Vânia Zikán. O Espírito da Performance. I/ha-Revista de Antropologia, v. 9, 2007b. p. 197-213

CARSTEN, Janet, Cultures of Relatedness: New Approaches to the Study of Kinship. Cambridge: Cambridge University Press, 2000.

CRAPANZANO, Vincent. Horizontes imaginativos e o aquém e o além. Revista de Antropologia, vol. 48, n.1, São Paulo, 2005. p. 363-384.

DA SILVA, Reginaldo Conceição. "NA GIRA DA UMBANDA": Exercício etnográfico sobre expressões de Afrorreligiosidade na "fronteira" e no Terreiro da Cabocla Jurema em Tabatinga, Amazonas. 2015. Dissertação [Mestrado em Cartografia Social] - Programa de Pós-Graduação em Cartografia Social e Política da Amazônia, Centro de Ciências Sociais Aplicadas, Universidade Estadual do Maranhão, Maranhão, 2015.

DAS, Veena. Life and words: violence and the descente into the ordinary. Berkeley, Los Angeles, London: University of California Press, 2007.

DELEUZE, Gilles. A Imagem-Tempo. São Paulo: Brasiliense, 2005.

DERRIDA, Jacques. Aprender finalmente a viver. Tradução de Fernanda Bernardo. Coimbra: Ariadne Editora, 2005.

Revista Poiésis, Niterói, v. 23, n. 39, p. 18-54, jan./jun. 2022. [DOl: https://doi.org/10.22409/poiesis.v23i39.52941] 
DERRIDA, Jacques. Living on/Border Lines. In BLOOM, Harold; MAN, Paul de; DERRIDA, Jacques; HARTMAN, Geoffrey; MILLER, Hillis. [Orgs.]. Deconstruction and criticism. London: Continuum, 1979. p. 62-142.

DERRIDA, Jacques. Parages. Paris: Galilée, 2003.

DIDI-HUBERMAN, Georges. Sobrevivência dos vaga-lumes. Belo Horizonte: Editora da Universidade Federal de Minas Gerais, 2011.

FACINA, Adriana; SILVA, Daniel N.; LOPES, Adriana C. Sobrevivência, linguagem e diferença: política no tempo do agora. In LOPES, Adriana C.; FACINA, Adriana; SILVA, Daniel N. [Orgs.]. Nó em pingo d'água: sobrevivência, cultura e linguagem. Rio de Janeiro: Mórula Editorial; Florianópolis: Editora Insular, 2019. p. 15-30.

HARAWAY, Donna. Manifesto ciborgue: ciência, tecnologia e feminismo-socialista no final do século XX. In HOLLANDA, Heloísa Buarque [Org.]. Pensamento feminista: conceitos fundamentais. Rio de Janeiro: Bazar do tempo, 2019 [1991]. p. 157-213.

HARAWAY, Donna. Staying with the Trouble: Making Kin in the Chthulucene. Durham: Duke University Press, 2016.

LORDE, Audre. Sou sua irmã: escritos reunidos São Paulo: Ubu, 2020.

MARGEL, Serge. Arqueologias do fantasma: [técnica, cinema, etnografia, arquivo]. Belo Horizonte, Relicário Edições, 2017.

MARTINS, Leda. Performances da oralitura: corpo, lugar da memória. Letras. Revista do Programa de Pós-Graduação em Letras. Universidade de Santa Maria. n. 26. junho de 2003. p. 63-81.

MONDZAIN, Marie-José. L'image zonarde ou la liberté clandestine. In COMITÊ BRASILEIRO DE HISTÓRIA DA ARTE. 2012. Brasília. Anais do XXXII Colóquio do [...]. Brasília: Universidade de Brasília, outubro de 2012. p. 83-107.

FREITAS, Camila; OLIVAR, José Miguel. imagem trans: transe, fabulação e sobre vivências na fronteira. 
OLIVAR, José Miguel. Adolescentes e Jovens nos Mercados do Sexo na Tríplice Fronteira Brasil, Peru, Colômbia: Três Experiências, um Tour de force e Algumas Reflexões. Revista Ártemis, v. 18, 2014. p. 87-102.

OLIVAR, José Miguel. Através do limite: diferenciação, relação e práticas de cuidado em contextos críticos na fronteira Amazônica - ênfase em sexualidade, gênero, ciclos de vida e etnia. - FAPESP número 2019/01714-3

OLIVAR, José Miguel. 'Ser mais'. tecnologias do crescer através do terreiro do Pai Jairo. Trabalho apresentado no 30 Seminário Casa, Corpo e Políticas da Terra. Programa de Pós-Graduação em Estado e Sociedade, Universidade Federal do Sul da Bahia, Porto Seguro, 18 a 20 de setembro de 2019.

PRANDI, Reginaldo. O candomblé e o tempo: concepções de tempo, saber e autoridade da África para as religiões afro-brasileiras. Revista Brasileira de Ciências Sociais, v. 16, 2001. p. 43-58.

PRECIADO, Paul B. un appartement sur Uranus. Paris: Grasset, 2019.

PRECIADO, Paul B. Testo Junkie. Sexo, drogas e biopolítica na era farmacopornográfica. São Paulo: N-1 edições, 2018.

ROUCH, Jean. Ciné-ethnography / Jean Rouch. Traduzido e editado por Steven Feld. University of Minnesota, 2003.

RUFINO, Luiz. Exu e a pedagogia das encruzilhadas. In LOPES, Adriana C.; FACINA, Adriana; SILVA, Daniel N. [Orgs.]. Nó em Pingo d'água: sobrevivência, cultura e linguagem. Rio de Janeiro: Mórula; Florianópolis: Insular, 2019.

SZTUTMAN, Renato. Reativar a feitiçaria e outras receitas de resistência - pensando com Isabelle Stengers. Revista do Instituto de Estudos Brasileiros. n. 69, abril de 2018. p. 338-360. 


\section{A ARTE BRASILEIRA NÃO SE RESUME AO EIXO RIO DE JANEIRO - SÃO PAULO: SOTAQUES POÉTICOS DO NORDESTE POR UMA URGENTE HISTÓRIA DA ARTE}

Brazilian art is not limited to the axis Rio de Janeiro - São Paulo: poetic accents from the Northeast for an urgent history of art

El arte brasileño no se limita al eje Río de Janeiro - São Paulo: acentos poéticos del Nordeste para una historia urgente del arte

Eduardo Bruno [Universidade Federal do Pará, UFPA] ${ }^{*}$

João Paulo Lima [Universidade Federal do Ceará, UFC] * *

Waldírio Castro [Universidade Estadual do Ceará, UECE] ***

BRUNO, Eduardo; LIMA, João Paulo; CASTRO, Waldírio. Revista Poiésis, Niterói, v. 23 , n. 39 , p. 55-72, jan./jun. 2022. [DOl: https://doi. org/10.22409/poiesis.v23i39.52943]

Este documento é distribuído nos termos da licença Creative Commons Atribuição Não Comercial 4.0 Internacional (CC-BYNC) (c) 2022 Eduardo Bruno, João Paulo Lima, Waldírio Castro.
RESUMO Esse texto, a partir da apropriação do termo sotaque do campo da linguística, aposta na dimensão plural da produção artística contemporânea do/no nordeste brasileiro, com o objetivo de estabelecer rupturas na/com a história da arte nacional, tradicionalmente narrada a partir do eixo Rio de Janeiro/São Paulo. Para tal, divido em três tópicos, que podem ser lidos na ordem que se preferir, o texto costura reflexões acerca do lugar do nordeste no sistema de arte nacional, com debates históricos, poéticos, estéticos, políticos e sociais que se estabelecem entre as regiões nordeste e sudeste. Sendo assim, cada parte do texto, mobiliza um escopo de referências teóricas e artísticas, provocando a ideia de sotaques poéticos para demarcar territórios propositivos para a formulação de muitos (outros) mapas (im) possíveis da arte brasileira.

PALAVRAS-CHAVE Sotaque poético; arte brasileira; nordeste brasileiro.

RESUMEN Este texto se centra en la dimensión plural de la producción artística contemporánea del nordeste brasileño, a partir de la apropiación del término "acento" del campo de la lingüística. Busca establecer rupturas en/con la historia del arte nacional, tradicionalmente narrada por Río de Janeiro/São

* Eduardo Bruno é doutorando em Artes na UFPA com bolsa FAPESPA. E-mail: eduardobfreitas@hotmail.com

* * João Paulo Lima é artista-performer-educador, escritor e Mestre em Literatura Comparada pela UFC. E-mail: castro.waldirio@gmail.com *** Waldírio Castro é artista transdisciplinar, arte educador, curador, produtor e mestrando em Artes da UFC. E-mail: jp.movimentos@gmail.com

Revista Poiésis, Niterói, v. 23, n. 39, p. 55-72, jan./jun. 2022. [DOl: https://doi.org/10.22409/poiesis.v23i39.52943] 
Paulo. Dividido en tres temas que pueden leerse en el orden que se prefiera, hilvana las reflexiones sobre el lugar del noreste en el sistema artístico nacional, con los debates históricos, poéticos, estéticos, políticos y sociales que se establecen entre las regiones del noreste y del sureste. Además, cada parte del texto moviliza un ámbito de referencias teóricas y artísticas y provoca la idea de acentos poéticos para demarcar territorios propositivos para la formulación de muchos otros (im)posibles mapas del arte brasileño.

PALABRAS CLAVE Acento Poético, Arte brasileña Nordeste brasileño

ABSTRACT This text bets on the plural dimension of contemporary artistic production from/in the Brazilian northeast, based on the appropriation of the term "accent" from the field of linguistics. It aims to establish ruptures in the history of national art, traditionally narrated by Rio de Janeiro/São Paulo. Thus, it is divided into three topics that can be read in any order one prefers, and it sews reflections about the place of the Northeast in the national art system, with historical, poetic, aesthetic, political and social debates that are established between the Northeast and the Southeast regions. Moreover, each part of the text mobilizes a scope of theoretical and artistic references, provoking the idea of poetic accents to demarcate propositional territories for the formulation of many (other) (im)possible maps of Brazilian art.

KEYWORDS Poetic accent; Brazilian art; Brazilian northeastern 
Esse texto é um labirinto. Uma armadilha armada não para responder às históricas falácias da história da arte no Brasil. Como bom labirinto, não pretendemos apresentar respostas, pois não há. Qualquer tentativa de resposta seria mais uma outra falácia, uma caricatura, um reducionismo criado e construído para aprisionar nossas diversas identidades. Nesse sentido, propomos que visualizemos o mapa do Brasil por outra cartografia, relocalizando as proximidades e lonjuras que constituíram essas gentes. Contudo, sempre partindo do plural como referência, dos diversos sotaques, seja com o /s/vozeado ou não.

Sendo assim, esse texto aposta na dimensão do sotaque, numa apropriação conceitual de um termo da linguística que é usado para designar os modos como cada falante de uma língua faz uso dela ao seu modo e ao modo de pequenos grupos que se inserem no contínuo de uma população. Sotaques poéticos do Nordeste. Sim, nós temos sotaques, e vocês, não têm?

\section{É por esses sotaques que nos comparam e/ou} desamparam, que decidimos alinhavar nossos textos no risco de encontrar e/ou desencontrar nossas escritas. É pela compreensão das diversas poéticas que apontamos nosso olhar acerca dos nossos sotaques, demarcando territórios possiveis e propositivos no intuito de provocarmos muitos [outros] mapas [im]possíveis.

\section{SOTAQUE 1 - DAS POÉTICAS PERFORMATIVAS}

Que historicamente o povo nordestino, devido a diversas questões, entre elas o empobrecimento estratégico da região em decorrência do escoamento das riquezas para região do sudeste, foi forçado a migrar principalmente para São Paulo e Rio de Janeiro, já é de conhecimento de todos. Uma simples tarde assistindo a televisão brasileira, principalmente no fim de semana, podemos ver como a pobreza nordestina vem sendo espetacularizada e rentabilizada. De Gugu Liberato a Luciano Huck, o nordestino, seja na tentativa de voltar para sua terra ou na necessidade de ter uma moradia digna, vem sendo apresentado e construído pela mídia hegemônica como o pobre, uma vítima da seca que migra para o sudeste na busca do sucesso, ou seja, toda uma formulação do que a escritora Chimamanda Ngozi Adichie nomeia enquanto história única [2019] criada para designar um povo.

As riquezas do país, principalmente com a chegada da Corte portuguesa no Brasil, vêm sendo escoadas para a região sudeste há bastante tempo, ou seja, o pobre que hoje diverte as tardes de domingo vem sendo forjado por meio de uma desigualdade social historicamente construída. Desigualdade essa que não apenas constrói/ construiu o processo de migração do nordestino para o Sudeste, mas também fetichiza, planifica 
e formula estereótipos, "e o problema com os estereótipos não é que sejam mentira, mas que são incompletos. Eles fazem com que uma história se torne a única história" [ADICHIE, 2019, p. 26].

Esse cenário não seria diferente na perspectiva das artes. Pertinente lembrarmos que, o que é ensinado [desde do fundamental até a universidade] enquanto história da arte brasileira, na maior parte, não passa da história da arte do sudeste brasileiro sendo narrada/tomada como história da arte nacional. Entre Café com Leite, Jardins e Leblon, muito se sabe e se conta sobre as perspectivas da arte sudestina enquanto um sinônimo do que se entende como história da arte no Brasil. Muito se sabe, por exemplo, sobre a Semana de Arte Moderna, de 1922, que ocorreu em São Paulo-SP, mas pouco, ou quase nada se sabe/fala sobre a Padaria Espiritual, de 1892, que ocorreu em Fortaleza-CE.

Contudo, não queremos cair na generalização homogeneizada sobre a formulação da história da arte brasileira apenas em um viés de geolocalização, sabemos que, mesmo nessa formulação da arte brasileira concentrada a partir do sudeste, há toda uma maquinação para se produzir uma identidade artística nacional com base em uma construção branca-cisgênera-heterossexual-capacitista-classista. A contrapelo disto, o pensamento que estamos mobilizando nesse texto aciona fazeres e teorizas [práxis] em arte que relacionam a geolocalização da produção nordestina, mas não com o objetivo de responder ao modelo hegemônico da figura da identidade artista nacional. Nossa provocação para uma outra história da arte brasileira parte de uma outra formulação da história, um outro tempo e um outro espaço. Uma perspectiva diferente da dominante, não como uma contradição a esta, mas uma história que é própria em si.

Quando escolhemos sobre o que falar em uma formulação histórica, definimos quais são as obras relevantes para serem lembradas, ao passo que relegamos todas as outras produções ao esquecimento institucionalizado. A formulação de uma história a ser contada acontece na relação com o poder vigente e os interesses sociais em curso, "é impossível falar sobre história única sem falar sobre poder [...] o poder é a habilidade não a penas de contar a história de outra pessoa, mas de fazer que ela seja sua história definitiva" [ADICHIE, 2019, p. 23]. Com isto, a longa lista da exclusão de artistas nordestinos, principalmente aqueles que não correspondem ao processo da formação de uma ideologia dominante branca-cisgênera-heterossexual-capacitista-classista, se dá também como uma forma de possibilitar a reprodução do poder hegemônico e manter os locais de privilégios no país. 
Nesse sentido, apontamos que na esteira das perspectivas das tecnologias de exclusão e silenciamento, no caso do Brasil, é ingênuo não pensar na relevância da geolocalização como mais uma forma de se maquinar uma identidade nacional que privilegia e aciona lugares de poder a poucos. Ainda temos uma produção de conhecimento institucionalizado, não apenas em arte, muito concentrado no sudeste do país, lá estão as universidades mais antigas e que historicamente possuem o maior investimento, é também nessa região onde se tem a maior concentração de renda, além do poder de influenciar a política nacional. Talvez, por questões como essas, entre outras, é que a geolocalização, como estratégia de formulação de um lugar de privilégio, ainda seja pouco ou quase nunca discutida de forma transversal nos espaços de poder.

Em detrimento de uma concentração de fluxos de mercadoria, pessoas e poder político/econômico, historicamente formulado, a região sudeste, principalmente Rio de Janeiro e São Paulo, foi/é o local que vem conseguindo se desenvolver, de modo mais rápido, aos moldes da modernização ocidental. De um ponto de vista material, se os meios de produção, historicamente, já estavam sendo construídos no sudeste, o escoamento econômico do país já vem ocorrendo há bastante tempo para a região, construindo, assim, uma elite econômica, nada mais natural que as grandes cidades nacionais estejam inseridas na região sudeste do país. Desta forma, em uma corrida desigual, devido a inúmeros processos históricos, criou-se todo um cenário para que os demais moradores do Brasil, principalmente os nordestinos, alimentassem o sonho de conseguir "descer" para tentar o sucesso no sudeste, assim como aponta a composição musical, "Carneiro", de 1974, dos artistas fortalezenses Ednardo e Augusto Pontes:



O sonho de ir embora para o Sudeste, nem que seja por meio da sorte de ganhar no jogo do bicho, circula o desejo nordestino quase como um fantasma. A ida ao sudeste, deslocando-se para o eixo de privilégio do país, ainda hoje, paira como uma histórica única de sucesso para o nordestino. Uma experiência de deslocamento que, 
quando "conquistaram", vem junto com o estereótipo e planificação das identidades nordestinas: nordestino em São Paulo é paraíba e no Rio de Janeiro é baiano. Um vício de linguagem histórico, mas que até hoje é usado para designar "esse povo que tem sotaque cantando".

O perigo de percebermos nossas identidades por meio de uma estrutura de poder que condiciona a geolocalização como justificativa para a formulação pasteurizada das identidades a partir do olhar do local de privilégio, é sermos cooptados pela ideia de que é possível envelopar toda uma população e seus fazeres culturais a partir de uma categoria imposta. Entretanto, como estratégia de fabricação de alianças [BUTLER, 2018], podemos articular o fato de sermos lidos como nordestinos para profanar ${ }^{1}$ essa nomeação a partir do reconhecimento do processo histórico que nos subalternizou a uma estrutura de poder e, assim, nos organizarmos para destituir essa estrutura historicamente estabelecida.

Nesse sentido, apostando na dimensão do sotaque como uma forma de fugir da homogeneização historicamente imposta aos nossos corpos e produções artísticas, afirmamos a diferença presente nas poéticas geolocalizadas no nordeste brasileiro. Se nossos sotaques sempre foram usados como forma de sermos apontados como o outro, nos apropria- mos dessa dimensão do sotaque para afirmarmos nossas diversas poéticas, estéticas e políticas. Destacar a produção de artistas locais [nordestinos] que operam ações em arte que deslocam o olhar para poéticas que surgem de outras centralidades de mundo e narrativas, a partir da experiência construída com seus corpos e comunidades, é também perverter a ideia de nordestino sem abandonar a necessidade de apontar o apagamento histórico da produção artística local.

Com isto, entre alguns artistas do cenário contemporâneo nordestino, apontar o trabalho de Maria Macedo, artista cearense que nasceu no distrito de Quitaiús do município de Lavras da Mangabeira-CE, é acessar a poética de uma artista nordestina que opera suas criações ao passo que afirma os seus e seu entorno, desviando da ideia sine qua non de que para produzir arte é necessário se deslocar para os eixos de "privilégio". Dentro da extensa produção de Macedo, destacamos o projeto "Dança para um futuro cego" [2021], trabalho que hibridiza performance, fotografia e vídeo. Nessa obra, o corpo preto de Maria Macedo, vestido em vermelho, juntamente a paisagem do sertão do Ceará e objetos como facão, pote de barro e prato de louça branca, ao passo que mobiliza imagens e performatividades acerca do sertão, rompe com os visíveis pré-estabelecidos para a região. Acessar 
esse trabalho é um exercício urgente de percepção acerca de narrativas outras, de sotaques poéticos que estão em curso rompendo com os possíveis impostos aos corpos nordestinos em suas interseccionalidades [AKOTIRENE, 2019].

"[des]Ordem e re[Pro]gresso", que teve sua primeira execução em 2018 na primeira edição do Festival de Performance do Ceará: Imaginários Urbanos². Em uma ação que a olhos rápidos pode passar despercebida, Lívio senta-se em um tamborete de plástico, na Praça do


Ferreira, localizada na cidade de Fortaleza/ CE, para, com linhas vermelhas, costurar os retalhos do que antes era uma bandeira brasileira. Ao final, a bandeira é "hasteada" em uma pequena árvore da praça.

Tais sotaques poéticos do nordeste, localizados no Ceará, na região do Cariri, fazem parte desse caleidoscópio da diferença que ressoa com tantas outras produções artísticas nordestinas. Cada um, longe de uma harmonia, produz em arte suas questões e mobiliza os materiais e os suportes que Ihes parecem necessários. Com isto, olhar para estas e tantas outras obras produzidas por artistas do nordeste é um exercício de ruptura

Revista Poiésis, Niterói, v. 23, n. 39, p. 55-72, jan./jun. 2022. [DOl: https://doi.org/10.22409/poiesis.v23i39.52943] 
gente feia, mais escura e morta de fome. Ainda há essa imagem de nós de como os lá de cima? Ironia. Foda-se. Nossos/tSi/e /Ti/ se misturam e reverberamos em narrativas nossas histórias semelhantes de experiências de xenofobia e regionalismos.

Do lado de cá, de cima, tudo tem sido mais pobre. Não há mais tantos auxílios sociais. Abismos, muitos, mais gente na rua e mais miseráveis da seca e da cerca, ambas historicamente sustentadas pela decisão de um tal imperador que se traslada da Bahia para "construir" a sede do reino brasiluso. A lusofonia débil na terrabrasilis se instaura na cidade do Rio de Janeiro e o Nordeste começa a perceber o arame farpado que ratificará nosso lugar de exclusão. Pra sempre? Depois de Minas há a Bahia, depois tudo é Nordeste. Ouvia isso desde menino de parentes que foram morar pelo Sul. Até os apelidos dados generalizam a espécie brasileira xingada: ei, paraíba! Sai da frente, bahiano! E por aí foi e vai nossos ecos de um Brasil "cordialmente" excludente [HOLANDA, 1998] que retroalimenta a superioridade sul-sudeste $X$ norte-nordeste.

De repente, deparo-me com o texto de um conterrâneo cearense, Thiago Florêncio, intitulado propositalmente "Nativo ausente". Na sua escrita, cita-se as "feridas sutis" lembradas por Nietzsche e menciona a mexicana Gloria Anzaldua, para quem a fronteira EUA/MÉXICO é uma ferida aberta em que o primeiro mundo atrita o terceiro e sangra.

Decido olhar o mapa do Brasil pelo google maps e imagino a ferida no meu mapa individual e periférico.

Onde começa a ferida do Brasil que vibra uma dor? Por onde começar a sutura? De onde e quando a gente resolve se boicotar e criar uma ferida entre norte e sul e mapearmos quem é mais ou menos gente, mais ou menos brasileiro, mais ou menos nativo, de fala melhor ou pior? Quem começou a dizer que o outro é que fala errado, que o sotaque do outro é que é feio, estranho, bizarro, engraçado ou dissimuladamente: bonitinho!

Estamos por aqui no Norte espalhando alegria e tristeza, excesso de recursos e escassez de investimentos. Aos olhos de boa parte da população sudestina ainda somos sustentados pelo povo que trabalha, sabemos apenas fazer festa e ter filhos. Que somos preguiçosos e burros da cabeça chata. Parece mentira, mas as frases são ainda motivo de chacota e zoeira, sim. E por que não espontaneidades sincera quando viramos motivos de piada na TV, no cinema ou nos turismos Brasil afora.

Nossos sotaques têm se misturado mais, conversado e criado um território afim, a fim de suturar as feridas entre o que a geopolítica de homens cis brancos criou. Os sotaques são fronteiras líqui- 
das que nem cercas, rios, serrotes, pontes, muros conseguem desgrudar. Nossa fonética vai se resvalando e criando outros modos e pontos de articulação, amalgamam nossos sons de ancestralidades, os sons que sobram do sangue derramado pelo europeu que pensou ter vencido o que não é matado. Sotaque é corpo, é subjetividade, é identidade. Os sons aspirados, fricativos, sibilantes, oclusivos, todos de norte a sul desse país não foram ganhos de acentos europeus, mas de uma cor mais escura, ninado no colo das mulheres indígenas e nas tetas das mães pretas. Herdamos, cantamos e dançamos o que é cafuso-caboclo, mameluco, afro,indígena e liquidamos com to da a tentativa de cerceamento que ainda nos impõem uma regra da gramática do português padrão. Ou patrão?

Se andarmos pelos territórios das artes nossas supostas fronteiras se liquidificaram ainda mais. Nossas trocas e percepções de si tem ido pra frente sem deixar de olhar pra trás na tentativa de não vacilar mais para a construção de uma história mais presente, mais possuída, desfeita de autorizações de outrem. Criamos nossas pontes mais largas e túneis profundos para fugir, desviar do que o eixo sul parecia por décadas vociferar como únicas verdades estéticas.

O exemplo disso sempre foi a literatura cearense, desde o século 19, quando tudo já havia sido trasla- dado para o eixo mais sudestino, autores e autoras foram se constituindo escritores de grande relevância para a criação literária nacional. Não fosse autores cearenses, a literatura realista-naturalista se ressentiria de personagens-tipos para compor o quadro de nossas influências deterministas bem casadas com a miséria dos retirantes e das paisagens ásperas do sertão do Ceará.

Mas não ficamos por aí. A literatura contemporânea cearense [aqui cito o Ceará por ser meu estado natal] se envereda por uma escrita experimental, disruptiva e desconcertante. Escritoras mulheres se destacam, escritores negros periféricos, espaços da linguagem da escrita que sempre ousaram mesmo se tratando da província do Siará-Grande.

Autoras como Sara Síntique, Nina Rise, Nádia Fabrici, Argentina Castro, Vitória Régia, Anna K Lima e Mika Andrade se reúnem e catalogam contos eróticos de jovens autoras cearenses e ampliam com "O Olho de Lilith" a literatura com seu olhar sempre predecessor. Numa país-região-estado-cidade, onde o machismo ainda prepondera e nos remete à mulher que precisa recorrer à figura do macho para ser vista mais forte, jovens escritoras extrapolam o purismo acadêmico e poetizam suas "escrevivências" para reescrever a la Conceição Evaristo modos de gritar "isso aqui também é nosso" e rompem no cenário litero-brasileiro suas provocações porosas. 
Não diferente, autores como Talles Azigon também "lançam mão" de suas composições e escolhem capturar olhares sobre cidade, periferia, corpo gay, corpo negro, homoafetividades e denúncia para construir uma trilogia literária de poesias periféricas publicadas como o nome de "Sarau" e lançada, recentemente, pela editora Substância [Fortaleza-CE]. Mesma editora por onde publiquei meu recente livro "Viço, Manco, Voo", que enquanto um escritor def-gay-nordestino-negro se vê nesse des-cânone, em que a dissidência e lírica periférica desbrava outras extensões possíveis para o campo literário.

Tudo isso acontece porque há uma necessidade cada vez mais incitante de nos conectarmos, "mas conectar é verbo transitivo direto que, de forma bem mais ampla, representa a agregação de diversos elementos em busca de objetivos comuns. Reconectar, neste sentido, é refazer conexões que foram perdidas." [RUFINO, 2020]. Refazer o que está perdido pela colonização e recolonização, pelo afastamento, pela permanência das desoportunidades, pela divisão ilegal e injusta de riquezas, pelo olhar que empobrece mais que enleva os que estão - contraditoriamente- na parte de cima do mapa. E não só reconectar o Nordeste em si, mas o país que precisa se reformular, removimentar e mover os lugares horizontalmente para nos vermos e enxergarmos melhor [es].

\section{SOTAQUE 3 - DAS POÉTICAS QUEERS}

Uma das estratégias utilizadas para fabricar a ideia de centralidade da região sudeste na mídia hegemônica é a ficção de neutralizar o sotaque. Com isso, ao se impor no centro, tudo que está na margem se estabelecerá como o diferente, o outro, o que não ocupa o centro. Ou seja, para estabelecer uma norma, e aqui, no caso, estamos apontando a fonética, é necessário tomar como referência do que se é ficcionalizado como normal, e, a partir desta referência, compreender/nomear o que não é normal/natural como o diferente, estranho, o outro, o anormal, como aponta Foucault [2014]. Desta forma, seja no jornalismo, na rádio ou nas novelas, criou-se a ficção de um sotaque neutro [que, na verdade, é paulista ou carioca] que deveria ser utilizado na mídia de forma a unificar/normalizar uma fonética na comunicação.

Tal construção de um sistema de representação ${ }^{3}$ [HALL, 2013], não apenas relacionada ao sotaque, mas também a diversos outros estereótipos, reforçados sobretudo na mídia hegemônica e na indústria cultural ${ }^{4}$ ao longo da história ${ }^{5}$, vêm impondo opacidade e discursos simplistas/preconceituosos em relação ao Nordeste. Assim, junto ao processo de uma suposta normalização da fonética a ser utilizada nacionalmente, diversos processos colonizadores de uma elite econômica, geográfica e cultural 
insistem em impor uma centralidade/protagonismo na construção de uma identidade nacional. Acerca de tais processos, parece pertinente apontarmos uma reflexão trazida pela autora Berenice Bento que afirma: "Se trocarmos a palavra "Nordeste" por "Brasil", teremos uma citação do que os europeus pensavam das culturas colonizadas que foram destruídas por eles." [BENTO, 2017, p. 176].

Desta forma, ao falarmos em sotaque, capturamos nesta escrita tal conceito para pensarmos a diferença. Vale destacar que o uso do conceito de diferença se distancia bastante do discurso neoliberal da diversidade, que torna genérico o complexo emaranhado que constitui a diferença. Para Miskolci [2020], o termo diversidade "é uma concepção de cultura muito fraca, na qual se pensa: há pessoas que destoam da média e devemos tolerá-las, mas cada um se mantém no seu quadrado e a cultura dominante permanece intocada por esse Outro" [p.51]. O autor acrescenta que a ideia de diversidade tenta manter intocada a cultura dominante sendo apenas tolerante com a diferença. É assim que os discursos da diversidade vão ganhando as propagandas e os programas de televisão, arquitetando a manutenção daqueles que se colocam no centro das narrativas hegemônicas. Viver, se relacionar e compreender o mundo com/pela diferença estabelece que o outro, o diferente, o que não está no cen- tro, nos atravesse, nos transforme e nos empreste suas lentes para enxergar o mundo de forma compartilhada compreendendo as diferenças de cada um/uma/ume. Ademais, no Nordeste, diferente do que a mídia hegemônica afirma, temos diferentes sotaques. Quem mora em Natal tem a fonética diferente de quem mora em Fortaleza, que tem a fonética diferente de quem mora em João Pessoa, assim por diante. Além da fonética, a construção social-política-colonizatória, mesmo que atravessada por sistemas de representação em comum, tem peculiaridades.

Dando continuidade às nossas reflexões, podemos destacar que, desviando ou construindo simbólicos outros, a diferença presente no Nordeste, que estamos chamando aqui de sotaque, está presente em diversas produções artísticas. Tais produções vêm rompendo pressupostos hegemônicos e reinventando o imaginário dos/das/des sujeitos/as/es nordestinos/as/es. Sobretudo nas poéticas dissidentes de gênero, sexualidade e corporeidade, que pela lente dos estudos queer ${ }^{6}$ podemos chamá-las de produções queer/transviadas, tais produções vêm reimaginando o Nordeste. Questões comumente direcionadas aos sujeitos nordestinos como a heterocentralidade, o machismo, o patriarcalismo e a religiosidade vêm sendo questionadas e reelaboradas por tais produções desviantes. 
Com isso, por meio da invenção de poéticas artísticas enquanto homem gay, artista-pesquisador, nordestino, nascido na cidade de Campina Grande - PB, nos últimos anos venho sendo atravessado pelas diversas reimaginações [MOMBAÇA, 2016] propostas por artistas contemporâneos da Paraíba. Neste recorte, destaco a produção de artistes paraibanes como Julian Santos ${ }^{7}$, Bixarte ${ }^{8}$, Val Donato ${ }^{9}$, a coletiva paraibana EKÈ Candomblé System ${ }^{10}$ que recentemente constitui a Ekè audiovisual, André da Costa Pinto ${ }^{11}$, entre tantes outres artistes desviantes. Artistes/artivistes com sotaques paraibanos que reafirmam a diferença e vêm tensionando o status quo hegemônico da hetero-cis-centralidade.

A partir disto, a arte parece nos mostrar um caminho para reinventar outras relações/agenciamentos exercitando inclusive a criação de outros mundos/simbólicos/ sistemas de representação. Unindo arte e ativismo

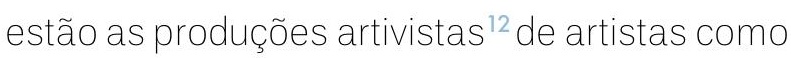
Julian Santos, multiartista paraibano, homem-trans que reimagina e inventa com seu sotaque paraibano prosódias por meio da música, questionando, denunciando e tensionando a cisnormatividade. Em suas músicas e poemas Julian desabafa e compartilha os embates que o corpo transmasculino sofre no cotidiano, como por exemplo na música "Sua mente sem preparo", onde ele questiona se é o corpo trans que está errado ou se é a mente imersa pela lente cisnormativa que está equivocada.


Imagem: Julian Santos em "Sua mente sem preparado" / Qr-Code

Em outro de seus trabalhos, Julian questiona acerca da sociedade falocentrada, que não compreende a existência de homens com vagina e que usam o termo "buceta" como xingamento para designar

Revista Poiésis, Niterói, v. 23, n. 39, p. 55-72, jan./jun. 2022. [DOl: https://doi.org/10.22409/poiesis.v23i39.52943] 
algum acontecimento ruim. No vídeo intitulado "Buceta"14, Julian tensiona o esperado hegemonicamente para o corpo masculino e, por meio do som de sua fala, usa seu sotaque/diferença para falar acerca do sexismo, do machismo, do falocentrismo e a ciscentralidade.

Retomando os atravessamentos acerca dos sotaques nordestinos, gostaria de compartilhar uma experiência que me provocou a construir a poética desta escrita. Ao morar na capital paulistana, entre 2013 e 2017, em busca de supostas oportunidades de trabalho como ator, fui fortemente atravessado pela ficção da centralidade sudestina. "Você não parece nordestino", "Ai que sotaque gostoso, fala de novo", "Nossa, não sabia que existia isso no nordeste", "Tenho um amigo que mora em Recife, Fulano, você conhece?". Essas são algumas das frases que escutei no período em que morei em São Paulo e me provocaram diversos questionamentos sobre o que vem sendo ou o que pode ser o Nordeste ou o/a/e nordestino/a/e.

com o tempo, tal processo violento de neutralidade/naturalização foi imposto sobre meu corpo/ fala. Escutando o que na época era considerado elogio pelos professores de fonoaudiologia: "Nossa!, quase não consigo perceber seu sotaque". Assim como o sotaque, meu processo de desidentificação com o Nordeste e o afastamen- to geográfico, foi tomando meu corpo/fala. Me tornei um personagem de mim mesmo, reforçado positivamente todos os dias pelos amigos e indústria cultural. Um paraibano fantasiado de paulista, perdido nos meus processos de busca por uma identidade.



Imagem: Alan Souza BRUNO, Eduardo; LIMA, João Paulo; CASTRO, Waldírio. A arte brasileira não se resume ao eixo Rio de Janeiro-São Paulo: sotaques poéticos.. 
Ao retornar para o Nordeste no final de 2017, agora na cidade de Fortaleza - CE, com uma realidade bem diferente da cidade de Campina Grande - PB, inclusive no sotaque, fui resgatando as alianças e os comuns do que eu compreendia enquanto Nordeste. Neste processo de reencontro retomo as memórias de minha cidade inventando uma pesquisa cênica chamada Rainha do Milho. Na experimentação cênica, áudios de crianças entrevistadas respondem à pergunta "Você já viu um menino usando vestido?". A partir deste questionamento e das memórias da/na infância, em que eu tinha o desejo de vestir e brincar com os trajes da Rainha do Milho, exercito questionar os binarismos que generificam até mesmo a indumentária.

\section{Enquanto artista-pesquisador, venho criando} diversos trabalhos artísticos e pesquisas acerca de como a lente de mundo hetero-cis-normativa vem ficcionalizando uma centralidade hegemônica. Apesar de nos últimos anos o sistema de arte vir capturando diversos lugares de invisibilização histórica como o ser nordestino, negro, periférico, LGBTQIA+, Def, entre outros, não estamos reduzidos ao que o centro nos categoriza. Ademais, enquanto artistes, nordestines atravessades pelas poéticas contemporâneas de dissidência, não inventamos obras de arte apenas com o objetivo de enfrentamento a qualquer ótica de mundo que se coloque no centro. Mais do que enfrentivos, estamos sendo propositivos, não apenas quando inventamos poéticas, mas também quando reimaginamos nossas práticas históricas e o papel, sobretudo, regional, que nos colocaram historicamente. Neste contexto, compreendendo as interseccionalidades [AKOTIRENE, 2019] geográficas, de gênero, sexualidade, raça, classe, corporalidade, e os sotaques/diferenças de cada localidade, podemos apontar que diversos artistes vêm exercitando em aliança, reelaborar, inventar/alargar o que vem sendo entendido como Nordeste.

NOTAS

1 A profanação implica, por sua vez, uma neutralização daquilo que profana. Depois de ter sido profanado, o que estava indisponível e separado perde a sua aura e acaba restituído ao uso [AGAMBEN, 2007, p. 68]. Então profanar é "desativar os dispositivos do poder e devolver ao uso comum os espaços que ele havia confiscado" [AGAMBEN, 2007, p.68].

2 O Festival Imaginários Urbanos é um festival de performance urbana que vem sendo realizado no estado do Ceará desde 2018. Em suas três últimas edições [2018,2020,2021], com curadoria de Eduardo Bruno, o festival é dividido em 3 eixos: 
processos formativos, mostra artística e publicação bibliográfica. Para mais informações, acessa o Instagram: https://www. instagram.com/imaginarios_arte/.

3 "representação é uma parte essencial do processo pelo qual os significados são produzidos e compartilhados entre os membros de uma cultura. Representar envolve o uso da linguagem, de signos e imagens que significam ou representam objetos" [p.32].

4 Como sugestão para uma discussão mais aprofundada acerca do conceito de indústria cultural, sugiro a leitura do artigo de LACOMBE [2019]. O Conceito de Indústria Cultural: Leituras na Contemporaneidade. Disponível em: http://entremeios.com. puc-rio.br/media/11\%20Lacombe\%2Oind.pdf

5 Como sugestão para aprofundamento das questões acerca da historicidade do nordeste, sugiro a leitura dos livros do autor Durval Muniz de Albuquerque Junior "A invenção do Nordeste e outras artes" e "Nordestino: Invenção do "falo" uma história do gênero masculino [1920-1940].

6 Os Estudos Queer, Cuir, Kuir, bixa, transviados, maricas, transmaricas se inventam enquanto agenciamento de diversos autores e pessoas desviantes as normas hegemônicas acerca dos regimes de poder e normatividade sobretudo no que diz respeito as questões de gênero, sexualidade e corporalidade. Compreendo como estudo e não teoria, pois são agenciamentos em constante construção e movimento e com abordagens diferentes, que muitas vezes, não dialogam entre si. Nos últimos anos, os Estudos Queer vêm elaborando, de uma forma mais vertical, acerca das questões de raça, localização geopolítica e classe, como por exemplo; nas proposições dos estudos Queer of color critique. Como primeiro disparador para uma genealogia dos estudos queer, sugiro o artigo "A teoria queer em uma perspectiva brasileira: Escritos para tempos de incertezas" do pesquisador
Arkley Marques Bandeira disponível em: https://periodicos.sbu. unicamp.br/ojs/index.php/rap/article/view/8654815

7 Paraibano, artivista, homem trans, bacharel em arte e mídia pela Universidade Federal de Campina Grande [UFCG], músico, artista e defensor de causas LGBTQ+

8 Poetisa, escritora, atriz e rapper, a artista paraibana Bixarte é uma expoente do Rap Paraibano.

9 Vocalista e compositora, destaque no cenário musical paraibano de forma solo e na banda 'Os Cabeças'.

10 Se intitula em sua página como uma Coletiva Ekè formada por bixas - afras - anarkas - futurísticas, que estão excitadas.

11 Cineasta paraibano idealizador do Comunicurtas - Festival de cinema de Campina Grande - PB. Ao longo de sua trajetória, em suas produções como "Amanda \& Monick", "Tudo que Deus Criou", "O tempo feliz que passou" e "Madame", o cineasta conta histórias reais e ficcionais de sujeitos desviantes de gênero, sexualidade, corporeidade, construindo imaginários outros acerca da Paraíba.

12 Podemos compreender artivismo como um movimento de artistas disruptivos, encontrados principalmente nas estéticas contemporâneas, que exercitam romper com os pressupostos normativos, e buscam materializar outros regimes de representação que estão à margem da norma.

13 Para utilizar o QR Code: 1 - Ter um aparelho celular com câmera. 2- Fazer o download de um aplicativo para leitura de QR Codes 3- Após instalado o aplicativo, basta abri-lo e aproximar a câmera do celular no QR Code, onde terá acesso a um link. 4 -Basta clicar no link pra ver/assistir.

14 Disponível em: https://www.youtube.com/watch? $v=a J$ SAyHiNgQA Acessado em 20 de outubro de 2021. 
ALMEIDA, Diogo; ALMEIDA, Luana. Artistas da Paraíba ressaltam a importância do Dia do Orgulho LGBTQ+. G1 Paraíba. Disponível em: https://g1.globo.com/pb/paraiba/noticia/2020/06/28/artistas-da-paraiba-ressaltam-a-importancia-do-dia-do-orgulho-Igbtq.ghtml Acessado em: 20 de outubro de 2021.

ALBUQUERQUE JUNIOR, Durval Muniz de. A invenção do Nordeste e outras artes. São Paulo: Cortez, 2011

ALBUQUERQUE JUNIOR, Durval Muniz de. Nordestino: Invenção do "falo" uma história do gênero masculino [1920-1940]. São Paulo. Intermeios, 2013.

AKOTIRENE, Carla. Interseccionalidade. São Paulo: Pólem, 2019.

ANDRADE. Mika. O olho de Lilith. Ferina. Fortaleza, 2019.

BANDEIRA, A. M. A teoria Queer em uma perspectiva brasileira: escritos para tempos de incertezas. Revista Arqueologia Pública, Campinas, SP, v. 13, n. 1[22], p. 34-53, 2019. Disponível em: https://periodicos.sbu. unicamp.br/ojs/index.php/rap/article/view/8654815. Acesso em: 21 out. 2021.

BENTO, Berenice.Transviad@s:gênero, sexualidade e direitos humanos. Salvador: EDUFBA, 2017.

BUTLER, Judith. Corpos em Aliança e a política das ruas: notas para uma teoria performativa de assembleia. Rio de Janeiro: Civilização brasileira, 2018.

CARULHA, Gabriel. Bixarte: As diversas faces de uma trans não binária dentro do Rap. Brasil de Fato Paraíba, 2019. Disponível em: https://www.brasildefatopb.com.br/2019/11/16/bixarte-as-diversas-faces-de-uma-trans-nao-binaria-dentro-do-rap Acessado em: 21 de outubro de 2021 
FLORENCIO. Thiago. Nativo Ausente. Rio de Janeiro. Imandaia, 2020

FOUCAULT, Michel. História da Sexualidade 1: A vontade de saber. Rio de Janeiro. Paz e Terra. 2014

HALL, Stuart. Cultura e Representação. Rio de Janeiro: Ed. PUC-Rio; Apicuri,2016.

HOLANDA. Sergio Buarque de. Raizes do Brasil. José Olímpio. São Paulo 1998.

LACOMBE, Fabiano. O Conceito de Indústria Cultural: Leituras na Contemporaneidade. Entremeios: Revista Discente do da Pós Graduação em Comunicação Social da PUC -Rio. Edição 15, vol 1, jan-jun/2019. Disponível em: http://entremeios.com.puc-rio.br/media/11\%20Lacombe\%20ind.pdf Acessado em: 20 de outubro de 2021.

MISKOLCI, Richard. Teoria Queer: Um aprendizado pelas diferenças. Belo Horizonte: Autêntica Editora; UFOP, 2020 .

MOMBAÇA, Jota. Rumo a uma redistribuição desobediente de gênero e anticolonial da violência. São Paulo: Fundação Bienal de São Paulo, 2016.

RUFINO. Luis. Encantamento: sobre política de vida. Rio de Janeiro. MV editora, 2020

SUÊNIA ANE. Cantor, compositor e 'artivista', homem trans usa arte como refúgio para conquistar espaço. G1 Paraíba, 2020. Disponível em: https://g1.globo.com/pb/paraiba/noticia/2020/01/31/cantor-compositor-e-artivista-homem-trans-usa-arte-como-refugio-para-conquistar-espaco.ghtml Acessado em 21 de 2021 


\section{COM O QUE SONHA O LULA? KRENAK SONHA COM LIVES}

what does Lula dream about? Krenak dreams about lives

¿con qué sueña Lula? Krenak sueña con lives

> Julia Raiz [Universidade Federal do Paraná, Brasil]*

Maré [Artista independente, Brasil]* *

RAIZ, Julia; MARÉ

Com o que sonha o Lula? Krenak sonha com lives. Revista Poiésis, Niterói, v. 23, n. 39 , p. 73-93, jan./jun. 2022.

[DOI: https://doi. org/10.22409/poiesis.v23i39.52946]

Este documento é distribuído nos termos da licença Creative Commons Atribuição Não Comercial 4.0 Internacional (CCBY-NC) (c) 2022 Julia Raiz, Maré.

\section{RESUMO COM O QUE SONHA O LULA? KRENAK SONHA COM LIVES não é só um texto, é uma} sondagem no escuro. A bandeira nos chamou para uma DR. Sonhamos com e sem ela. Depois recolhemos o que deu das não-imagens, não-significações, não-identidades. Tudo no sonho muda como na natureza, todas as formas caminham para a indefinição. COM O QUE SONHA O LULA? KRENAK SONHA COM LIVES é registro da indefinição dos sonhos. Trabalhamos a partir do princípio de Estigmergia. Na estigmergia não existe planejamento prévio, mas um encadeamento de ações que puxam outras ações. A gente vai lá e faz para dar início a uma Ação Oportunista [Ritual Poético], dá um passo atrás pra ver o que aconteceu e depois faz de novo, dando início a outra Ação. Aqui sonhamos como gente e trabalhamos como formigas. A bandeira não disse nada porque a bandeira não existe.

PALAVRAS-CHAVE sonhos; ação oportunista; estigmergia; pensamento decolonial.

\footnotetext{
* Julia Raiz é doutoranda em estudos literários na UFPR. E-mail: julia.raiz@gmail.com. Orcid: https:/ / orcid.org/0000-0003-4966-9568

* * Maré é artista, nordestina y gogoia. E-mail: naomorratriste@gmail.com, @tornadaMare
} 


\section{ABSTRACT WHAT DOES LULA DREAMS ABOUT? KRENAK DREAMS ABOUT LIVES STREAMS is not}

just a text, is probing in the dark. The flag called us to DTR. We dream with and without her. Then we gather what has become non-images, non-meanings, non-identities. Everything in dream changes as in nature, all forms move towards indefiniteness. WHAT DOES LULA DREAMS ABOUT? KRENAK DREAMS ABOUT LIVES STREAMS is a record of the indefiniteness of dreams. We work from the principle of stigmergia. In stigmergy there is no prior planning, but a chain of actions that lead to other actions. We do something to start an Opportunist Action [Poetic Ritual], take a step back to see what happened and then do it again, starting another Action. Here we dream like people and work like ants. The flag didn't say anything because the flag doesn't exist.

KEYWORDS dreams; opportunist action; stigmergia; decolonial thought.

RESUMEN ¿CON QUÉ SUEÑA LULA? KRENAK SUEÑA CON LIVES no es solo un texto, es un sondeo en la oscuridad. La bandera nos llamó por discutir la relación. Soñamos con y sin ella. Luego recopilamos lo que se ha convertido en no-imágenes, no-significados, no-identidades. Todo en el sueño cambia como en la naturaleza, todas las formas se mueven hacia la indefinición. ¿¿CON QUÉ SUEÑA LULA? KRENAK SUEÑA CON LIVES es un registro de la indefinición de los sueños. Trabajamos desde el principio de Estigmergia. En la estigmergia no existe una planificación previa, sino una cadena de acciones que desembocan en otras acciones. Vamos allá y lo hacemos para iniciar una Acción Oportunista [Ritual Poético], damos un paso atrás para ver qué pasó y luego lo volvemos a hacer, comenzando otra Acción. Aquí soñamos como personas y trabajamos como hormigas. La bandera no dijo nada porque la bandera no existe. PALABRAS CLAVE sueños; acción oportunista; estigmergia; pensamento decolonial. 
Tenho mania de ver muito. Vi muitas entrevistas e lives de Krenak falando, sua fala de árvore e jabuti sempre me trazem as garras da onça a presas da onça, me sentia sempre silvestre e animal ao término das falas, e em uma dessas lives, ouvir: Krenak só faz live se sonhar que a fez, ele recebe o convite e se sonhar ele confirma, se não sonhar ele nega, pensei em quanto poderia entrelaçar minha vida com o sonho, me lembro de sonhar com os corredores da escola que só fui estudar depois de 5 anos do sonho ter acontecido. Me lembro de sonhar que dava o cu para alguém em um quarto que nunca tinha vida, depois de 7 dias dei para uma travesti nesse mesmo quarto, enquanto o pau dela estava dentro de mim, pensava no sonho e me sentia no passado, em um futuro já passado, ela me comia como quem devora uma manga, sem medo de fiapos no dentes. Krenak passando jenipapo na cara esperando não agredir um protocolo que o agride, quanta glória existe no caçador que saúda sua presa, desenha a caça no útero da terra, para que nela existam mais daquela que foi caçada, que virou comida. Quero muito ser comida e desenhada no útero da terra, nas paredes do meu útero está desenhado enormes cavalas, gigantescas éguas e búfalas e bixas da cara preta, e travas pretas, e vários transmasculinos, seres de bucetas que não se rivalizam e glorificam um novo mundo, um ritual está pintado na parede do meu útero.

\footnotetext{
<< esse trabalho é sobre isso, sabe, não só no contexto amplo, mas do sistema prisional também, quando a Dilma foi...sofreu impeachment eu comecei a anotar alguns sonhos que comecei a ter com esses símbolos do Estado brasileiro e...esse é o meu interesse, investigar como todas essas questões impactam o nosso inconsciente para além do discurso racional, para além do nosso dia-a-dia, para além do que a gente entende como nos impacta, sabe. Porque sonhos também tem essa ambiguidade né, coisas que passam pela sua cabeça,
} 
quando você está dormindo você tá processando e ao mesmo tempo é isso dos sonhos serem mais do que metas...enfim...tem essa ambiguidade. E eu acho que é uma maneira de...eu não digo humanizar as pessoas, mas é uma maneira de mostrar que todo mundo tem a sua profundidade, assim. Eu acho que sonho pra mim, o inconsciente pra mim é isso. São camadas mais profundas de relação, então a partir do momento que eu penso que todo mundo sonha ou que todo mundo já sonhou ou que todo mundo tem essas imagens muito loucas passando pela cabeça eu sei que todo mundo, pensei especificamente na minha bisa, especificamente a vó Paulina, que já faleceu há uns anos. Você olhava a vida dela, nossa, que vida pacatinha, assim sempre andando devagar, falando muito pouquinho, mas ela sonhava, ela também tinha essa profundidade de inconsciente... >>

Bom dia presidente Lula,

Boa tarde presidente Lula, Boa noite presidente Lula.

Os sonhos do Lula apareceram na minha mente enquanto eu ouvia as pessoas fazendo comida na frente da PF e gritando

Bom dia presidente Lula,

Boa tarde presidente Lula, Boa noite presidente Lula.

O que sonha o Lula?

Krenak sonha com Lives.

Com o que sonha o Lula?

Movimentos para se tornar uma presidenta

Dormi com a cara pintada de verde amarelo se cobrir com a bandeira do brasil deitar com a cabeça no cruzeiro do sul rasgar a bandeira, vestir os farrapos. dormi. 
Bom dia presidente Lula,

Boa tarde presidente Lula, Boa noite presidente Lula.

é muito bom pensar que jesus e barrabás são a mesma pessoa

é muito bom acessar barrabás e jesus de si

abel e caim

eva y adão

y a maçã y a cobra.

Com o que sonha o Lula? Krenak não sonhou com Live.

Os sonhos do Lula apareceram na minha mente enquanto eu ouvia as pessoas fazendo comida na frente da PF e gritando

Bom dia presidente Lula,

Boa tarde presidente Lula, Boa noite presidente Lula.

Com o que sonha o Lula?

Não quero pensar o brasil como país do futuro. não quero mais nenhum futuro. quero me desatar do passado. não quero recompensas pelas minhas boas ações nem castigo pelas minhas ruins. quero parar a frutificação horrivel da causa e consequência.

Isso aqui não é só um trabalho, é uma sondagem no escuro. Sonhando em mudar. Mudando pra sonhar. Depois recolhendo o que dá das não-imagens, não-significações, não-identidades. Tudo no sonho muda como na natureza,

todas as formas caminham para a indefinição. 
Percepção -> Ação pela Cognição Situada

Rituais Poéticos / Ações Oportunistas

As formigas não precisam de linguagem, não precisam de mapas ou memórias. Não existe para as formigas ensinamentos, nem transmissão.

Só cheiro.

Hormônio liberado quando acham comida. Quanto mais comida, mais forte o hormônio. E as outras seguem e fortalecem o rastro como seus cheiros. E assim

Todo mundo come

Sonhar para fazer todo mundo comer, que sonho bom!

AÇÃO OPORTUNISTA

COMPRAR UMA BANDEIRA DO BRASIL - DORMIR COMELADEBAIXO DO COLCHÃO-ESCREVER

\author{
< Comprei uma bandeira do Brasil \\ na Casa China e fiquei com vergonha \\ da atendente. Dormi com a bandeira \\ embaixo do colchão. A bandeira não \\ me disse nada.
}

Constatei por mim mesma que a bandeira do Brasil no interior de São

Paulo é só no templo dos coxas, o

templo de plástico. Havana. A liberdade

\begin{abstract}
que por aqui higienizou o bairro de
Puta acabando com o comércio de muitas, chegou até rolar agressão em uma das trabalhadoras do bairro por esses caras fardados e fadados a uma carreira curta, com cal e sal. Elá onde a Dama Liberdade faz ponto na esquina, é que encontrei a bandeira >>
\end{abstract}

O que eu estava pensando?

A bandeira é um pedaço de Pano. E as estrelas estão tortas.

O pedaço de Pano foi transformado num símbolo, contra a sua vontade. 
O Pano está confuso e cansado. O Pano viajou até aqui pra ser bandeira debaixo da minha cama. 0 tecido foi violado.

Não presenteamos um bebê recém nascido com uma bandeira, foi o que o Pano me fez pensar. O tecido é áspero. O que queria ter sido o Pano? A bandeira não disse nada porque ela não existe.

Com o Pano debaixo do colchão, sonhei com um objeto cortante saindo do ponto em que me cortaram durante a cirurgia.

O objeto metálico depois virava um aparelho de depilação, que virava depois um copo plástico com tampa e canudo. As médicas do SUS tinham esquecido o copo dentro de mim enquanto conversavam sobre a nova gravidez da Kylie Jenner. Elas disseram: queríamos ter nascido da barriga da Kylie. 0 médico assistente respondeu: Ainda dá tempo se você se matar agora, para reencarnar no bebê.

Essas foram as últimas palavras que eu ouvi antes de apagar com a anestesia.

Pano sem País, você tem alguma coisa a ver com esse sonho de corte?
AÇÃO OPORTUNISTA

POR A BANDEIRA NO SOL - SENTIR O CALOR DO PANO NO ROSTO - ASSOAR O NARIZ NA BANDEIRA

Tiro o celular da tomada antes de acabar toda a carga Já pensei em terminar com vc 4 vezes só hoje Não sei o que me impede de falar.

Sempre transformei silêncio em palavra

Escrever cartas de ódio

Escrever cartas de amor

Escrevo pois vc já dorme e eu não vim aqui para dormir sozinha.

Estou adiando o nosso fim por que eu não sei

Sou criativa

Imagino mil fins

1

- vamos terminar

Acredito que preciso fazer isso por nós duas

Você não teria coragem, Brasil.

Você prefere fixar os olhos na paisagem

no azul do céu, no verde das matas 
e no ouro.

E esconder de mim aquilo que na verdade é cemitério, terra saqueada,

sangue que sai da seringueira, sangue de Chico Mendes.

Não quero entrar na sua mente mas

Você mesma que me falou

"Ordem e Progresso"

como progredir sem tapar a hemorragia das balas.

Posso apenas te regar e deixar ir

2

-vamos terminar

Ao teu lado eu me sinto sozinha

Me agrada apenas seu braço forte em minha

cintura quando dormimos

em lugar que não é meu, em casas que não são minhas

em berços esplêndidos.

Gosto mais da gente dormindo

A vida nos quer acordada

RAIZ, Julia; MARÉ. Com o que sonha o Lula? Krenak sonha com lives.
Hoje não sei se irei dormir

Despertei com você e agora quero sair

Não sei nem porque vim. porque te chamar de Brasil

território que só em brasa queima.

que a árvore vermelha já não existe mais

Investigo deduzo e frito

Você mesmo já fritou e eu fiquei engordurada

Tomo uma Coca-Cola gelada para desentupir

Amor ruim

Pia entupida

Privada

Privatização

e Dívida Histórica.

Coca-Cola gelada cura até ressaca

Não pretendo beber para te esquecer

Quero é lembrar mais de mim

Ainda bem que lembrei

de ver a noite como um oceano

uma luta que vem para arrebatar

um olho que chora, apenas um olho que lacrimeja

e as gatinhas mortas 
A gatinha pariu

Transcreveu

Acreditou

Parece que me dói te deixar

Como se fosse desistir de nós

E se for? E se eu for?

Eu vou. Arranjo outros.

Ficcionar um outro país onde as vidas não caem

onde os corpos voam

onde a fera que se aproxima vem para comer o Jesuíta.

Desatou o nó da minha garganta

Desato o nó da minha garganta

Passo mel

Passo a entender o lugar de falha

isso mesmo um lugar de falha

Construo mantas de cura

Desato o nó da minha garganta
Como uma santa

E desatado o nois

3 - Vamos terminar!

Enrosco

Embromo

Embolada e amarração

Desfaço o nó coxo do meu coração

Desato o nó coxo de minha garganta

Não tenho medo das reações

Das suas, das minhas.

Eu não preciso temer

Conhecer e necessário

Navegar é preciso

Travecar y edificar a vida

Firmar seus alicerce em outra coisa

que não colunas vertebrais humanas.

Agraciar as rédeas da vida

Com comando de mares

Mares e sol

Maré e Mares 
$<<$ Entrei. Procurei. Imagine em qual departamento se coloca a bandeira do Brasil, o espanto. É o templo do horror! A bandeira do Brasil fica na moda masculina, do lado de camisas com frases patéticas e idiotas, em verde e amarelo. Efui ao caixa, pagar19,90 em um pedaço de pano que tem o peso de mais de 550 anos de história, milhares de hectares, ouro de garimpo e toneladas de corpos $>>$

\section{AÇÃO OPORTUNISTA}

SONHO COM R. - COM O QUE SONHAVA R. QUANDO ESTAVA LÁ? - QUE TRABALHO BONITO, SABE, VOCÊ ME EXPLICANDO NESSE ÁUDIO ACHO QUE EU ENTENDIMELHOR, FAÇA COMO VOCÊ QUISER TRANSCRIÇÃODE ÁUDIO

Então, eu sonhava, sonhava bastante os 9 meses que eu tava lá. Nos primeiros dias eu não conseguia dormir, eu tava assustada com o quanto tudo era feio e sujo. E ai nos primeiros dias eu dormi, não lembro assim, acho que demorou muito pra eu dormir, acho que eu fui dormir no sexto ou sétimo dia de cansada assim.
Eu tinha muito pesadelo. Eu via muita mulher sem dente, eu tinha muito medo de perder meus dentes então eu sonhava comigo banguela. E assim várias vezes eu acordava no meio da noite e contava os dentes, passava a língua pra saber se eles estão lá. E depois foi normalizando os meus sonhos assim, é, eu sonhava muito, eu fazia mentalização antes de dormir assim pra conseguir relaxar e pra deixar aquele lugar menos ruim, sabe. Ai eu sonhava com o que eu ia fazer quando eu saísse, que ia acabar, tinha sonhos sabe com jardins, com... eu tentava ser positiva assim.

Outra coisa, a gente revezava quando tava no barracão 2 os dias de quem ia dormir deitada, quem ia dormir em pé porque a cela era super lotada sabe. A gente dividia em 10, cabiam 6. Mas foi um período bem curto, eram uns 2 meses. E quando eu dormia em pé eu sonhava muito que eu tava num barco, que eu tava num ônibus, eu sentia um movimento acho que de...de desequilibrando, de dormir, eu tinha esse tipo de sonho. eu sonhava muito com a minha família, eu tinha muito pesadelo também de sair e as pessoas que eu...que meus avós tivessem morrido, que eu não fosse ver nunca mais. Eu também tinha pesadelo com as pessoas não falando comigo, mas eu tinha sonhos também que as pessoas iam estar me esperando e que ia dar tudo certo. 
Ah, eu tinha uns sonhos bem loucos assim, isso que eu nem passei muito tempo né, foram 9 meses. Mas eu imaginava que quando eu ia sair o mundo ia estar meio os Jetsons, já ia ter carro voador, umas coisas assim.

Quando iam fazer inspeção com cachorro, eu sonhava com cachorro à noite, sabe. E não era um sonho negativo assim, era meio que a repetição da cena, sabe. Ah, eu tinha muito pesadelo no começo assim...

Minha mãe me ligou, desculpa. Então, eu me impressionava muito com a sujeira, eu tinha muito pesadelo assim e sonhava assim com a sujeira de lá de uma maneira mais exagerada. Até hoje eu tenho pesadelo, com a sujeira principalmente. Eu sinto que estou num lugar sujo, que não consigo sair. Que tem barata e rato, que aquele cheiro de comida recozida às vezes vem. Hoje é o tipo de pesadelo que eu tenho e eu tenho muito pesadelo de assim, sei lá, nunca mais passar essa história, sabe. Sempre ser a menina que passou por isso. Sempre ser a mulher que passou por isso. Nunca evoluir na vida por causa disso, assim. Mas eu acho que esse é um sonho bem consciente porque acordada eu também tenho.

E hoje quando eu penso nas mulheres que dividiram cela, assim, que eu convivi, às vezes eu sonho com elas. Algumas... a maioria eu perdi contato e eu sonho com o que elas me contavam, se elas realizaram ou não, enfim...eu sei que eu estou falando de depois, acho que vocês queriam enquanto eu tava lá dentro.

E eu lembrei que eu esqueci de dizer que quando tinha rebelião na prisão dos macho e que dava pra ouvir porque era na mesma quadra eu tinha muito pesadelo com isso. Eu tinha muito medo que virasse a nossa Piraquara ali, sabe. Era uma coisa que me assustava, era uma coisa que me vinha recorrente assim.

\section{AÇÃO OPORTUNISTA}

SENTAR NO CHÃO NO ESCURO - COLOCAR A BANDEIRA EM CIMA DA CABEÇA COBRINDO OS OLHOS - PSICOGRAFAR MENSAGEM DA BANDEIRA [O PANO] - SONHAR - ESCREVER O SONHO

MUITO SANGUE.

PEDAÇOS DE PESSOAS CRESCENDO

EM ÁRVORE

EXIBIR PESSOAS QUE

FORAM MORTAS 
O AMARELO ESCORRE

O VERDE ESCORRE

AS ESTRELAS GRUDAM NA

SUA CABEÇA

O QUE VOCÊ QUER SABER?

ESQUECE O QUE VOCÊ ACHA

QUE SABE SOBRE ESSA

TERRA

VOCÊS NÃO SABEM DE NADA

QUEM FAZ ESSA TERRA SÃO FUNGOS E BACTÉRIAS QUE

DECOMPÕEM OS MORTOS

NÃO EXISTEM MORTOS

EXISTE COMIDA

LÁ EMBAIXO TODO MUNDO COME.

SEUS OLHOS ESTÃO PESADOS

VOCÊ TEM UM PAÍS

NA CABEÇA E ELE NÃO

É O QUE VOCÊ PENSA

SONHE FUNGOS E BACTÉRIAS
PEÇA PARA ELAS A INTELIGÊNCIA

QUE VOCÊ NÃO TEM.

SEUS OLHOS ESTÃO ARDENDO

SÃO AS ESTRELAS

FERINDO SEUS OLHOS

A PALAVRA ORDEM A PALAVRA

PROGRESSO SÃO SÓ UNS

RISCOS

VOCÊS TÊM MEDO DE

TUDO

ATÉ DOS RISCOS

SE O VERDE PEGAR FOGO

SUA CABEÇA VAI PEGAR

$\mathrm{FOGO}$

SE O AMARELO ESCORRER

VAI AGARRAR NA SUA CABEÇA

E O AZUL? O AZUL SAI

ROLANDO E ROLANDO PRA SEMPRE 
COM O BRANCO VOCÊ MESMA FAZ UMA FAIXA

PRA TAPAR SUA BOCA

NÃO PENSE MAIS

OLHA PRA MIM! VOCÊ TEM

CORAGEM? EU SOU UM

PANO! VOCÊTÁ COM UM

PANO NA CABEÇA. PAÍS, BANDEIRA, ESTRELA

ISSOÉ TUDO

COISA DA SUA CABEÇA!

um corpo meio arroxeado, meio verde, que tentava falar e só água saia da sua boca

eu não senti medo, eu não sentia medo,

eu tentei olhar para ele nos olhos,

mas seus olhos cheios de veias vermelhas,

desviava do meu,

desviava,

não me encarava,

sentia vergonha de si?

Agachou no chão que era terra,

terra barrosa, pegou um pedaço de barro, e pôs na boca.
Não sei se essa bandeira é a perfeita por ser a mais imperfeita formulação de ordem e progresso.



Atravessei uma ponte de tábua por cima de um córrego. Cheguei na boca da floresta, entrei. Lá dentro estão vagando um grupo de pessoas mais velhas, em transe. Encontrei uma mulher e uma criança sentadas no chão e um quati. O quati tem duas grandes presas igual um javali. Na mata tem portas que eu posso entrar e sair. Preciso tomar cuidado por onde entro ou saio para não deixar o quati se sentir acuado porque ele pode me atacar. Do outro lado da ponte de tábua, da onde eu vim, desmontam o Brasil como uma casa antes da mudança.

AÇÃO OPORTUNISTA

SE COBRIR COM A BANDEIRA - ESPERAR ALGO ACONTECER

Ao me cobrir com o manto, percebo quanto é vagabundo seu tecido, viajo por camisa da seleção, coxas de jogadores y Marta. Quantas releituras apropriadas, quanto mais penso que Pelé se tornou 
um símbolo e um local, que sua música abc ABC toda criança tem que ler e escrever, ainda útil, ainda sendo uma nação que analfabeta da língua portuguesa, lingua cobrada pelo regime de Portugal, hoje peleja para recordar a língua de seus povos, de valorizar aqueles que falam o ritmo.

Pretoguês que existe, amém, obrigada por nos afastar daquela enrolação de língua que os portugueses têm.

Fui dormi e não sonhei com nada, repeti a ação no dia seguinte antes de dormi, não tive vontade de escrever nada.

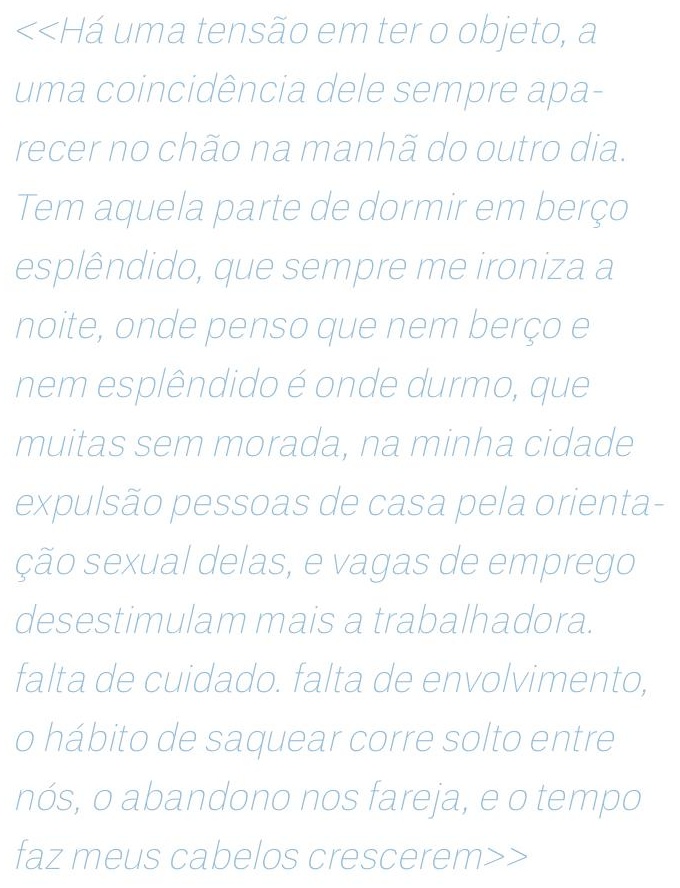

\section{AÇÃO OPORTUNISTA}

COMER BANANA EM CIMA DA BANDEIRA - DEIXAR AS CASCAS CAIREM - AMARRAR A BANDEIRA COMO UMA TROUXA DEROUPAS, AS CASCAS DENTRO - POR A TROUXA EM CIMA DA CABEÇA.

Nosso discurso político é teopolitico.

O mito uma cortina, o mito uma fundação.

A versão do mito

futuro do presente

Necessidade de conhecer o passado.

O presente é constituído pelas forças que estão em ação há pelo menos 500 anos.

Tirar o mito da frente.

\section{Estratégico.}

Fazer um mito com pedaços da realidade.

Pedimos um passado que não conhecemos. Ignorante.

Combater a ignorância no imaginário.

Combater a ignorância que não imagina

Não lutar pela repressão como se estivesse lutando pela liberdade. 
As meninas sempre estiveram certas

Bom Xi bom Xi bom bom bom

Onde o rico cada vez fica mais rico.

E o pobre cada vez fica mais pobre.

Mal sabia as meninas que pobres iriam acreditar que eram ricos.

E o ricos iriam costurar, uma bandeira, um mito, uma fundação que não revelasse a Fundação.

Feita em cima de uma pluralidade, que morta, ainda continua

Continua a pulsar na terra clamando por uma reviravolta.

Uma bandeira delimita um campo

Um território.

um povo pasteurizado não dá conta de um país

A Pluralidade que não dá para ser reduzida.

E se reduzida, o cachimbo bate no touro, que bate na gente

acabou-se o mundo.
AÇÃO OPORTUNISTA

ENCARAR A BANDEIRA - ENCARAR A SI MESMA TAMPAR SUA IMAGEM COM A BANDEIRA - OLHAR EAGUARDAR

A bandeira verde e amarelo. Símbolo, qual é a história dessa bandeira?

O que é?

O verde é a desesperança, o amarelo a tristeza, aí o azul não sei...

os memes contam a história melhor que o mito.

As cores de nossa bandeira são as cores de nossos colonizadores.

A gente se vende

Se venda

Revende

Caminha a supor um lugar final

Lema positivista.

Bandeiras não são só bandeiras

Cores não são só cores.

O projeto de extermínio

E toda América passou por isso e nossos vizinhos contam a história e a gente não conta 
Dizimadas

Dízimos

Dizimadas nas ruas

Dizimadas

Monocultura subjetiva

Só produzindo um modo de ser

violento que danifica o solo

Que mata o que diverge

Transformando florestas em pasto pra boy-escroto pastar

Acumula no coração dos outros a vontade de ser rico e admirado.

"Todo mundo quer comandar e não ser comandado" disse o filósofo se esquecendo das práticas bdsm.

Multidão

Guerra

Essa é a bandeira de nossa guerra

A história do Brasil é eke atrás de eke.
Entender e deixar de jogá-lo

Como fazer isso jogando.

Combate público velado

Cuidado maiores

Cuidado menores

Capacidade de respirar

Reservas de paciência e calma para

continuar lutando

Reservas de ódio e raiva já abarrotados e lotados.

Continuar alegre mesmo que se lute contra o absurdo que está ganhando.

A história conecta coisas

A teia da aranha

Questionar aquilo que se dá como uma certeza.

Realmente um pensamento estreito passa por mim:

O mito subsistindo a realidade? Ou a realidade é uma construção de vários mitos? 
$<<$ Ainda me irrito ao ver que compa-

ram crianças com presidentes. Onde o absurdo se torna possivel, e se possivel fosse uma criança na presidência, tenho pra mim que ela tomaria a realidade a duras goladas, mas jamais arriscaria tudo só pelo seu egoísmo. Crianças são egoístas mas não são tolas. Erês ensinem a eles que criança bixo-gente sábio, que a anciã é sábia,

Ensina para nós Erês, o que já é sabido: Quem planta o terror, a morte colhe, >>

Os mitos podem cristalizar como se fossem uma crença ou a realidade. O mito pode tornar a realidade existente invisível. Os fatos não importam, o que importa é como esses fatos são contados sem comprometimento com a verdade. A bandeira, simplesmente não existe.

Antônio Bandeira assim como eu

também diria

que signo, gesto y ação são tecnologias

A ser humana é muito ardilosa

para se unir foi capaz de muito criativa inventiva

hasteou pedaço de tecido as alturas

Fez mais de uma

criou para se identificar

Pelotão

Reinado

Países

Estados

Identidades

É muito mais

Bandeiras e eu

Se um dia nos beijarmos

Vamos nos decepcionar

Tem vivas que não encaixam

Tem dedos que se assustam com o entrelaçar

e ficam desconfortáveis

Tem desconfortos que são toleráveis

é sempre bom ter para quem dá a azeitona

Uma pessoa da minha família, sai de uma cozinha que não conheço, passa por mim que estou sentada em uma sala que não conheço, é uma casa 
desconhecida, que nas paredes tem retratos, fotos de família tradicional, a pessoa se senta na minha frente, diz frases confusas

"Você irá destruir sua família"

"Você impedirá a continuidade de nossa família"

"você é culpada"

Me encontro parada, querendo falar, mas continuo calada, até que líquido dourado parecendo seiva de árvore começa a sair da minha boca, tento evitar, mas não consigo, abro a boca em ato de entrega, a sala desconhecida começa a se encher de seiva, âmbar por toda a sala, a pessoa continua a falar como se não visse que estou a vomitar, a virar uma fonte de seiva, um gosto doce vai surgindo em minha boca, a seiva já bate em minhas canelas, e da minha boca a seiva não para, continua a cair, pelos cantos da boca quando fecho a boca, e assim que abro sai um jorro forte, meu corpo fica estranho, me sinto bem e ao mesmo tempo como se estivesse queimando em febre. A seiva já toca meus joelhos, me levanto e percebo que não tem mais ninguém naquela sala comigo, começo a andar pela casa que é feita de corredores estreitos, a seiva está por todos os lados, ando com uma certa dificuldade pois a seiva é expeça, chego no quintal; e ao abrir a porta a seiva começa a sair, conquista o quintal com o andar do mel, devagar e espesso, percebo que já não sai da minha boca nada, que conheço aquele quinta, onde uma mangueira grandiosa balança seus galhos mesmo sem vento, ao me aproximar algo sussurra no meu ouvido

"Não tenha medo, o fim é só um outro começo"

\section{AÇÃO OPORTUNISTA}

COM UM TOPE DO BRASIL E CALCINHA, SAMBARE CANTAR MÚSICAS ROMÂNTICAS DA MPB

O verde pertence a casa de Bragança, de Dom Pedro 1

O amarelo vem da casa da Imperatriz Maria Leopoldina.

O Azul, do traço cínico e canalha que força a religião católica para

as indígenas e justifica a escravização dos povos africanos.

Permanece deitado em um berço esplêndido um beber engasgado e roxo, Brasil.

Jardim sem futuro. Sem passado.

Permanece acreditando em um sonho gigante, um sonho gigante. 
As nossas revoluções reduzidas a uma baderna.

Um sintoma

O sintoma de uma cultura nacionali lobotomizada, encarcerada, acostumada a esquecer, desgastada, cansada e forçada a ouvir anedotas.

Dizem que nós não podemos aceitar,

A paz ao preço da violência,

o preço de justificar a violência.

Há uma prática de pacificar,

uma ideia de profano para justificar a violência do

purificar.

Colocar as coisas em ordem

O modo de funcionamento: Destruição.

A República das Espadas, Marechal Deodoro da

Fonseca

e seu grande cuzão que declama o hino.

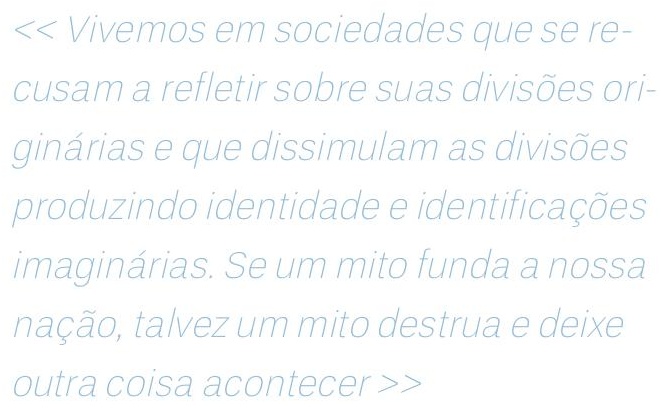

$<$ Vivemos em sociedades que se recusam a refletir sobre suas divisões originarlas e que dissimulam as divisoes produzindo identidade e identificaçoes
$<<$ Não podemos desejar nenhum tipo de retorno,

o fato para além do mito.

Queremos o real sem doer em ninguém>>

: Marilena me encarava com seus olhos de Erê.

Como naturalizar o sonho?

Como pôr em curso um sonho?

Nós somos uma consciência encarnada em corpo que não tem pura consciência.

Não somos pensamento puro. E nem puro somos.

O mundo não é um conjunto de fatos causais e funcionais,

além do mundo existe um mundo como lugar que vivemos com as outras, um mundo cheio de camadas e caminhos, lembranças, afetos.

Um mundo de conflito, esperança e paz. somos seres temporais, no tempo.

Seres especiais. A mata. O campo. O céu. O mundo espacial. Dimensões. Grandes pequenas. O corpo não é um feixe, e nem uma rede. O meu corpo é um sensível que é sensível para si. 
Atopia

Acronia

O Fordismo é quando uma empresa detém e controla a ponta inicial e a ponta final.

Ela é um pequeno planeta.

Ao ouvir Zâmbina falar sobre a confiança que se tinha na confiança do PT no órgão público, no funcionamento do estado, me pareceu óbvio que o ataque seria nesse ponto, fazendo parecer que nem mesmo o PT foi honesto no poder.

Tem mais lógica ir em uma benzedeira do que ler a República de Platão.

\section{AÇÃO OPORTUNISTA}

SE MASTURBAR E GOZAR NA BANDEIRA - TRANSAR EM CIMA DA BANDEIRA

Desafogar mágoa rasteira

Gozar feitiços secretos

Conta as pedras da aruanda. Somar o número em prosperidade

Ser o céu, voar em si, navegar em universos.

Calma

\section{Paciência}

Destreza

Prazer em ser imperfeita

Perfeita forma de prazer

Treinadora

Treinada

Traiçoeira

Mandingueira

Maria Mandinga

Maria Mulambo 
Padilhas e tranca rua.

As travas nas ruas são mais santas que as estátuas

no altar.

Na estigmergia não existe planejamento prévio, mas um encadeamento de ações que puxam outras ações. As formigas nos mostram sem se importar com a gente. A gente vai lá e faz para dar início ao Ritual [Ação Oportunista], dá um passo atrás pra ver o que aconteceu e depois faz de novo.

Aqui sonhamos como gente e trabalhamos como formigas. Partimos do princípio de Estigmergia. 


\section{OS BAOBÁS DO FIM DO MUNDO: TRECHOS LÍRICOS DE UMA ETNOGRAFIA COM RELIGIÕES DE MATRIZ AFRICANA NO SUL DO RIO GRANDE DO SUL}

The Baobás of the end of the world: lyrical excerpts from a african religion ethnography on the south region of Rio Grande do Sul

Los Baobás del fin del mundo: fragmentos líricos de una etnografía de religiones de origen africana en la parte sur de Rio Grande del Sur

$>$ Marília Kosby [Universidade Federal do Rio Grande do Sul, Brasil] ${ }^{*}$ José Darci Barros Gonçalves [Artista independente, Brasil] * *

RESUMO $\bigcirc$ ensaio reúne poemas de Marília Kosby e pinturas de José Darci, que compõem a primeira edição do livro Os Baobás do fim do mundo. Realizada em parceria entre a poeta e o pintor, a obra investiga possibilidades líricas através do encontro etnográfico realizado junto a terreiras na região de Pelotas, sul do Rio Grande do Sul. Os poemas e as imagens descrevem guias, caminhos e vertentes de uma força chamada axé, cuja arte de brotar, se desdobrar e espalhar é um saber gerado, transmitido e atualizado a partir da experiência da diáspora africana.

PALAVRAS-CHAVE poesia; pintura; encontro etnográfico; diáspora africana

ABSTRACT The present essay assembles poems written by Marilia Kosby and paintings from José Darci, which compose the first edition of the book Os Baobás do fim do mundo. Resulting from the partnership between poet and painter, the book investigates poetic possibilities through the ethnographic encounter with terreiras communities in the region of Pelotas, located on the southern region of Rio Grande do Sul state. The poems and images picture guias and pathways of a force called axé, with an ability to root and to spread itself that constitute a shared knowledge, informed by the experience of the African diaspora. KEYWORDS poetry; painting; ethnographic encounter; African diaspora 
KOSBY, Marília

DARCl, Zé. Os

Baobás no fim do

mundo, trechos

líricos de uma etnografia com religiões de matriz africana no sul do Rio Grande do Sul. Revista Poiésis, Niterói, v. 23, n. 39, p. 94-101, jan./jun. 2022.

[DOl: https://doi. org/ $10.22409 /$ poiesis.v23i39.52950]

Este documento é distribuído nos termos da licença Creative Commons Atribuição-Não-

Comercial 4.0 Internacional (CC-BYNC) (C) 2022 Marília Kosby, Zé Darci
RESUMEN El ensayo recoge poemas de Marília Kosby y pinturas de José Darci, que componen la primera edición del libro Os Baobás do fim do mundo. Realizada a través de la colaboración entre poeta y pintor, el trabajo investiga posibilidades poéticas mediante el encuentro etnográfico realizado junto a terreiras en la región de Pelotas, al sur del departamento de Rio Grande do Sul. Los poemas y imágenes describen guías y caminos de una fuerza llamada axé, portadora de una capacidad de germinar y de extenderse que constituye un saber generado y transmitido a través de la experiencia de la diáspora africana. PALABRAS CLAVE poesía; pintura; encuentro etnográfico; diáspora africana

* Marília Kosby, poeta, é Doutora em Antropologia Social (UFRGS).E-mail: floorkosby@gmail.com. Orcid: https://orcid.org/0000-0003-1037-5490

* * José Darci Barros Gonçalves, artista plástico também conhecido como Zé Darci, desde 2009 integra o grupo de artistas Quilombos Urbanos 
A primeira edição do livro Os baobás do fim do mundo teve lançamento em 11 de novembro de 2011, na Bibliotheca Pública Pelotense, esgotando no mesmo ano, depois de realizar exposições de lançamento por diversos municípios do extremo sul do Brasil. Primeiro livro de poesia da poeta e antropóloga Marília Kosby, a obra foi uma parceria com o artista plástico José Darci Barros Gonçalves (Zé Darci), tendo sido publicada pela hoje extinta editora Novitas, de Vera Cruz/RS.

É bem possível ser "Os Baobás do Fim do Mundo" uma obra carente de definições mais precisas às vistas de quem por estas se interessar, é claro. Talvez seja sua publicação a expressão mesma desta busca por um lugar legítimo dentre as construções textuais que se erigem do encontro etnográfico; e que, simultaneamente imprimem neste a pretensão de ser uma experiência em parte apreensível pelos outros, os leitores.

O que se pode dizer a respeito dessa primeira compilação de textos em verso é que o material reunido foi escrito por uma antropóloga, e surgiu durante a fase de conclusão de seu mestrado acadêmico, cujo projeto de pesquisa se tratou da continuidade de um trabalho etnográfico realizado junto a terreiras na região de Pelotas, sul do Rio Grande do Sul.
Os três capítulos em que o livro se divide marcam a passagem de diferentes momentos da experiência etnográfica da autora, trazendo textos que expressam como foi sendo elaborado o conhecimento a respeito do modo de viver junto aos grupos com os quais estudava.

O primeiro capítulo, Etnodelírios, traz versos construídos em sonhos relacionados ao diário de campo, transcritos entre março e julho de 2008 , durante a realização do curso "Jogos, performances e simbolismos - etnografias afro-brasileiras", ministrado pelo professor Marcio Goldman, no Programa de Pós-Graduação em Antropologia Social do Museu Nacional, na Universidade Federal do Rio de Janeiro.

\section{Os textos apresentados no capítulo Do Banzo} foram escritos juntamente com sua dissertação de mestrado, intitulada "Se eu morrer hoje, amanhã eu melhoro: sobre afecção na etnografia dos processos de feitura da pessoa de religião no Batuque, em Pelotas/RS", trabalho defendido em abril de 2009 e orientado pela professora Flávia Rieth, no Programa de Pós-Graduação em Ciências Sociais da Universidade Federal de Pelotas.

Por fim, no capítulo Os Baobás do Fim do Mundo, tem-se os guias, os caminhos, as vertentes, de uma força chamada axé, cuja arte de brotar, se desdo- 
brar e espalhar, é um saber gerado, transmitido e atualizado a partir da experiência de pessoas negras trazidas como escravas da África para as Américas, e que, apesar disto, se constitui não apenas em um patrimônio étnico, mas numa significativa potência de dignidade e vitalidade de imensas minorias americanas. Os textos que compõem este último capítulo foram escritos entre 2009 e 2010, e se relacionam com a experiência de retorno ao campo, o que culminou na atualização de processos religiosos iniciáticos.

Os capítulos são ilustrados com reproduções fotográficas de pinturas do artista plástico Zé Darci (José Darci Barros Gonçalves), integrante do Grupo de Artistas Quilombos Urbanos, da região de Pelotas, e parceiro da autora em outros projetos artísticos.

Visando uma leitura mais compreensivel ao leitor que tem seu primeiro contato literário com o universo filosófico afro-brasileiro, esta obra consta de um glossário alfabeticamente organizado para as palavras sinalizadas em itálico.

Enfim, antes e além de tudo, este livro é uma forma de retorno ao pessoal "de religião", que encarregou sua autora de "levar a beleza de suas religiões para fora dos muros das terreiras". Beleza das "coisas que nos comovem, na medida em que, traduções míticas de nossa estrutura interior, lançam luz sobre nós mesmos ao mesmo tempo em que resolvem nossas contradições num acorde único".'

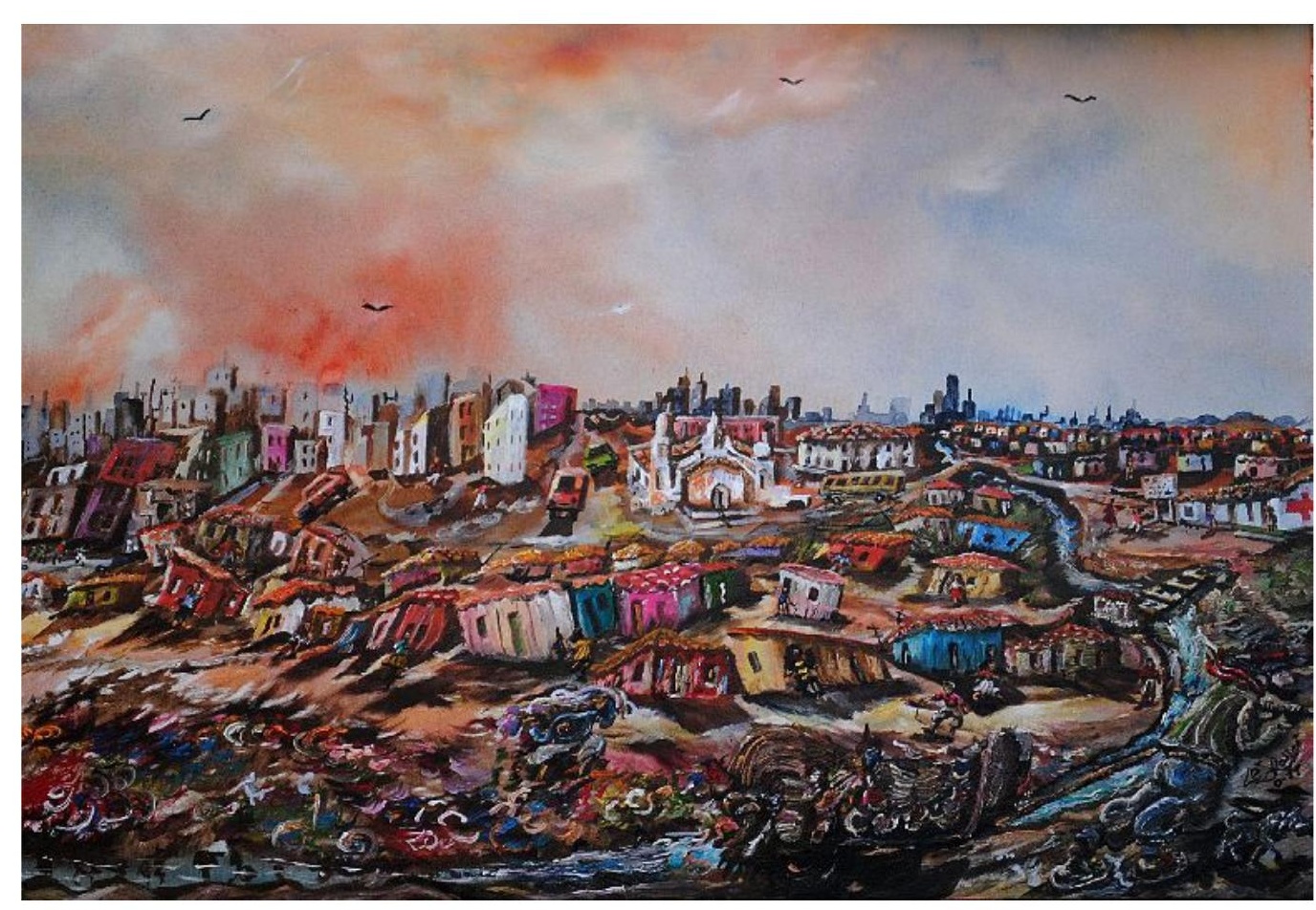

João Saudade, acrílica s/ tela. 
O OUTRO

Eu sou como você

porque tenho medo de você Medo

de servocê

e nunca mais encontrá-lo noutro lugar

fora daqui

Te perco tanto mais te sou

\section{ANTROPOLOGIAS}

Eu tenho as tuas palavras e uma dose quase nula de certeza

para ser capaz

de evitar as minhas



Pai Silvério, acrílica s/ tela. 
SACRIFÍCIO

Sacrificai o vosso corpo

em nome de um espaço que aguente vossos tempos de consciência e sanidade

Explicai vossos desejos

nos desenhos sujos de vossa pele intacta

Atravessai as horas, os metros cúbicos,

os anos bissextos

emaranhados em vossas palavras

sempre tão pequenas

compartimentos transbordantes

de uma vida que não sabe e nem conhece nada de irreal

Comparai o valor de vosso sangue

e percebei que o mundo que vos deram vossos planos

não abarca sonhos nem lampejos

Ele não contempla beleza e movimento

Orai ao vento

rogai ao vento

entregai ao vento

Ele que organize as contas

da desgraça que é ser

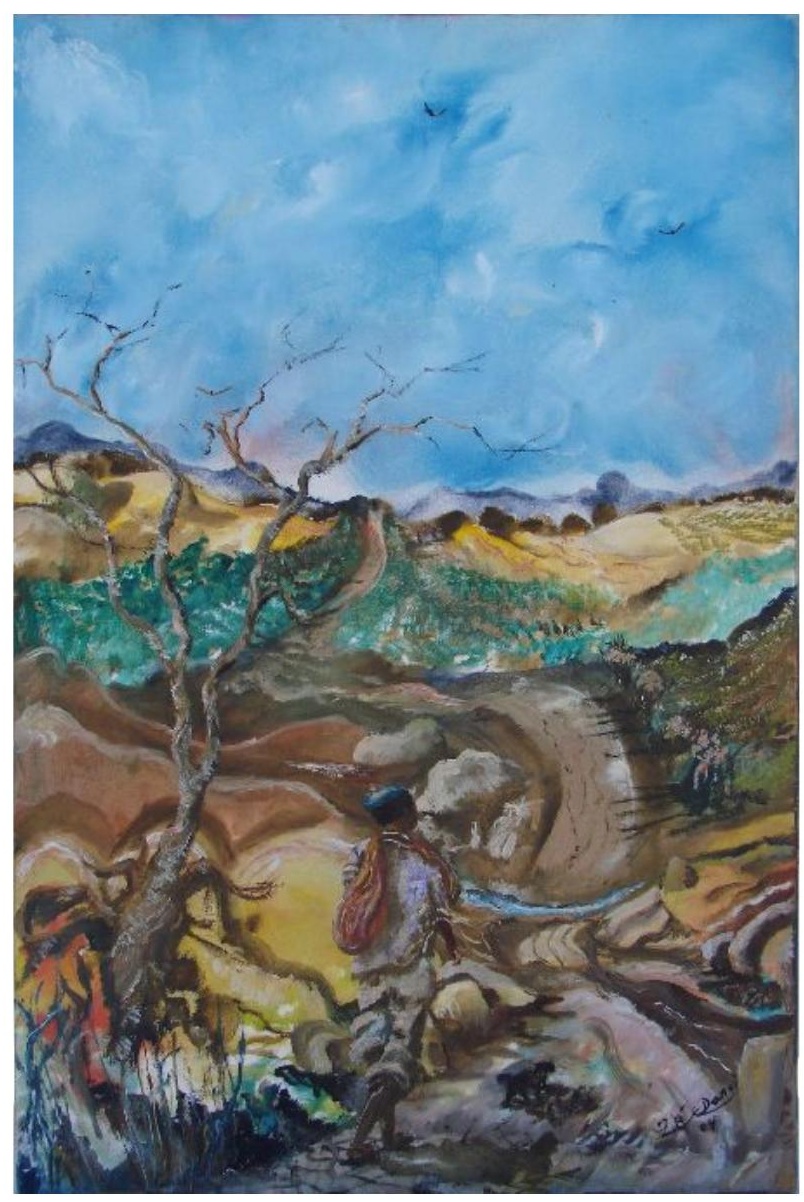

ao mesmo tempo

chão e bolha

céu e âncora 
OS BAOBÁS DO FIM DO MUNDO

Zimbábue

com "z", de beiço

O meu pai tem um pé no Xingu e outro no fogo A minha mãe, a boca de quem come flor

e gosta

Meus irmãos são só saudade

Os avós, um bicho grande

sangram entre o céu e eu

Enquanto os santos banqueteiam

agarradas às costas do mundo

as figueiras se eternizam

A SAIA DE MAMÃE

É tão linda a saia de mamãe

na beirinha da praia

É tão bonito ver o mar

todinho aos seus pés

Que ela lavre meu peito em segredos

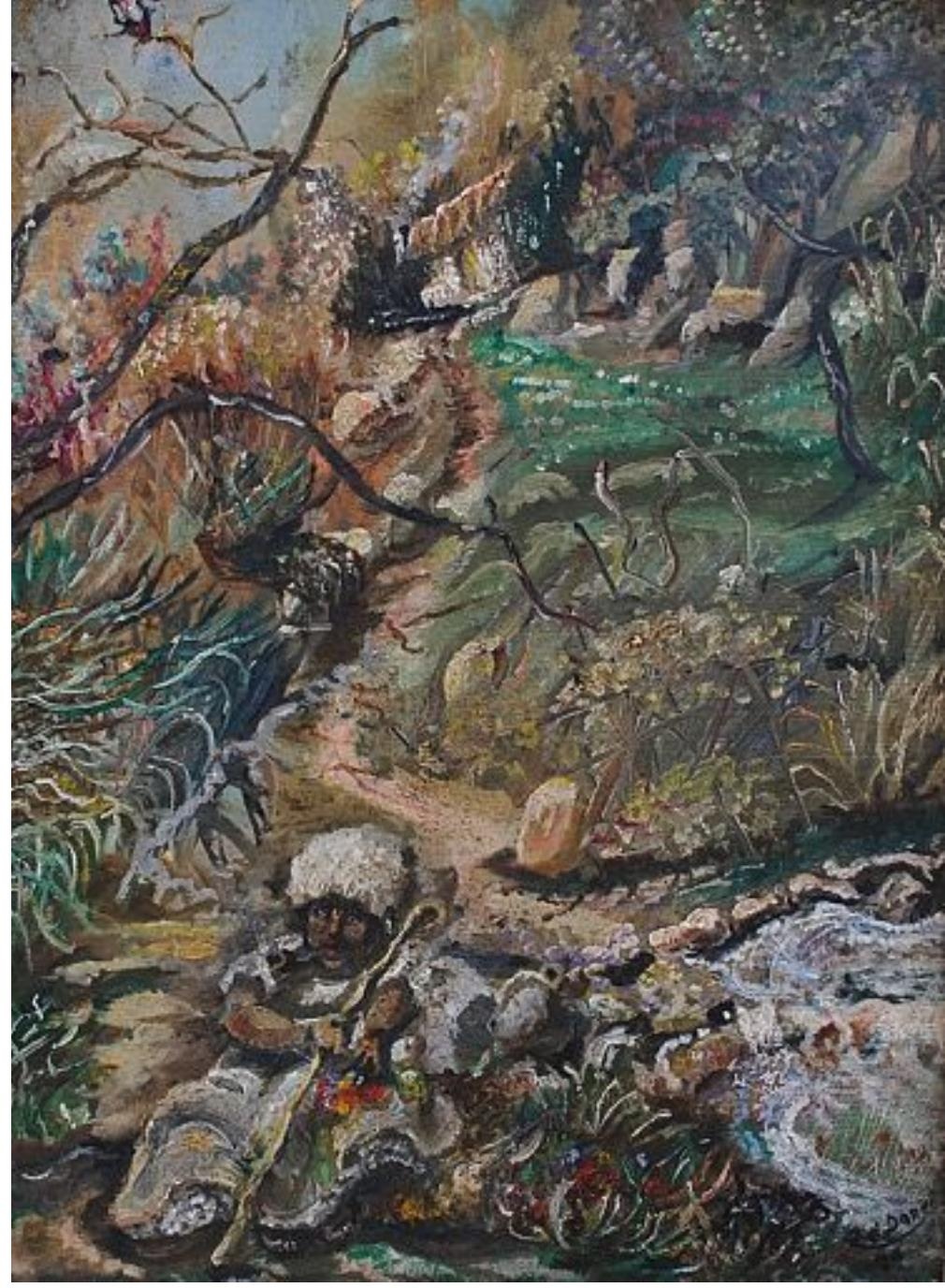

Vó preta, óleo s/ tela.

Que desfaça o feito em claridades

no meio dessa noite cega

NOTAS

é tudo o que eu posso pedir

Mamãe verte o mar com os olhos

ela embala as ondas no colo

1 LEIRIS, Michel. Espelho da tauromaquia. São Paulo: Cosac \& Naify, 2001. 


\section{SÉRIE MAPAS}

Cartography Series

Serie Mapas

Talles Lopes de Oliveira [Universidade Estadual de Goiás, Brasil]*

LOPES, Talles. Série Mapas. Revista Poiésis, Niterói, v. 23, n. 39, p. 102-114, jan./jun. 2022. [DOI: https:// doi.org/10.22409/ poiesis.v23i39.52951]

Este documento é distribuído nos termos da licença Creative Commons Atribuição-NãoComercial 4.0 Internacional (CC-BY-NC) (C) 2022 Talles Lopes
Assim como em Terra Brasilis (1519), grande parte dos mapas coloniais do Brasil estão marcados por um evidente contraste entre um Leste colonizado e nomeado com topônimos europeus, com um Oeste desconhecido, representado como um grande vazio continental ou uma região idílica cheia de riquezas e criaturas mitológicas. Esse tipo de leitura do território está ligada ao imaginário colonial das primeiras invasões bandeirantes no Brasil central, que compreendiam o Oeste como um espaço exótico e selvagem passível de ser colonizado.

A construção da narrativa colonial sobre o Oeste do Brasil como um lugar a ser explorado foi resgatada pelo estado brasileiro no século XX, tornando-se enredo do processo de modernização e unificação territorial que visava ocupar o interior do país, resultando na construção de cidades modernas como Goiânia e Brasília. Não por acaso, as propagandas da Marcha para o Oeste (1938), programa de expansão agrícola do governo Vargas, e os mapas do Atlas do Brasil (1959) publicado pelo IBGE em função da construção de Brasília, parecem atualizar os contrastes entre Leste e Oeste presente nos mapas coloniais.

Partindo dessas observações, através da produção de um conjunto de mapas venho me dedicando a investigar a contraditória filiação das narrativas do Brasil moderno nas representações cartográficas coloniais, procurando discutir como o aparato técnico-científico e supostamente neutro da cartografia moderna atualizou narrativas mitológicas de dominação do Brasil Central.

*Talles Lopes de Oliveira é artista visual, arquiteto e urbanista graduado pela Universidade Estadual de Goiás. E-mail: talleslopes.go@gmail.com 




A Marcha. 2018. Acrílica e nanquim sobre tecido. $160 \times 83 \mathrm{~cm}$. 
Condenações. 2016. Tríptico. Acrílica, aquarela e nanquim sobre papel.

$101 \times 72 \mathrm{~cm}$ cada.

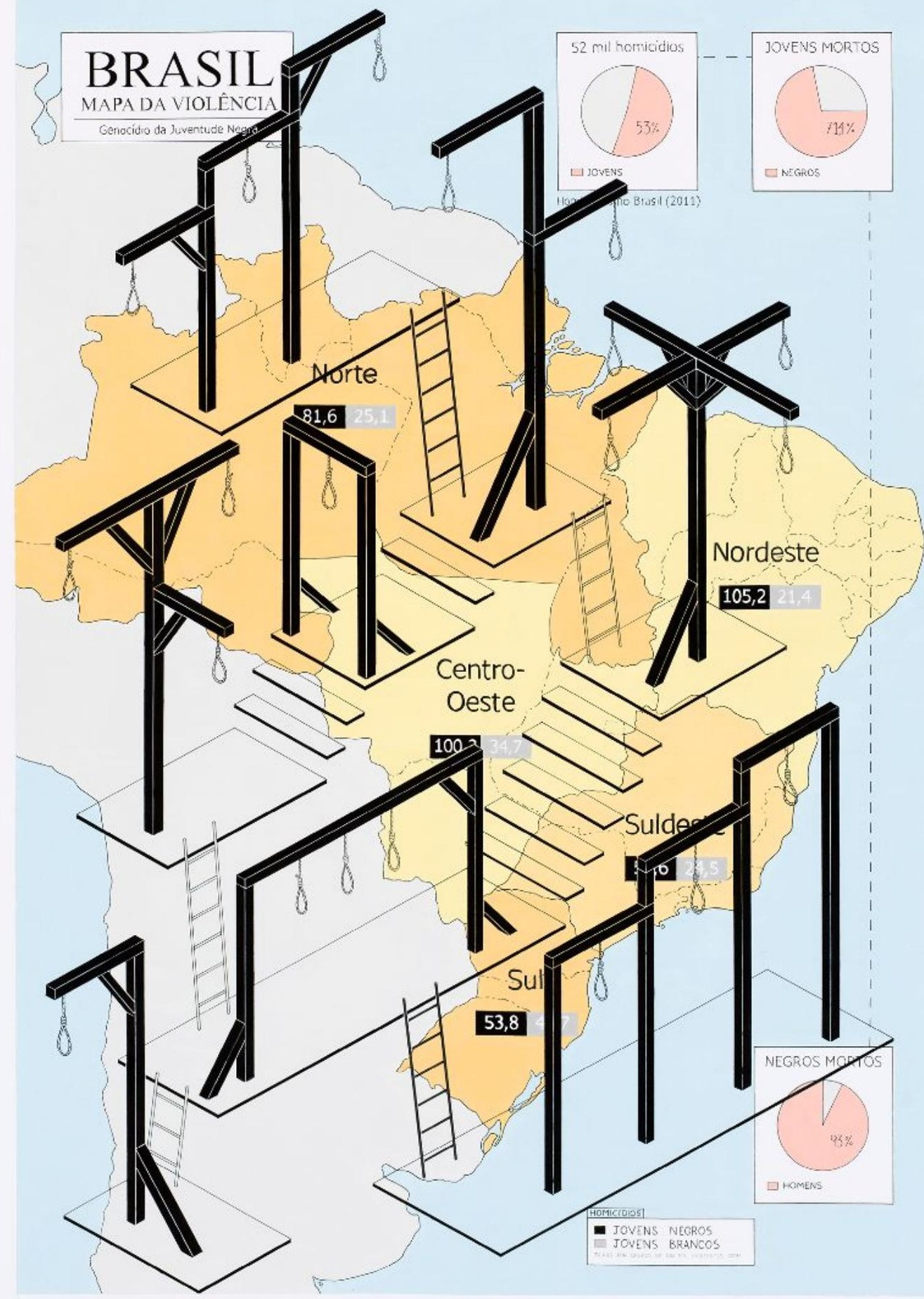




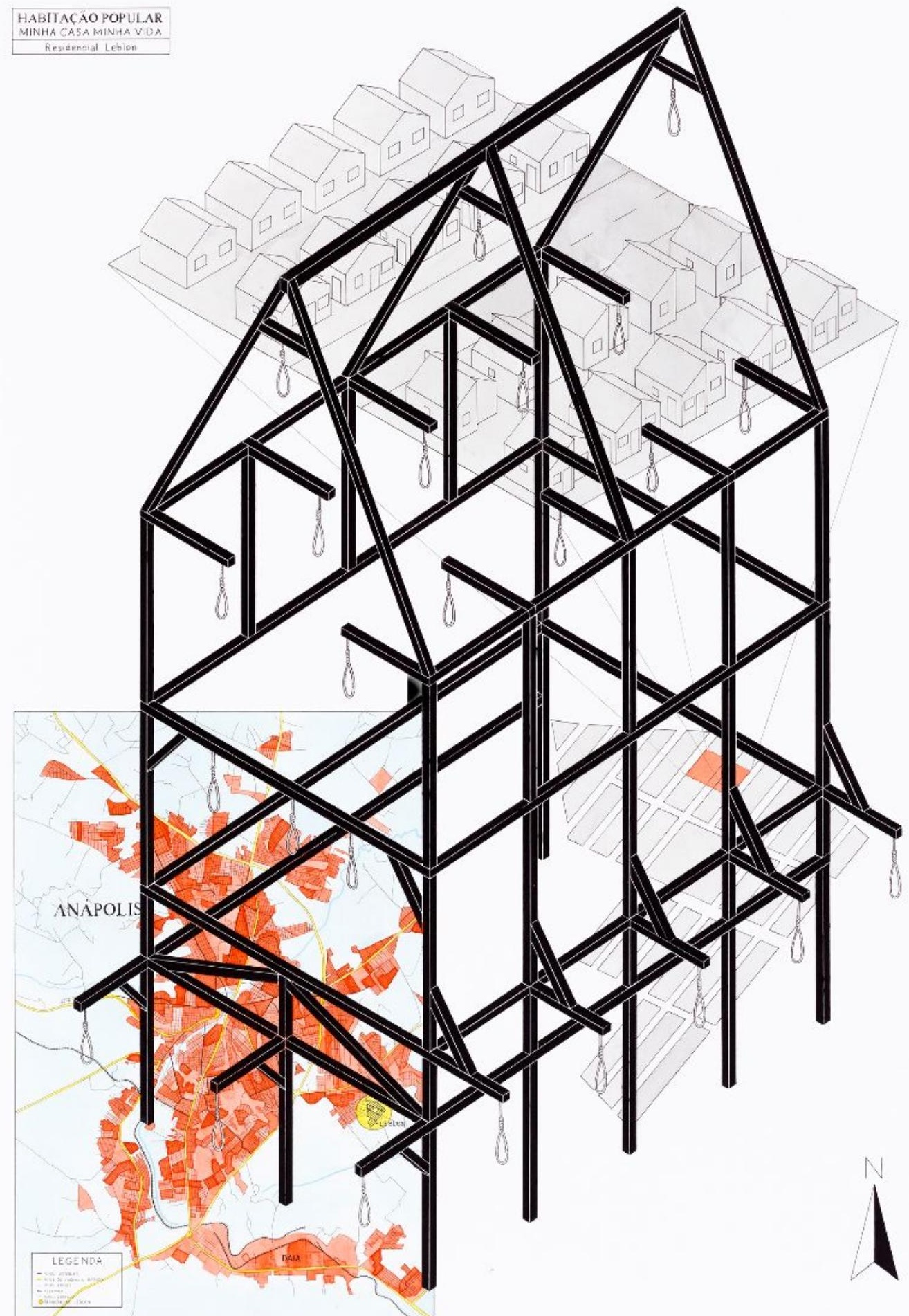

Condenações. 2016. Tríptico. Acrílica, aquarela e nanquim sobre papel.

$101 \times 72 \mathrm{~cm}$ cada. 


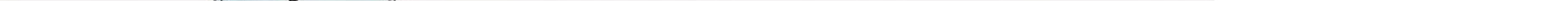

Duo. 2016. Nanquim e aquarela sobre papel. $101 \times 72 \mathrm{~cm}$. 


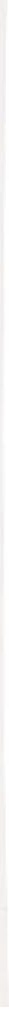

Mapa Estriado. 2020. Acrilica e nanquim sobre tecido. $160 \times 83 \mathrm{~cm}$. 


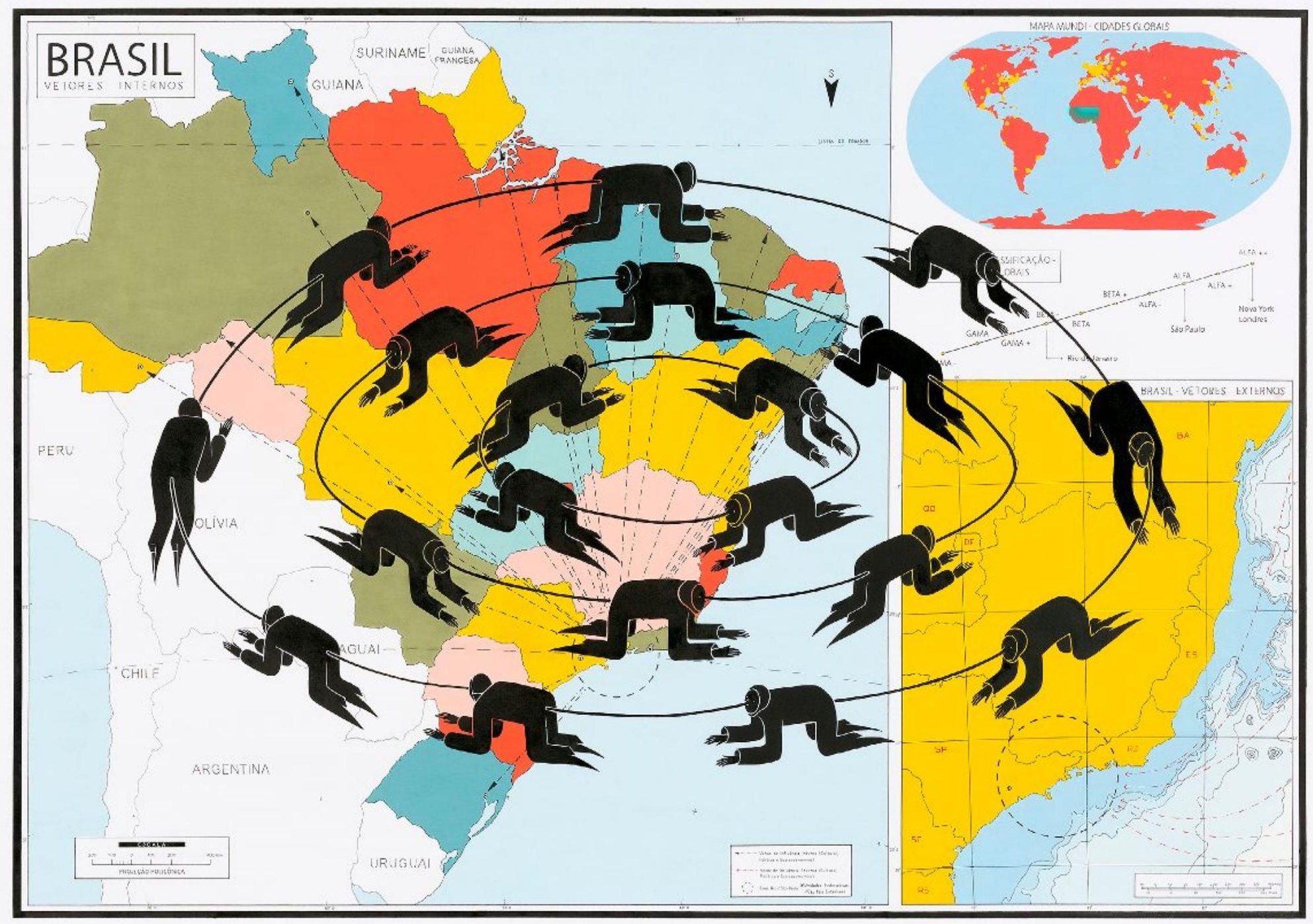

Modelos e circuitos. 2017. Nanquim, guache e acrílica sobre papel. $72 \times 101 \mathrm{~cm}$. 


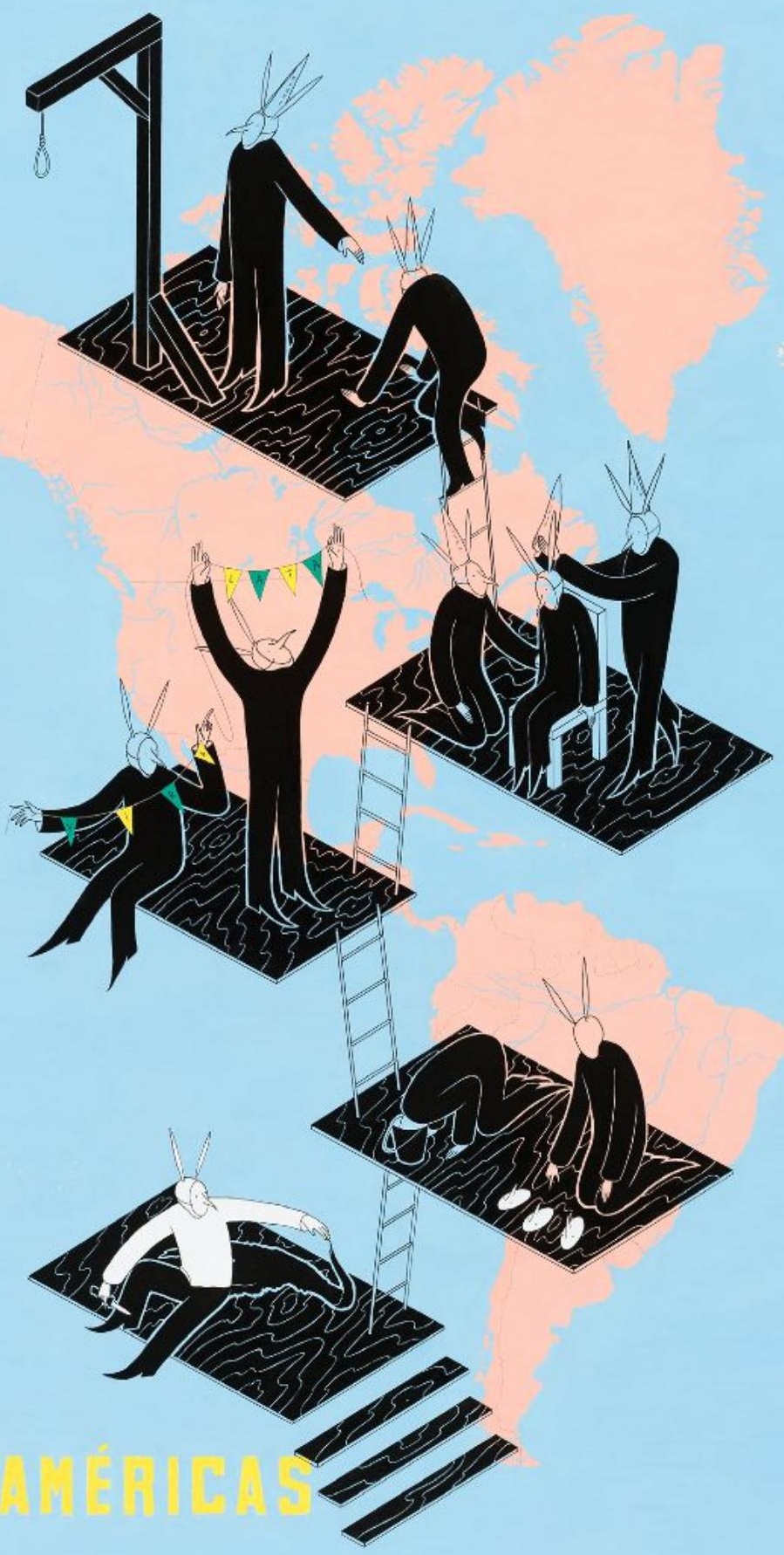

Nelson Rodrigues. 2016. Da série As Américas. Nanquim e acrílica sobre papel. $101 \times 72 \mathrm{~cm}$. 


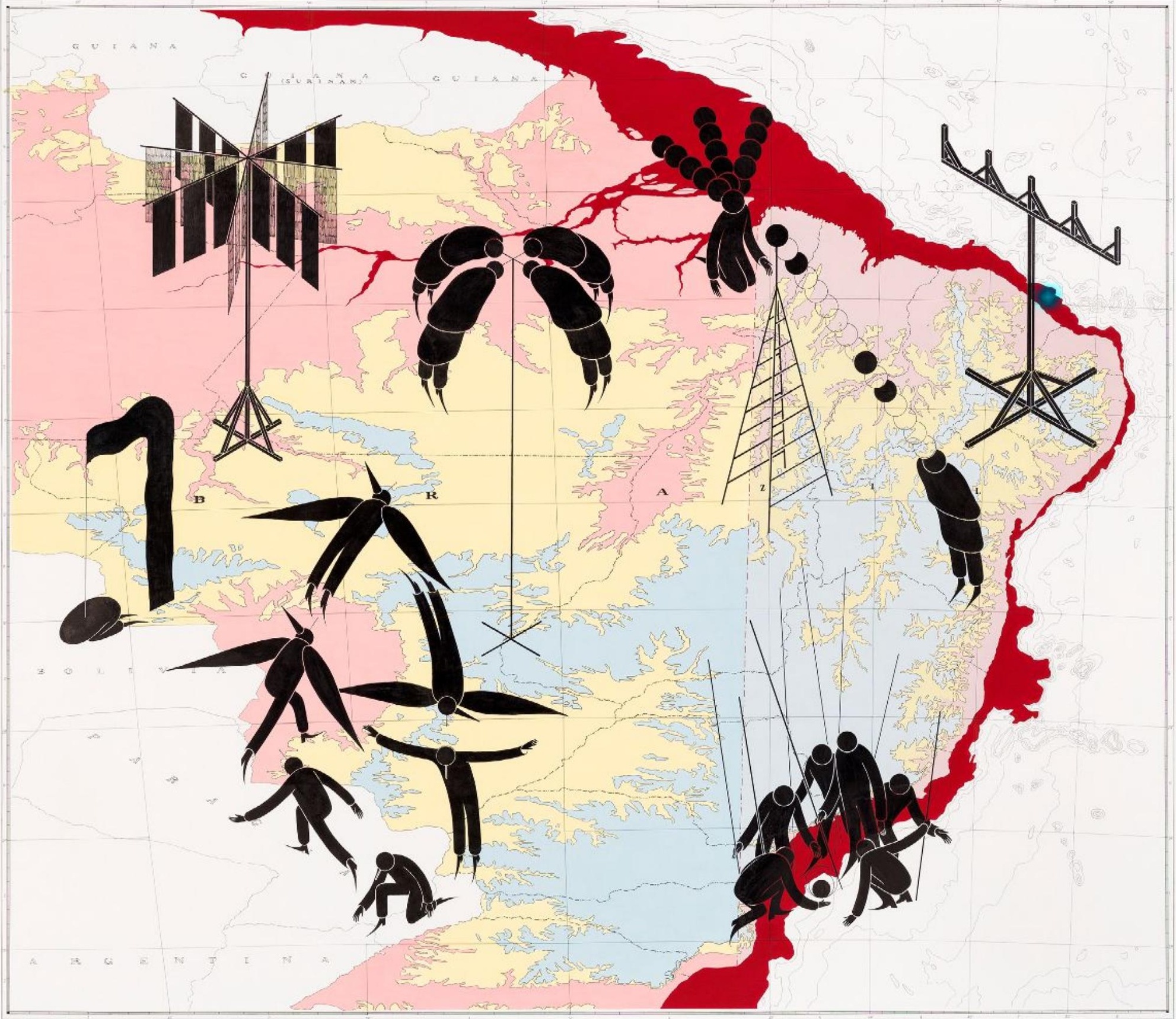

Sem Título. 2018. Guache e nanquim sobre papel. $125 \times 115 \mathrm{~cm}$. 


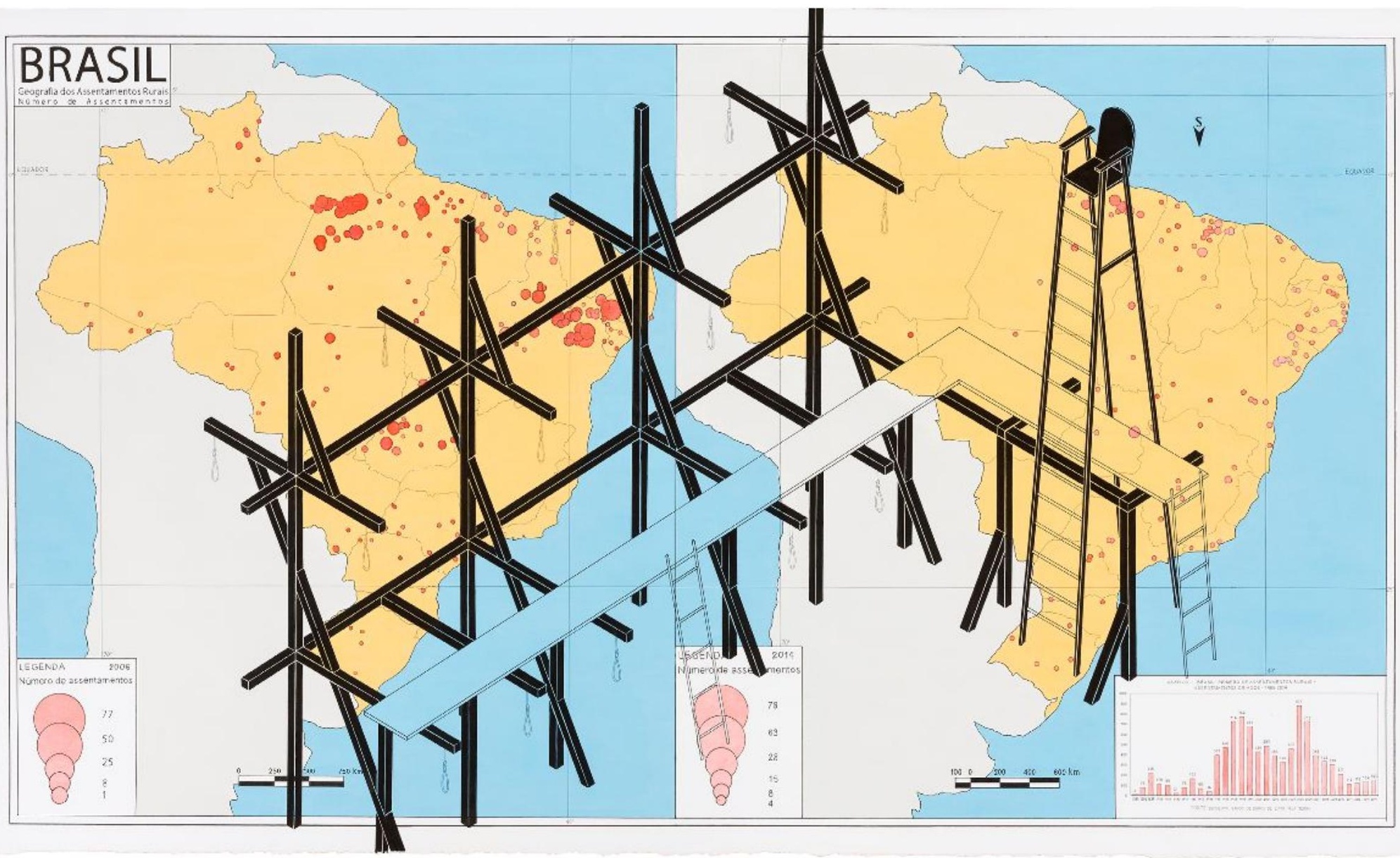

Sem título. 2016. Nanquim e acrílica sobre papel. 59 × 100 cm. 


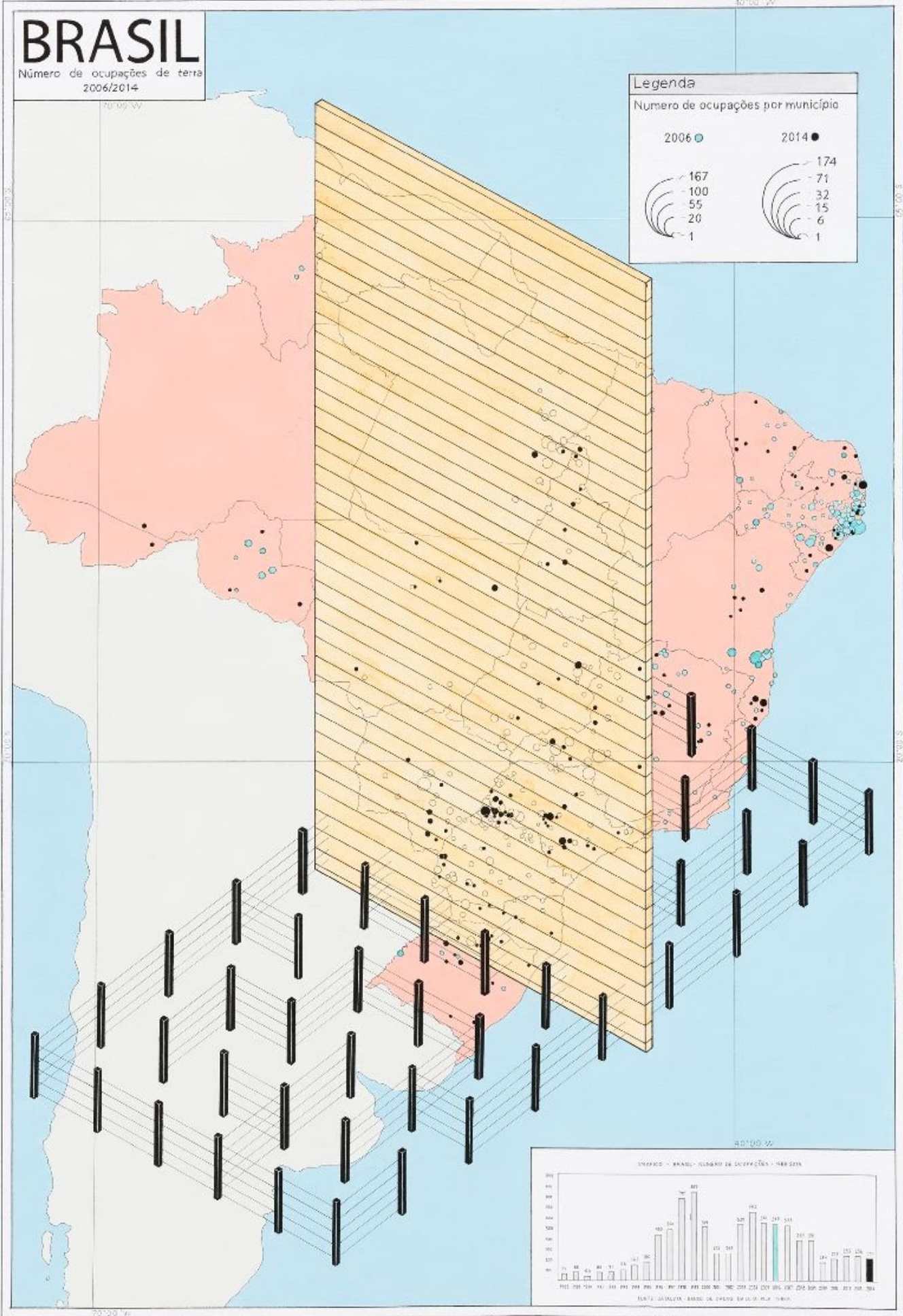

Sem título. 2016. Nanquim e acrílica sobre papel. $72 \times 50 \mathrm{~cm}$. 


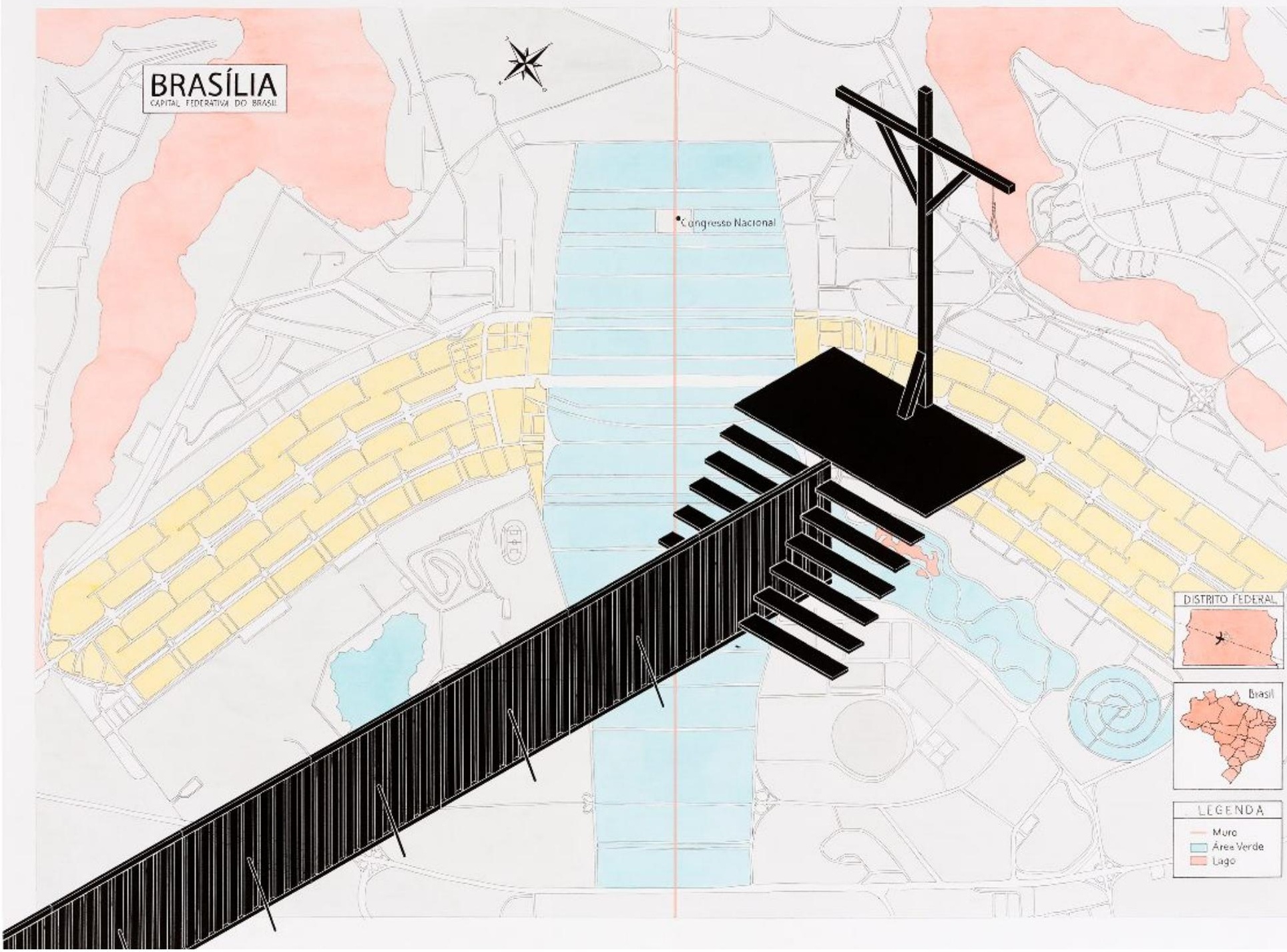

Sem título. 2016. Nanquim e aquarela sobre papel. $72 \times 101 \mathrm{~cm}$. 
Sem título. 2016.

Nanquim e

aquarela

sobre papel.

$87,5 \times 65 \mathrm{~cm}$.

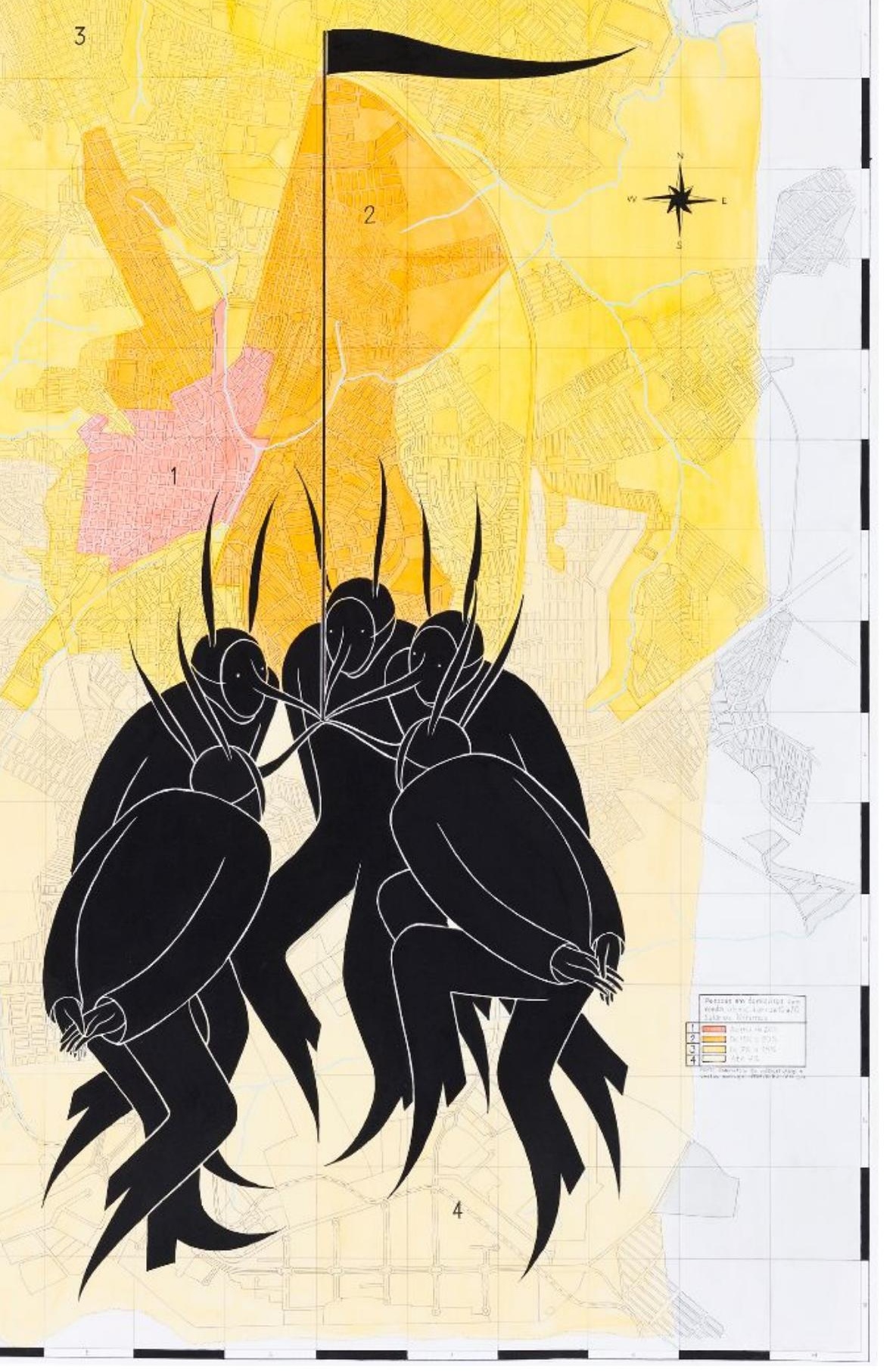




\section{PONTEIROS DE BRASIL \\ 123 pointers of Brazil \\ 123 agujas de Brasil}

Elilson [Universidade de São Paulo, Brasil] ${ }^{*}$

ELILSON. 123 ponteiros de Brasil. Revista Poiésis, Niterói, v. 23, n. 39, p. 115-131, jan./jun. 2022. [DOl: https://doi. org/10.22409/poiesis. v23i39.52953]

\section{Este documento é} distribuído nos termos da licença Creative Commons AtribuiçãoNãoComercial 4.0 Internacional (CC-BYNC) (c) 2022 Elilson
RESUMO Neste texto, que intercruza características dos gêneros crônica e relato, desdobro em escrita o trabalho "123 ponteiros", realizado em 2021. Concatenando performance, memória oral, produção serigráfica, arte postal e arte correio, o mote do trabalho era promover uma rede de contação de histórias sobre o Juquery, colônia psiquiátrica que teve o serviço de internação de permanência desativado no início de 2021, após 123 anos de funcionamento ininterrupto. No trabalho, o número 123, além de se referir a esse marco temporal, indica a quantidade de pessoas que receberam telefonemas, mensagens de voz ou foram interpeladas nas ruas de Franco da Rocha para partilhar ou ouvir memórias sobre o Juquery, como se cada participante fosse um ponteiro mobilizador da História sempre em curso. Enquanto descrevo as ligações e agrupo as falas das pessoas interlocutoras, sugiro reflexões sobre as noções de escuta e existência.

PALAVRAS-CHAVE Juquery; memória oral; arte postal; arte correio.

* Elilson é artista, pesquisador, professor e doutorando em Artes Visuais na USP. E-mail: elilson@hotmail.com. Orcid: https://orcid. org/0000-0001-7974-6304 
ABSTRACT In this text, which intersects both chronicle and narrative characteristics, I unfold in writing the work "123 pointers", performed in 2021. By concatenating performance, oral memory, silk screening and mail art, the work aims to promote the storytelling about Juquery, a psychiatric colony that has ended its confinement program in 2021, after 123 years of continual functioning. The number 123 not only refers to this timeframe, but also indicates the amount of people that received phone calls, voice messages or that were consulted in the streets of Franco da Rocha in order to share and hear memories about Juquery, as if each participant was a pointer and a mobilizer of the ongoing History. While I describe the phone calls and assemble the participants' speeches, I take note on some reflections about the concepts of listening and existence.

KEYWORDS Juquery; oral memory; postal art

RESUMEN En este texto, que conecta características tanto de la crónica como de la narrativa, elaboro en forma escrita el trabajo "123 agujas", realizado en el año de 2021. Concatenando performance, memoria oral, serigrafía y arte postal, el trabajo busca promover la narración de cuentos sobre Juquery, colonia psiquiátrica que cerró su programa de internación permanente en 2021, tras 123 años de funcionamiento ininterrumpido. El numero 123 no solo se refiere a este marco temporal, pero también indica la cantidad de personas que recibieron llamadas telefónicas, mensajes de voz o que fueron consultadas en las calles de Franco da Rocha para compartir y escuchar memorias sobre Juquery, como si cada participante fuera una aguja y un movilizador de la Historia siempre en curso. Mientras describo las llamadas telefónicas y agrupo los diálogos con los participantes, reflexiono sobre los conceptos de escucha y existencia.

PALABRAS CLAVE Juquery; memoria oral; arte postal 
"Esses ponteiros, como a vida, fluem, ainda que pareçam parados". Esta frase é uma tradução livre da inscrição em latim gravada no relógio da Torre Central do Juquery, complexo hospitalar e colônia psiquiátrica fundada em 1898 na cidade de Franco da Rocha, município da região metropolitana de São Paulo. Tal sentença foi o mote para o trabalho "123 ponteiros", que realizei - juntamente a mais de uma centena de vozes que compõem o presente texto - entre agosto e setembro de 2021 como parte da programação da $4^{a}$ edição do festival de artes Soy Loco por ti Juquery?

Em 2021, ano marcado pela desativação do serviço de internação psiquiátrica de permanência após 123 anos de funcionamento, o festival frisou, em sua chamada aberta para intervenções, esse processo de transformação do Juquery. Concebi, então, "123 ponteiros" como uma ode a esse marco temporal. A ação concatenou performance, história oral, escrita, produção serigráfica, arte postal e arte correio. O número 123 é indicativo da quantidade de pessoas - moradores e ex-moradores de Franco da Rocha e arredores, agentes culturais, funcionários e ex-funcionários do Juquery - para as quais telefonei de supetão, troquei mensagens de voz ou abordei nas ruas de Franco em duas visitas.
Nessa rede multivocal, as pessoas partilharam suas memórias mais marcantes em relação ao Juquery, bem como previsões e provisões, isto é, desejos de ações e indicações do que pode se tornar esse espaço, agora em franca disputa simbólica, discursiva e política. Posteriormente, cada um dos 123 participantes recebeu - a maioria via correios: interlocutores por chamadas e mensagens de voz; uma parte pessoalmente: transeuntes abordados nas ruas de Franco da Rocha - um envelope contendo um cartão metalfilm [espelho] com a frase do relógio impressa em serigrafia, além de uma carta relatando algumas das conversas, memórias, confissões e vontades expressas nos telefonemas e trocas de áudios. Em linhas gerais, o intuito era, via voz, estabelecer uma espécie de engrenagem poética e política para agrupar um recorte de imaginários e imaginações sobre o Juquery, simbolizando cada participante como um ponteiro mobilizador dessa História sempre em curso.

Assim, relatarei a seguir um conjunto das histórias que conheci ao pé do ouvido. Memórias e partilhas encadeadas por timbres que me fizeram não só imaginar minúcias dos rostos, gestos e espaços domésticos de quem eu escutava, mas também restituir estradas, corredores, pavi- 
Ihões, alas e pacientes do Juquery em diferentes épocas. Talvez essa constituição visual aconteça também para você ao ler este texto, afinal, a oralidade permite que façamos uma espécie de cinema de voz: a contação, a prosódia, as entonações, as pausas e as hesitações geram a dramaturgia de imagens no pensamento.

Ao acionar dramaturgia e imagem, aproveito para deixar evidente o fato de este texto ser um recorte mínimo: não há pretensão nem mesmo possibilidade de, aqui, refletir a densidade e a multiplicidade de camadas inerentes ao Juquery: complexo de sucessivos apagamentos, que nos anos 60 e 70 já chegou a ter mais de 15 mil pessoas internadas de uma só vez. Nesta massa, não só enfermos mentais, mas todos aqueles que, como me disseram algumas interlocutoras, "não deveriam ser vistos socialmente": prostitutas, mães solteiras, negros, homossexuais, transexuais, imigrantes, retirantes, alcóolatras, pessoas desabrigadas, desorientados pela Guerra, presos políticos... Enfim, um "depósito de indesejados e execrados", uma "dispensação de gente que não servia ao sistema", um "centro oficial da eugenia", uma "parte do holocausto brasileiro"2 outorgado fora acima da lei por um Estado que utilizava o Juquery como "depósito de gente renegada e excluída", como um centro de operação institucionalizada do racismo e das demais violências estruturais. Em outros termos, podemos adjetivar o Juquery como uma parcela significativa deste "indigesto trópico", expressão certeira utilizada pelos editores deste dossiê, visto que estamos falando de 123 anos de história de Brasil.

Além dos tantos episódios de apagamentos da vida intensificados ao longo das décadas por incêndios, destruição de arquivos e registros de torturas, em um lugar em que não foi incomum funcionários se tornarem pacientes ${ }^{3}$, este texto-coro também reúne um clamor das pessoas para que se enxergue a convivência entre dor e alegria no Juquery, onde "também havia e há muita beleza por trás das paredes", vide a relação de amizade entre muitos funcionários e pacientes, os festejos realizados coletivamente, as faturas de natureza entre as alas do complexo e a expressividade dos artistas internos, cujas obras compõem o acervo de mais de 8000 obras do Museu de Arte Osório Césarł .

Em meio a tantos episódios de descaso e horror, também ficou evidente nas conversas que compuseram este trabalho o elo afetivo das pessoas com o Juquery: não só por parte dos moradores de Franco da Rocha, que em sua maioria absoluta se referem ao espaço com 
o codinome "Juca", quase como se falassem de um membro da família, mas também das pessoas que trabalharam no hospital entre a década de 60 e os anos 2000, cujos relatos desvelam, a partir da confusão pronominal típica do ato de rememorar, a vivacidade das lembranças: lá no Juquery muitas vezes virava aíou aquino Juquery na mesma frase. Antes de vocalizar esse conjunto de imagens localizadas verbalmente no tempo, agradeço a atenção dos que fazem e leem esta revista, não deixando de pedir licença a todas as vozes que compõem este trabalho: as nossas e as dos vivos e mortos que passaram pelo Juquery, incontáveis nomes sem corpos e inumeráveis corpos sem nomes, que são vivazes na memória da cidade, de quem passou na cidade e, agora, talvez também na nossa.

Pessoas que nasceram no Juquery, caminharam por suas áreas verdes, trabalharam nas alas psiquiátricas e administrativas, visitaram familiares internos, utilizaram serviços hospitalares e escolares, frequentaram padaria e biblioteca, realizaram ou foram espectadores de ações artísticas, famílias inteiras que trabalhavam no "Juca", pessoas que se apaixonaram e se assustaram em seus corredores e pavilhões... As memórias confiadas vão de questões muito ínti- mas a relações afetivas, abusivas, profissionais e vivências cotidianas. Para muitas pessoas, o que se finca é sensorial: o preparo da massa e o cheiro do pão assando na padaria do hospital; o aroma da grama bem molhada pela chuva; os cupinzeiros alaranjados em contraste constante com a vegetação bem, bem verde; o barulho da fonte de água; uma árvore nascida e presa no teto; o odor de creolina e urina do pátio; matiIhas de cachorros soltos e latindo pelo espaço; abacates e jabuticabas colhidos e caídos pelas vias de terra; os sussurros dos internos por trás dos muros ou os gritos de apelo dos que imploravam, por trás das celas, ajuda para ir embora

Para outras, as memórias mais intensas são as fachadas dos prédios, as escadarias da biblioteca e os paredões dos pátios. A maioria se recordava, ou seja, trazia de volta ao coração ações coletivas: peças de teatro, contações de histórias e festas com os pacientes; visitas ao Museu e excursões escolares; feiras de artesanato, bicicletadas e piqueniques; conversas com os internos que caminhavam pelo Juquery ou com os que circulavam uniformizados pela cidade e tentavam, sem sucesso, embarcar no trem rumo à Estação da Luz.

Logo na primeira ligação, efetuada para um agente cultural de Franco da Rocha integral- 
mente interessado e dedicado à preservação memorial do que aconteceu por mais de um século naquele espaço, entendi que a matéria crucial deste trabalho é o princípio de que a História pode ser reinventada pelo elo de nossas memórias. Mesmo que seja impossível alterar o passado, nosso ato de seguir contando demarca o que deve ser cultivado e o que não deve ser repetido. Como ele me disse, o Juquery é um espelho do Brasil e, no caso de Franco da Rocha, todas as narrativas, como um rio, desaguam ali. Após descrever as primeiras vezes que pisou ainda criança no Juquery e as primeiras coisas que leu a respeito já adolescente, me fez um pedido: de que todo mundo que viesse a ler sobre nossa conversa tivesse em mente que, caso um dia visite o Juquery, ande a esmo pelo espaço e pare onde sua intuição decidir. Feche os olhos, respire profundamente e pense em cada pessoa que foi presa ou que morreu naquele lugar, balbucie cada história que ainda não foi contada.

Nas semanas subsequentes, entre ligações recusadas, números fora das áreas de cobertura, mensagens de voz respondidas, áudios ignorados, telefonemas prolongados e chamadas lacônicas, compreendi que a espera é um substrato da escuta, e isto é um aprendizado de corpo todo: a prontidão da coluna enquanto o braço segura o telefone, em viva voz, às beiras das orelhas; o pescoço curvado, os olhos estatelados e os dedos pressionando os lábios quando o relato contado do outro lado da linha emudece por pavor ou encantamento; as palmas das mãos suando em ânsia e a frustração dos ombros caídos para baixo quando a chamada dispara ou as ligações são repetidamente declinadas; o sorriso desenhado por completo no rosto e o olho passeando pelas paredes esboçando a curiosidade-desejo de querer constituir o rosto por trás do timbre; a lombar afundada, após horas de mensagens a fio, como se a cadeira virasse o próprio charco que se traduz pelas retóricas: Como isso pôde acontecer? 0 que é [im]possível depois disso? Os tímpanos e as pálpebras latejando simultaneamente quando se escuta algo completamente novo...

Ouvi que o primeiro interno do Juquery foi, possivelmente, um escravizado alforriado. Houve a funcionária que, sendo admitida em 1982, afirma ter se deparado com 17 mil internos, mas é de 2 deles que se lembra todos os dias: um idoso que nunca falava e tinha uma tatuagem-marca de um campo de concentração nazista; e uma japonesa bem velha, fugida da Guerra para o Brasil, mandada do Porto de Santos direto para 
o Juquery, que todo dia e o dia todo gritava uma única frase: が私をここから連れ出します! [Darekaga watashi o koko kara tsuredashimasu!]5.

Ouvi sobre um pai e avô internado compulsoriamente por "alcoolismo" e impedido de viver com sua família por mais de quatro décadas. Houve uma funcionária ainda em atuação que repetiu três vezes a importância de não esquecermos dos torturados pelos choques elétricos e pela hidroterapia no porão e na rotunda. Ouvi de outra trabalhadora sobre as denúncias sociais presentes nas obras da artista e paciente Aurora Cursino; a mesma funcionária me disse que tudo que ela é hoje, na vida, deve a outra paciente-artista: Cidinha. Houve o adolescente que conclamou que a história deve ser mantida com força. Ouvi de uma senhora que se um espaço está em decomposição, a memória se esfarela. Houve um paciente que viveu 86 anos no Juquery e só no final da vida, faltando mesmo pouquíssimos anos para morrer, conheceu o que é viver fora. Ouvi que todos os presos políticos da ditadura militar saíram do Juquery sem vida.

Houve um cobrador de ônibus que levava e buscava os funcionários, sempre com uma caneta bic encaixada na orelha e o sorriso mais largo que se vê na vida. Ouvi que o Juquery é um lugar constantemente antiguecendo. Hou- ve uma árvore que nasceu do teto, em uma das alas, que mudou por completo o pensamento do jovem artista em relação àquele espaço. Ouvi o rapaz que, por pura vontade, passou dez dias acampado na área livre do Juquery e até hoje diz sentir a presença da multidão de machos que pintaram miséria naqueles prédios. "É mais de um século de afetação masculina incrustrada, você quer o quê?!". Houve a mesma árvore que brotou do teto sendo sumariamente arrancada. Ouvi os cachorros soltos pelas áreas de convivência, latindo sem parar.

Houve o professor que saía de uma escola próxima e entrava escondido para recolher abacates. Ouvi os internos que andavam soltos, cumprimentando a todos como se os conhecessem há muito tempo. Houve uma pinguela - ponte rústica de tronco que servia de atalho entre algumas alas - que transmitia uma firmeza de quem nunca iria cair. Ouvi um ex-segurança que não se lembra de absolutamente nada, nada, nada, nadica de nada, tudo se apagou, e que não desmente por mágoa, só não lembra mesmo. Há o ex-padeiro do hospital que até hoje esfrega as mãos e sente o cheiro da massa de pão. Ouvi que o universo da loucura te acompanha desde menino se você nasce em Franco da Rocha. Houve um 
paciente que produzia bolas de meias para as crianças da cidade. Ele pedia meias para todo mundo, e bastava que você fosse lá e dissesse que tinha crianças para presentear, que preparava as bolas, que eram fantásticas, durinhas, tanto que até pululavam quando batiam no chão! Ouvi que um menininho vivia perguntando: "Como ele pode ser de carne e osso e fazer bolas de meia? Ele deveria ser de pano também!". Houve um carimbo no uniforme de brim amarelo desse paciente que identificava seu setor: Departamento de Psicopatas II.

Ouvi sobre os pacientes que passeavam "semi-livremente" pela cidade, porque o uniforme do hospital psiquiátrico limitava seu percurso e impedia o acesso ao trem. Houve um funcionário que montou uma peça de teatro nos anos 1970 chamada "Os loucos vêm de fora", tentando expressar a visão do louco para o mundo e não do mundo para o louco. Ouvi que quando o trem parava na estação Franco da Rocha os passageiros sempre gritavam em coro: "Quem é louco desce aqui!". Houve o mesmo funcionário dizendo que o Juquery era apenas a central de recolhimento, pois todos os loucos vinham de fora. Ouvi outra funcionária dizendo que fundou um grupo de intervenção artística chamado "Loucos pela vida". Houve minha comoção ao identificar, em telefonemas distintos, dois funcionários que acharam amor no meio do movimento grevista e se enamoraram por anos nos corredores do Juquery, mas que há décadas não se falam ou se veem. Ouvi de um rapaz que o Juquery é uma fábula fantástica impossível de ser traduzida.

Houve a enfermeira que fez uma prece em voz alta na noite em que caiu a energia geral e ela estava sozinha numa sala com vários internos. Ouvi as risadas da mulher que frequentava quando criança todas as festas que seu pai e sua mãe, ex-funcionários, promoviam mensalmente para os pacientes. Houve a servente que já chegou a distribuir comida sozinha para mais de 700 pacientes, e que ainda chegou a levar pontapés na barriga grávida da paciente mais bonita, a que ficava reinando num quintal. Ouvi a voz embargada da funcionária que se emociona só em dizer a palavra Juquery, e que ainda se lembra da temperatura do sol de 20 de março de 1974, o primeiro dia dos 34 anos em que trabalhou ali. Houve Altina, a paciente que mais a ajudava, que não saía de perto de jeito nenhum, que tinha a risada mais gostosa e alta do Juquery, e que um dia pediu uma Coca-Cola bem gelada, dizendo que era seu último dia. "E você vai embora pra onde, 
vai receber alta, tá mentindo agora?! E não é que ela morreu naquela noite?". Ouvi sobre os inúmeros pacientes que recebiam alta e simplesmente sumiam e sobre os funcionários que nunca eram informados disso e que, portanto, tinham que aprender a não se apegar. Ademais, "os ciclos são assim, têm ascensão e queda o tempo todo. Se a gente não se apega, na vida se sofre menos".

Houve o rapaz que ao término das aulas de circo e de teatro sempre alisava o tablado, passando a mão na borda toda, de um canto a outro, sendo chamado de maluco pela turma. Ouvi a história da mulher que tinha 11 anos quando a família de 8 pessoas saiu retirante do Ceará, sem qualquer bem ou garantia. Seu tio morava em Franco, tinha amigos que trabalhavam na Colônia e a primeira noite que dormiram em São Paulo foi dentro do Juquery. Ela nem precisa fechar os ol hos para lembrar dos gritos de dor, outros de susto. Houve essa mesma mulher trabalhando na fase adulta no Juquery, mas não conseguindo passar mais de seis anos, já que sofria desde a hora em que entrava. Ouvi sobre a paciente Carol, que andava agarrada com uma boneca, tinha a língua presa e exclamava o dia inteiro: "Ai, credo!". Por amar carne moída, Carol sempre pergun- tava: "Hoje vai ter boi ralado?!". Houve um fato consumado e repetido: a maioria dos pacientes sempre foram as mulheres!

Ouvi sobre um grupo de mulheres que passava o dia fazendo tranças nos cabelos e entoando cânticos divinos. Houve uma psicóloga que só se acalmava quando parava e olhava para elas. Ouvi de sua boca que quando a gente canta acontece uma conexão com uma coisa buscada de dentro, e que ela só não enlouqueceu trabalhando ali, nem virou uma interna, porque todos os dias, antes de botar o primeiro pé dentro, falava em voz alta que não tinha nenhum poder além de preencher prontuários. Houve alguém que caracterizou como tênue a linha entre ser paciente e funcionário. Afinal, "dor e remédio, ali, se tinha de sobra". Ouvi o barulho das moedinhas sendo arremessadas no chafariz e os gritos de "vai voar cocô!", quando se esquecia do perigo e se passava bem perto do muro alto que beirava o pronto-socorro. Há quem diga que o arremesso de merda era simultaneamente um jogo e um recado dos pacientes. Ouve-se sempre um monte de vozes falando ao mesmo tempo.

Há a moradora que só anda no Juquery uma vez por ano a fim de ver o pai, que era funcionário e virou interno, em todos os cantos. Ouvi que 
para trabalhar num lugar assim e permanecer bem, você tem que fazer com que o coração esteja sempre fervendo. Houve Jandira de Paula, paciente crônica, que conscientemente tinha muitos rompantes e quebrava todos os vidros só para ser mandada para a rotunda e gozar do "direito de estar sozinha". Ouvi uma mulher que adotou dois pacientes que não tinham ninguém, e eles moraram com sua família até a morte. Havia o paciente Ambrósio, de dois metros de altura, que tremia de medo assim que avistava Mané, um dos menores dentre todos os internos do Juquery. Houve também Pequenininho-grandão, um paciente que se apresentava assim, porque sempre se comparava às crianças. Ouvi o "bom dia, Santa Rita" que a funcionária falava diariamente, quantas vezes passasse em frente à capela. Há o relato sobre o "banal inexplicável" que é ver o exato momento em que a fonte de água seca, justo na última visita para o avô, que viria a morrer em fração de minutos. Ouvi o som de helicóptero, que às vezes abafa e acalma os gritos dos pacientes. Ainda mais alta que o motor e as hélices foi a voz de uma professora que falou do dever e da necessidade de entendermos os internos das colônias psiquiátricas brasileiras como nossos antepassados.
Houve um professor que, sorrindo, falou que pensar em termos de Juquery é ver os rostos de Mário Pacanaro e Ranulfo Faria, artistas que sempre encantaram o lugar com suas músicas. Ouvi a moça que foi um bebê deixado no Juquery, seu símbolo mor de origem e gatilho. Houve a psicóloga que fazia treinamento no Complexo e pairou o olhar na janela da sala de aula a elaborar o trauma de um suicídio recente. Ela ouviu uns pratos sendo jogados contra a parede e finalmente percebeu estar muito perto do pátio, lugar que simbolizava, para ela, o contrário de uma das principais lutas do campo da psiquiatria: não tratar a doença mental com encarceramento. Houve as detentas que alisaram bastante seu cabelo. Ouvi sobre o medo que o filho de uma funcionária tinha ao ver as dezenas de pacientes nus. Houve também os pacientes com os uniformes bem alinhados, que saíam diariamente pela cidade para pedir cigarro e conversar com os taxistas.

Ouvi sobre a internação de uma estrangeira cadeirante, "canadense ou alemã", que aprendeu um pouco de português e contava que foi parar ali somente porque se apaixonou por um rapaz de outra classe social. Há rumores de que ela certamente morreu só. Havia o funcionário que ordenava que a filha tapasse os olhos ao entrar em sua ala de trabalho, porque os internos 
sempre estavam despidos. Ouvi seu resmungo de ironia ao confessar que sempre espiava, bem como seu suspiro prolongado tanto ao lembrar do dia em que flagrou um homem levar eletrochoques num porão, quanto a imitar os gritos que nunca saem de sua cabeça. Houve a funcionária que conversava diariamente com os "inofensivos", pacientes que circulavam livremente entre os moradores da cidade, pedindo que telefonassem para algum familiar, pois estavam ali sem qualquer motivo e contra suas vontades. Ouvi que sua vontade era escrever uma carta ao Estado até descobrir, prontuário por prontuário, que aquelas prisões eram ações do próprio Estado. Houve Gertrudes, a paciente que todo domingo ganhava macarronada com galinha caipira da prima que religiosamente a visitava. Ouvi de uma estudante secundarista que o Juquery não pode ser resumido e restringido à ideia de reserva ambiental. Houve um homem que proclamou que um povo que não olha para a história vive fadado a repeti-la: os eletrochoques voltaram a circular como itens nas listas de equipamentos em documentos oficiais do Governo Federal em 2019. Ouvi que o Carandiru e o Juquery foram projetados pelo mesmo escritório de arquitetura, Ramos de Azevedo. Houve uma faixa erguida pela voz:

\section{DIFERENÇANÃOÉ DOENÇA.}

Na última mensagem de voz recebida, descobri a história da funcionária, que, crente de que estava grávida de um menino, até os nove meses era interpelada diariamente por uma paciente que a parava nos corredores para entoar: "O nome dela é Jéssica, eu já falei para você". O refrão, que aparentemente sinalizava o principal sintoma clínico daquela mulher, que foi internada pelo simples fato de não parar de cantar, acabou batizando a filha, que nasceu sem nome, visto que supostamente seria um garoto. Hoje, Jéssica estuda canto e trabalha como cantora. Livremente, conta e canta.

Andando pelas vias do Juquery, após assistir às últimas rodas de conversa e ações memoriais do Festival e distribuir envelopes para participantes e transeuntes, me peguei cantarolando "Jéssica" no pensamento ao tentar burlar as regras de segurança patrimonial e me aproximar do relógio da torre central, com o desejo de fotografá-lo refletido em um dos postais. Após aparentemente ludibriar uma das seguranças, presenteando-a com um envelope, isto é, como um dos 123 ponteiros, consegui alcançar o pátio da torre central. Eram $17 h 13$ quando outra segurança, após receber a informação por rádio, se aproxi- 
mou para coibir o acesso. O relógio badalou

um estrondo fora de compasso e de hora.

Inexplicável, segundo a própria segurança . Tentando pontuar este texto, lembrei-me há pouco de uma ex-funcionária, que me disse ao telefone que a memória é uma invenção. Ela lançou, por fim, uma pergunta que não pude responder no dia, tampouco o farei aqui: "Falar sobre a história faz a gente mover a história?". Por hora, me agarro à tentação sonora de afirmar que escuta e existência são cognatos políticos.
NOTAS

1 tífulo do festival é grafado dessa maneira, sem se separar o termo Juquery por vírgula, como vocativo. Desde sua primeira edição em 2018, o festival se propõe a ocupar o espaço do Juquery com ações artísticas, rodas de conversa, exibições de filmes, dentre outras atividades, com o objetivo de frisar a relação fundamental entre arte e psiquiatria que perpassa a história desse lugar, bem como estabelecer diálogos e reconstituir coletivamente as memórias em torno do Complexo, tentando ressignificar, em seu tífulo, a carga semântica negativa atrelada ao termo "louco" e, consequentemente, o estigma de loucura associado à cidade de Franco da Rocha e aos seus moradores. Conheça mais em: home. | SoyLocoPorTiJuquery

2 Todas as frases grafadas entre aspas neste texto são de autoria das pessoas com as quais conversei por telefone.

Embora eu as liste no final do texto, como agradecimento geral, preservo suas identidades em frases específicas por dois motivos: frisar a polifonia como matéria principal deste trabalho e respeitar o desejo de anonimato de alguns participantes. A expressão "holocausto brasileiro", de modo particular, se refere ao título do livro da jornalista Daniela Arbex, que retrata os inúmeros crimes contra a humanidade praticados no Hospital Colônia de Barbacena, cujo histórico se assemelha bastante ao que ocorreu no Juquery.

3 Dentre os inúmeros artigos acadêmicos e dossiês investigativos sobre o Juquery, deixo aqui dois títulos de livros que podem interessar à leitora e ao leitor para ter dimensão desses bastidores: "Cinzas do Juquery: os horrores do maior hospital psiquiátrico do Brasil", colaboração entre José da Conceição, 
ex-funcionário e o jornalista Daniel Navarro Sonim, e "O espelho do mundo: Juquery, a história de um asilo", da autora Maria Clementina Pereira Cunha.

4 Localizado e sediado no acesso ao Juquery, o Museu é intitulado com o nome do médico que atuou como psiquiatra no Complexo Hospitalar por mais de quatro décadas, sendo um dos pioneiros no Brasil da aplicação da arte terapia a pacientes psiquiátricos. Fundou e dirigiu a Escola Livre de Artes Plásticas, que funcionou no hospital entre as décadas de 50 e 70. Após um período de mais de dez anos fechado por conta dos impactos de um incêndio no prédio administrativo do Juquery, o museu passou por um processo de restauro e foi reaberto ao público em 2020, com uma exposição permanente de desenhos, pinturas e esculturas produzidas por internos, muitas dessas obras de autoria desconhecida.

Fontes: https://masp.org.br/exposicoes/historias-da-loucura-desenhos-do-juquery http:/ francodarocha.sp.gov.br/franco/artigo/noticia/9966 Acessos em: 08 nov. 2021.

5 Alguém me tira daqui!

6 Agradecco ao Caio Henrique Ramos, que viveu comigo este instante, e que colaborou na confecção das centenas de envelopes, assim como os amigos Gilson Rodrigues e Mayara Millane. Agradeço imensamente àquelas e àqueles que gentilmente atenderam os telefonemas, ouviram as mensagens de voz e decidiram, timbre por timbre, partilhar como compõem o Juquery: Matheus, Renata, Fernando, Silvia, Luana, Edmar, Edna, Regina, Thiago, Amanda, Priscila, Rafaela, Bruna, Kadhija, Vanda, Laudy, Yuri, Silvia, Carlos, Juliana, Ágata, Ednaldo, Gilvan, Sandro, Neiva, Tânia, Eda, Maria, Jesuína, Danilo, Olive, Styven, Erineide, Ranulfo, Aparecida, Vanessa, Larissa, Cássia, Pedro, André, Maria, Marlene, Giselle, George, Regina, Uendel,
Vanessa, Cida, João, Sílvia, George, Renata, Patrícia, Regiane, Ana, Regiane, Sueli, Douglas, Josafá, Silmaria, Simone, Marcelo, Edgar, Iraci, Elaine, Natasha, Andrea, Sílvia, Elaine, Jéssica, e a todas as pessoas que encontrei caminhando por Franco da Rocha e pelo Juquery. Agradeço por fim, e de modo especial, à equipe do festival. 




Flyer de divulgação do projeto 123 ponteiros. Fonte: Festival Soy Loco Por Ti Juquery 




Exemplar do postal espelhado e carta enviados via correios ou distribuídos pessoalmente no festival em envelopes carimbados com o título do trabalho. Foto: Maria Capai] 


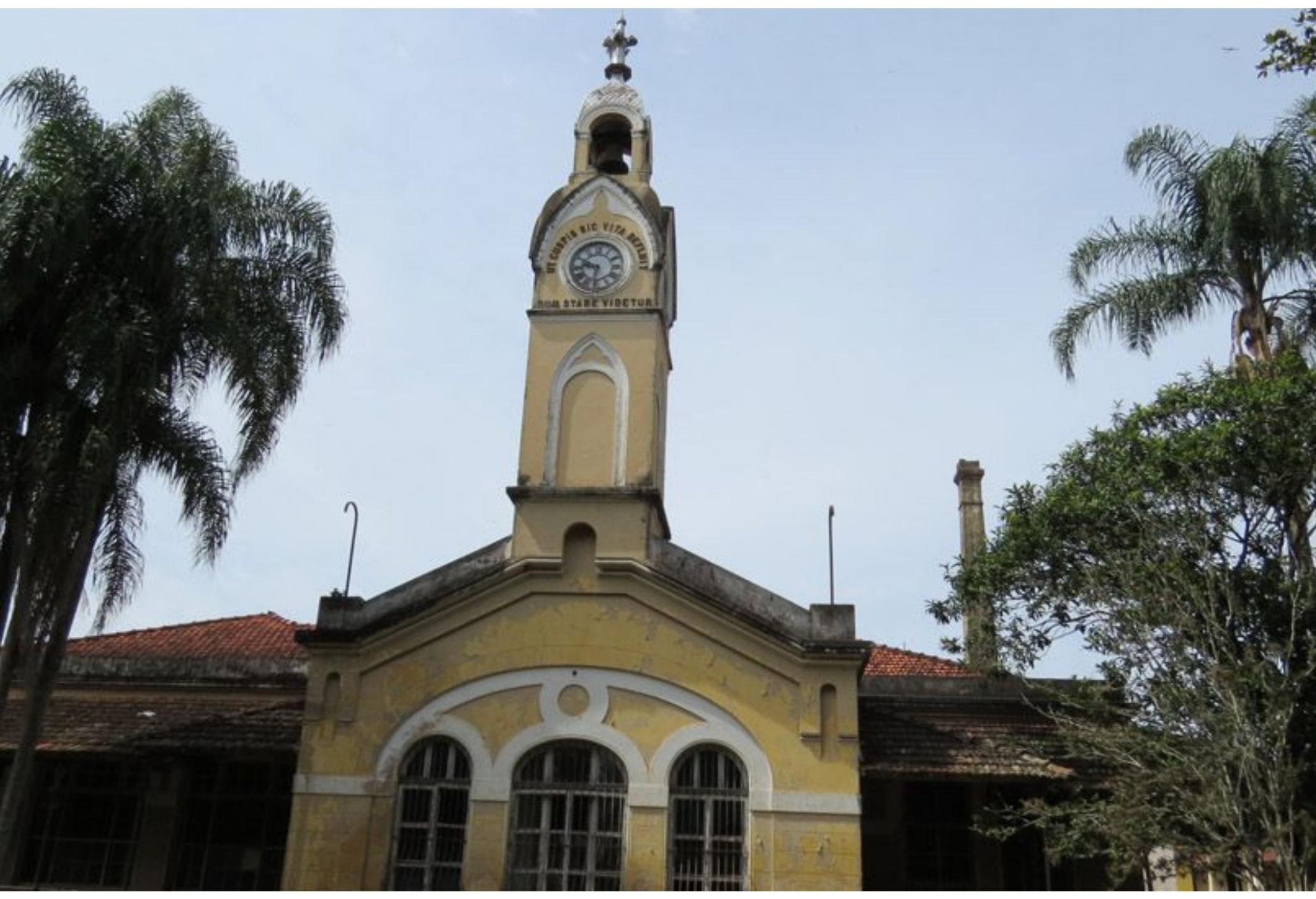

Crédito: Portal Regional News. Relógio do Juquery voltou a funcionar após décadas parado [rnews.com.br] Acesso em: 18 set. 2021] 


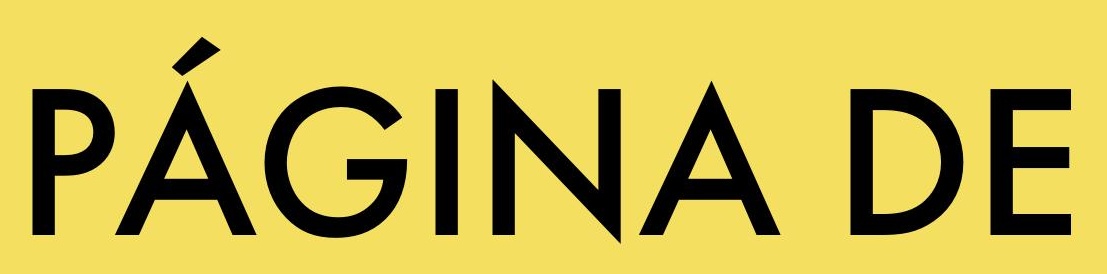
ARTISTA 


\section{CONTROLE DE GÊNERO}

Gender Control

Control de Género

> Leona Machado [Universidade Federal Fluminense, Brasil]*

MACHADO, Leona. Controle de gênero (página de artista). Revista Poiésis, Niterói, v. 23, n. 39, p. $132-$ 134, jan./jun. 2022. [DOI: https://doi. org/10.22409/poiesis.v23i39.51933]

Este documento é distribuído nos termos da licença Creative Commons Atribuição Não Comercial 4.0 Internacional (CC-BYNC) (C) 2022 Leona Machado. Submetido: 12/10/2021 ; Aceito: $18 / 10 / 2021$
RESUMO Controle de Gênero é uma obra-pesquisa desenvolvida entre maio e setembro de 2021 sobre relações de gênero e algoritmos de computador em uma abordagem lógico-filosófica. $\bigcirc$ trabalho foi formulado a partir de instruções para quantificar o gênero de 0 a 100 por cento e subsequente reprodução estatística pela máquina. Os resultados, dispostos em listas com horários e porcentagens, são acompanhados por uma análise lógica e reflexão filosófica sobre gênero e os resultados matemáticos obtidos. Em suma, consiste em um tratado não-binário de gênero.

PALAVRAS-CHAVE gênero, lógica, matemática, filosofia, arte, não-binariedade

ABSTRACT Gender Control is a artwork-research conceived between May and September 2021 about gender relationships and computer algorithms in a logical-philosophical approach. The work was realized from instructions to quantify gender from 0 to $100 \%$ and subsequent statistical reproduction by the machine. The results, arranged in lists with timetable and percentages, are accompanied by a logical analysis and philosophical reflection on gender and mathematical results obtained. In short, it consists on a non-binary gender tract. KEYWORDS gender, logic, mathematics, philosophy, art, non-binarity

RESUMEN Control de Género es una obra-investigación desarrollada entre mayo y septiembre de 2021 sobre relaciones de género y algoritmos informáticos con un enfoque lógico-filosófico. El trabajo se formuló a partir de instrucciones para cuantificar el género de 0 a 100\% y posterior reproducción estadística por parte de la máquina. Los resultados, ordenados en listas con horario y porcentajes, van acompañados de un análisis lógico y una reflexión filosófica sobre el género y los resultados matemáticos obtenidos. En resumen, se trata de un tratado de género no binario.

PALABRAS CLAVE género, lógica, matemáticas, filosofía, arte, no binariedad 
Leona Machado (Leona) é artista-pesquisadore e graduande de Bacharelado em Artes pela Universidade Federal Fluminense. Trabalha com algoritmos de computador e suas possíveis relações com arte, em especial no que tange à formação da identidade contemporânea dentro do contexto técnico e filosófico.

E-mail: Ihgmachado@id.uff.br. Orcid: https:/ / orcid.org/0000-0002-6319-9016 


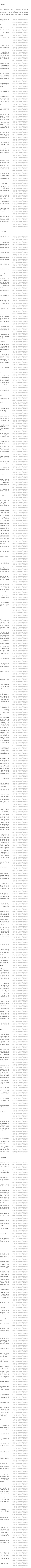


ARTIGOS 


\section{CINZAS, CACOS E RASTROS: APONTAMENTOS SOBRE A NOCÃO DE VESTÍGIO}

Ashes, smithereens and tracks: notes about the notion of vestige

Cenizas, fragmentos e rastros: notas sobre la noción de vestigio

$>$ Daidrê Thomas de Amorim [Universidade Federal do Estado do Rio de Janeiro, Brasil]*

AMORIM, Daidrê Thomas de. Cinzas, cacos e rastros: apontamentos sobre a noção de vestígio. Revista Poiésis, Niterói, v. 23, n. 39, p. 136-154, jan./jun. 2022. [DOI: https://doi. org/10.22409/poiesis.v23i39.49094]

Este documento é distribuído nos termos da licença Creative Commons Atribuição-Não Comercial 4.0 Internacional (CC-BY-NC) (C) 2022. Daidrê Thomas de Amorim. Submetido: 9/3/2021; Aceito: $25 / 5 / 2021$
RESUMO Este artigo apresenta algumas reflexões sobre a noção de vestígio, a partir de trabalhos artísticos de Claudio Parmiggiani, Alberto Giacometti e Carlos Vergara. São consideradas nesta análise certas perspectivas teórico-críticas de Jean-Luc Nancy e Georges Didi-Huberman. Busca-se pensar sobre possíveis relações entre arte e vestígio, tendo em vista o entendimento da operação artística como algo que diz respeito ou inclui procedimentos destrutivos e de desaparecimento.

PALAVRAS-CHAVE arte; vestígio; destruição; desaparecimento

ABSTRACT This article presents some reflections on the notion of vestige, from the artistic works of Claudio Parmiggiani, Alberto Giacometti and Carlos Vergara. Some theoretical-critical perspectives of Jean-Luc Nancy and Georges Didi-Huberman are considered in this analysis. It seeks to think about possible relations between art and vestige, in view of the understanding of artistic operation as something that concerns or includes destructive and disappearance procedures.

KEYWORDS art; vestige; destruction; disappearance

RESUMEN Este artículo presenta algunas reflexiones sobre la noción de vestigio, a partir de las obras artísticas de Claudio Parmiggiani, Alberto Giacometti y Carlos Vergara. En este análisis se consideran ciertas perspectivas teórico-críticas de Jean-Luc Nancy y Georges Didi-Huberman. Se busca pensar en posibles relaciones entre arte y vestigio, teniendo en vista el entendimiento de la operación artística como algo que concierne o incluye procedimientos destructivos y de desaparición.

PALABRAS CLAVE arte; vestigio; destruición; desaparición

* Daidrê Thomas de Amorim é mestranda em Artes Cênicas pela Universidade Federal do Estado do Rio de Janeiro. E-mail: daidre.thomas@gmail.com. Orcid: https://orcid.org/0000-0002-1868-8646.

Revista Poiésis, Niterói, v. 23, n. 39, p. 136-154, jan./jun. 2022. [DOl: https://doi.org/10.22409/poiesis.v23i39.49094] 
"ELE: Que bonito!...que bonito!...

Ainda que involuntariamente, manteve algo do sotaque dos Grisões... Que bonito! Os olhos se arregalam, o sorriso é amável; referia-se à poeira que cobria todas as velhas garrafas de solvente amontoadas numa mesa do ateliê."

[Jean Genet]

"As coisas da arte começam frequentemente ao contrário das coisas da vida. A vida começa por um nascimento, uma obra pode começar sob o império da destruição: reino das cinzas, recurso ao luto, retorno de fantasmas, necessária aposta sobre a ausência."

[Georges Didi-Huberman]

A primeira citação utilizada como epígrafe deste artigo foi extraída do livro O Ateliê de Giacometti [GENET, 2000], escrito pelo autor e dramaturgo Jean Genet [1910-1986] entre os anos de 1954 e 1957, período em que conviveu intensamente com o artista suíço Alberto Giacometti [1901-1966], frequentando o ateliê do artista e posando para vários de seus retratos. O livro é resultado desses encontros e é constituído de fragmentos, separados nas páginas por espaços em branco. São trechos em que Genet comenta obras de Giacometti, faz algumas reflexões a partir delas e transcreve alguns diálogos que teve com o artista. Nesses diálogos, Giacometti está designado como ELE, enquanto Genet aparece como EU. O texto do livro foi publicado originalmente na revista Lettres Nouvelles e em 1963 foi republicado juntamente com as fotografias de Ernst Scheidegger, tiradas no ateliê de Giacometti entre os anos de 1948 e 1959.

Na época desses encontros, ambos os artistas já eram consagrados: Giacometti realizava exposições retrospectivas pela Europa e Estados Unidos e Genet havia publicado muitos de seus principais livros e peças, incluindo As criadas [1947]. Segundo Célia Euvaldo, responsável pela tradução de O Ateliê de Giacometti para o português, quando os artistas se encontraram pela primeira vez, em 1954, o que chamou a atenção de Giacometti em Genet foi sua calvície, que revelava o formato de sua cabeça.

Giacometti tinha especial interesse pelas cabeças, mas considerava impossível retratá-las, e nessas tentativas desenhou, pintou e esculpiu inúmeras ao longo de sua vida. Genet transcreve uma afirmação de Giacometti: "Jamais conseguirei pôr num retrato toda força que há numa cabeça" [GENET, 2000, p. 72]. Mas foi nesse esforço que o artista trabalhou, muitas vezes apagando o trabalho de dias e dias, e recomeçando o retrato ou a escultura.

O ateliê de Giacometti é descrito por Genet como um espaço pouco iluminado, atulhado de obras e 
materiais de trabalho e coberto de poeira. Para o escritor, isso daria a ver o respeito que Giacometti tinha por todas as matérias, incluindo a poeira, que ele não permitia que sua esposa, Annette, retirasse das vidraças [GENET, 2000, p. 45]. Ainda em relação ao ateliê, ou seja, ao lugar de trabalho do artista mas que também implica em um trabalho do lugar - Genet observa:

Aliás, esse ateliê, ao rés-do-chão, vai desabar de um momento para outro. É de madeira carcomida e poeira cinza, as estátuas são de gesso, deixando à mostra a corda, estopa ou um pedaço de arame; as telas, pintadas de cinza, perderam há muito tempo a tranquilidade que tinham na loja, tudo está sujo e abandonado, tudo é precário e está prestes a desmoronar, tudo tende a se dissolver, tudo flutua [...] [GENET, 2000, p. 92]

Ou seja, tanto as obras de Giacometti quanto o seu lugar de trabalho tocam esta possibilidade de desmoronamento, de apagamento, de dissolução. É sempre uma precariedade que está em jogo, ou uma iminência de destruição. James Lord', em seu livro Um retrato de Giacometti, também fala sobre o ateliê do artista e o descreve de forma parecida com a de Genet:

De tanto posar ali, hora após hora naquele ateliê cinzento, atravancado, empoeirado, a gente começava a sentir que, realmente, todo o futuro dependia da possibilidade de se reproduzir exatamente por meio de pincéis e de pigmentos a sensação visual produzida por um determinado aspecto da realidade. [LORD, 1998, p. 34-35]
A poeira depositada e acumulada pelo tempo é uma menção recorrente nos livros de Genet e de James Lord.

A segunda citação da epígrafe foi retirada do Iivro Génie Du No-Lieu: Air, Poussière, Empreinte, Hantise[2001], em que Georges Didi-Huberman se detém sobre a série de obras intitulada Delocazione, do artista italiano Claudio Parmiggiani [1943-].

A série foi iniciada pelo artista em 1970, com um trabalho realizado na Galleria Civica di Modena [galeria de arte em Módena - Itália], onde se organizava uma exposição coletiva, intitulada Arte e Crítica.

Parmiggiani escolheu trabalhar em um determinado espaço do museu, que era utilizado habitualmente como depósito. Nessa sala, o artista encontrou diversos objetos ali deixados, entre eles obras em caixas de madeira e um pedaço de escada apoiado na parede, juntos a muita poeira [Fig. 1].

Como observa Didi-Huberman:

Ao deslocar os objetos para "fazer o espaço", como se diz - primeiro ato de delocazione, portanto -, o artista foi tomado pela visão, paisagem ou natureza morta, de traços deixados em negativo pela poeira. E foi isso mesmo que ele decidiu, consequentemente, trabalhar. Tratava-se de intensificar, de acentuar, de dar de novo consistência às impressões existentes, e mesmo de criar 
novas por uma escolha processual, material e formal, específica. [DIDI-HUBERMAN, 2001, p. 18]

Assim, Parmiggiani desloca os objetos do lugar onde estavam, revelando a impressão em negativo que deixaram nas superfícies e nas paredes. Essas impressões, efetuadas pelo tempo, e a poeira que se acumulou no espaço, produziram as marcas dos objetos [Fig. 2].

A partir dessa percepção, Parmiggiani fez uma escolha artística: passou a criar impressões, vestígios a partir do fogo e das cinzas. Por meio da queima de pneus em galpões com objetos [cortina, livros nas prateleiras e outros, como crânios e ampulhetas], o artista faz com que a fumaça e a fuligem se imprimam no espaço. Posteriormente, os objetos são retirados de seu lugar, deslocados, e a impressão feita pelas cinzas e pelo deslocamento é tornada visível.

Ao comparar esses dois momentos do trabalho de Parmiggiani, Didi-Huberman afirma que, no caso da poeira que se acumula no espaço, trata-se de uma obra passiva do tempo; já no caso das impressões feitas por meio da fumaça, o que Parmiggiani propicia é uma obra ativa do fogo. Em ambos os casos, o artista implica e trabalha as noções de tempo e de lugar por meio do deslocamento dos objetos. ${ }^{2}$

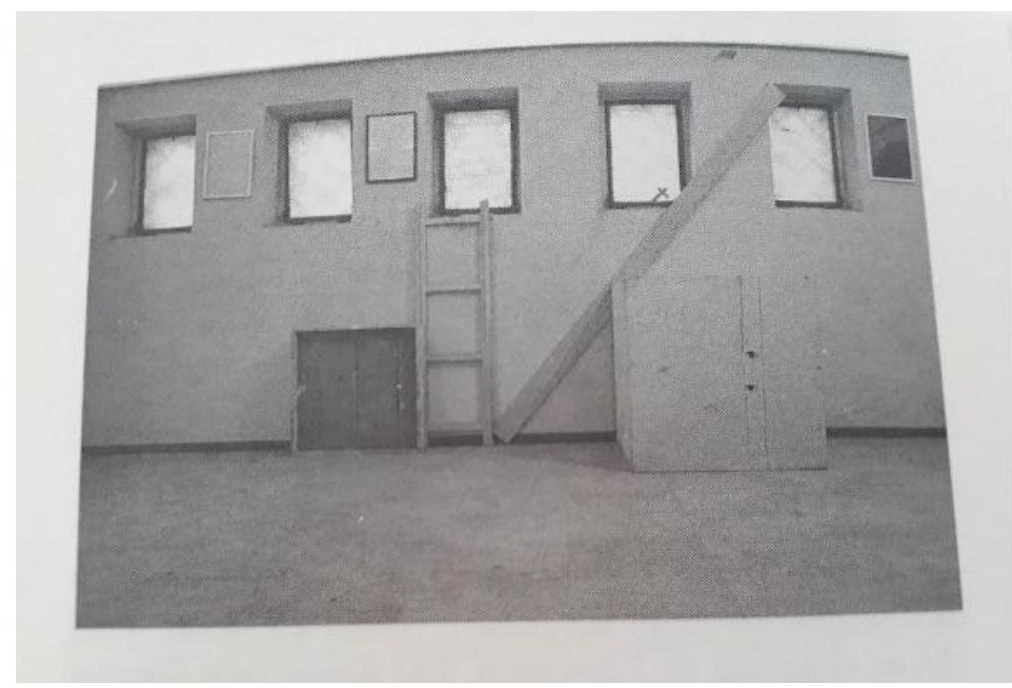

Fig. 1 - Depósito escolhido por Parmiggiani na Galleria Civica di Modena.

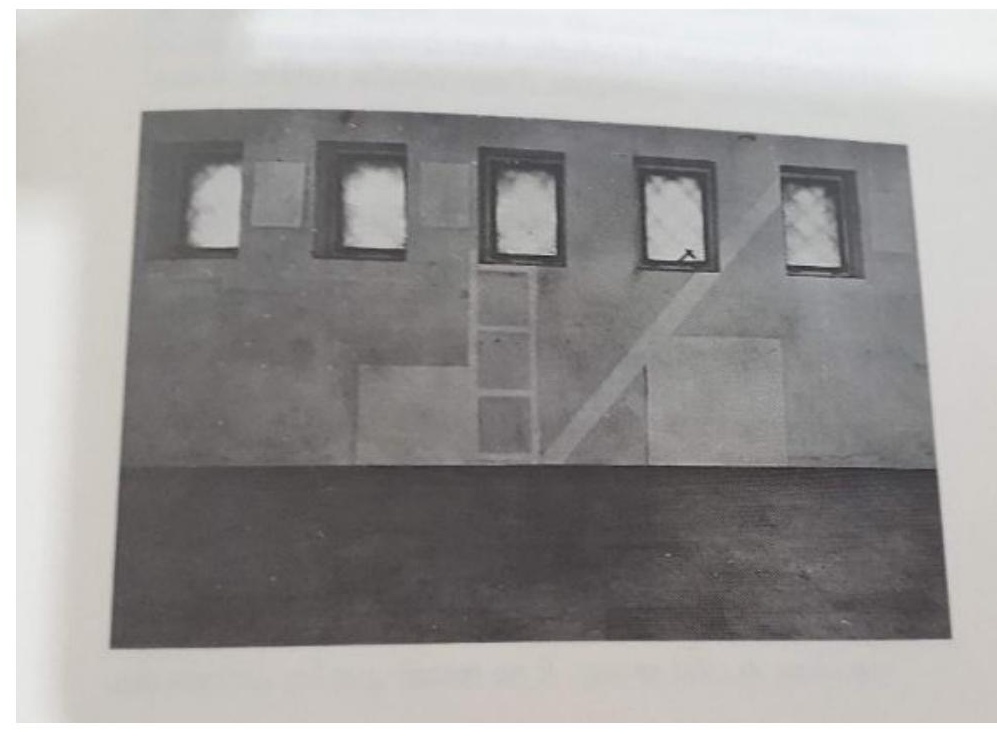

Fig. 2 - Claudio Parmiggiani, obra da série Delocazione. 
Em outro trabalho, Labirinto di Vetri Rotti[1995], Parmiggiani prepara em uma grande sala do Le Fresnoy [centro de formação artística e audiovisual na França] um labirinto com placas de vidro espalhadas pelo espaço. Vestindo uma roupa protetora, capacete e luvas, o artista caminha pelo espaço e quebra, com a ajuda de um martelo, as placas de vidro. O procedimento dura cerca de vinte minutos e, ao final, as placas estão em diversos tamanhos, além de inúmeros cacos estarem espalhados pelo chão [Fig. 3]. O espaço labiríntico se torna, então, impenetrável. ${ }^{3}$
Jean-Luc Nancy comenta brevemente esse trabaIho ao final de sua conferência El arte hoy, publicada no livro de mesmo título [2014]4, em que ele desdobra questões sobre a arte contemporânea, preferindo recusar essa nomenclatura e falar em "arte hoje". Como último de seus exemplos, Nancy cita Labirinto di Vetri Rotti e afirma que a obra apresenta, simultaneamente, uma transparência e uma impenetrabilidade, tensionando assim suas experiências, a princípio, contraditórias ou, ao menos, heterogêneas. O gesto de destruição do vidro realizado por Parmiggiani seria também um gesto de destruição da transparência.

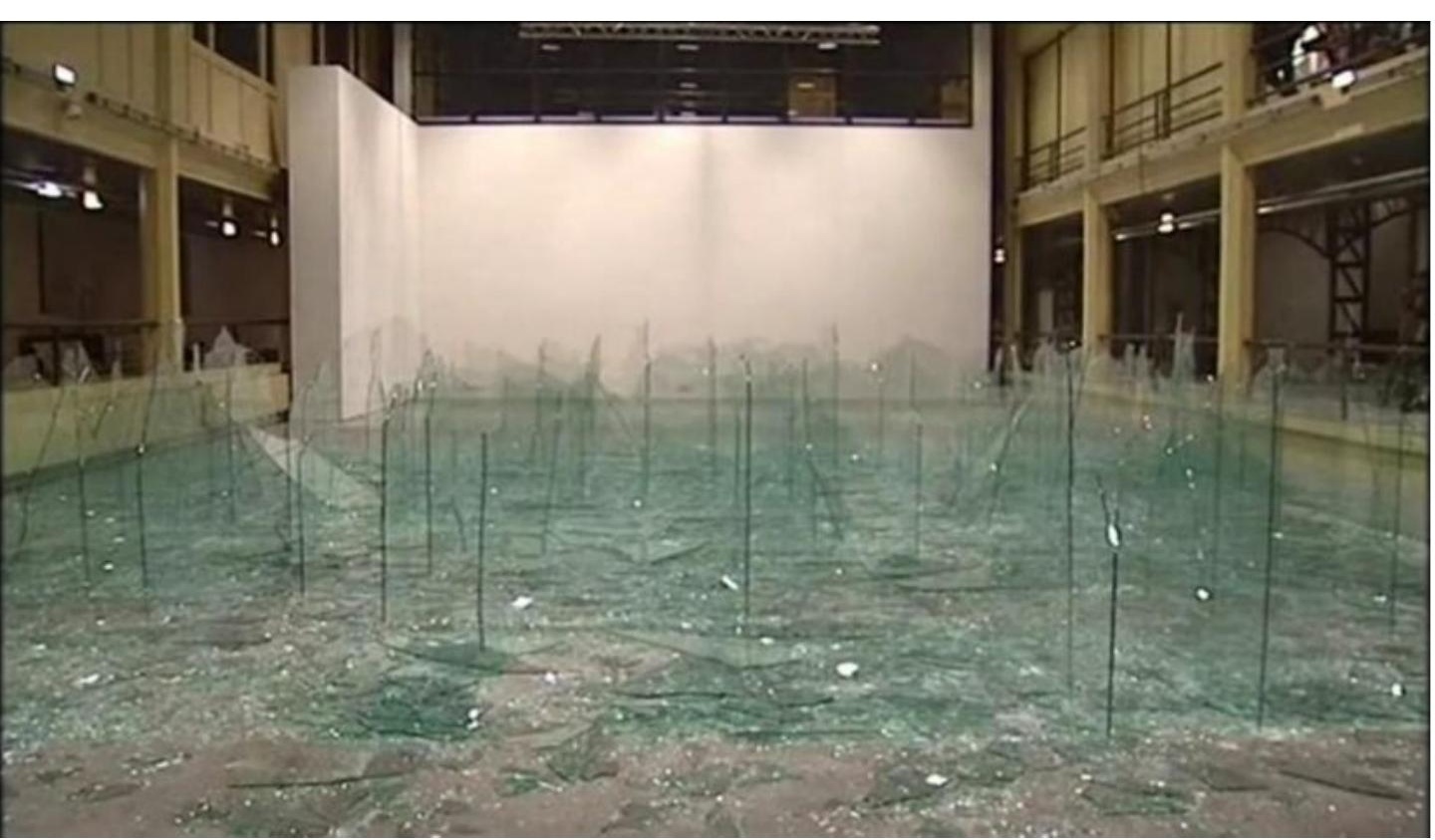

Fig. 3 - Claudio Parmiggiani, Labirinto di Vetri Rotti, 1995, Le Fresnoy.
Nancy afirma que a pintura clássica tinha grande preocupação em captar a transparência do vidro [muitas são as pinturas em que se veem vidros, garrafas, cristais] e que essa preocupação revela também o desejo de colocar luz sobre as coisas, ou seja, de torná-las claras, transparentes, e tornar também os signos claros. Nancy cita, inclusive, a expressão 
bíblica fiat lux [faça-se a luz], relativa à criação do mundo. Podemos, talvez, pensar nessa expressão, relacionada ao ato de criação, em contraposição ao gesto destrutivo de Parmiggiani [ainda que o artista crie, primeiro, o espaço, para depois destruí- lo parcialmente, pois restam apenas cacos]. E ao restarem cacos, uma certa opacidade se constitui, em relação à própria impenetrabilidade do espaço. Nancy afirma:

Eu diria que esta obra ilustra que existe um gesto que, neste caso, é um gesto de quebra, portanto um gesto violento, um gesto de destruição e também a destruição, justamente, da transparência, do sentido que se comunica, e, ao mesmo tempo, um signo sem significação, além da obra e além da destruição, mas não em direção a uma nova construção, pois não é um objetivo social, político ou ético. [NANCY, 2014, p. 35]

Nesse caso, o gesto do artista é, segundo Nancy, repetir a transparência até o infinito, por meio das camadas de vidro que se sobrepõem, mas também destruir a transparência. Parmiggiani quebra os vidros e, assim, impede o acesso ao labirinto de transparência, ao mesmo tempo em que impede a construção de um sentido imediato da obra.

A respeito de Labirinto di Vetri Rotti, Didi-Huberman faz a seguinte observação, em Génie Du No-Lieu: Air, Poussière, Empreinte, Hantise: "O resultado era um campo de ruínas transparentes, um lugar de devastação, de onde surgiam ainda os restos lascados, os traços no solo do labirinto. A obra se assemelhava exatamente a um espaço soprado por uma explosão" [DIDI-HUBERMAN, 2001, p. 38].

Ou seja, esses trabalhos artísticos citados até aqui se constituem a partir de uma destruição, ou meIhor, de vários modos de destruição: as obras da série Delocazione, a partir da queima dos pneus, e Labirinto di Vetri Rotti, a partir da quebra das placas de vidro. E, de outro modo, os trabalhos de Giacometti, a partir do apagamento ou do desfazimento das figuras, do desfiar do gesso ou do escavar do bronze. Por mais de uma escolha processual relacionada a operações de destruição, esses trabalhos artísticos se elaboram restos, vestígios. No primeiro caso, os vestígios são as impressões deixadas pelos objetos, nas superfícies, pela ação do tempo, da poeira ou das cinzas, e também pelo gesto do artista de deslocá-los do lugar em que estavam apoiados ou colocados. No segundo caso, o que resta são os destroços das placas de vidro quebradas, cacos espalhados pelo espaço. Nos dois casos, há a instauração de um lugar, a elaboração de um espaço outro a partir de uma destruição. Já no caso dos trabalhos de Giacometti [e não abordo aqui nenhuma obra em particular, mas tento pensar em determinados procedimentos repetidos pelo artista], o desfazer insistente deixa, muitas vezes, suas figuras, suas esculturas, por um fio [Fig. 4]. 


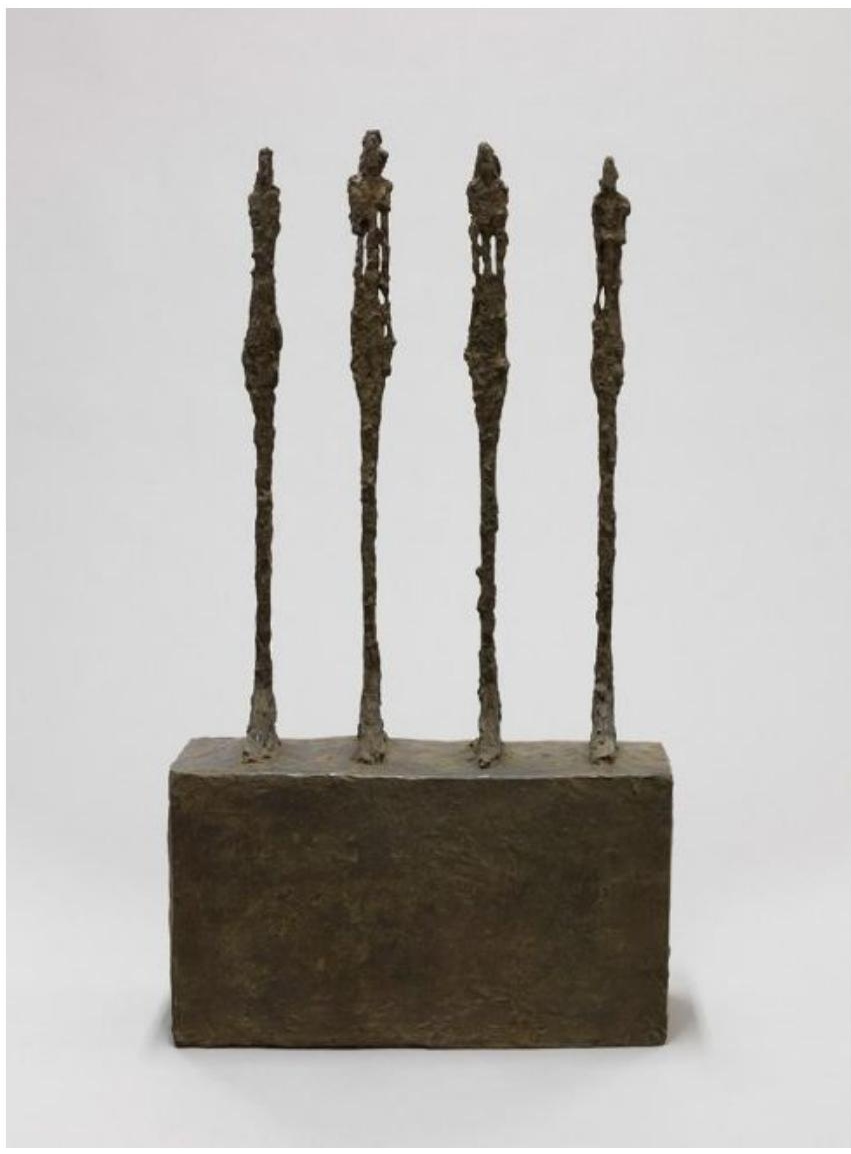

Fig. 4 - Alberto Giacometti, Quatre femmes sur socle, 1950, escultura em bronze, 76 × 41,3 x 16,4cm., coleção Fundação Giacometti, Paris.

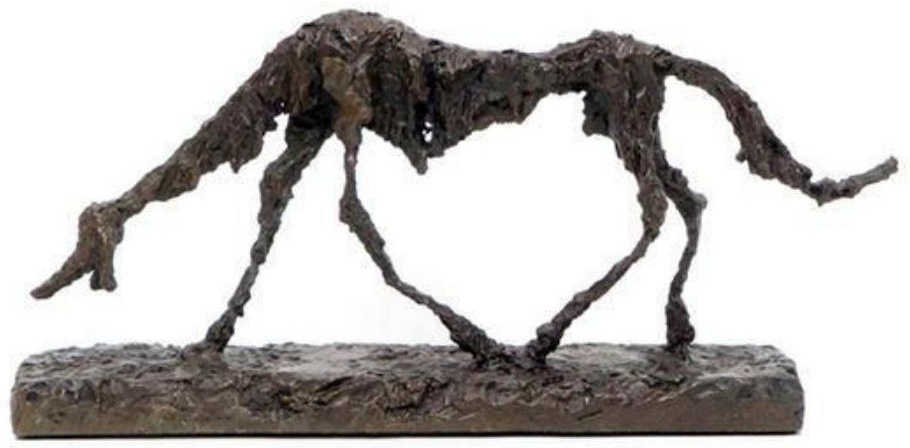

Fig. 5 - Alberto Giacometti, Le chien, 1951, escultura em bronze, 44.2 × 96.8 × 15.7 cm., Guggenhein Museum, Nova York. 
Na escultura acima, por exemplo, as quatro muIheres aparecem tão alongadas, tão afiladas, que suas formas quase desaparecem. O trabalho de Giacometti com o bronze é de quase destruição do material e o bronze passa a conservar as marcas dos dedos do artista, como podemos ver em Quatre femmes sur socle [Quatro mulheres sobre o pedestal]: há nas figuras uma rugosidade, relevos oriundos do manusear do bronze por Giacometti. Um manusear que faz e, ao mesmo tempo, desfaz as figuras trabalhadas pelo artista.

A escultura Le chien [O cão] também nos mostra o trabalho de Giacometti com o bronze. As marcas no bronze são quase as impressões dos dedos do artista na matéria, são vestígios das inúmeras tentativas de modelar o bronze e dos desfazimentos operados por Giacometti. É este fazer desfazendo que afina as figuras, de forma a fazer com que elas apareçam na iminência do desaparecimento.

James Lord percebeu esse procedimento e transcreve um trecho do diálogo que teve com Giacometti, enquanto posava para um retrato:

- Agora você vai destruir tudo, suponho, eu disse quando começamos a trabalhar.

-Exatamente, respondeu.

E foi isso, obviamente, que começou a fazer [...]

-Estou demolindo-o alegremente, observou algum tempo depois. [LORD, 1998, p. 123-124]
Essa demolição era, nesse caso, feita no desenho, no retrato de Lord, mas ocorria também na escavação na matéria. Era como se Giacometti procurasse no próprio material [gesso, bronze, tela, papel] as suas figuras. Como se essas figuras já estivessem no material e Giacometti precisasse manipulá-lo intensamente para que dele só restassem vestígios, e para que as figuras, enfim, se revelassem.

Para pensar um pouco mais detidamente sobre a noção de vestígio, a reflexão de Jean-Luc Nancy presente na conferência $O$ Vestigio da Arté torna-se importante para a análise que aqui se pretende desenvolver. Ao tematizar as discussões sobre arte contemporânea e sobre os diagnósticos do fim da arte, Nancy afirma:

○ que resta da arte? Talvez apenas um vestígio. É pelo menos o que se ouve atualmente, uma vez mais. Propondo como título desta conferência "O Vestígio da Arte", tenho primeiramente em vista, simplesmente, o seguinte: supondo-se que não reste com efeito senão um vestígio - ao mesmo tempo um rastro evanescente e um fragmento quase inapreensível -, isso mesmo poderia ser apropriado para nos colocar na pista da própria arte, ou pelo menos de alguma coisa que the seria essencial, se pudermos levantar a hipótese de que o que resta é também o que resiste mais [NANCY, 2012, p. 289]

Nessa conferência, Nancy propõe pensar a arte não a partir de uma essência imutável, pois a arte seria sempre radicalmente

AMORIM, Daidrê Thomas de. Cinzas, cacos e rastros: apontamentos sobre a noção de vestígio. 
outra, já que responde a cada vez a um novo mundo. Como alternativa a essa noção de essência, o filósofo propõe pensar a arte como vestígio. Na verdade, ele opta por uma proposição paradoxal. Diz ele: "teremos de nos perguntar se essa alguma coisa de essencial não seria, por sua vez, da ordem do vestígio [...]" [NANCY, 2012, p. 289]. Ou seja, Nancy propõe pensar uma essência vestigial da arte, já que o que resiste é o que sobrevive às transformações e destruições.

Mas, ao final de sua conferência, Nancy afirma que é preciso renunciar a nomear o ser do vestígio: "o vestigial não é uma essência - e é provavelmente isso mesmo que nos põem doravante no rastro da 'essência da arte'" [NANCY, 2012, p. 304]. Portanto, se no início de seu texto Nancy propõe, provocativamente, pensar uma essência vestigial da arte, mais adiante ele distingue o vestígio da essência. Segundo ele, a arte não é apresentação da Ideia, a arte apresenta a "moção, a vinda, a passagem, o em-ida de toda vinda-em-presença" [NANCY, 2012, p. 304].

Ainda segundo Nancy, a arte tem uma história. A história e a passagem conduzem ao vestígio. Diz Nancy: "Anteciparei aqui apenas uma conclusão: a arte tem uma história, e ela é talvez radicalmente história, isto é, não progresso, mas passagem, sucessão, aparição, desaparecimento, acontecimento" [NANCY, 2012, p. 294].
A arte seria, portanto, o que resta, e o que resta de si mesma. $\bigcirc$ que resta é aquilo que resiste, o que fica de uma destruição, o que sobrevive de alguma forma ao desaparecimento ou apagamento. Se há vestígio, é porque algo permanece, mesmo que ínfimo. Nesse sentido, pensar a arte, para Nancy, não seria pensar o seu fim, a sua morte, mas os seus vários fins, suas mortes constantes e sobrevivências. Uma finição infinita7, um acabamento sem fim, para recorrer à expressão mencionada por Nancy. E pensar também nos seus rastros e restos. Para Nancy, o vestígio é o que resta de uma retirada.

No caso de Delocazione, o que fica nas paredes e superfícies é aquilo que resistiu ao tempo [no caso da poeira], aquilo que restou da queima e da retirada, da subtração dos objetos de seus lugares: a impressão, a marca nas paredes. A noção de impressão, inclusive, está intrinsecamente ligada à de vestígio. Nancy ressalta que a palavra latina vestigium designa a sola ou a planta do pé, uma pegada de um passo, e que para que se produza uma pegada há necessidade do contato do pé com o chão e da perda desse contato. Portanto, uma pegada é, simultaneamente, a marca de uma presença e de uma ausência, já que registra uma passagem. Assim, o vestígio está ligado a uma temporalidade, a uma passagem [do tempo e de um corpo], e também a uma intensa materialidade, já 
que só se produz por meio do contato de um corpo com uma superfície, com uma matéria; do contato de uma matéria com outra.

De certo modo, a noção de vestígio também pode ser relacionada à noção de imago para os romanos, mencionada por Didi-Huberman em seu livro Diante do Tempo - História da Arte e Anacronismo das Imagens. O autor lembra aí a noção de imagem [imago] para Plínio, o Velho, no século I d.C. Didi-Huberman descreve a produção das máscaras mortuárias, que eram feitas por meio do contato do gesso com o rosto do morto. A partir desse molde negativo se produziam máscaras de cera. Tais máscaras tinham extrema semelhança com o morto e era esta semelhança que prezava Plínio para as imagens.

A imago não é, portanto, uma imitação no sentido clássico do termo; ela não é factícia e não requer nenhuma idea, nenhum talento, nenhuma magia artística. Ao contrário, ela é uma imagem-matriz produzida por aderência, por contato direto da matéria [o gesso] com a matéria [do rosto]. [DIDI-HUBERMAN, 2015, p. 81]

Essas máscaras, assim como as pegadas [mencionadas por Nancy], exigiam o contato, uma presença material e, ao mesmo tempo, a perda do contato, a separação [o deslocamento] do molde de gesso do rosto do morto. As máscaras mortuárias registravam uma ausência [a ausência do morto, e o próprio morto como ausência, ausência de vida]. No texto do livro XXXV [um dos trinta e sete livros que compõem a História natural], Plínio diz que "tinha-se, assim, imagens [imagines] para fazer o cortejo fúnebre da família e, sempre que alguém morria, toda a multidão de parentes desaparecidos estava presente" [Apud DIDI-HUBERMAN, 2015, p. 80]. Contudo, enquanto as máscaras são individuais e, portanto, identificam um morto específico, as pegadas permitem descobrir a passagem de alguém, mas não necessariamente quem é este alguém.

\section{O procedimento de impressão só se dá por meio} de um processo de subtração: algo se retira, ou é retirado, para que sua marca seja deixada. O rosto do morto só se imprime no gesso quando é afastado do molde, do mesmo modo, o negativo do molde só deixa sua marca nas máscaras de cera quando o negativo é deslocado, quando perde seu contato direto com a cera. Assim também no caso das impressões produzidas por Parmiggiani por meio de poeira e cinzas: só se pode visualizar as marcas dos objetos nas superfícies a partir de seu deslocamento, de seu recuo do espaço inicial. O que vemos nas paredes, após o deslocamento dos objetos, é um negativo de suas formas.

Procedimento similar é utilizado pelo artista brasileiro Carlos Vergara ${ }^{8}$, tanto em sua obra Sudário [2003-2019] quanto em Prospectiva[2019]. Sudário é uma série de 200 monotipias` realizadas em lenços 
nos locais que o artista percorreu em busca do que

ele chama de sinais do sagrado: Sete Povos das

Missões [Rio Grande do Sul], Istambul e Capadócia, Pompeia [Itália], Serra da Bodoquena [Mato Grosso do Sul], Caminho de Santiago de Compostela [Espanha], Cazaquistão e Rio Douro [Portugal]. Prospectiva é constituída por três pinturas em telas de grande formato $[5,40 \mathrm{~m} \times 5,40 \mathrm{~m}]$ a partir de monotipias realizadas no Cais do Valongo e nos trilhos do bonde em Santa Teresa, no Rio de Janeiro.

Nesses trabalhos, está implicado um duplo deslocamento: o deslocamento do artista pelo mundo, suas viagens, e o deslocamento dos lenços e telas nos espaços que Vergara busca imprimir. Os "sinais do sagrado" encontrados pelo artista são rapidamente marcados nos tecidos que ele carrega consigo, apenas com a ajuda de carvão, que ele aplica nas superfícies. Algumas vezes, ficam impressos nos tecidos guimbas de cigarro, pedaços de madeira, folhas e outros objetos pertencentes aos locais visitados, que entraram em conta-

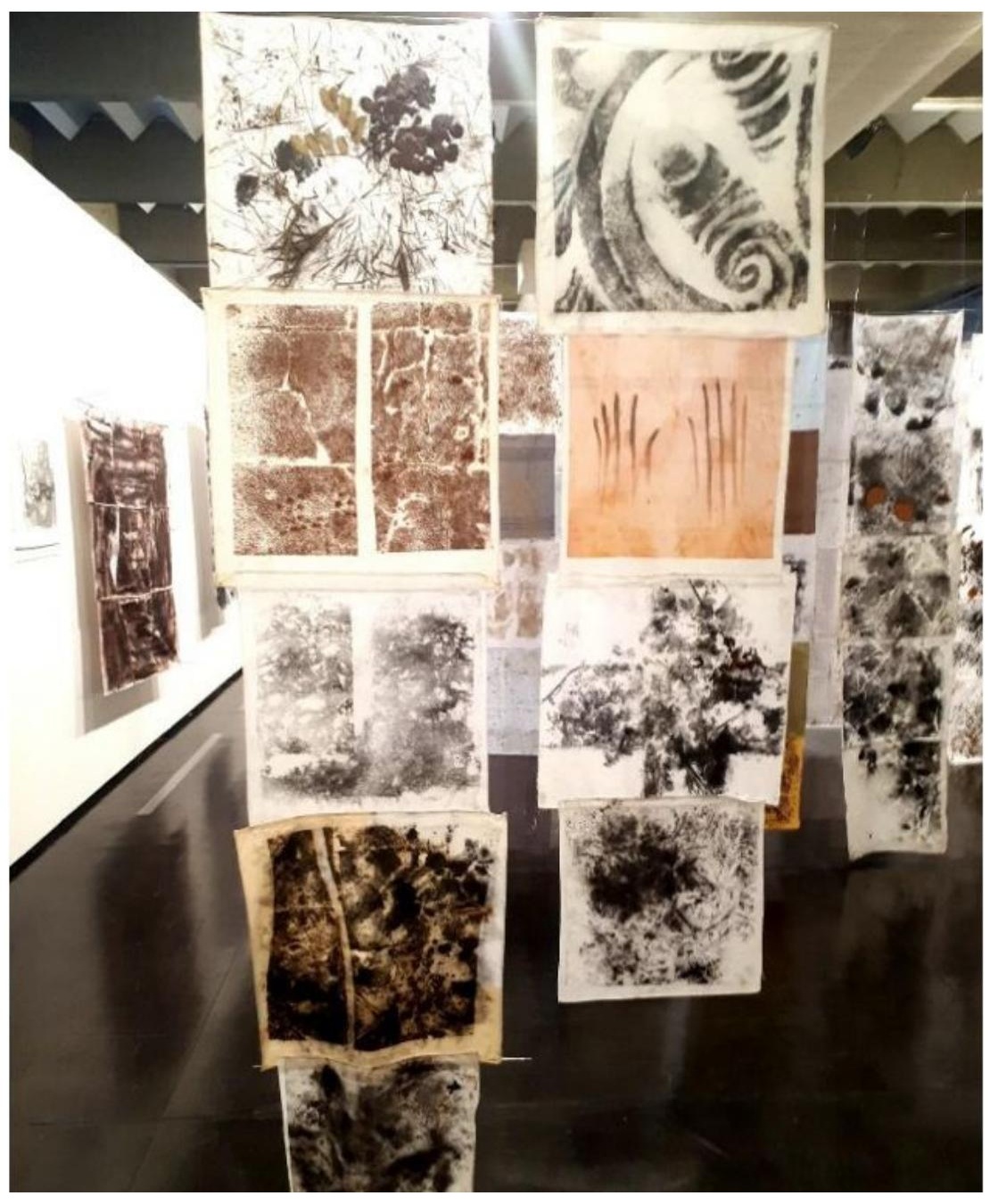

Fig. 6 - Carlos Vergara, Exposição Sudário to com os tecidos, acoplando-se neles [Fig. 6]. 
Se pensarmos sobre esses trabalhos de Vergara e sobre algumas das obras da série Delocazione, de Parmiggiani, podemos perceber certas afinidades. Ambos os artistas realizam suas obras por meio do toque e da perda de contato. Não há, em nenhum dos casos, uma tentativa de virtuosismo artístico ou de representação dos objetos. Ainda assim, justamente pelos procedimentos de impressão envolvidos, as obras adquirem traços e contornos dos objetos com os quais tiveram contato: trilhos, árvores [no caso de Vergara] ou livros [no caso de Parmiggiani], entre outros.

Essas formas, impressas nos materiais e superfícies, entretanto, são genéricas, digamos assim: reconhecemos que se trata de um livro, por exemplo, por seus contornos, mas não há ali detalhes que possam identificar a que livro se refere. Considerando o princípio da causalidade e a fidelidade em relação ao referente, geralmente associadas à representação [ou a uma determinada noção de representação, mais convencional e mais fixa], Nancy estabelece uma distinção entre imagem e vestígio. Para diferenciar essas duas noções, no contexto específico de sua reflexão, Nancy remete à teologia cristã. Para os teólogos, segundo o autor, o homem é considerado imago Dei[imagem e semelhança de Deus], enquanto no restante da criação, Deus se apresenta apenas de forma vestigial.
Os teólogos puseram em ação a diferença da imagem e do vestígio a fim de distinguir entre a marca de Deus na criatura razoável, no homem imago Dei, e outro modo dessa marca, no resto da criação. Esse outro modo, o modo vestigial, caracteriza-se pelo seguinte [łomo de empréstimo a análise de São Tomás de Aquino]: o vestígio é um efeito que "representa apenas a causalidade de sua causa, mas não a sua forma". São Tomás de Aquino dá como exemplo a fumaça, cuja causa é o fogo. [...] "O vestígio mostra que houve movimento de algum passante, mas não de qual". O vestígio não identifica sua causa ou seu modelo, diferentemente [é ainda o exemplo de São Tomás de Aquino] da "estátua de Mercúrio, que representa Mercúrio", e que é uma imagem. [É preciso aqui lembrar que, em conceitos aristotélicos, o modelo é também uma causa, a causa "formal".] [NANCY, 2012, p. 301]

Assim, o vestígio, segundo Nancy, lida com o princípio da causalidade de um modo específico. Ele não exibe a forma de sua causa, mas apenas seu movimento, sua passagem. A causalidade, no vestígio, é nebulosa, indefinida, não é totalmente identificável. A noção de vestígio desloca a arte dos habituais eixos do modelo ou referente: aquilo que produz vestígios não deixa neles sua forma, por isso não se trata propriamente de representação [não se trata da reapresentação de um modelo prévio, na qual a forma do modelo permanece na obra]. Na fumaça vestigial, diz Nancy, não há a forma do fogo. A fumaça não conserva do fogo sua forma, mas 
apenas sua consumação [NANCY, 2012, p. 301302]. A fumaça indica a ausência do fogo.

Na concepção da teologia cristã, podemos perceber, de algum modo, uma hierarquia: o homem como imagem e semelhança de Deus, enquanto o restante da criação é apenas o seu vestígio. Ao afirmar que o que resta é aquilo que mais resiste, Nancy desfaz essa hierarquia, ou ao menos a problematiza.

Mesmo quando se trata de um vestígio produzido "de forma passiva pelo tempo", como Didi-Huberman afirma serem os vestígios produzidos pela poeira, não podemos negar que há aí uma ação implicada: há um trabalho do tempo, ainda que não haja o trabalho do artista. Entretanto, talvez seja possível distinguir ao menos dois modos de vestígios, dois modos de restar: aqueles que, por meio do contato, adquirem alguma similaridade com aquilo a que aderiram momentaneamente [uma semelhança por contato ${ }^{10}$ e não por imitação] e aqueles que se constituem como restos ou fragmentos de algo que desapareceu ou foi destruído.

Para exemplificar, pensemos na diferença entre os trabalhos de Parmiggiani aqui citados. Nas obras pertencentes a série Delocazione, os vestígios são as impressões deixadas no espaço, nas superfícies, as marcas que configuram os contornos dos objetos após seu contato com determinada matéria [cinzas ou poeira] e seu posterior deslocamento. Já em Labirinto di Vetri Rotti, os vestígios são os cacos, os fragmentos de vidro, restos da destruição provocada pelo artista.

Nos dois casos, as dimensões de tempo e de lugar seguem sendo fundamentais na noção de vestígio. Ao deslocar os objetos de seu lugar ou posição iniciais, ou quebrar os vidros, Parmiggiani constrói outro lugar e outra temporalidade.

Em seu texto sobre a noção de vestígio, Nancy afirma que "um lugar no sentido forte da palavra é sempre o vestígio de um passo" [NANCY, 2012 , p. 304]. O vestígio é, para o autor, o resto de um passo, mas o próprio passo jamais é algo além do que sua própria passagem. Portanto, para Nancy, o vestígio é a própria operação do passo, sem ser sua obra. Assim, o lugar dá a ver o passo. Isto ocorre porque a instauração do lugar é precedida por uma retirada, pelo deslocamento de algo que antes ali estava. Assim como para a configuração da pegada é necessária a ausência do pé - o deslocamento, o passo -, assim também um lugar pode se constituir a partir da ausência, de um trabalho de retirada e de deslocamento, ou mesmo a partir de uma inacessibilidade. ${ }^{11}$ 
Nesse sentido, é possível pensar nas obras de Alberto Giacometti retomando a citação de Didi-Huberman que está na epígrafe deste artigo. Giacometti agia, trabalhava sobre o material de que dispunha, de forma quase destrutiva. Quando desenhava, muitas vezes rasgava as folhas com a força do lápis; quando esculpia, deixava no bronze as marcas de seus dedos e no gesso fiapos aparentes; já quando pintava, seus quadros eram constantemente apagados e raspados. Suas obras conservavam, portanto, as marcas de suas hesitações e destruições.

Em um retrato que Giacometti fez de sua esposa e principal modelo, Annette[1961], a figura da mulher quase desa-

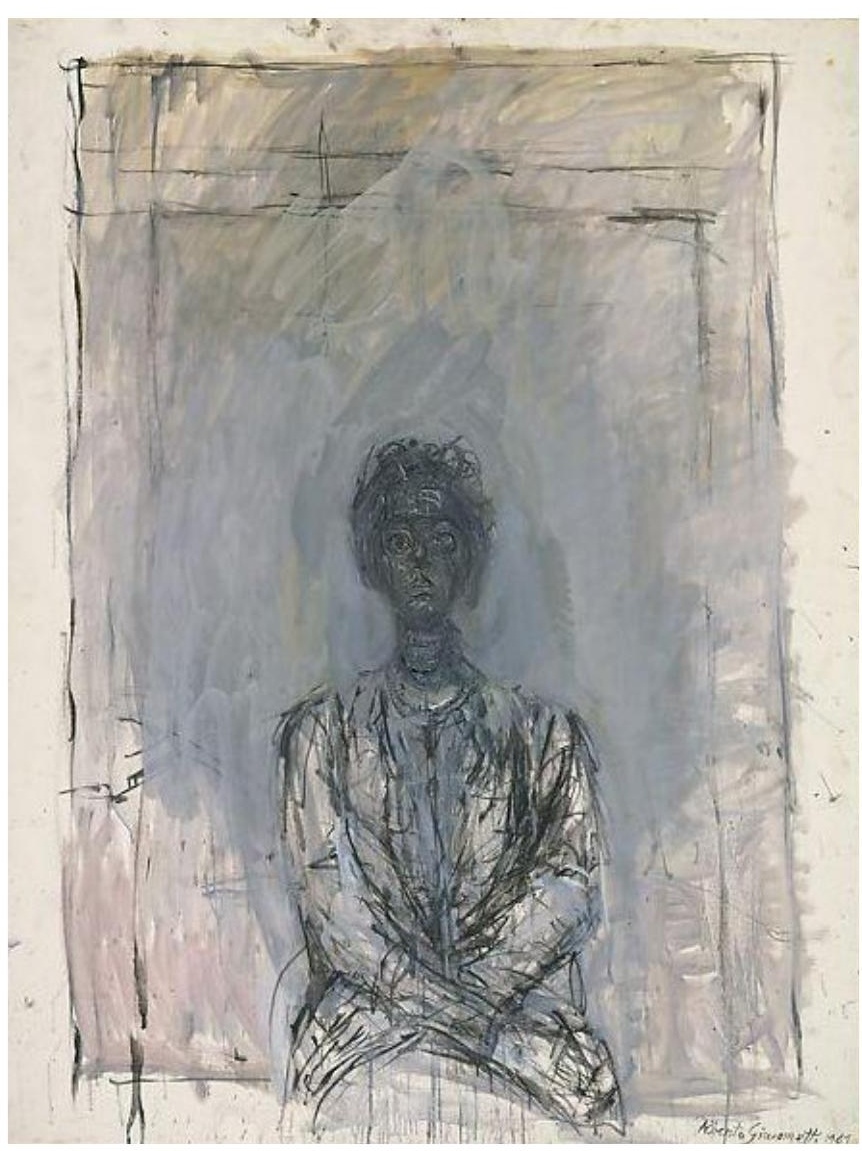

Fig. 7 - Alberto Giacometti, Annette, 1961, óleo sobre tela, 116,2× 89,5 cm., The Metropolitan Museum of Art, Coleção Jacques e Natasha Gelman, Nova York.
Esse retrato foi retrabalhado, inclusive, após já ter sido exibido uma primeira vez em Paris. Giacometti considerou que precisava refazer o nariz de Annette, mas acabou por refazer todo o rosto e retrabalhar também o fundo do quadro. A cabeça proporcionalmente menor e mais escura que o corpo é resultado das tentativas de Giacometti de retratar o que via e de dar profundidade ao quadro. Por essa razão o artista gostava de pintar com a luminosidade mais escassa, pois assim percebia quais partes da cabeça possuíam mais relevo e recebiam mais luz.

Jean Genet, no livro 0 Ateliê de Giacometti, transcreve um diálogo parece do quadro após as inúmeras rasuras feitas pelo artista [Fig. 7].

que teve com o artista. Nele, Genet diz que não eram as esculturas de Giacometti que ganhavam quando 
feitas em bronze, mas o bronze é que ganhava ao ser matéria de suas estátuas:

Essa conversa permite-nos inferir, dentre outras possibilidades de compreensão, que o desgaste do bronze produzido por Giacometti é o que the

ELE: Você as viu em gesso... Lembra-se delas, em gesso?

EU: Sim.

ELE: Acha que perdem, em bronze?

EU: Não. De maneira nenhuma.

ELE: Acha que ganham?

Hesito aqui mais uma vez em proferir a frase que expressará melhor o meu sentimento:

EU: Você vai zombar de mim de novo, mas a impressão que tenho é curiosa. Não diria que elas ganham, e sim o bronze que ganhou. Pela primeira vez em sua vida, o bronze acaba de ganhar. Suas mulheres são uma vitória do bronze. Sobre ele próprio, talvez.

ELE: É assim que tinha que ser. [GENET, 2000, p. 16-17]

permite essa vitória. O que resta do bronze após o trabalho destrutivo de Giacometti seria, na visão de Genet, o que de mais forte havia no bronze, percepção que está, de certo modo, em consonância com a de Nancy, quando ele considera que o vestígio é o que mais resiste, por isso, é o que resta.

Em outro trecho do livro sobre Giacometti, Genet afirma:
Suas estátuas parecem pertencer a uma era defunta, descobertas depois que o tempo e a noite - que as trabalharam com inteligência - as corroeram para lhes dar esse ar, ao mesmo tempo doce e duro, de eternidade que passa. Ou, melhor ainda, saíram do forno, resíduos de um cozimento terrível: apagadas as chamas, isso é o que restaria. [GENET, 2000, p. 44]

Genet menciona a materialidade das estátuas de Giacometti como, aparentemente, resultantes de um cozimento, saídas do fogo, das chamas. Mas também como oriundas de uma outra temporalidade, ao mesmo tempo eterna e passageira. Desse modo, podemos entender que o escritor via as obras de Giacometti como vestígios, sobrevivências: sobreviveram à destruição pelo fogo, sobreviveram ao tempo, à morte: "suas estátuas parecem pertencer a uma era defunta" e foram trabalhadas pelo tempo e pela noite. Suas estátuas não apenas conservam os vestígios das hesitações do artista, como poderiam ser também consideradas, elas próprias, como vestígios, aquilo que restou, que resistiu aos procedimentos destrutivos, aos desfazimentos. Tanto a ideia de corrosão quanto a de cozimento e chamas, mencionadas por Genet, aludem a uma destruição. 
De algum modo, esta concepção da forma como vestígio da matéria está presente também nas reflexões do filósofo italiano Giorgio Agamben. No ensaio Do livro à tela. O antes e o depois do livro, publicado no livro O fogo e o relato: Ensaios sobre criação, escrita, arte e livros [2018], o autor destaca e analisa aquilo que precede e que sucede uma obra de arte, considerada e valorizada geralmente como algo finalizado, pronto. Agamben cita, entre outros exemplos, o livro Um retrato de Giacometti, em que James Lord afirma que Giacometti costumava dizer que "um quadro nunca é terminado, é simplesmente abandonado" [AGAMBEN, 2018, p. 117].

O que costumamos entender como obra finalizada, acabada é, na verdade, segundo Agamben, apenas um momento de um "processo criativo potencialmente infinito" que se estende tanto em direção ao passado, incluindo todos os rascunhos, esboços, fragmentos, hesitações e tentativas que o artista realizou, quanto em direção ao futuro, abarcando a recepção e suas históricas transformações. O filósofo ressalta que a interrupção da obra de arte em determinado ponto é apenas contingente.

A cesura que põe fim à redação da obra não the confere um estatuto privilegiado de completude: significa somente que se diz estar terminada a obra quando, mediante a interrupção ou o abandono, se constitui como que um fragmento de um processo criativo potencialmente infinito, em relação ao qual a obra, chamada de acaba- da, distingue-se da inacabada apenas acidentalmente. [AGAMBEN, 2018, p. 117]

\section{Enquanto Agamben compreende o processo cri-} ativo como potencialmente infinito, no qual a obra acabada é apenas um momento de interrupção ou abandono, Nancy percebe um "acabamento sem fim" na própria história da arte:

Mas esse acabamento sem fim - ou esse acabamento acabado, se tentarmos entender isso como uma finalização que se limita ao que ele é, mas que, por isso mesmo, abre a possibilidade de um outro acabamento, e que é, portanto, igualmente acabamento infinito -, esse modo paradoxal da per-feição é provavelmente o que toda nossa tradição exige e evita ao mesmo tempo pensar. [...] Assim, essa tradição designa como que um limite, como um fim no sentido banal, e bem depressa como uma morte, o que poderia ser na verdade a suspensão de uma forma, o instantâneo de um gesto, a síncope de uma aparição - e, portanto, também, a cada vez, de um desaparecimento. Somos capazes de pensar isso? Ou seja, como podem adivinhar, de pensar o vestígio. [NANCY, 2012, p. 294-295]

Assim, podemos pensar que essa infinalização, estes infinitos desaparecimentos e aparecimentos, são pertinentes à arte, tanto historicamente [o que faz com que Nancy não partilhe da ideia de uma morte da arte] quanto no que se refere aos seus procedimentos e processos, e é neste sentido que a arte se relaciona à noção de vestígio. 
No final do ensaio Do livro à tela. O antes e o depois do livro, Agamben afirma: "Gostaria de propor, neste ponto, uma definição mínima do pensamento, que me parece particularmente pertinente. Pensar significa lembrar-se da página em branco enquanto se escreve ou se lê. Pensar - mas também lersignifica lembrar-se da matéria" [AGAMBEN, 2018, p. 136]. E, mais adiante, Agamben observa que as formas nada mais são do que vestígio do sem forma [AGAMBEN, 2018, p. 136].

Portanto, o trabalho do artista é, de certa maneira, encontrar a forma na matéria, encontrar na matéria o seu vestígio. Talvez fosse algo similar que Giacometti tivesse compreendido quando, ao retratar Lord, "continuou a trabalhar, servindo-se do pincel grande" [LORD, 1998, p. 105] e afirmou:

- $\bigcirc$ que estou fazendo é um trabalho negativo, disse. É preciso fazer desfazendo. Tudo está desaparecendo mais uma vez. É preciso ousar, dar a pincelada que faz tudo desaparecer. [LORD, 1998, p. 105]
NOTAS

1 James Lord foi um escritor e crítico de arte norte-americano nascido em 1922 e falecido em 2009, em Paris. Foi retratado por diversos artistas, dentre eles Picasso, Lucien Freud, Cartier-Bresson e Dora Maar. Posou para Alberto Giacometti por dezoito sessões em 1964 e, durante esse período, realizou diversas anotações, que resultaram em um livro que escreveu sobre o artista, Um Retrato de Giacometti (LORD, 1998). Ou seja, enquanto era retratado por Giacometti, tomou notas de diálogos e reflexões para compor, por meio da escrita, um retrato do artista.

2 A partir dessa perspectiva e escolha de procedimentos, Parmiggiani realizou vários outros trabalhos da série Delocazione, que se constitui como uma longa série de experimentações com as impressões, os vestígios deixados pelas cinzas, pela obra do fogo. Um filme foi realizado em 2001 por Carine Bobin, Pascal Convert, Martine Convert e Laurent Tarbouriech, a partir de uma das obras da série.

3 Filme realizado em 1995 por Carine Bobin, Pascal Convert, Martine Convert e Laurent Tarbouriech.

4 Cito aqui a tradução para o espanhol dessa conferência, escrita originalmente em francês. Conferência essa que está incluída em um livro publicado em Buenos Aires, e que reúne ensaios de Nancy traduzidos por Carlos Pérez López e Daniel Álvaro.

5 Diría que essa obra ilustra que "hay un gesto que, en este caso, es un gesto de romper, por ende un gesto violento, un gesto de destruicción y tambíen la destruicción, justamente, de la transparencia, del sentido que se comunica, y al mismo tempo un signo sin significación, más allá de la obra y más allá de la destruicción, pero no hacia una nueva construcción, pues no es un propósito social, político o ético." (NANCY, 2014.) 
6 Conferência pronunciada no Jeu de Paume e publicada pela primeira vez em L'Art contemporain en question, Paris: Jeu de Paume, 1994. A versão utilizada neste artigo foi traduzida por Mary Amazonas Leite de Barros e publicada no livro Fragmentos de uma teoria da arte, organizado por Stéphane Huchet em 2012.

7 "O vestígio é o resto de um passo. Não é sua imagem, pois o próprio passo não consiste em nada mais que seu próprio vestígio. Desde que ele é feito, ele é passado. Ou melhor, ele não é jamais, enquanto passo, simplesmente "feito" e depositado em alguma parte. Se se pode assim dizer, o vestígio é seu toque, ou sua operação, sem ser sua obra. Ou então, nos termos que eu empregava há pouco, ele seria sua finição infinita lou a infinition) e não a perfeição acabada. Não há presença do passo, mas ele é por sua vez apenas vinda em presença." (NANCY, 2012, p. 304)

8 Nascido em Santa Maria, no Rio Grande do Sul, em 1941, Carlos Vergara é considerado um dos principais artistas da vanguarda neofigurativa brasileira entre os anos de 1950 e 1960. 9 Técnica de impressão feita em uma superfície lisa, não absorvente. Trata-se de uma impressão única, já que a maior parte da tinta costuma se depositar na superfície na prensagem inicial.

10 Georges Didi-Huberman desdobra este tema no livro La ressemblance par contact: archéologie, anachronisme et modernité de l'empreinte. Paris: Les Éditions de Minuit, 2008. 


\section{REFERÊNCIAS}

AGAMBEN, Giorgio. O Fogo e o Relato: Ensaios sobre Criação, Escrita, Arte e Livros. Tradução de Andrea Santurbano e Patricia Peterle. 19 edição. São Paulo: Boitempo, 2018.

DIDI-HUBERMAN, Georges. Diante do Tempo: História da Arte e Anacronismo das Imagens. Tradução de Vera Casa Nova e Márcia Arbex. Belo Horizonte: Editora UFMG, 2015.

DIDI-HUBERMAN, Georges. Génie Du No-Lieu: Air, Poussière, Empreinte, Hantise. Paris: Éditions de Minuit, 2001.

GENET, Jean. O Ateliê de Giacometti. Tradução de Célia Euvaldo. São Paulo: Cosac \& Naify Edições, 2000.

LORD, James. Um Retrato de Giacometti. Tradução de Célia Euvaldo. São Paulo: lluminuras, 1998.

NANCY, Jean-Luc. El arte hoy. Tradução de Carlos Pérez López e Daniel Alvaro. 1 @ edição. Buenos Aires: Prometeo Libros, 2014.

NANCY, Jean-Luc. O Vestígio da Arte. In HUCHET, Stéphane (org). Fragmentos de uma Teoria da Arte. São Paulo: Editora da Universidade de São Paulo, 2012. p. 289-306.

SARTRE, Jean-Paul. Alberto Giacometti. Tradução de Célia Euvaldo. São Paulo: Editora WMF Martins Fontes, 2012.

VERGARA, Luiz Guilherme. Carlos Vergara: Sudário. Coordenação de Carlos Vergara. Tradução de Alex Forman. $1^{\underline{a}}$ edição. Rio de Janeiro: Automatica, 2014. 


\section{OS OBJETOS GRÁFICOS DE MIRA SCHENDEL: O SILÊNCIO DA FALA NA IMAGEM'}

Mira Schendel's Objetos gráficos: the silence of speech in image Los Objetos gráficos de Mira Schendel: el silencio del discurso en la imagen

> Thiago Grisolia Fernandes (Universidade Federal do Rio de Janeiro, Brasil)*

FERNANDES, Thiago Grisolia. Os Objetos gráficos de Mira Schendel: o silêncio da fala na imagem. Revista Poiésis, Niterói, v. 23, n. 39, p. 155-169, jan./jun. 2022.

Este documento é distribuído nos termos da licença Creative Commons Atribuição-Não Comercial 4.0 Internacional (CC-BY-NC) (C) 2022 Thiago Grisolia Fernandes. Submetido: 10/3/2021; Aceito: $25 / 5 / 2021$
RESUMO Este artigo propõe uma análise da série Objetos gráficos ( 1967/1973) de Mira Schendel, artista nascida na Suíça e radicada no Brasil, a partir da ideia do silêncio e da ausência implicados na linguagem. Três elementos principais são abordados nesta análise: a materialidade da letra, a transparência do suporte de acrílico e papel de arroz e a existência de várias camadas na obra, que garantem uma profundidade à mesma. A partir da leitura de autores como Haroldo de Campos, procuramos ainda inserir o trabalho de Mira Schendel dentro de um campo ampliado da poesia, esgarçando as fronteiras entre palavra e imagem no contemporâneo. PALAVRAS-CHAVE Mira Schendel; Objetos gráficos; silêncio; ausência.

ABSTRACT This article proposes an analysis of the series Objetos gráficos (1967/1973) by Mira Schendel, an artist born in Switzerland and based in Brazil, based on the idea of silence and absence implied in language. Three main elements are addressed in this analysis: the materiality of the letter, the transparency of the acrylic and rice paper support and the existence of several layers in the work, which guarantee its depth. Based on the reading of authors like Haroldo de Campos, we also try to insert Mira Schendel's work into a broader field of poetry, blurring the boundaries between word and image in the contemporary.

Keywords Mira Schendel; Objetos gráficos; silence; absence.

RESUMEN Este artículo propone un análisis de la serie Objetos gráficos (1967/1973) de Mira Schendel, artista nacida en Suiza y afincada en Brasil, a partir de la idea de silencio y ausencia implícita en el lenguaje. En este análisis se abordan tres elementos principales: la materialidad de la letra, la transparencia del soporte de acrílico y papel de arroz y la existencia de varias capas en la obra, que garantizan su profundidad. A partir de la lectura de autores como Haroldo de Campos, también intentamos insertar la obra de Mira Schendel dentro de un campo más amplio de la poesía, difuminando los límites entre palabra e imagen en lo contemporáneo. PALABRAS CLAVE Mira Schendel; Objetos gráficos; silencio; ausencia.

* Thiago Grisolia Fernandes é doutorando no Programa de Pós-Graduação em Ciência da Literatura da Universidade Federal do Rio de Janeiro. E-mail: goathigrisolia@yahoo.com.br. ORCID: https://orcid.org/0000-0002-0856-8528.

Revista Poiésis, Niterói, v. 23, n. 39, p. 155-169, jan./jun. 2022. [DOl: hittps://doi.org/10.22409/poiesis.v23i39.49097]. 
INTRODUÇÃO

Mira Schendel foi poeta, antes de se estabelecer como artista visual, uma das mais instigantes do Brasil do século XX, especialmente pela dificuldade - e pela falta de necessidade - de incluí-la em alguma vertente da história da arte, de filiá-la a alguma tendência estilística, embora isso tenha sido tentado, com mais ou menos sucesso. Haroldo de Campos, por exemplo, contrariando o movimento mais usual da crítica, que é o de tentar inseri-la em uma vertente mais ligada ao construtivismo e a algumas questões do Concretismo, em entrevista a Sônia Salzstein, afirma que lateral, apenas para chegar aí, onde sua atividade de poeta se revela insuficiente para dar conta de suas questões artísticas. Caberá lembrarmo-nos de seu nascimento em Zurique, na Suiça, em 1919, sua formação intelectual, já em artes, mas também em filosofia e teologia, na Itália, suas viagens em fuga da perseguição nazista, que a levaram a Sarajevo, Roma e, finalmente, em 1949, a Porto Alegre, no Brasil, país onde instalou-se definitivamente até a sua morte, em 1988. E, aqui, Mira inicia um diálogo com intelectuais e poetas importantes, como o físico Mário Schenberg e o poeta Haroldo de Campos, e desenvolve seu trabalho artístico, ao mesmo tempo em que leciona e publica poemas.

Seus poemas, tais como eram publicados no início aqueles com quem Mira teria mais ligação seriam o Hélio Oiticica, por alguns aspectos específicos, ligados ao trabalho mais pictural que ele realizou, e a Lygia Clark, por determinados esvaziamentos da forma que marcam alguns de seus objetos. Eu acho que os três formam uma constelação de artistas [CAMPOS, 1996, p. 241].

Consideramos fundamental iniciar este pensamento a respeito do trabalho de Mira Schendel, mais especificamente a respeito da série Objetos gráficos, realizada pela artista entre 1967 e 1973, com a afirmação de que ela foi poeta.

Por iniciar deste modo, é recomendável recorrer à sua biografia, mas apenas de maneira breve e de sua vida no Brasil, são difíceis de serem encontrados, e não nos caberia reproduzi-los aqui. O diálogo com a poesia que nos leva a iniciar este ensaio afirmando que Mira Schendel foi poeta se revelará manifesto ao longo de toda a sua trajetória artística, e se funda muito mais sobre uma perspectiva ampliada de poesia [uma perspectiva que seguiria as pistas oferecidas por Rosalind Krauss e indicaria um campo ampliado da poesia], que considera, inclusive, a poesia muito mais a partir de sua negatividade, de seu coeficiente silencioso; a partir daí, interessa observar que, já do nascedouro, a produção plástico-poética 
de Mira articula a palavra, a imagem e o silêncio através de um reviramento da linguagem, como procuraremos demonstrar a seguir.

Os Objetos gráficos evocam, de um modo muito singular, a ideia de vazio que permeia todo o trabalho de Mira, e por isso trataremos especificamente de tais trabalhos neste texto. Maria Eduarda Marques aponta-nos o seguinte:

A noção de vazio foi uma constante na obra de Mira, presente nas pinturas e, mais intensamente, nos desenhos que veio a realizar. 'O espaço vazio me comove profundamente', disse ela. É o vazio do sujeito imanente, no limiar de sua existência e expressividade, imerso 'nel vuoto del mondo' [no vazio do mundo] [...]. O vazio que se apresenta em suas pinturas não é apenas ausência de objetos representados no plano: evoca a ideia de uma negatividade produtiva [...]." [MARQUES, 2011, p. 19-20]

Trata-se, no trabalho em questão, de uma série de telas que "flutuam" pelo espaço expositivo presos por fios de náilon [como pode ser visto na figura 1]; as telas consistem em uma série de letras, algarismos e outros signos gráficos, datilografados ou adesivados, e outros símbolos não-gráficos, mas que remetem a espécies de rabiscos, manuscritos por Mira, dispostos sobre uma folha de papel de arroz prensada por duas camadas de acrílico, sobre as quais também são inseridos alguns símbolos. A cor de tudo isto é escura, quase preto-e-branco, ou sépia; os símbolos, como bem apontado por Ricar- do Nascimento Fabbrini, "são discretos, diminutos" [FABBRINI, 2002, s/p]. As letras pairam, flutuam pelo espaço; há profundidade, dada pelas camadas que se sobrepõem [letras sobre acrílico sobre letras sobre papel de arroz sobre letras sobre acrílico sobre letras]; e há, sobretudo, transparência.

O que salta aos ol hos nesses trabalhos de Mira são esses três elementos fundamentais: a presença da letra, dissociada da formulação de um vocábulo; a profundidade, embora pareça tratar-se de um plano; e a transparência da composição, que Ihe confere certa fragilidade, certa evanescência. Do intervalo entre esses elementos, entre essas exigências fundamentais dessas telas, portanto do silêncio que, essencialmente, há nessa composição, emerge o sentido que nos será caro em sua análise. 




Fig. 1 -Vista da exposição Tangled alphabets: León Ferrari and Mira Schendel, MoMA, 2009, com alguns trabalhos da série Objetos gráficos em destaque. [Fotografia de Jonathan Muzikar]

[Fonte: https://www.moma.org/calendar/exhibitions/299/installation_images/3951\#, acesso em 05/03/2021.] 
espectadores, fragilizados pela nossa necessidade de racionalizar, de pôr em palavras, de dar nossa palavra para tornar em verdades as coisas, de sa-

A "poética da letra", trabalhada pela artista Helena Trindade em ensaio que recebe justamente esse título, nos dá um bom caminho para pensar a letra tornada imagem, e a decorrente relação que se torna manifesta entre a escrita e a visualidade: ber o mundo através da palavra, que as ordenemos; que as coloquemos em relação; que as utilizemos para construir um sentido por vir; que imaginemos que há uma palavra oculta, por formar-se, por revelar-se no meio daquele turbilhão de ausências; que há talvez uma sentença primordial onde tudo o que vemos é ausência, onde só o que se nos mostra é "pura entropia" [FABBRINI, 2002, s/p], como diria o pesquisador Ricardo Fabbrini a respeito da obra de Mira. Não nos parecerá tentador achar justamente a palavra "palavra" no canto direito do Objeto mostrado a seguir [figura

É interessante observar o trabalho de Mira por essa perspectiva; buscar o vazio daquelas letras, que não foi abolido delas quando receberam o novo estatuto de imagens; observar que sua presença não completa a imagem, mas a "des-completa". Mas a letra talvez nunca possa vir a ser um signo puramente visual, plástico, principalmente no trabalho de Mira. Isso porque, sobretudo nesses trabalhos, pelo fato de as letras estarem aproximadas umas das outras, avizinhadas, há um chamamento ao sentido, à palavra, ao verbo. Essa composição, por mais que se quisesse puramente visual, pede a nós,
2], como se se tratasse de um jogo, de um caça-palavras, de um desafio cartesiano, e "desvendar", assim, o sentido da obra?

página seguinte

Fig. 2 - Mira Schendel, série Objetos gráficos, 1997/1973

Tipografia, grafite e óleo sobre papel entre placas de acrílico tipografadas, $100 \times 100 \mathrm{~cm}$.

[Fonte: https://www.moma.org/collection/works/108826, acesso em 05/03/2021.] 
Mesmo sabendo que "tornada objeto, a letra fica opaca e resiste ao sentido" [RIVERA, 2009, p. 125], nós quase nunca resistimos a atribuir-Ihes sentidos. Mesmo sabendo que

a partir de sua aparente irredutibilidade, a letra pode ser pensada como o resultado de um processo radical de essencialização e adensamento da linguagem que se presta muito bem a uma visualidade de concisão e economia de meios [TRINDADE, 2013, p. 23],

e que "o exemplo mais puro do significante é a letra" [LACAN apud TRINDADE, 2013, p. 23], ainda assim não cessamos de buscar o significado como duplo do significante, mesmo do mais "puro" deles, de não aceitar da linguagem seu adensamento e fazê-la espargir-se, transbordar. Resistir a isso seja talvez uma chave de entrada fundamental para o trabalho de Mira Schendel e por isso, pensando esse trabalho, Vilém Flusser afirma: "São as letras em formação que demandam o significado. São os enxames de letras que demandam o sentido. São as metamorfoses de letras que demandam as regras do jogo do pensamento" [FLUSSER, 1996, p. 265].

Mas é interessante retornar à ideia de que a letra, "tornada objeto, [...] fica opaca e resiste ao sentido" $\square$. É dessa opacidade, dessa resistência ao sentido advinda da opacidade, que nasce o elemento mais forte, mais importante para este estudo presente nos Objetos gráficos. Porque, nesses trabalhos, a letra, "tornada objeto", tem sua opacidade irrevogavelmente contrastada à transparência do suporte em que é colocada. A opacidade da letra tornada objeto põe em jogo a relação entre os três elementos que, acima, afirmamos serem os mais potentes da série de Mira: a presença da letra, a profundidade e a transparência. É porque a letra é opaca que nos damos conta de que os suportes são transparentes; é porque ela é opaca que, vetando a observação das camadas, anuncia a existência das camadas, pela via negativa; e é porque ela é opaca que a vemos, que a percebemos como tal: letra, símbolo gráfico; letra, objeto gráfico. E é porque ela resiste ao sentido que, de seu silêncio, o sentido emerge: e o silêncio é o sentido, ou, como disse Helena Trindade, o vazio é o que ela, a letra, diz.

\section{A TRANSPARÊNCIA, A PROFUNDIDADE}

É preciso resistir ao sentido diante de uma obra como esta, em que fala o silêncio - o silêncio da letra, exigência daquela tela, necessária para compor o todo transparente e profundo [silencioso] de que faz parte. Mas resistir ao sentido talvez não seja renunciar à história, à biografia.

E volta o dado de que Mira Schendel chegou ao Brasil refugiada da perseguição nazista na Europa; 
volta o dado de que Mira nasceu na Suíça, mas viveu na Itália, Bósnia, Brasil; vem o dado de que a guerra é sempre uma experiência-limite para a formulação de qualquer linguagem, pois é aquilo sobre o que nada se pode dizer; é aquilo que interrompe sua enunciação mesma. Certamente nada de sua produção artística completa-se em algum desses dados; mas há que se levar em consideração que há, neles, muito de silêncio, de ausência. Benjamin afirma que os soldados voltaram da Primeira Guerra Mundial em silêncio; a experiência de que se tratava era incomunicável: para ele, "os livros de guerra que inundaram o mercado literário nos dez anos seguintes não continham experiências transmissiveis de boca em boca" [BENJAMIN, 1994, p. 115]. E há uma relação inegável entre o vazio da experiência da guerra e a frieza das letras tipografadas, dos símbolos gráficos que procuram dizer o mundo, porém nada dizem, porque já não podem dizer. Em livro escrito durante a Segunda Guerra, no poema A flor e a náusea, o poeta mineiro Carlos Drummond de Andrade bem declara: "Os homens voltam para casa. / Estão menos livres mas carregam jornais, / e soletram o mundo, sabendo que o perdem". A incomunicabilidade da experiência, que Benjamin, em seu ensaio de 1933, diz ter se tornado estrutural no homem do pós-guerra, e sobre a qual Drummond, em seu A rosa do povo, escrito durante a Segunda Guerra, tão oportunamente escreveu em alguns de seus melhores versos [como o mencionado acima], também é a pontada pela própria Mira como elemento constitutivo de seu trabalho. Contudo, embora compreenda que essa experiência não apenas a experiência da guerra; a experiência, de uma maneira geral - seja incomunicável, ela não a vê sob o prisma da pobreza, como o faz Benjamin, mas exatamente ao contrário. Diz ela: a vida imediata, aquela que sofro, e dentro da qual ajo, é minha, incomunicável, e portanto sem sentido e sem finalidade. $O$ reino dos símbolos, que procuram captar essa vida [e que é o reino das linguagens], é, pelo contrário, anti-vida, no sentido de ser intersubjetivo, comum, esvaziado de emoções e sofrimentos. Se eu pudesse fazer coincidir estes dois reinos, teria articulado a riqueza da vivência na relativa imortalidade do signo [SCHENDEL, 1996, p. 256, grifo nosso].

E parece-nos que Mira, a seu modo, de fato consegue efetuar essa coincidência: o signo, "relativamente" imortal, ou seja, de alguma maneira a linguagem, que é o reino no qual procura-se captar, para transmitir, a experiência [a própria vida], comunica, em sua obra, justamente o incomunicável: enuncia o que não pode ser enunciado, e portanto é silêncio, e dá a ver o que é invisível. E parece-nos que Mira só consegue fazê-lo, só consegue alcançar essa coincidência do reino da experiência, 
da vida, com o reino dos símbolos, da linguagem, através da transparência, que, na série dos Objetos gráficos, é justamente o que confere a ele a profundidade que citamos. Maria Eduarda Marques, em estudo sobre a obra de Schendel, diz: de imortalizar o fugaz e dar sentido ao efêmero. Para poder fazê-lo é óbvio que devo fixar o próprio instante, no qual a vivência se derrama para o símbolo, no caso, para a letra.

No começo, pensava que para tanto bastava [...] sentar-me a esperar que a letra se forme. Que assuma sua
Na densidade do desenho e das inscrições, a transparência alcançada na montagem do papel sobre o acrílico é fundamental. [...] o papel é prensado por entre duas placas de acrílico, suspensas por fios de náilon, tornando visível a outra face do plano. A hierarquia do olhar é quebrada, conduzindo a uma leitura circular e virtual. Mira explora a possibilidade de acabar com a frente e o verso. Interessava a ela alcançar a simultaneidade do tempo e do espaço. [MARQUES, 2011, p. 27]

Mas a própria Mira elabora melhor o caminho que a fez chegar no acrílico e a potência do acrílico enquanto transparência para seu trabalho. Embora longo, presumimos ser imprescindivel lançar mão deste trecho integralmente. No decorrer de suas palavras, retiradas de uma anotação sem data, sem título, incluída por Sônia Salzstein em volume que organizou sobre a obra de Schendel, podemos observar muitas das coisas que viemos discutindo elaboradas pela própria artista - rica contribuição sobre o papel da letra, da transparência e da profundidade em sua obra.

que me preocupa é captar a passagem da vivência imediata, com toda a sua força empírica, para o símbolo, com toda a sua memorabilidade e relativa eternidade. [...] Reformulando, é esta minha obra a tentativa forma no papel e que se ligue a outras numa escrita pré-literal e pré-discursiva. Mas sentia, desde o início, que isto poderia ter êxito apenas se o papel fosse transparente. Agora sei melhor avaliar porque tinha então aquela impressão: a letra, ao formular-se, deve mostrar o máximo de suas faces, para ser ela mesma.

Surgiu, no entanto, um segundo problema. A sequência de letras no papel imita o tempo, sem poder realmente representá-lo. São simulações do tempo vivido, e não captam a vivência do irrecuperável, que caracteriza esse tempo. Os textos que desenhei no papel podem ser lidos e relidos, coisa que o tempo não pode. Fixam, sem imortalizar, a fluidez do tempo. Por isso, abandonei esta tentativa.

Abandonei, porque descobri o acrílico, que parece oferecer as seguintes virtualidades: a. torna visível a outra face do plano, e nega, portanto, que o plano é plano; $b$. torna legível o inverso do texto, transformando portanto o texto em anti-texto; c. torna possivel uma leitura circular, na qual o texto é centro imóvel e o leitor é móvel. Destarte, o tempo fica transferido da obra para o consumidor, portanto o tempo se lança do símbolo de volta para a vida; $d$. a transparência que caracteriza o acrílico é aquela falsa transparência do sentido explicado. Não é a transparência clara e chata do vidro, mas a transparência misteriosa da explicação, de problemas. [SCHENDEL, 1996, p. 256] 
Portanto, para Mira, está no material a chave para essa leitura de sua obra; não terá sido à toa que Haroldo de Campos, em entrevista, afirmou que Mira "tem esse grande respeito matérico pelos elementos que convoca em seu trabalho" [CAMPOS, 1996, p.

234]. Do acrílico, de sua potência enquanto material, advêm a negação do plano, que é a profundidade em que temos insistido, e a possibilidade de o "inverso" do texto ser lido, gerando a possibilidade mesma de que se experimente a escrita, ou antes o avesso da escrita [a desescrita, poderíamos dizer] com o corpo - e, talvez, trate-se sempre disso; talvez a desescrita, esse avesso de um texto que lhe é constitutivo, só seja experimentado através de uma operação com o corpo, de uma transferência de tempo da obra para o corpo de seu "leitor", de uma "leitura circular" que possibilita que o tempo seja lançado "do símbolo de volta para a vida". E se Benjamin abomina os ambientes de vidro, sob a justificativa de que "eles criaram espaços em que é difícil deixar rastros" [BENJAMIN, 1994, p. 118], Mira Schendel recusa também o vidro, deixa como rastro o vazio que nada tem a ver com a falta, com a "transparência chata do vidro", com sua assepsia demasiada.

Além da opacidade da letra e da transparência do suporte, há no trabalho de Mira Schendel ainda um outro elemento que, sendo a colocação dos dois primeiros em perspectiva, um em relação ao outro, é aquele que nos revela de forma mais contundente a potência da fragilidade, do silêncio e mesmo da ausência implicados em sua obra. Tal elemento nos é oferecido a partir da ideia das camadas. Segundo a própria Mira, a existência de várias camadas em seu trabalho, através de uma das "virtualidades" do acrílico, nega o plano, indica que "o plano não é plano", denuncia a existência de profundidade, por mais que se trate de uma tela. A ideia de profundidade é este terceiro elemento, que a existência de camadas em seus Objetos gráficos revela.

Em toda tela há a existência de camadas, mesmo que seja, minimamente, a da tinta por sobre a tela [mas há, na maioria dos casos, tintas sobre tintas, e, ainda, outros materiais, que têm sido utilizados das formas mais inusitadas na arte de nosso tempo]. E essa existência de camadas, que confere profundidade material à tela [não estamos nos referindo à profundidade virtual, produzida tecnicamente através da perspectiva], é o modo pelo qual se consegue destacar os elementos que compõem o quadro; é pela existência das camadas que o intervalo entre elas, o vazio entre os signos que fazem parte da composição, irrompe, e é a partir de onde o sentido pode se fazer. Nos Objetos de Mira, essa profundidade é apenas mais bem observada, potencializada pelo acrílico; por isso seu silêncio é tão potente, tão forte, tão eloquente. 
Mira Schendel atinge visualmente o ponto onde o silêncio emerge da fala, ainda que sua fala seja apenas, como ela mesma aponta, pré-literal, pré-discursiva; esse ponto que é comum à fala dos poetas. Seu trabalho, portanto, se é que pode ser considerado um poema, só pode ser assim considerado pela via do silêncio, e não da voz; pela via do intervalo, da ausência, e não tanto da presença das letras. E, embora uma parte da crítica não admita seu trabalho enquanto poesia, como Fabbrini, quando afirma que

as 'miragrafias', todavia, não são 'poemas', mas a figuração de um estado anterior ao nascimento das línguas, um regresso ao 'in nato' das letras, dos algarismos e de suas primeiras conexões [FABBRINI, 2002, s/p],

Haroldo de Campos diz o contrário. Afirma a potência poética do trabalho da amiga Mira Schendel em dois momentos importantes. O primeiro deles é na já referida entrevista a Sônia Salzstein, quando declara o seguinte:

Ela tem esse grande respeito matérico pelos elementos que convoca no seu trabalho e, por outro lado, tem o gosto pela escritura. Esta nem sempre é létrica, às vezes não são letras nem palavras; outras vezes aparecem palavras, e o quadro dela já é um poema, um poema-quadro, um quadro-poema. Certas escrituras são traços, são resíduos, são resquícios, são restos que ela deixa no papel, deixa aflorar no papel, deixa percorrer o papel, como se fossem rastros existenciais, ontológicos. [CAMPOS, 1996, p. 234]

O outro momento é quando escreve um poema, publicado originalmente no catálogo Mira Schendel, relativo à exposição da artista no MAM/RJ, em 1966, e republicado no livro organizado por Salzstein, no qual Haroldo consegue captar, com a excelência poética exigida, essa "arte de vazios" de Mira Schendel.

\section{uma arte de vazios}

onde a extrema redundância começa a gerar informação original uma arte de palavras e de quase palavras

onde o signo gráfico veste e desveste vela e desvela súbitos valores semânticos

uma arte de alfabetos constelados

de letras-abelhas enxameadas ou solitárias $a-b-[l i]-a a$

onde o dígito dispersa seus avatares num transformismo que visa ao ideograma de si mesmo que força o digital a converter-se em analógico uma arte de linhas que se precipitam e se confrontam por mínimos vertiginosos de espaço sem embargo habitados por distâncias insondáveis de anos-luz uma arte onde a cor pode ser o nome da cor 
e a figura comentário da figura

para que entre significante e significado

circule outra vez a surpresa

uma arte-escritura

de cósmica poeira de palavras

uma semiótica arte de ícones índices símbolos

que deixa no branco da página seu rastro luminoso

esta arte de mira schendel

entrar no planetarium onde suas composições

se suspendem desenhos estelares

e ouvir o silêncio como um pássaro de avessos

sobre um ramo de apenas

gorjear seus haicais absolutos [CAMPOS, 1996, p. 239]

A "arte de alfabetos constelados" de que fala Haroldo remete à ideia de "constelação", muito cara a este teórico, e que pode ser aplicada ao trabalho de Mira Schendel. Tomada do texto de Eugen Gomringer, Do verso à Constelação - Função e Forma de uma Nova Poesia, essa ideia aparece em diversos de seus textos mais importantes, e refere-se a um modo outro de pensar a poesia, para além do verso tal como é tradicionalmente conhecido; para pensar este modo outro, tanto Gomringer quanto Haroldo de Campos recorrem à escrita ideogrâmica chinesa, cujo método de composição poética, de acordo com Haroldo, via Ezra Pound, é o de “justaposição direta de elementos em conjuntos geradores de relações novas [o que Gomringer, a exemplo de Mallarmé, denomina de constelação]" [CAMPOS, 2006, p. 141].

Evidentemente, a constelação de que falam Gomringer e Campos refere-se à poesia; e a uma poesia necessariamente feita com palavras. Embora partindo

da consideração do instrumento ideográfico como o processo mental de organização do poema em exata consonância com a urgência por uma comunicação mais rápida, direta e econômica de formas verbais que caracteriza o espírito contemporâneo, antidiscursivo e objetivo por excelência [CAMPOS, 2006, p. 142],

e concebendo o poema "como uma unidade totalmente estruturada de maneira sintéticoideogrâmica [todos os elementos sonoros, visuais e semânticos - verbivocovisuais - em jogo]" [CAMPOS, 2006, p. 142], é importante ressaltar que "a constelação é a forma mais simples de organizar a poesia fundada na palavra" [GOMRINGER apud CAMPOS, 2006, p. 141, grifo nosso].

E, como já vimos, a escritura que está em jogo no trabalho de Mira Schendel, ao mesmo tempo em que se aproxima, pela via da ausência, da poesia - pelo menos de sua essência -, não chega a se constituir enquanto poema feito de palavras: 
é uma "escrita pré-discursiva", anterior à formulação de uma palavra que pudesse se colocar em relação a outras, num jogo constelado. O que se coloca em constelação, aqui, não são as palavras, mas, talvez, como no poema de Haroldo, apenas essa "cósmica poeira de palavras", isto é, as letras.

E é no intervalo entre essas letras, como já vimos, que emerge o teor poético de sua obra, deixando "no branco da página seu rastro luminoso". Mais próximas dos ideogramas do que as palavras em caracteres ocidentais, as letras - cada um dos caracteres per se - é que, em seu trabalho, adquirem uma forma. "Não basta afirmar", diz Fenollosa a respeito dos ideogramas, "que cada um deles encerra um determinado corpo de significado prosaico; pois a questão é como pode o verso chinês implicar, enquanto forma, o elemento que distingue a poesia da prosa?" [FENOLLOSA, 1977, p. 121]. A mesma questão se pode colocar em relação às letras de Mira, na composição não de um verso poético, mas de uma tela que encerra um enunciado potencialmente poético. Nesses objetos gráficos, os alfabetos são constelados, as letras são abelhas enxameadas, que fazem ouvir seu silêncio como um pássaro de avessos.
Colocando em questão a ideia de que o pensamento, naturalmente, ainda segundo Fenollosa, "é sucessivo, não em virtude de algum acidente ou fraqueza de nossas operações subjetivas, mas porque as operações na Natureza são também sucessivas" [FENOLLOSA, 1977, p. 121], Mira, com suas letras não sucessivas, mas consteladas, propõe uma nova ordem do pensamento. Fenollosa se pergunta "em que sentido versos escritos sob a forma de hieróglifos visíveis podem ser tidos por verdadeira poesia?", considerando que
Aparentemente, talvez, a poesia que, tal como a música, é uma arte do tempo, entretecendo suas unidades através de sucessivas impressões sonoras, dificilmente poderia assimilar um meio de comunicação verbal que consiste, em grande parte, de apelos semipictóricos ao olho. [FENOLLOSA, 1977, p. 120]

Revista Poiésis, Niterói, v. 23, n. 39, p. 155-169, jan./jun. 2022. [DOl: hitps://doi.org/10.22409/poiesis.v23i39.49097]

Embora não sejam exatamente "hieróglifos", as "miragrafias", como chamadas por Fabbrini, nos oferecem, de algum modo, uma resposta a essa pergunta. Fazendo outra vez circular a surpresa entre significante e significado - um significante sempre por vir, potência, portanto, de significados sempre múltiplos -, a artista nos oferece uma transferência de tempo da obra para o consumidor [em suas palavras: "o tempo se lança do símbolo de volta para a vida" [SCHENDEL, 1996 , p. 256]]: sua arte se dá no tempo, como a poesia, 
mas não de maneira sucessiva, e sim circular.

Mira nos permite experimentar, da escritura, seu

avesso, fazendo o espectador submeter-se a ele, "entrar no planetarium onde suas composições/ se suspendem desenhos estelares", ouvir o gorjeio desse "pássaro de avessos" a relativizar seus "haicais absolutos"; permite-nos, enfim, entrar na dobra de sua escritura, onde a ausência da palavra é eloquente, e encontrar em seus Objetos uma potente desescrita.

\section{NOTAS}

1 Este artigo foi escrito com o auxilio da bolsa de pesquisa de doutorado do CNPq.

2 Esta análise de Tania Rivera não refere-se ao trabalho de Mira Schendel; antes, refere-se ao trabalho da artista Helena Trindade, e consta no catálogo de uma exposição dela. Achamos, todavia, adequado inserir esta análise aqui. 


\section{REFERÊNCIAS}

BENJAMIN, Walter. Experiência e pobreza. In BENJAMIN, Walter. Magia, técnica, arte e polífica. Tradução de Sérgio Rouanet. São Paulo: Brasiliense, 1994.

CAMPOS, Haroldo de. Entrevista a Sônia Salzstein. In SALZSTEIN, Sônia (org.). no vazio do mundo: Mira Schendel. São Paulo: Marca d'Água, 1996.

CAMPOS, Haroldo de. da fenomenologia da composição à matemática da composição. In CAMPOS, Augusto de; CAMPOS, Haroldo de; PIGNATARI, Décio (orgs.). Teoria da poesia concreta: textos críticos e manifestos 1950-1960. Cotia: Ateliê Editorial, 2006.

FABBRINI, Ricardo Nascimento. Miragrafias. Folha de S. Paulo. Jornal de resenhas. 13 de abril de 2002. Disponível em https://www 1. folha.uol.com.br/fsp/resenha/rs 1304200210.htm, acesso em 05/03/2021.

FENOLLOSA, Ernest. Os caracteres da poesia chinesa como instrumento para a poesia. In CAMPOS, Haroldo (org.). Ideograma: lógica, poesia, linguagem. Textos traduzidos por Heloysa de Lima Dantas. São Paulo: Cultrix; Editora da Universidade de São Paulo, 1977.

FLUSSER, Vilém. Indagações sobre a origem da língua. In SALZSTEIN, Sônia (org.). no vazio do mundo: Mira Schendel. São Paulo: Marca d'Água, 1996.

MARQUES, Maria Eduarda. O lugar da pintura na obra de Mira Schendel. In Mira Schendel pintora. Catálogo de exposição. Instituto Moreira Salles, 2011.

RIVERA, Tania. A casa da letra. In TRINDADE, Helena. LIVROs. Rio de Janeiro: Contra Capa, 2009.

SALZSTEIN, Sônia (org.). no vazio do mundo: Mira Schendel. São Paulo: Marca d'Água, 1996.

SCHENDEL, Mira. Sem título. In SALZSTEIN, Sônia (org.). no vazio do mundo: Mira Schendel. São Paulo: Marca d'Água, 1996.

TRINDADE, Helena. Poética da letra. In SARAIVA, Alberto (org.). Poesia visual. Rio de Janeiro: F10 Editora; Oi Futuro, 2013.

Revista Poiésis, Niterói, v. 23, n. 39, p. 155-169, jan./jun. 2022. [DOl: hitps://doi.org/10.22409/poiesis.v23i39.49097] 


\section{ABRAHAM PALATNIK: A LUZ COMO EXPRESSÃO PLÁSTICA}

Abraham Palatnik: light as plastic expression

Abraham Palatnik: la luz como expresión plástica

> Almerinda da Silva Lopes (Universidade Federal do Espírito Santo, Brasil)*

LOPES, Almerinda da Silva. Abraham Palatnik: a luz como expressão plástica. Revista Poiésis, Niterói, v. 23, n. 39, p. 170-186, jan./jun. 2022. [DOI: https:// doi.org/10.22409/ poiesis.v23i39.50822]

Este documento é distribuído nos termos da licença Creative Commons Atribuição Não Comercial 4.0 Internacional (CC-BYNC) (C) 2022 Almerinda da Silva Lopes.

Submetido:

13/7/2020; Aceito:

$31 / 8 / 2021$
RESUMO $O$ texto reflete sobre a criação do Aparelho Cinecromático de autoria do brasileiro Abraham Palatnik (1925-2019) e sua participação na I Bienal Internacional de São Paulo (1951), bem como a dificuldade da crítica brasileira em dialogar com o inusitado objeto dotado de luz em movimento, por se distanciar do tradicional duopólio artístico, embora o mesmo não deixasse de se insinuar simultaneamente como objeto escultórico e pictórico. Embora esse pioneiro objeto cinético não deixasse de se mostrar tributário do Modulador de Espaço-Luz (1930), de autoria do artista húngaro Moholy-Nagy, o brasileiro Abraham Palatnik revelou ousadia e perseverança ao criar sua primeira obra luminocromática em um país que, na época, era muito defasado tecnologicamente.

PALAVRAS-CHAVE arte cinética; Abraham Palatnik; aparelho cinecromático; arte e tecnologia; relação espaço/luz/tempo

*Almerinda da Silva Lopes é Professora e Pesquisadora dos Programas de Pós-Graduação em Artes (PPGA) e em História (PPGHIS) da Universidade Federal do Espírito Santo (UFES). E-mail: almerindalopes579@gmail.com. Orcid: https://orcid.org/0000-0001-50757843 0000-0001-5075-7843 
ABSTRACT The text reflects on the creation of the Cinechromatic Apparatus authored by the Brazilian Abraham Palatnik (1925-2020) and his participation in the 1st São Paulo International Biennial (1951), as well as the difficulty of Brazilian critics to dialogue with the unusual object endowed with light in movement, for distancing itself from the traditional artistic duopoly, although it did not fail to insinuate itself simultaneously as a sculptural and pictorial object. Although this pioneering kinetic object was still a tributary of the Space-Light Modulator (1930), by the Hungarian artist Moholy-Nagy, the Brazilian Abraham Palatnik showed boldness and perseverance when creating his first lumino-chromatic work in a country which, at the time, was very technologically outdated.

KEYWORDS Kinetic Art; Abraham Palatnik; kinechromatic apparatus; art and technology; space/light/ time relation

RESUMEN El texto reflexiona sobre la creación del Aparato Cinecromático, del brasileño Abraham Palatnik (1925-2019) y su participación en la I Bienal Internacional de São Paulo (1951), así como la dificultad de la crítica brasileña para dialogar con el objeto insólito dotado de luz en movimiento, por alejarse del tradicional duopolio artístico, aunque no deja de insinuarse a la vez como objeto escultórico y pictórico. Aunque este objeto cinético pionero era todavía afluente del Space-Light Modulator (1930), del artista húngaro Moholy-Nagy, el brasileño Abraham Palatnik mostró audacia y perseverancia al crear su primera obra lumino-cromática en un país que, en ese momento, estaba muy desactualizado tecnológicamente. PALABRAS CLAVE arte cinético; Abraham Palatnik; aparato cinecromático; arte y tecnología; relación espacio/ luz/tiempo 


\section{INTRODUÇÃO}

A Revolução Industrial instaurou um processo de crise e de ruptura com os valores espirituais e os paradigmas estéticos do passado. Gerou, ainda, um clima propício ao capitalismo, ao racionalismo e à difusão da ideia de progresso, associados a uma nova ordem social e econômica pautada no funcionalismo da máquina, que assumia o papel de libertadora do trabalhador moderno. A eficiência da máquina possibilitaria o aumento da produção e estimularia o consumo, que trariam mudanças na estrutura urbana, no pensamento e nos modos de vida.

A esse "espírito positivo", de base instrumental e pragmática, vinculava-se, ainda, a ideia de autonomia do fenômeno criativo e de um novo estatuto da arte. Os artistas passariam, então, a dialogar mais efetivamente com a ciência e a recorrer às novas tecnologias disponíveis. Buscariam, ainda, angariar melhor posição social competindo livremente no mercado e comercializando os objetos artísticos com quem tivesse interesse e recursos para adquiri-los.

O desenvolvimento das tecnologias e de materiais industriais possibilitou a descoberta da fotografia, da luz elétrica e do cinematógrafo, fenômenos que fascinaram os artistas e lhes impuseram novos desafios, entre eles a possibilidade de solucionar duas antigas aspirações: pintar com a luz e demover a arte de sua característica imobilidade. Com base na tecnologia e nos conhecimentos científicos, as vanguardas mais radicais formularam novos paradigmas para a arte, subvertendo o antigo sistema de representação e os valores estéticos passadistas.

A arte deixava de pautar-se numa ordem espiritual, para inserir-se como meio de expressão, conhecimento específico e bem de mercado. Com os avanços tecnológico e industrial, a arte deixava de ser produto executado exclusivamente de maneira manual e até individual. Os artistas passam a legar a execução de determinadas obras a terceiros ou aos operários das fábricas, prática essa adotada pela Bauhaus, no início do século passado, instituição que propugnou abolir a fronteira entre o artista e o artesão, criador e executor, e que também contribuiu para os primórdios da arte cinética na Europa, como veremos.

Ao vincularem a praxe artística ao espírito funcionalista da vida moderna, os artistas passam a investir em dispositivos tecnológicos, objetivando imprimir dinamismo às formas, linhas e cores. Os antigos efeitos gráficos obtidos com hachuras e sombreados, para simular o movimento de cabelos, roupas, volume do corpo humano e outros entes da natureza, passam a ser questionados e rejeitados por 
seu caráter ilusório, sendo substituídos por artifícios eletromecânicos e materiais industriais.

Se a invenção da fotografia não solucionara essa aspiração, logo surgiriam outras experiências articuladas na simbiose arte/ciência, visando demover os objetos artísticos da imobilidade. Essas pesquisas implicaram o surgimento de novos dispositivos tecnológicos e o aperfeiçoamento dos processos fotográficos, possibilitando gerar imagens dotadas de luz e movimento, pôr em xeque o espaço euclidiano, a perspectiva linear e desmontar algumas concepções da pintura retiniana. O processo mimético ou representativo do mundo objetivo ou analógico seria ironizado e confrontado, abrindo espaço à experiência criativa e ao pensamento científico.

\section{OS NOVOS MECANISMOS PARA IMPRIMIR MOVIMENTO ÀS FORMAS}

Alguns investimentos científicos e a fotografia mostraram que o mundo é dinâmico, modificando-se constantemente, o que contribuiu para repensar os processos de criação em vigor. A fotografia, além de modificar a geração de imagens e instigar o estatuto de arte, imporia mudanças na maneira de compreender e representar o mundo, especialmente a partir do impressionismo, quando a "representação imutável das coisas era abalada e relativizada" e sua "aparência passava a ser determinada pelo Tempo, pela Luz e pelo Movimento" [BIHALJI-MERIN, 1970, p. 60-61].

O advento da luz elétrica, na segunda metade do século XIX, possibilitou a criação do cinema, solucionando, finalmente, a dificuldade de imprimir movimento às imagens. Embora esse movimento fosse apenas ficcional, o cinema iludiria o olho, fazendo-o acreditar que tudo é instável ou se movimenta. Na verdade, é a projeção sequencial e simultânea de uma mesma imagem que gera essa percepção postiça de mundo dinâmico, levando o olho a visualizar as imagens como se dotadas de movimento real. O cinema criava, assim, uma nova "subjetividade e um novo conceito de verdade, que emerge da imaginação e impede distinguir o falso do verdadeiro, a cópia do original, a realidade da ilusão". Além disso, o tempo no movimento do cinema transcorre de maneira "muito mais rápida ou mais lenta do que aquele que vivemos" [PARENTE, 1993, p. 16-20].

O caráter enunciativo do cinema e seu princípio de homogeneização fascinaram os artistas vanguardistas, em especial cubistas, futuristas e construtivistas. Esses exaltaram, em seus respectivos programas teóricos e estéticos, a velocidade da máquina, o cinema, a indústria e as massas urbanas em movimento, em ambientes de diversão ou 
rumando para o trabalho nas efervescentes metrópoles modernas. O cinema transforma-se, assim, na expressão do futuro, desbancando a pintura e a escultura, que deixariam de ser meios privilegiados de informação e de representação visual. Tornou, ainda, os artistas conscientes da impossibilidade de criar obras em movimento se não recorressem a artifícios eletromecânicos, o que Ihes impôs inevitáveis desafios técnicos para desenvolverem experiências nesse âmbito. Isso não impediria, porém, que um número significativo de signatários desenvolvesse, individualmente ou em parceria com técnicos e engenheiros, ainda no início do século XX, experiências no campo artístico e cinematográfico, recorrendo a inusitadas engenhocas mecânicas com tal finalidade, que levariam à criação dos primeiros objetos cinéticos, palavra derivada do inglês Kinetic [ou do grego Kinetiké=cinemático]. vale citar, entre outras, as pesquisas experimentais realizadas por Léger, Picabia e Duchamp, respectivamente em Ballet Mécanique, Entr'acte e Anémic Cinéma, entre 1924 e 1926. Léger já havia realizado, em conjunto com Abel Gance, o filme La Roue[A Roda, 1922] e publicado textos reveladores de seu fascínio pela máquina e pela vida moderna.

O aumento da produção de materiais industriais e de novas tecnologias, a partir dessa mesma década, possibilitou o desenvolvimento de engenhocas artísticas pioneiras, dotadas de luz e movimento. Consistiam em objetos movidos por pequenos motores, como os de autoria de Naum Gabo, Marcel Duchamp e Moholy-Nagy. Quando acionados, alguns componentes desses objetos esculturais se movimentavam, produzindo algum tipo de ação, efeito visual, luminoso ou sonoro.

Em colaboração com um engenheiro, Marcel Duchamp construiu seu primeiro mecanismo ótico, as Placas de vidro rotativas [1923], seguido de outra proposta mais sofisticada, a Semi-esfera Rotativa [Ótica de Precisão, 1925]. Trata-se de objeto-máquina de pequenas dimensões, dotado de uma forma circular de madeira, pintada de branco, contendo uma incisão no centro, sobre a qual o artista desenhou círculos concêntricos pretos. Essa peça foi montada "sobre um disco de cobre, e escondida em uma redoma de vidro coberta de veludo preto". Impulsionado por pequeno motor, o disco girava, fazendo com que as linhas das circunferências concêntricas pintadas em sua superfície "parecessem mover-se para frente e para trás no espaço" [TOMKINS, 2004, p. 284].

O húngaro Lászlo Moholy-Nagy [1895-1946] desenvolveu, nessa época, pesquisas em diferentes linhas de investigação: pintura, escultura, fotografia, cinema, design. Os conhecidos fotogramas criados pelo artista, resultantes do posicionamento de objetos so- 
bre superfícies de papel fotossensível, concretizaram sua vontade de desenhar com a luz. Esses desenhos fotográficos redimensionaram seu interesse por materiais industriais e processos artísticos inusitados, e desencadearam o desenvolvimento de novas experiências artísticas, quando se declarou também instigado pela pintura Quadrado branco sobre fundo branco [1918], de Malevich, e pela atmosfera criada pela luz elétrica sobre a paisagem urbana. As experimentações com luz, cor, forma e movimento levaram Moholy-Nagy a profetizar, ainda, sobre a mudança de postura do espectador, mencionando em manifesto lançado em parceria com Alfred Kemeny, em 1922, que o público passaria de contemplador passivo à posição de participante ativo da obra de arte [BARRET, 1991, p. 153].

As experiências artísticas e concepções teóricas de Moholy-Nagy foram explicitadas no livro The New Vision [1928], desenvolvidas enquanto era professor da Bauhaus [1923-1928], em que refletiu sobre espacialidade, luminosidade e desmaterialização, sobre os efeitos do movimento e da luz sobre a percepção e a recepção dos novos objetos artísticos, que o levaram à criação da primeira escultura cinética: Modulador de Espaço-Luz [Light-Space Modulator, 1922-1930].

Essa complexa estrutura rotativa reuniu variados objetos e materiais: prismas, espelhos, cerca de 70 lâmpadas elétricas, brancas e coloridas, refletores, discos perfurados de metal polido, grades aramadas, esfera de madeira, motor elétrico escondido na base circular da escultura, correntes e rolamentos. O motor fazia a peça girar e as lâmpadas acenderem, emitindo luz que reverberava sobre as superfícies metálicas, criando sombras misteriosas e curiosos efeitos luminoespaciais.

O Modulador foi exibido pela primeira vez na exposição da Federação Alemã de Trabalho, em Paris [1930]. Os efeitos luminosos produzidos pelo objeto-máquina foram registrados, no mesmo ano, no filme dirigido pelo artista, Light Display Black-White-Grey [16 mm]. O aparelho foi utilizado, depois, para produzir efeitos luminosos e ritmos dinâmicos e esfuziantes em fachadas de edifícios, salas de teatro, ópera e balé, obtendo maior impacto com a sala inteiramente escura, pois as sombras assumiam configurações espetaculares, resultantes da combinação de luz branca e colorida provenientes das lâmpadas elétricas. Moholy-Nagy teria se inspirado no romantismo alemão para propugnar o conceito de arte total, com a integração de todas as artes, no que chamou de Teatro da Totalidade, em que os efeitos de luz tomariam todo o espaço, projetando-se sobre os atores e o público. Nesse processo, todos os elementos teriam a mesma importância, eliminando as hierarquias e outorgando a substituição dos atores pelo 
movimento dinâmico da projeção, reflexões essas explicitadas no livro Vision in Motion [1947], publicado logo após a morte do artista.

O Modulador tornou a luz matéria escultural e princípio de dissolução da forma, pondo em crise a resistência e a perenidade dos materiais. A luz que emanava do objeto dissolvia a rigidez de suas estruturas metálicas, tornando a matéria translúcida e reverberante, gerando efeitos simultâneos no espaço. O funcionamento do objeto com a utilização de pequeno motor, o aprisionamento de lâmpadas elétricas num compartimento/caixa e a ideia de luz como moduladora do tempo e do espaço pautaram as experiências desenvolvidas cerca de vinte anos depois pelo brasileiro Abraham Palatnik, que certamente conhecia o Modulador, como veremos.

\section{MOLDAR O TEMPO, ORGANIZAR O CAOS, PINTAR COM A LUZ}

Abraham Palatnik [1928-2020], ao retornar de Telaviv [Israel] e se fixar no Rio de Janeiro [1947], era um jovem de dezenove anos, pintor de retratos, naturezas mortas e paisagens de tendência expressionista, como atestam as telas que enviou à Divisão Moderna do Salão Nacional de Belas Artes [1948]. Rapidamente se integrou ao ambiente artístico carioca, aproximando-se de artistas da nova geração, como Almir Mavignier, que o apresentou a Mário Pedrosa. Convidado pelo amigo para conhecer o ateliê de arte do Centro Psiquiátrico D. Pedro II, em Engenho de Dentro [RJ] - atual Instituto Municipal Nise da Silveira -, Palatnik se revelou impactado pelos trabalhos dos alienados, passando a questionar seu próprio processo expressivo. Numa das reuniões na casa de Mario Pedrosa, em que se refletia sobre arte, o crítico sugeriu-Ihe a leitura de livros sobre a Teoria da Gestalt e a realização de pesquisas aplicando os conhecimentos de matemática, física e tecnologia adquiridos em Telaviv. Sem abandonar definitivamente a pintura, o jovem realiza experimentações, visando encontrar novos meios de expressão sem recorrer "à instrumentária clássica, isto é, pincel, tinta, cavalete", como declarou ao jornal Tribuna da Imprensa [1951]. Depois de quase dois anos de tentativas insatisfatórias, Palatnik concluiu um inusitado objeto construído com materiais industriais, que pintava com a luz, concretizando assim um antigo sonho. Tratava-se de uma caixa de madeira, com uma das faces revestida por tecido de nylon, no interior da qual inseriu lentes, cilindros de madeira, com faixas de várias cores, inúmeras lâmpadas elétricas, de diferentes voltagens, conectadas a 600 metros de fio e pequeno motor extraído de um ventilador doméstico, que ligava as lâmpadas e fazia girar os cilindros. A luz que emana 
das lâmpadas incide sobre os carretéis e sobre a superfície refratária das lentes, mudando de direção, o que provoca uma mistura ótica de cores-luz no interior da caixa, que projetada na tela ou écran de nylon sugere uma pintura abstrata mutante, cujo movimento e duração temporal são controlados por contatos elétricos.

O objeto, concluído no início de 1950, é apresentado pelo artista a Mário Pedrosa, que o batizou de Aparelho Cinecromático [PALATNIK, 1951, p. 5]. Fascinado com a invenção, o artista teria declarado ao crítico: "O que o pintor faz com a tinta eu faço com a luz", além de preconizar também a participação público/obra, ideia que, no entanto, parece ter sido também apropriada de Moholy-Nagy. A duração da projeção desse primeiro aparelho foi programada para durar quinze minutos, desligando-se automaticamente ao final do ciclo, cabendo aos espectadores decidirem ligá-lo novamente ou não, para reverem a repetição do evento performático da máquina. Como ocorre no cinema, ao toque do interruptor instalado na lateral externa da caixa, tornava-se possível ligar o Cinecromático e rever a repetição do espetáculo pictórico de formas e cores/luz em movimento, durante o tempo programado pelo artista por meio do pequeno timer, numa alusão ao "eterno retorno". O processo interativo, embora exija algum tipo de ação e reação do interlocutor, não interfere no desempenho da máquina, pois tudo está previamente programado pelo artista. Embora a ideia de participação ou de interação público/obra, tivesse sido preconizada por Moholy-Nagy na década de 1930, difundiu-se apenas na década de 1960, cabendo a Palatnik destacado papel nesse quesito entre sua geração de artistas cinéticos.

Incentivado por Mavignier, o Cinecromático foi enviado pelo autor à I Bienal Internacional de São Paulo, mas por não se enquadrar em nenhuma das tradicionais categorias artísticas previstas no regulamento, o júri, impedido de premiá-lo, sugeriu sua aquisição para o acervo do Museu de Arte Moderna. [PEDROSA, 1975, p. 288-289].

Estranho à crítica, o que explica a escassez de textos referentes à proposta de Palatnik, a maioria ignorou a obra na abertura da Bienal, assunto que discutiremos adiante. Mas chamou atenção dos articulistas da imprensa, que, despreparados para refletir sobre algo inteiramente inusitado no mundo da arte, recorreram ao artista para conceder-Ihes entrevistas e responder às inquirições sobre o Cinecromático.

Em depoimento concedido ao jornal Tribuna da Imprensa [1951, p. 5], Palatnik esclarecia que iniciou a pesquisa almejando "fugir do determinismo 
que padroniza a atividade artística", sem ter ideia precisa de como atingir tal objetivo. Construiu, inicialmente, um caleidoscópio, que observou e manipulou exaustivamente, até se certificar das limitações do objeto para obter algum resultado satisfatório. Destacava, entretanto, que, por sua arbitrariedade, o caleidoscópio o colocou diante de vários problemas, como o jogo combinatório e a questão "estético-perceptiva" do objeto, pois independem do artista:

Cheguei à conclusão de que nem sempre os fatores pessoais vão decidir a estética visual - há outros elementos que participam, por exemplo: certa organização do espaço, as possibilidades da forma e da cor, as proporções em geral etc. Sabemos que é uma esfera ou um quadrado, mas o que necessitamos compreender é a proporção e o significado de tais formas em certa periferia, em certo espaço [PALATNIK, 1951, p. 5]

Afirmava, ainda, que ao pôr o caleidoscópio no espaço: "me deparei com problemas reais: o do movimento, o da ordem e o da cromática luminosa, que consegui [solucionar], depois, através da refração da luz pelo prisma" [PALATNIK, 1951, p. 5].

O objeto cinético dotado de luz/cor em movimento, graças à expertise do artista no emprego de recursos eletromecânicos, demoveu as formas e as cores de sua característica imobilidade e confinamento, para mostrá-las em permanente dissolução, expansão, explosão e transmutação, gerando matizes voláteis de cor-luz se propagando no espaço.

Nos inúmeros Cinecromáticos que o artista elaborou nos anos subsequentes, passou a construir os próprios motores elétricos com dimensões cada vez menores, para obter diferentes efeitos cambiantes e luminosos e uma gama mais variada de cores e formas, que promovem verdadeira dança no écran. Se o resultado final não deixa de remeter, de alguma maneira, à pintura abstrata, por ser gerada com pinceladas de luz e por "outorgar predominância à construção de estruturas em que o exercício da razão se impõe sobre a subjetividade" [BÉRTOLA, 1973, p. 122], se distanciava do processo pictórico convencional. E para além da geração de estímulos visuais e luminocromáticos misteriosos e fascinantes [formas instáveis e jogos cambiantes de cores], a arte cinética propõe "uma relação complexa entre mensagem visual e informação estética" [PIERRE, 2005, p. 27]. 


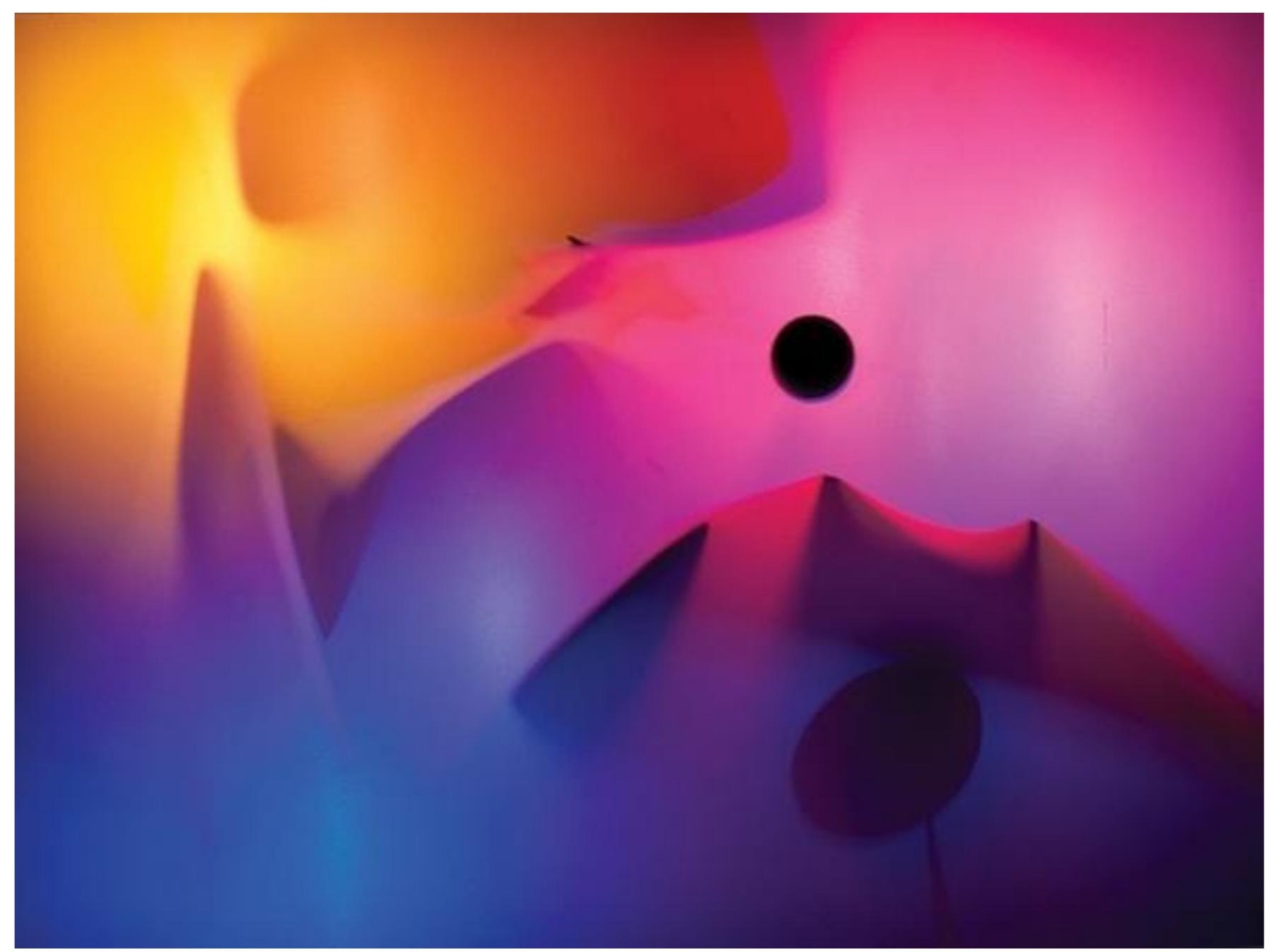

Fig. 1: - Abraham Palatnik. Aparelho Cinecromático, 1955.

[Fonte: Galeria Nara Rosler [SP]] 


\section{DO ESTRANHAMENTO INICIAL À RECEPÇÃO TARDIA DA CRÍTICA}

Se a obra de Palatnik despertou interesse e curiosidade do público visitante da I Bienal, a reação da crítica brasileira seria de perplexidade, não revelando grande entusiasmo ou empatia pelo Cinecromático. Isso explica por que apenas dois críticos mais familiarizados com as novas experimentações se incumbiram de esclarecer sobre as premissas estéticas e o funcionamento do aparelho luminocromático.

Em Introito à Bienal, publicado no jornal Tribuna da Imprensa[1951], Mário Pedrosa referia-se à recusa inicial da obra de Palatnik pelo júri da Bienal e fazia uma série de considerações sobre as experiências pioneiras dos artistas internacionais com a tecnologia e a luz, destacando Moholy-Nagy, cujas experimentações e os estudos da física moderna abriram novos caminhos para a arte. Discorria também sobre a especificidade funcional e estética do Cinecromático, projetando numa tela semitransparente um universo de formas abstratas e cores em movimento aparentemente arbitrário, que remetiam ao caleidoscópio e aos "afrescos de luz" de Moholy-Nagy.

Embora reconhecesse a ousadia e a originalidade do objeto cinético palatnikiano, Pedrosa referia-se à herança do artista húngaro, artista referência tanto para os pioneiros da arte cinética, como para os críticos que dialogaram com ela, o que leva a crer que Palatnik tivesse sido apresentado por Pedrosa à referida obra do artista húngaro:

Abandonando o pincel e o figurativo, decidiu-se [Palatnik], após um estágio abstracionista, a pintar com luz numa audaciosa tentativa de realizar uma das mais velhas "utopias artísticas", na expressão de Moholy-Nagy. [...].

O artista não se pode contentar com o velho métier pictórico, o pincel e as cores químicas pigmentárias. Para controlar, dirigir, plasmar a luz são necessários novos instrumentos e a familiaridade com as conquistas da ótica moderna, desde os problemas de colorometria até as virtualidades da luz artificial.

Palatnik está na linha dos pesquisadores de plástica de luz, isto é, dos efeitos de espaço-tempo sobre nossa sensibilidade. [PEDROSA, 1951, p. 7].

O crítico relacionava as cores da luz que emana do objeto cinético com certos matizes da pintura convencional, mesmo reconhecendo nelas qualidades próprias, o que as diferenciava da gama variada de tons obtidos com pigmentos minerais. Concluía a reflexão observando que, se Moholy-Nagy profetizou que o dinamismo plástico de seus "afrescos de luz iria animar edifícios inteiros ou as paredes das casas do futuro", esse prognóstico se tornou realidade com o advento dos aparelhos domésticos de televisão [PEDROSA, 1951]. 
No artigo A máquina de Abrahão Palatnik, publicado no Diário Carioca, também na inauguração da Bienal [20 de outubro de 1951], Antonio Bento se mostrou bem mais modesto em sua abordagem. Repetindo palavras do próprio artista, o crítico referia-se ao Aparelho Cinecromático "como uma máquina de projeção do tipo suigeneris, o que permitia associá-lo ao cinema, à lanterna mágica e ao caleidoscópio”. E justificava a recusa da obra pelo júri da Bienal, do qual ele foi um dos integrantes, afirmando que a comissão, em mensagem escrita, referia-se ao objeto como "importante manifestação da arte moderna" e considerava-a "digna de figurar no Museu de Arte Moderna de São Paulo", deferência que, segundo o crítico, equiparava-se ao prêmio, pois o objeto acabou adquirido pelo Museu patrocinador do evento.

No texto publicado alguns meses após o encerramento da I Bienal, Uma nova técnica na pintura moderna [1952], Walter Zanini refletia sobre o que chamou de "sentido estético-perceptivo" do objeto palatnikiano, afirmando que ele solucionou o problema da "cromática luminosa", por meio de "um sistema mecânico que transmite a luz movimentando-a na direção desejada". Estabelecia, ainda, analogia entre a pesquisa do artista brasileiro e as proposições dos futuristas italianos, e refletia sobre a contribuição de teóricos como Wertheimer à teoria da Gestalt e à percepção, base da pesquisa desenvolvida por Palatnik, enredamento teórico que atestava a sólida formação intelectual do historiador. Zanini concluía ressaltando o esforço do jovem artista brasileiro em diversificar a experiência estética, ironizando a oposição que Ihe faziam aqueles que, comodamente, não se propunham instaurar nenhum tipo de dúvida, preferindo repetir velhas e gastas formulações pictóricas:

Dá gosto ver um moço como Palatnik buscando, aflito, caminhos novos de expressão nos espaços sidéreos, enquanto os limitados acadêmicos ficam repintando pela multimilionésima vez os seus cachinhos de uva, bem bonitinhos, bem arranjadinhos, bem capazes de dar bom aspecto à casa onde o espírito é eterno ausente. [ZANINI, 1952, p. 6].

Os discursos dos citados críticos não encontraram grande interlocução, nem conseguiram dirimir a aversão ou a dificuldade de compreensão da arte cinética pela crítica conservadora, o que explica a lacuna e a quase completa ausência de reflexões sobre essa vertente artística no período que vai do término da I Bienal até quase o final da década de 1970. Basta citar que a primeira individual de Palatnik, realizada no Museu de Arte Moderna do Rio de Janeiro [1960], angariou a publicação do Jornal do Brasil de uma sequência de notas institucionais não assinadas, cuja função era divulgar a mostra, mas que pouco contribuiriam para alargar a visada cognitiva sobre as obras e a relação entre arte e tecnologia. 
A reflexão mais elucidativa sobre as obras de Palatnik apresentadas nessa exposição viria novamente de artigo de autoria de Mário Pedrosa, Arte e invenção[1960]. Chamava-as de "pintura de luz", geradoras de relações cromáticas que se diferenciavam dos preceitos teóricos e dos resultados pictóricos obtidos com pigmentos. Ressaltava o avanço das pesquisas do artista, por conseguir aperfeiçoar "o mecanismo das projeções", o que permitia iluminar, agora, mais homogeneamente todo o écran. O crítico concluía a reflexão desafiando o artista a diversificar seus inventos, recorrendo a novos dispositivos tecnológicos, embora isso já ocorresse desde o ano anterior:

Quando será que Palatnik, com o gênio inventivo que Deus lhe deu nos trará nova revolução técnica e estética, assenhoreando-se da eletrônica para ganhar melhor liberdade e variação nas suas experiências cinecromáticas? Se já se faz música eletrônica, porque esse talentoso não se decide a palmilhar o terreno inexplorado daquela ciência para criar também a pintura ou o cinecromatismo eletrônico? Já está na hora. [PEDROSA, 1960, p. 6].

O convite para a individual no MAM carioca coincidia com o aumento da circulação internacional da obra de Palatnik por instituições culturais estrangeiras, angariando também notória receptividade e interlocução da crítica. Claramente influenciado pelos escritos de Pedrosa, Jayme Maurício publicava, poucos dias depois da inauguração dessa mostra, na coluna que assinava no Correio da Manhã, denominada Itinerário das Artes Plásticas, uma sequência de tímidas notas sobre as obras expostas, não restritas às propostas cinéticas. Em matéria mais extensa, publicada pouco depois, Palatnik e a Antiteoria do Cinecromatismo [1960], o crítico não parecia devidamente preparado para aprofundar a reflexão sobre as obras. Limitou-se a fornecer informações sobre a formação do expositor e a transcrever trechos de depoimentos do próprio Palatnik a respeito de suas investigações estéticas, com destaque para o conceito de antiteoria. Embora afirmasse concordar apenas parcialmente com a visão do artista, transcreveu no texto o pensamento de Palatnik sobre a questão, sem pontuar em que consistia sua divergência desse conceito:

Antiteoria é a concretização da expressão na obra de arte. É aquilo que realmente se realiza no quadro, na escultura [...]. É aquilo que para ser percebido não precisa ser lembrado, indicado, sugerido, explicado ou teorizado pelo artista ou o crítico. O homem tem que ser estimulado a perceber por conta própria o que existe. O hábito de teorização é negativo, pois o ser inteligente tem habilidade intelectual suficiente para compreender qualquer teoria. Esta compreensão the dá uma segurança e tranquilidade mental tamanha que aceita mesmo as coisas que instintivamente não percebeu por si mesmo [PALATNIK apud MAURÍClO, 1960, p. 2]. 
O crítico francês Michel Ragon, depois de ver as obras cinéticas do brasileiro na VI Bienal de São Paulo [1961], publicou em Paris o texto Le mouvement dans I' art actuel[1962]. Começava por traçar um panorama da evolução e significado da Arte Cinética em todo o mundo, para depois referir-se aos Cinecromáticos de Palatnik como obras que nasceram da mesma vontade que alimentou os quadros luminosos movidos por mecanismos eletrônicos, de autoria de dois reconhecidos expoentes do gênero em todo o mundo: o franco-húngaro Nicolas Schöffer [1912-1992] e o engenheiro americano Frank Malina [1912-1981]. O crítico reconhecia, ainda, que os Aparelhos Cinecromáticos anteciparam em sete anos as experiências luminodinâmicas, apresentadas por Schöffer em Nova York [1957].

Entretanto, nem o aval do teórico francês à ousadia criativa do brasileiro ampliou o interesse da crítica local por suas obras cinéticas que, além de cinecromáticos, exibia na Bienal um naipe mais diversificado de objetos dotados de movimento.

Na França, a Arte Cinética foi exibida e incorporada definitivamente ao vocabulário artístico somente após a exposição Le Mouvement [1955] na Galeria Denise René, em Paris, com curadoria do sueco Pontus Hultén, denominação que rapidamente se universalizou. Nessa mostra, lançou-se um folder, cujos textos se tornaram conhecidos como Mani- festo Jaune. Mas ao apresentar a arte cinética à capital francesa, exibiu-se na mostra tanto obras dotadas de movimento real quanto pinturas óticas de artistas como Victor Vasarely, que apenas sugeriam efeitos dinâmicos.

\section{Como na época os Aparelhos Cinecromáticos de} Abraham Palatnik ainda não haviam circulado no exterior, o artista não integrou a mostra internacional. Apenas em 1966, quando da participação do brasileiro da mostra Kunst-Licht-Kunst, no Museu de Arte de Eindhoven, Holanda, é que, no texto introdutório do catálogo, o conhecido crítico e historiador da arte cinética, o franco-britânico Frank Popper, confirmava o pioneirismo de Palatnik na produção de "móbiles luminosos", posição que reafirmaria no livro Naissance de l'Art Cinetique [1967], incluindo nosso artista no rol dos pesquisadores de "obras luminocinéticas". A deferência ocorreu por o brasileiro participar da 32a Bienal de Veneza [1964] e de outras mostras internacionais, entre elas Le Mouvement II, na citada Galeria Denise René [1964], que teria formulado o convite ao artista depois que a própria galerista viu as obras do brasileiro naquela Bienal.

Repercussão não menos significativa foi o ensaio, de autoria também de Frank Popper, denominado Arte cinética [1968], publicado na revista paulista Artes [n. 15], em que relacionava os estudos da física e da ótica moderna com as novas pesquisas com a 
luz e o movimento. Os textos de autoria dos críticos europeus, decorrentes da ampla circulação da obra de Palatnik por vários países, começariam a romper lentamente a barreira da rejeição aos objetos cinéticos, sendo que o reduto da crítica brasileira ainda não havia se posicionado favorável a esse gênero de trabalhos artísticos. Confirmava, assim, a dificuldade de compreender e dialogar com objetos construídos com materiais industriais e sofisticada tecnologia, que subvertiam o conceito tradicional de escultura e até de obra de arte.

Na década de 1970, quando a Arte Cinética dava sinais de ter cumprido seu ciclo no mundo e a obra de Palatnik já havia transitado por importantes instituições culturais de todos os continentes, continuava despertando pouco interesse no Brasil, posição que se manteve praticamente inalterada até a década seguinte. Curiosamente, apenas em 1977 é que o artista realiza, na Galeria Bonino do Rio de Janeiro, talvez sua mais significativa exposição comercial, sendo que a crítica praticamente a ignorou. Coube a Roberto Pontual publicar no Jornal do Brasil[1977] o texto mais elucidativo sobre a exposição, embora a reflexão se respaldasse em falas do artista. $\bigcirc$ crítico iniciava o discurso destacando a importância da mostra, cujo artista não lhe era inteiramente desconhecido:

Se me perguntasse que retrospectiva de artistas brasileiros julgo de realização mais urgente e oportuna, neste momento, eu não relutaria em colocar entre elas a de Abraham Palatnik. [...]. A certeza da necessidade de abordar e compreender panoramicamente a obra de Palatnik não é, para mim, coisa de hoje; veio-me desde que o visitei pela primeira vez no seu apartamento de Botafogo, em 1972 [PONTUAL, 1977].

Entretanto, logo em seguida fazia uma espécie de mea culpa, ao afirmar que a atenção sobre a exposição foi despertada por carta que Ihe enviou de Hamburgo Almir Mavignier, ressaltando o significado da obra e da trajetória de Palatnik, entre outros aspectos, como o de ser ele

[...] um dos primeiros brasileiros dispostos a absorver a rigorosa disciplina da linguagem construtivista entre nós, ao fim da década de 40. Esta menção e a presença da individual de Palatnik, atualmente na Galeria Bonino, do Rio, indicam os marcos extremos, até aqui, de uma carreira e de uma obra que o público precisa ver e conhecer meIhor [PONTUAL, 1977].

Apenas da década de 1980 até o início deste século é que a produção de Palatnik - em seus diferentes suportes e modalidades - passou a angariar maior espaço na mídia e nas instituições culturais brasileiras. Entretanto, sua obra ainda é pouco conhecida e estudada, sem contar que não se publicou, até então, um estudo acadêmico refletindo exclusivamente sobre sua produção cinética. Assim, este texto presta tributo ao artista, falecido em 2020, vítima de Covid-19. Revista Poiésis, Niterói, v. 23, n. 39, p. 170-186, jan./jun. 2022. [DOl: https://doi.org/10.22409/poiesis.v23i39.50822] 
BARRET, Cyril. A Arte Cinética. In STANGOS, Nikos. Conceitos de Arte Moderna. Tradução de Álvaro Cabral. Rio de Janeiro: Jorge Zahar, 1991, p. 150-159.

BENTO, Antonio. A Máquina de Abrahão Palatnik. Diário Carioca, Rio de Janeiro, 20 de outubro de 1951, p. 6.

BÉRTOLA, Elena de. Arte Cinético. Em movimento y la transformatión: análisis perceptivo y funcional. Buenos Aires: Nueva Visión, 1973.

BIHALI-MERIN, Oto. La fin de l'Art à l'ère de la Science? Bruxelas: La Conaissance, 1970.

MAURíCIO, Jayme. Palatnik e a "Antiteoria" do Cinecromatismo. Correio da Manhã, Rio de Janeiro, 11 de abril de 1960 , p. 2 (2․ Caderno).

PALATNIK, Abraham. Na I Bienal: a magia de Palatnik. Luz no lugar da tinta (depoimento). Tribuna da Imprensa, Rio de Janeiro, 5 de novembro de 1951, p. 5.

PARENTE, André (org). Imagem Máquina. Rio de Janeiro: Edições 34, 1993.

PEDROSA, Mário. Arte e Invenção. Jornal do Brasil, Rio de Janeiro, 23 de março de 1960, p. 6 (1 o Caderno). 
PEDROSA, Mário. Introito à Bienal. Tribuna da Imprensa, Rio de Janeiro, 20 de outubro de 1951, p. 7.

PedrosA, Mário; AMARAL, Aracy, (org.). Mundo, Homem, Arte em crise. São Paulo: Perspectiva, 1975.

PIERRE, Arnauld. L'Oeil Multiplié. In L'Oeil Moteur: art optique et cinétique, 1950-1975. Estrasburgo: Les Musées de Strasbourg, 2005, p. 20-29.

PONTUAL, Roberto. Movimento: do motor, do olho, da gente. Jornal do Brasil, Rio de Janeiro, 14 de maio de 1977, p. 4 (Caderno B).

POPPER, Frank. Naissance de I’Art Cinetique. Paris: Gauthier-Villards, 1967.

RAGON, Michel. Le mouvement dans I' art actuel, Jardin des Arts, Paris, n. 95, outubro de 1962. p. 54-61.

TOMKINS, Calvin. Duchamp. Tradução de Maria Thereza R. Costa. São Paulo: Cosac Naify, 2004.

ZANINI, Walter. Uma nova técnica na pintura moderna. O Tempo, São Paulo, 1 de junho de 1952. 


\section{IMAGENS EM TRÂNSITO, PODERES E ARQUIVOS'}

Images in transit, powers and archives

Imágenes en tránsito, poderes y archivos

$>$ Maria Ilda Trigo [Universidade Estadual de Campinas, Brasil]

Fernanda de Souza Oliveira [Universidade Estadual de Campinas, Brasil]* *

RESUMO Este artigo visa à elaboração de um ensaio crítico às imagens e aos espaços de poder em que circulam, a partir do recorte de nossas pesquisas sobre os arquivos de fotografias pessoais. Apoiando-se na noção de visibilidade elaborada pela filósofa argelina Marie-José Mondzain, que destaca a vocação para o trânsito e as relações com o poder como características fundamentais das imagens. Tratamos no texto das consequências dessa relação, que incluem o controle de visibilidades, e que serão levadas em consideração para a análise do objeto de nossas pesquisas: o arquivo, incluindo um arquivo de fotografias de família, por um lado, e arquivos de imagens digitais feitas com celular, por outro. PALAVRAS-CHAVE Imagens; poder; fotografia; arquivos pessoais.

ABSTRACT This article intend to elaborate a critical essay on the images and power spaces in which they circulate, from the clipping of our research on the archives of personal photographs. Relying on the notion of visibility elaborated by the Algerian philosopher Marie-José Mondzain, who highlights the vocation for traffic and relations with power as fundamental characteristics of images. We deal in the text of the consequences of this relationship, which include visibility control, and which will be taken into account for the analysis of the object of our research: the file, including a file of family photographs, on the one hand, and digital image files made with mobile phone on the other.

KEYWORDS Images; power; photography; personal archives.

* Maria lldo Trigo é Pesquisadora do Programa de Pós-Graduação em Artes da Universidade Estadual de Campinas.

E-mail: ildatrigo@hotmail.com. Orcid: https:/ / orcid.org/0000-0002-4014-9630

* * Fernanda Oliveira é Pesquisadora do Programa de Pós-Graduação em Artes da Universidade Estadual de Campinas.

E-mail: fefe_so@hotmail.com. Orcid: https:/ / orcid.org/0000-0003-4275- 1139

Revista Poiésis, Niterói, v. 23, n. 39, p. 187-204, jan./jun. 2022. [DOl: hitps://doi.org/10.22409/poiesis.v23i39.49002] 
TRIGO, Maria Ildo; OLIVEIRA, Fernanda de Souza. Imagens em trânsito, poderes e arquivos. Revista Poiésis, Niterói, v. 23, n. 39, p. 187-204, jan./jun. 2022.[DOI: https:// doi.org/10.22409/ poiesis.v23i39.49002]

Este documento é distribuído nos termos da licença Creative Commons Atribuição - Não Comercial 4.0 Internacional (CC-BYNC) (c) 2022

Maria lldo Trigo, Fernanda de Souza Oliveira. Submetido: 5/3/2021; Aceito: $25 / 5 / 2021$
RESUMEN Este artículo tiene como objetivo elaborar un ensayo crítico sobre las imágenes y espacios de poder en que circulan, a partir del recorte de nuestra investigación sobre los archivos de fotografías personales. Basándose en la noción de visibilidad elaborada por la filósofa argelina Marie-José Mondzain, quien destaca la vocación de tráfico y las relaciones con el poder como características fundamentales de las imágenes. Abordamos en el texto las consecuencias de esta relación, que incluyen el control de visibilidad, y que serán tenidas en cuenta para el análisis del objeto de nuestra investigación: el archivo, incluyendo un archivo de fotografías familiares, por un lado, y los archivos de imagen digital realizados con teléfono celular por otro.

PALAVRAS CLAVE Imágenes; poder; fotografía; archivos personales. 
INTRODUÇÃO: IMAGENS EM TRÂNSITO

A intensa presença das imagens na vida cotidiana, bem como as implicações dessa presença, faz com que pensar sobre elas na contemporaneidade implique considerar uma série de autores para os quais imagem rima com complexidade. Embora esses autores sejam muitos - e muitas vezes contradigam-se - o fato de que imagens não são objetos pacíficos tem sido a base sobre a qual se desenvolve a maior parte dos pensamentos teóricos sobre elas em ambiente acadêmico. E é também o ponto de partida deste artigo.

Nó em redes, centro de forças, agenciadoras de relações [MONDZAIN in: ALLOA, 2017, p. 39], imagens não são objetos fechados, e sua interpretação e compreensão não podem desconsiderar esse fato. Em outras palavras, não podem ser igualmente "fechadas", definitivas, tampouco necessariamente concordantes.

Isso impõe a quem deseje considerar essa complexidade intrínseca delimitar o campo de alcance do pensamento a ser formulado, o que aqui se fará pela eleição de um conjunto de autores cujas formulações, a nosso ver, ajudam-nos a compreender de forma crítica - e igualmente fecunda - o objeto de nossas pesquisas: os arquivos de fotografias pessoais.
Para lidar com essa complexidade, escolhemos a construção de saberes sobre as imagens da filósofa Marie-José Mondzain, por concordar com seu caminho de leitura, que percebe, na construção histórica das visualidades, a imagem como tendo uma vida ou poder próprios, construídos num movimento de dar a ver, "Pois a imagem não existe senão no fio dos gestos e das palavras, tanto daqueles que a qualificam e a constroem, como daqueles que a desqualificam e a destroem" [MONDZAIN, 2009, p.12]. Em outras palavras, trata-se da imagem como portadora de uma singularidade que é ativada pelo olhar do espectador: é esse gesto de olhar que ativa o poder das imagens.

As reflexões da autora são a espinha dorsal deste texto, que se insere nas discussões sobre uma possível vida ou poder próprio das imagens, destacando que essas estão sempre entre eventos: aquele que marca sua causa [proveniência] e aqueles de suas destinações, aos quais podemos relacionar os modos como se processam suas visibilidades. Aqui, subentende-se que conhecer uma imagem significa, necessariamente, [re]conhecer sua história e sua vocação para o "trânsito"2 É nesse trânsito - e apenas nele-que a imagem se constitui e nos constitui, instaurando e agenciando subjetividades cujo controle foi almejado pelas mais diversas instituições nos diferentes tempos históricos. 
A compreensão de imagem no trânsito entre sujeitos e instituições possibilita uma abordagem profundamente política de seus estatutos: ela passa a ser considerada por seu poder formador, como prática social, e seus estatutos são incorporados pelos poderes instituídos, o que inclui os discursos históricos em relação a elas.

\section{PROVENIÊNCIA E DESTINAÇÃO}

Nos caminhos percorridos por qualquer imagem, Marie-José Mondzain aponta duas direções: aquela de onde a imagem provém [sua proveniência ou origem] e a[s] de sua[s] destinações, o que implica, segundo a autora, inscrever a imagem "em uma trajetória que visa uma gênese [...] e uma visada sobre seu desdobramento" no tempo-espaço, com as consequentes marcas de historicidade [MONDZAIN, in ALLOA, 2017, p. 40].

Mas interrogar-se sobre o "lugar" onde a imagem surge e os possíveis caminhos por ela percorridos não pode se limitar a uma narrativa que vise à restauração ou recuperação mais ou menos plausível ou linear da vida "visível" deste "objeto" - o que parece ter sido a tarefa da História da Arte em geral. Atentar para a imagem em trânsito implica, primeiramente, interrogar-se sobre sua "natureza" e seu papel na "genealogia do huma- no", da qual ela é indissociável [MONDZAIN, in ALLOA, 2017, p. 40].

Para a autora, é impossível desvincular a história das imagens da história dos sujeitos, ou da instauração de "regimes de subjetividade" [MONDZAIN, in ALLOA, 2017, p. 40]. Em entrevista concedida a Michaela Fiserova, Mondzain afirma: "imagem [é] o modo de aparição frágil de uma aparência constituinte para olhares subjetivos, em uma subjetivação do olhar. A imagem é efetivamente, no meu léxico, o que constitui o sujeito" [MONDZAIN, 2008, p.180]. Em seu livro homo spectator: ver > fazer ver, Marie-José simplifica ainda mais esse entendimento, afirmando que "pode ainda dar-se o nome imagem a tudo o que faz de um sujeito que vê um sujeito capaz de estabelecer com o visível uma relação de espectador" [MONDZAIN, 2015, p.18] .

Imagem e sujeito estão totalmente imbricados, e essa relação está na gênese das "operações imaginantes" [MONDZAIN, in ALLOA, 2017, p. 41]. Mondzain esclarece essa relação com um exemplo paradigmático, que ela considera como o primeiro gesto de autorrepresentação: a impressão negativa de uma mão na Gruta Chauvet [figura 1]. 
Imaginando, sem anseio de um reencontro com o arcaico, o acontecimento desse gesto de autorrepresentar-se, a autora considera a produção de imagens [e em especial desta] como a instauração de diferenças, de separações. Segundo ela:

A imagem de si é uma prova da separação, a instauração de um regime de separação e de uma subjetividade desatada. Quando esse sujeito se engaja no caminho imaginante que o subtrai da necessidade natural, ele inaugura um regime de liberdade que não será aceito, sem controle, tanto pela vontade instituinte quanto pelos poderes instituídos. [MONDZAIN, in ALLOA, 2017, p. 42

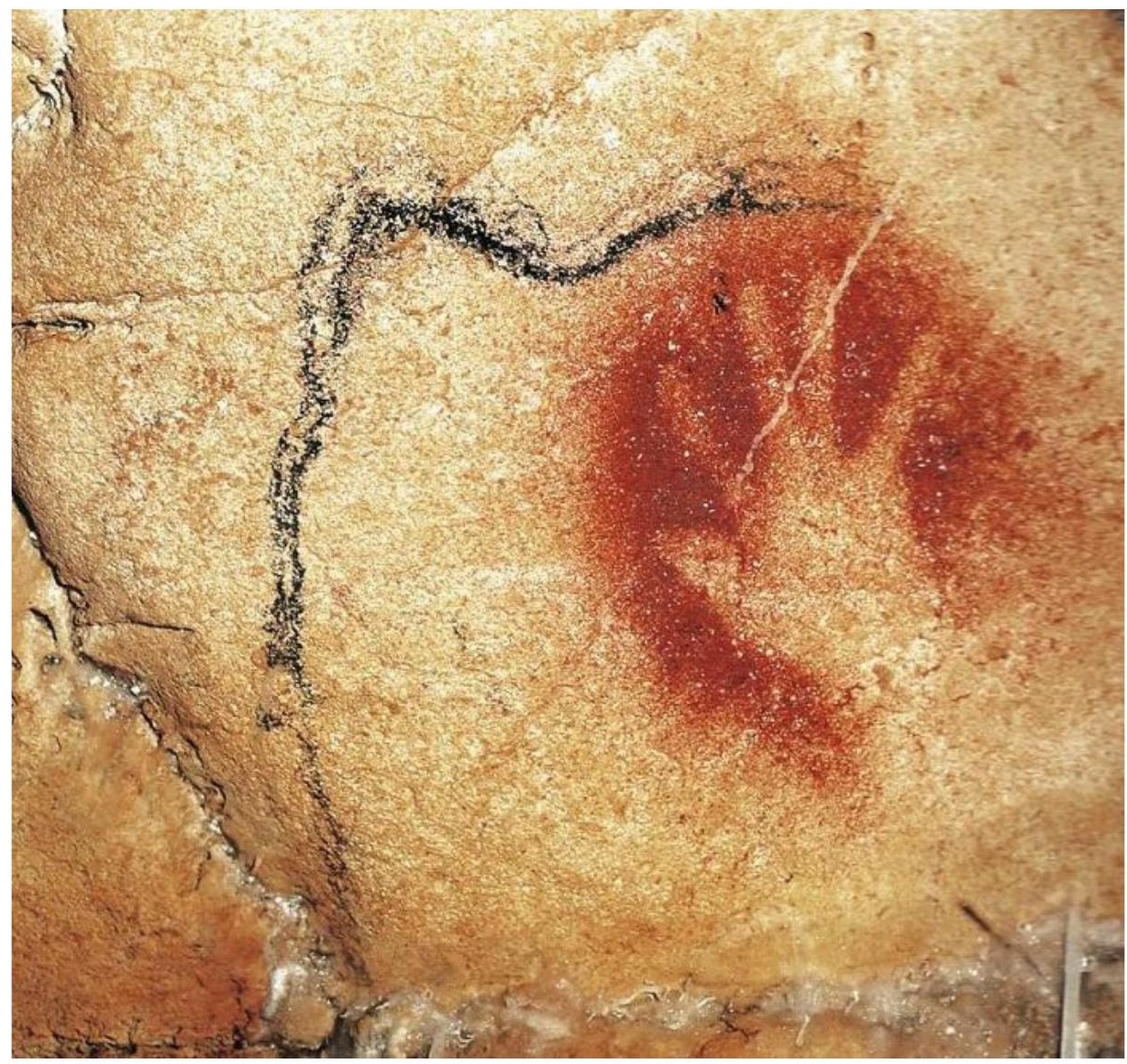

Assim, imagens proveriam do gesto emancipatório de Fig. 1: Impressão em negativo na Gruta Chauvet [França], 30.000 a. C. Fonte: ALLOA, Emannuel [org.]. Pensar a imagem. Belo Horizonte: Autêntica, 2017, p. 43. representar e, especialmente, de representar a si próprio. E sua destinação "originária" seria "romper com toda origem" [MONDZAIN, in ALLOA, 2017, p. 44], gerando autonomias - ou a capacidade de enxergar-se separado de uma origem, seja ela a natureza ou uma instituição. Esse seria o poder primeiro do gesto gerador

de imagens. Essa potência primeira é altamente ameaçadora às instituições. Assim, não é de se espantar que "[...] a proveniência das operações imaginantes [esteja] na origem do problema político que coloca sua destinação" [MONDZAIN, in ALLOA, 2017, p. 41]. 
Dito de outra forma, por gerar separações/autonomias, as imagens seriam uma constante ameaça ao que está instituído como "ordem" [seja ela natural ou não]. Em sua produção - e quiçá em sua recepção - residiria sempre a possibilidade de um "levante", de uma tomada de consciência que torna suas destinações alvo de controle, com a criação de visibilidades controladas. Trata-se aqui de visibilidade pelo ponto de vista de Marie-José "como o modo no qual aparecem no campo do visível objetos que ainda esperam sua qualificação por um olhar" [MONDZAIN, 2008, p.180]. E é daí que vem a necessidade de controle e a ameaça: o poder está no olhar de quem qualifica as imagens.

\section{PODER IMAGÉTICO E PODERES INSTITUÍDOS}

Estamos tratando, portanto, do poder em dois níveis: o que é próprio da imagem [geração de autonomias/separações] e o das instituições, que pretendem controlar o poder daquelas para manter o próprio.

A discussão sobre o lugar das imagens nas religiões monoteístas e na metafísica clássica, predominantemente iconofóbicas, são para a autora o maior exemplo dos perigos representados pelas imagens para as instituições. Controlar esses perigos implica uma série de decisões e imposições, que vão desde a simples proibição [no caso, por exemplo, do judaísmo], ou a elaboração de um estatuto de subalternidade, [no caso da metafísica clássica], até o "deslocamento" promovido pelo cristianismo, que institui uma "visibilidade redimida e salvadora", baseada no "devir-imagem da divindade" [MONDZAIN in ALLOA, 2017, p. 45].

De qualquer modo, interferindo-se em sua proveniência [no caso dos proibicionismos] ou em suas destinações [no caso do controle de visibilidades], pretende-se cortar o fio tênue e indeterminado que pode unir, de súbito, dois [ou mais] sujeitos, pela potência de um endereçamento inerente à imagem. Em sua vocação para o trânsito, ela pode colocar em relação, agenciar subjetividades desejantes, pôr em jogo a partilha do comum.

Assim, nota-se que, principalmente no monoteísmo, a preocupação com as imagens revela uma outra: a preocupação com os sujeitos das imagens [MONDZAIN in ALLOA, 2017, p. 44], tanto daqueles que "habitam" sua proveniência quanto daqueles que podem vir a ocupar o tempo-espaço de suas destinações. É, portanto, contra a possibilidade de instauração de subjetividades compartilhadas que se insurgem os poderes instituídos. Eles pretendem impedir que "[...] as imagens [venham] se colocar entre os sujeitos que não se definem como tal senão pela graça desses signos que vêm [...] dançar entre eles" [MONDZAIN in ALLOA, 2017, p. 48]. 
Marie-José exemplifica os efeitos das imagens na organização da vida em sociedade, com a grande crise identitária causada pela intensa proliferação de imagens, cujo resultado mais direto seria o colapso de identidade que ela gera. Nesse caso, a dificuldade de o sujeito se entender e se projetar como imagem, num mundo altamente imagético, traz profundas crises de identidade. De acordo com a autora: sam nos arquivos, pontuamos nossa relação com eles nesse texto, pelo entendimento de arquivos como a combinação de práticas sociais e também pela noção teórica de dispositivo. A ideia nos é apresentada pelo historiador Santiago Júnior em seu artigo "Dimensões historiográficas da virada visual ou o que pode fazer o historiador quando faz histórias com imagens?", publicado na revista Tempo e Argumento [2019]. Para ele:
Assim como a imagem foi verdadeiramente uma grande aposta no momento da guerra iconoclasta, também a gestão industrial do espetáculo coloca-se como pano de fundo aos verdadeiros contextos do conflito. [MONDZAIN, 2008, p. 187]

Numa época em que o super compartilhamento de imagens parece transformar todos os sujeitos em espectador, o poder inerente às visibilidades foi absorvido pelo capital, em sua busca por um esvaziamento crítico das imagens, e foi direcionado para propósitos de consumo. Nesse caso a imagem que o sujeito espectador tem de si é construída por meio da aquisição de produtos e da reprodução de estilos vendidos imageticamente como necessários para a inserção social.

\section{ARQUIVO E DISPOSITIVO}

Antes de procedermos à reflexão sobre de que maneira as relações entre imagem e poder se proces-
A análise do dispositivo implica o estudo das condições de possibilidades da construção de conhecimento [saberes] e sujeitos em uma dada situação histórica, uma vez que é uma forma concreta que mobiliza discursos e práticas na constituição do conhecimento e informação que circulam socialmente. $\bigcirc$ estudo histórico dos dispositivos é uma tentativa de construir a estratificação dos saberes e práticas sociais que tornaram possível que um dado conjunto de sujeitos se relacionasse com um dado conjunto de representações por meio de máquinas que transformam pessoas em espectadores. [JUNIOR, 2019, p.423]

Mondzain, por sua vez, trata os dispositivos como "objectos eficazes numa operação simbólica de transferência, é através da imagem, fac-similada ou objecto substitutivo, que uma relação de poder se estabelece" [MONDZAIN, 2009, p.22]. Donde se pode concluir que a imagem-arquivo tem poderes: aqueles que the são próprios, por ser imagem; e aqueles que lhe empresta o fato de fazerem parte de um dispositivo. 
Assim, concebendo os arquivos como dispositivos e, portanto, eficazes em sua tarefa de validar determinada prática social, pretendemos questionar como se opera, neles, a instituição de visibilidades controladas, em que se impõem os gestos do capital [portador do poder] ao espectador [convertido em receptor passivo].

\section{ARQUIVO E PODERES}

Por uma característica muito especial de nosso tempo, que parece padecer de uma "mania arquivística" [COLOMBO, 1991, p. 17], ou de um "mal de arquivo" [DERRIDA, 2001, p. 9], a importância dos arquivos e a necessidade de sua preservação têm sido pauta de muitos debates. Com razão, reivindica-se o direito aos arquivos, muitas vezes negligenciados por governos que não têm interesse em garantir sua preservação e o acesso a eles.

É certo que temos que lutar pelos arquivos. Mas é certo também que devemos enxergá-los não como mero repositório de "acontecimentos", dos quais os elementos arquivados seriam indício, e sim como complicação. Em outras palavras, faz-se necessário pensar nas potências que Ihes são inerentes e, mais que tudo, nas forças que eles agenciam, nos desejos que mobilizam sua criação e sua fruição.
Essa visada não ingênua sobre os arquivos, defendida por muitos autores, inclusive os acima citados, implica refletir sobre sua relação com o poder estabelecido, ou melhor, sobre como sua criação é instrumento para constituir e perpetuar instituições que podem vir a tornar-se hegemônicas, "pois todo arquivo [...] é ao mesmo tempo instituidor e conservador" [DERRIDA, 2001, p. 17].

Para alcançar esse intento primeiro [instituir e conservar], há muitas estratégias, dentre as quais o controle das visibilidades.

Arquivos tiram do fluxo. Invisibilizam temporariamente aquilo que, no caso das imagens, estaria fadado à perda, principalmente considerando-se a realidade atual, em que grandes velocidade e volume marcam o processo de produção, reprodução e circulação de imagens.

Tirar do fluxo significa aqui retirar indícios de uma vida - alguma possibilidade de memória - em meio ao caos muitas vezes programado de informações/ imagens circulantes. O que é louvável. E sobretudo necessário. Mas é também impor uma segunda destinação à destinação primeira de toda imagem que é, como já dissemos, estar em trânsito.

Essa vida fora do fluxo é extremamente controlada, ordenada conforme desejos e interesses daquele a quem coube o lugar arcôntico ${ }^{3}$, ou seja, a quem 
coube instituir as normas. $\bigcirc$ arquivo "guarda, põe em reserva, economiza, mas de modo não natural, isto é, fazendo a lei [nomos], ou fazendo respeitar a lei." [DERRIDA, 2001, p. 17].

Esta seria a destinação imposta pelo arquivo às imagens que ele mesmo salvou de se perderem: contar a história, do ponto de vista de quem o constituiu. Donde se pode concluir que quem arquiva tem a primazia da História.

ARQUIVOS DE FOTOGRAFIA DE FAMÍLIA [ANALÓGICOS]

Pensar em como - e com que intenção esse controle de visibilidades se realiza nos arquivos de fotografias de família [analógicos] implica frisar dois de aspectos fundantes: o primeiro é o fato de ser predominantemente
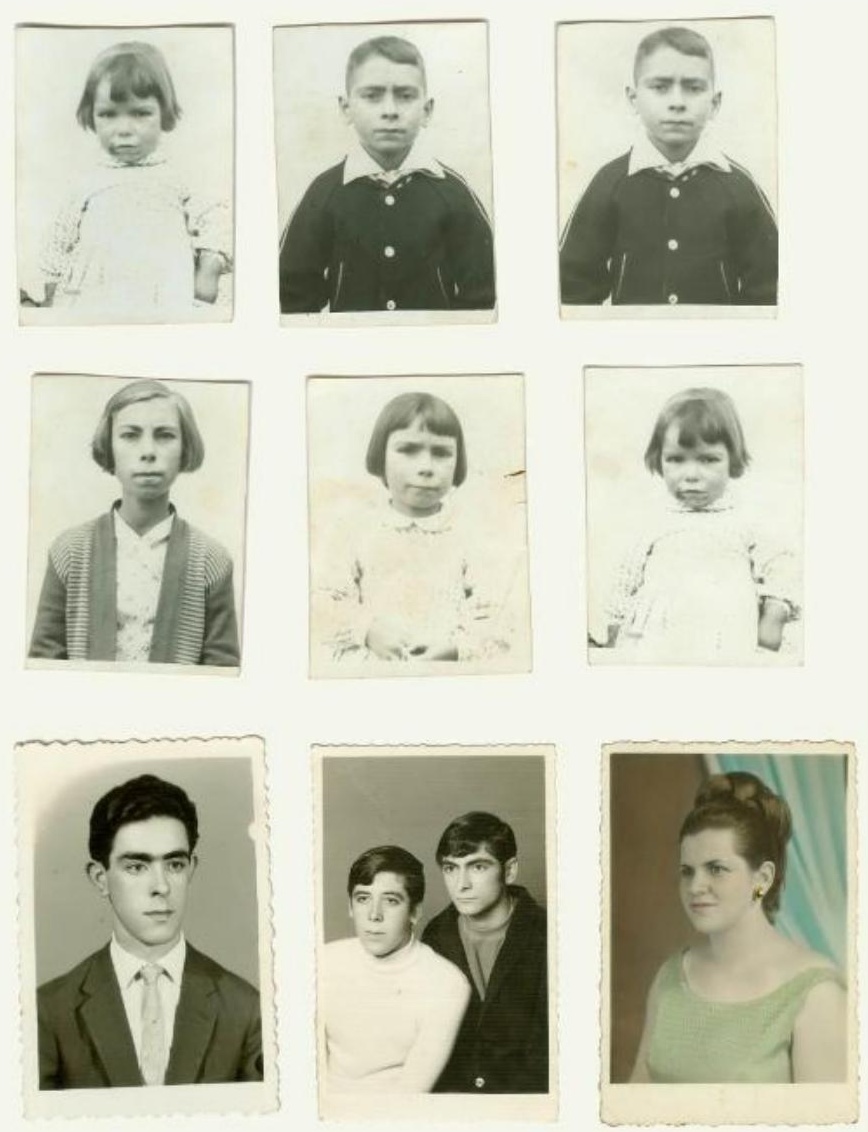

Fig. 2: Fotografias que compõem o acervo sobre o qual se baseia uma das pesquisas tratadas neste ensaio, $20 \mathrm{~cm} \times 16 \mathrm{~cm}$, décadas de 1950 e 1960 . Fonte: Acervo pessoal. fotográfico ${ }^{4}[$ e, no caso estudado, também analógico]; o segundo, que diz respeito à instituição que ele ajuda a formar, é o fato de ser "de família".

Que instituição é essa que guarda cuidadosamente em seu seio um arquivo? Por mais ingênuo e simples que possa parecer, um arquivo de família guarda todas as propriedades de outros mais oficiais e complexos: ele também conta uma história. História essa que, tanto quanto outras, faz-se de ditos e interditos. Ou seja: ele dá visibilidade a eventos que se desejam de família. Lá reside a história que se quer lançar para as futuras gerações: a narrativa oficial da família, cujas tristezas, não necessariamente visibilizadas em seu arquivo, não podem ser senão adivinhadas.

Contribui para isso a própria "natureza" do arquivo, que é, antes de qualquer outra coisa, a "[...] consti- 
tuição de uma instância e de um lugar de autoridade" [DERRIDA, 2001, p. 11]. Por mais modesto que seja, ele "[...] tem força de lei, de uma lei que é a da casa [ôikos], da casa como lugar, domicílio, família ou instituição" [DERRIDA, 2001, pp. 17-18].

Se a natureza-artifício dos arquivos possibilita como talvez nenhum outro dispositivo a instituição de um discurso de família, pretensamente original e originário, o fato de ele se constituir predominantemente de fotografias apenas reforça a potência da narrativa construída.

O caráter indicial da fotografia, apesar de sistematicamente questionado por pensadores e teóricos, ainda vigora na experiência de fruição fotográfica, principalmente daquela que se efetiva em nossas atividades cotidianas, marcadas mais pelo afeto do que pela reflexão. Naqueles pedaços de papel insinuam-se instantes perdidos. Instantes realmente vividos?

Mas uma visada que deseje compreender o arquivo em sua complexidade, e não apenas referendar sua indicialidade, não pode desconsiderar que:
Isso nos faz pensar o quanto os arquivos de família não estão, apesar de sua aparente despretensão, investidos de uma força documental que o eleva à categoria de monumento, de um "poder de perpetuação" [LE GOFF, 2013, p. 486] que deita suas bases sobre o "[...] esforço [...] para impor ao futuro - voluntária ou involuntariamente - determinada imagem de si [...]" [LE GOFF, 2013, p. 497].

Aqui cabe ainda uma consideração sobre o fato de que, no caso, trata-se de fotografias analógicas, com todas as implicações formativas e performativas disso, que não nos cabe aqui analisar em profundidade. Apenas chamamos a atenção para o fato de que tanto a produção das fotografias quanto do arquivo em si inserem-se numa prática social de mercado, de produção e comercialização massiva, o que dá a ela contornos sui generis: a de construção de uma visibilidade de família pretensamente singular e única, a partir de uma materialidade padronizada, à qual corresponde não apenas uma fisicidade objetual obrigatória, mas repertórios de gestos e padrões do bem fotografar, como se pode perceber na contracapa de um álbum que contém conselhos para a obtenção de boas fotos. [figura 3].
A fotografia não documenta o cotidiano. Ela faz parte do imaginário e cumpre funções de revelação e ocultação na vida cotidiana. Portanto, as pessoas são fotografadas representando-se na sociedade e representando-se para a sociedade. A fotografia documenta, como atriz, a sociabilidade como dramaturgia. Ela é parte da encenação. Ela reforça a teatralidade, as ocultações, os fingimentos. Traz dignidade à falta de dignidade, ao simplismo repetitivo da vida cotidiana. [MARTINS, 2008, p. 47] 


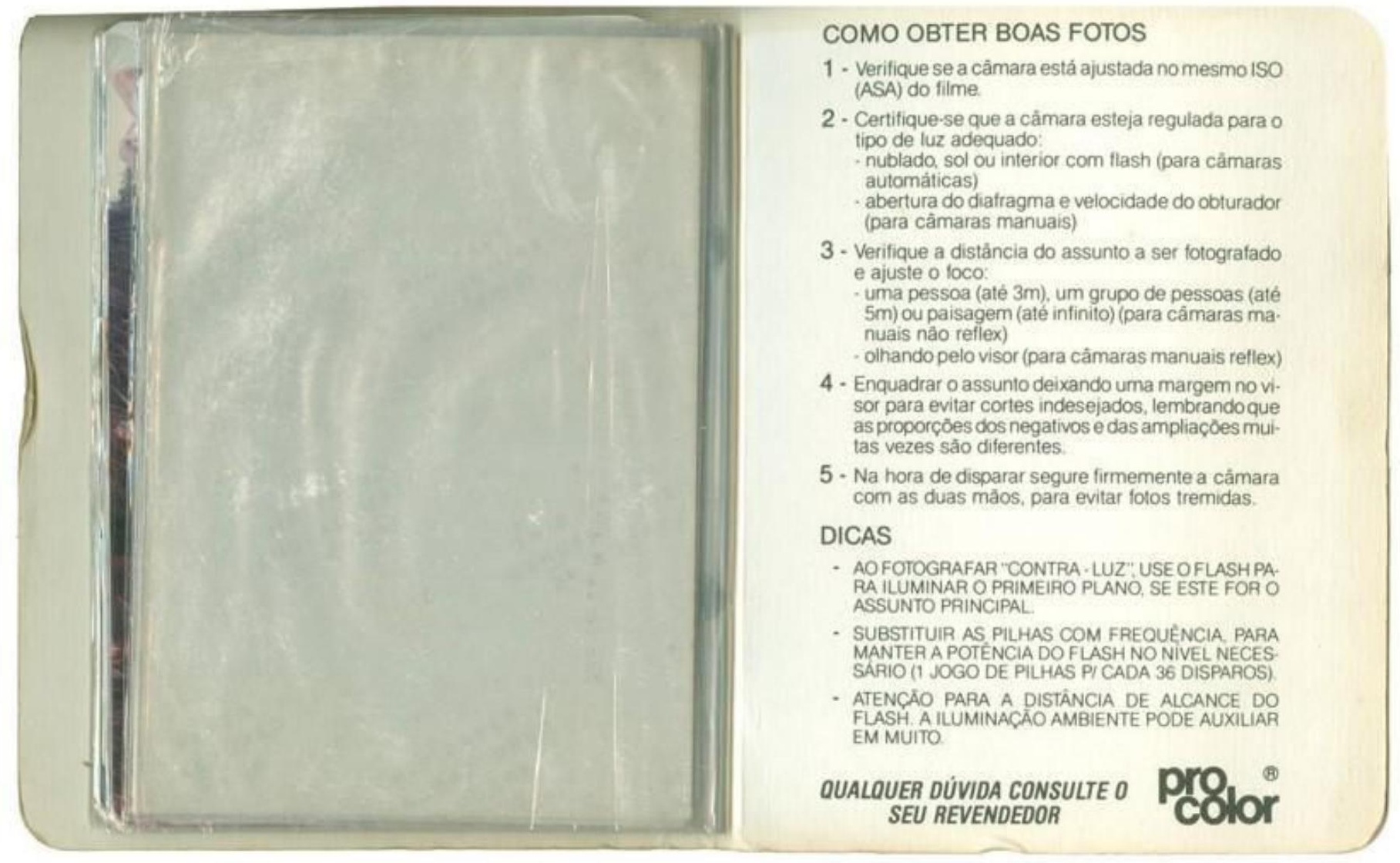

Fig. 3: verso de álbum de fotografias, 23,5 cm X $16 \mathrm{~cm}$ [aberto], c. 1985. Fonte: Acervo pessoal.

\section{ARQUIVOS DE FOTOGRAFIAS DIGITAIS}

Quando mudamos o foco de análise para os arquivos digitais, deve-se enfatizar o contexto em que esses surgem: o de predomínio de imagens, que se constituem em importante instrumento de comunicação. Em consequência das tecnologias emergentes, as pessoas estão cada dia mais se comunicando por imagens, fenômeno ao mesmo tempo estimulado e incorporado pelo sistema do capital e pelas grandes empresas de tecnologia, que não cessam de ofertar meios para a produção e Revista Poiésis, Niterói, v. 23, n. 39, p. 187-204, jan./jun. 2022. [DOl: https://doi.org/10.22409/poiesis.v23i39.49002] 
disseminação de imagens pelo cidadão comum. Os celulares, por exemplo, oferecem como diferencial de mercado as facilidades de acesso à câmera, e os aparelhos disputam entre si qual produz imagens com melhor qualidade, de processamento mais rápido e compartilhamento quase imediato.

O celular como principal dispositivo de comunicação, por seu caráter instantâneo e de conexão direta às redes sociais e online, gera uma tensão entre o espaço físico e o digital, os mundos on-line e off-line, aumentando a produção e o compartiIhamento de imagens em um fluxo hiper-acelerado. $\mathrm{O}$ artista e pesquisador Joan Fontcuberta, em seu livro A câmera de Pandora: a fotografi@depois da fotografia, nos mostra que essa tensão é a resposta à economia que lida com a informação como mercadoria, em que a regra é a velocidade e o imediatismo. Ele afirma:

Essa evolução tecnológica e as consequências nos hábitos da sociedade contemporânea favoreceram a noção de fotografia como captação de um instante. A necessidade de capturar tudo é acentuada. Tudo é fotografável e, além do mais, tudo é mostrável. [FONTCUBERTA,2012, p.32]

Respondendo a esse hábito de imediatismo, o celular converteu as pessoas, que a ele têm acesso, bem como às redes móveis, em produtoras de ima- gens, fenômeno mediador das experiências estéticas contemporâneas. Pode-se dizer que a imagem hoje é um dispositivo de mediação, e que a necessidade de interação por meio do dispositivo se tornou indispensável. Segundo Giselle Beiguelman:

Há uma inequívoca compulsão pelo arquivamento hoje. E esse arquivamento é mobilizado pela possibilidade de publicação das informações nos canais mais diversos das redes. Registra-se tudo no afã de marcar um momento. [BEIGUELMAN, 2018]

Esse aspecto de comunicação imediata apresentado pela tecnologia digital cria uma nova lógica de poder entre os agenciamentos de visibilidades das imagens. Para existir no ambiente online, as imagens precisam ser compartilhadas, acessadas e curtidas; antes disso elas existem sob um estado de invisibilidade, uma espécie de latência ${ }^{5}$ criada por essa existência em rede, como sintetiza o professor e pesquisador de fotografia Rubens Fernandes:

O avanço tecnológico foi dotando a humanidade de artefatos que ampliaram significativamente a possibilidade receptiva, mas ao mesmo tempo, notamos o aparecimento de mediações cada vez mais complexas entre os homens, e entre estes e a realidade. [...] Hoje, as imagens se propagam com tal velocidade que, em questão de minutos entre o fazer e disponibilizar, curtir e compartilhar, tornam-se irrelevantes, ou seja, invisiveis, descartáveis. [FERNANDES JÚNIOR, 2012]. 




Fig. 4: Celulares em Hong Kong durante protestos, 2014

Fonte: Wikimedia Commons 


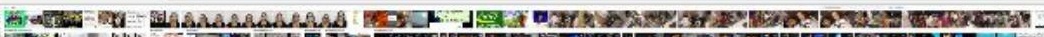



Ti:-

1.

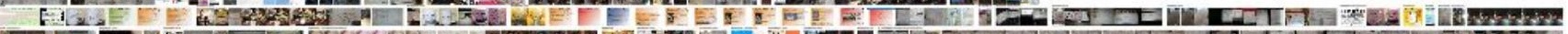

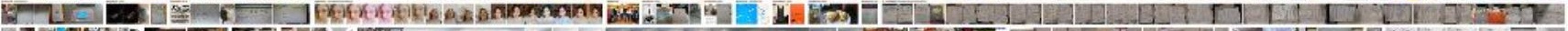



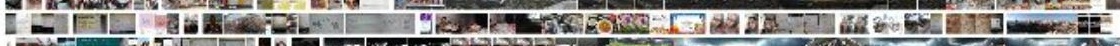

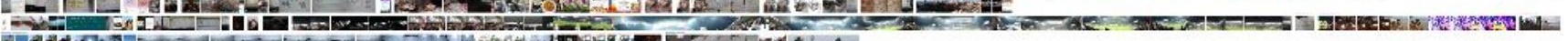

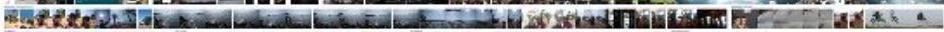

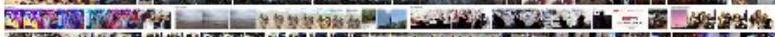

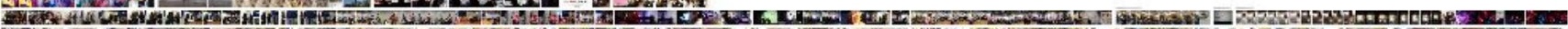

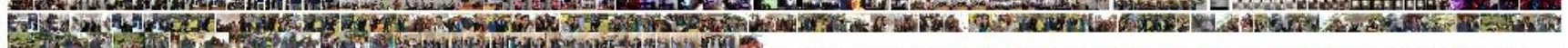

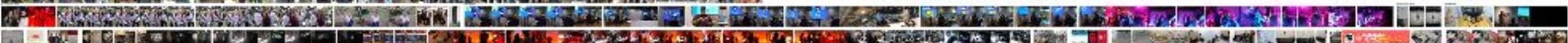

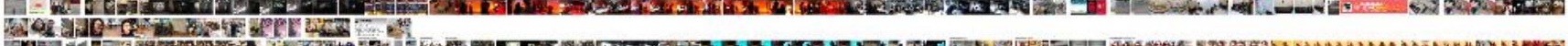

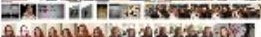

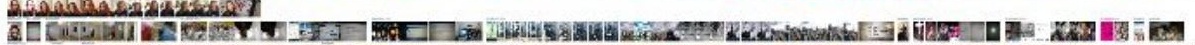



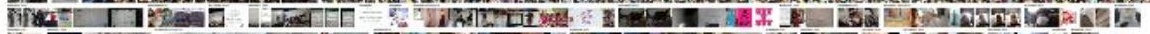

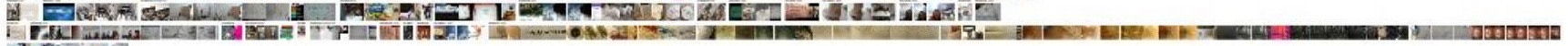

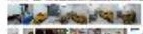

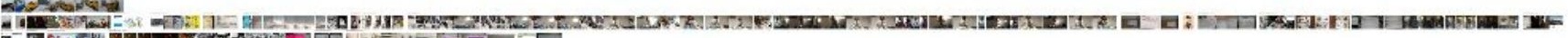

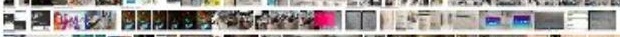

2.

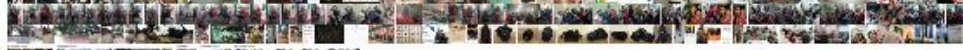

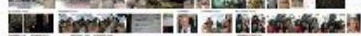

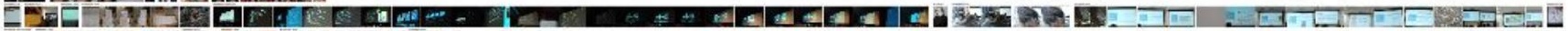
戛

1

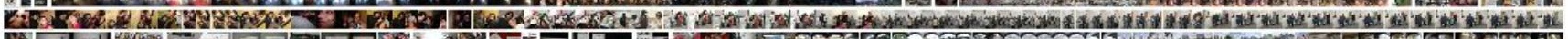

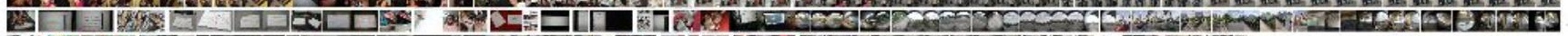
24a

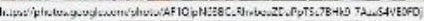

Fig. 5: Registro de banco de dados imagético pessoal de Fernanda Oliveira, criado automaticamente pela plataforma Google Fotos, 2019. Fonte: Acervo pessoal.

Como sintoma desse novo regime de comunicação em rede, que impõe um tempo de produção desenfreada de imagens, tornou-se hábito a criação de arquivos de dados digitais pessoais que compartiIhados em redes sociais, nuvens e sites implicam na criação de banco de dados imagéticos gigantes. E são esses dados que ditam o poder hoje. O domínio sobre um acervo de informações, os chamados big-datas, é impulsionado pelo crescimento da presença de dispositivos tecnológicos em nosso cotidiano, como exemplifica o fotógrafo e pensador da fotografia contemporânea Leandro Pimentel, no seu livro $\bigcirc$ inventário como tática: a fotografia e a poética das coleções:

A partir do final do século XX, o crescimento dos arquivos de dados digitais, assim como o aprimoramento das ferramentas de busca e distribuição, abriram uma diversidade 
de usos funcionais e poéticos estimulados pelas novas relações fomentadas pelas novas tecnologias. Na medida em que essas formas de organização e disponibilização de dados se multiplicam e se popularizam por meio das redes digitais e dos instrumentos de conexão portáteis. [PIMENTEL, 2010, p.21]

Para compreender a lógica de arquivos digitais, partimos da reflexão sobre tensões impostas pelas tecnologias digitais à forma de produção e circulação das imagens e seus impactos nos sujeitos espectadores, esse mesmo sujeito que é objeto de estudo de Marie-José Mondzain em seu livro homo spectator: ver > fazer ver. Sobre ele, pergunta-se a autora:

Quem é este homem espectador que está em vias de se transformar numa partícula elementar de uma massa designada 'público', num certo ambiente tecnológico, industrial e financeiro? [...] É por o espectador ser causa de si, causa do que vê e do que dá a ver, que esta breve meditação retomará necessariamente a questão do autor e a do actor. [MONDZAIN, 2015, p.22]

Levando aos extremos os modos como as imagens circulam e agem na contemporaneidade, percebemos que o poder das imagens digitais está na forma como a rede desloca o espectador do lugar da passividade imposta pela mídias tradicionais, em que o sujeito inerte é atingido pelos estímulos visuais, estando na posição de observador, para o lugar do espectador ativo, em que o sujeito, para ter acesso a algum tipo de visualização, precisa interagir diretamente com dispositivos de mediação, no caso a imagem.

O grande problema dessa nova forma de agenciamento dos arquivos é que as principais redes fazem parte de grandes corporações e ficamos espectadores das destinações que o capital pretende dar para essas informações, bem como para suas visibilidades.

Leandro Pimentel chama de inventariar o ato de "escolher, recolher, nomear, numerar, classificar e deixar à disposição" [PIMENTEL, 2010, p.27], e é a partir de tal definição que deve ser entendido o poder da visibilidade dos arquivos de fotografias e suas possibilidades de agenciamentos.

$\bigcirc$ arquivo transcende o instante de sua composição e passa a envolver gestos que recaem sobre conjuntos de imagens. Sendo assim, a questão não é mais interrogar aquilo que move o gesto singular de produzir imagens, mas sim a intenção que leva a escolher, nomear, seriar, apresentar e compartilhá-las.

\section{CONSIDERAÇÕES FINAIS}

O fato de que imagens estão em trânsito é próprio de uma forma de olhar complexa sobre o fenômeno imagético. E estão em trânsito não apenas porque 
circulam socialmente e em determinado tempo, mas porque transitam entretempos e entre-espaços, ocupando diferentes estatutos, agenciando diferentes questões e poderes, sem deixar de trazer consigo o lastro de muitas histórias. Imagens são "sujas". Carregam impurezas de todas as conexões que já fizeram no tempo e no espaço. Têm sua história, que cumpre escavar/conhecer.

Fundamentalmente, elas provêm de um gesto humano; gesto que inaugura um espaço de disputa, pois, se uma imagem é um espaço crítico narrativo de desejo, ela consequentemente pode ser deslocada para um espaço de poder. Se a imagem como objeto é constituída na relação com o espectador, o poder está na mão de quem a destina e na forma como se dá essa destinação.

Sendo essa forma a dos arquivos, que tampouco são inertes, multiplicam-se as estratégias de poder: entre os movimentos de escolher, recolher e nomear, escondem-se apagamentos e silenciamentos programados, que apenas uma visada crítica e não ingênua é capaz de fazer emergir.

\section{NOTAS}

1 As pesquisas que deram origem a este artigo têm apoio da CAPES [Coordenação de Aperfeiçoamento de Pessoal de Nível Superior] e da FUNCAMP [Fundação de Desenvolvimento da Unicamp] FAEPEX 2029/19.

2 Nesse ponto é importante ressaltar que não nos referimos apenas ao sentido concreto da palavra trânsito, que casa com a ideia de circulação. Pensamos que uma imagem está em trânsito, mesmo quando não circula. $\bigcirc$ trânsito é aqui concebido como virtualidade, potência do devir imagem. Se foi lançada no mundo, está em trânsito, à espera de alcançar suas destinações. 3 Princípio arcôntico é formador dos arquivos. Segundo Derrida:" [...] o sentido de 'arquivo' [...] vem para ele do arkheîon grego: inicialmente uma casa, um domicílio, um endereço, a residência dos magistrados superiores, os arcontes, aqueles que comandavam. Aos cidadãos que detinham e assim denotavam o poder políitico reconhecia-se o direito de fazer ou de representar a lei. [DERRIDA, 2001, p. 12]

4 Ressaltamos o fato de o arquivo de fotografias ser predominantemente" fotográfico, por considerar que nele existem outras materialidades, como, por exemplo, impressos, álbuns e envelopes. Essas materialidades, embora marginais, são fundamentais para a fruição das fotografias.

5 Termo que remete à fotografia analógica e se refere ao momento em que a imagem já existia na película, mas permanecia invisível à espera da revelação. 
ABREU, Leandro Pimentel. O inventário como tática: a fotografia e a poética das coleções. Rio de Janeiro: Contra Capa, 2014.

ALLOA, Emannuel [org.]. Pensar a imagem. Belo Horizonte: Autêntica, 2017.

BEIGUELMAN, Giselle. Imagens da mesmice: do banal ao radical. Disponível em https://revistazum.com.br/ colunistas/banal-ao-radical/. Acesso em 09 set. 2019

COLOMBO, Fausto. Os arquivos imperfeitos. São Paulo: Perspectiva, 1991.

DERRIDA, Jacques. Mal de arquivo: uma impressão freudiana. Rio de Janeiro: Relume Dumará, 2001.

FERNANDES JÚNIOR, Rubens. O silêncio e a passividade de um novo começo. 2012. Disponível em http:// www.iconica.com.br/site/o-silencio-e-a-passividade-de-um-novo-comeco. Acesso em 22 out. 2017.

FONTCUBERTA, Joan. A câmera de Pandora: a fotografi@ depois da fotografia. São Paulo: Editora G. Gili, 2012.

LE GOFF, Jacques. História e memória. Campinas: Unicamp, 2013. 
MARTINS, José de Souza. Sociologia da fotografia e da imagem. São Paulo: Contexto, 2008, p. 47.

MONDZAIN, Marie-José. A imagem entre proveniência e destinação. In: ALLOA, Emmanuel [org.]. Pensar a imagem. Belo Horizonte: Autêntica, 2017, pp. 39-53.

MONDZAIN, Marie-José . A Imagem Pode Matar? Lisboa: Nova Vega, 2009.

MONDZAIN, Marie-José . homo spectator: ver > fazer ver. Lisboa: Orfeu Negro, 2015.

MONDZAIN, Marie-José. Imagem, Sujeito, Poder. [Entrevista original concedida a Michaela Fiserova]. Tradução: Vinícius Nicastro Honesko. In: O monstro à mostra: mostruário, Florianópolis: outra travessia, n.22, 2016, p.175 - 192. Disponivel em https://periodicos.ufsc.br/index.php/Outra/article/view/21768552.2016n22p175.

SANTIAGO JÚNIOR, Francisco. Dimensões historiográficas da virada pictórica/icônica ou o que pode fazer o historiador quando faz histórias com imagens? Tempo e Argumento, v. 11, p. 402-444, 2019. 


\title{
CASA-EXÍLIO', PALAVRA-MAPA
}

Home-exile, map-word

Casa-exilio, palabra-mapa

> Karina Dias [Universidade de Brasília, Brasil]*

Luciana Ferreira [Universidade de Brasília, Brasil) * *

\begin{abstract}
RESUMO O que é o exílio? - esta é a questão que norteia o diálogo entre dois pensamentos. No primeiro, o exílio é entendido como a perda de uma casa, um lançamento no mundo, onde a procura da casa acontece de forma incessante e sem garantias. No segundo, o exílio é vivido como a perda do mundo pela condição de se ter que permanecer dentro da própria casa, portanto, quando o mundo precisa ser percorrido e inventado entre as suas paredes. $O$ texto explora as nuances desses dois pensamentos em diálogo com trabalhos de artistas visuais e, em alguns momentos, na sua relação com a palavra, ora uma palavra exilada, ora uma palavra-mapa.

PALAVRAS-CHAVE Casa; exílio; palavra; arte contemporânea.
\end{abstract}

* Karina Dias é Pesquisadora e Professora associada do Departamento de Artes Visuais da Universidade de Brasília. E-mail: karinadias. net@gmail.com

* * Luciana Ferreira é Pesquisadora no Programa de Pós-graduação em Artes Visuais (PPGAV) da Universidade de Brasília. E-mail: lusmferreira@yahoo.com.br 
DIAS, Karina; FERREIRA, Luciana. Casa-exílio, palavra-mapa. Revista Poiésis, Niterói, v. 23 , n. 39, p. 205 223, jan./jun. 2022 [DOl: https://doi. org/10.22409/poiesis.v23i39.48997]

Este documento é distribuído nos termos da licença Creative Commons AtribuiçãoNão Comercial 4.0 Internacional (CCBY-NC) (c) 20221 Karina Dias, Luciana Ferreira. Submetido: 5/3/2021; Aceito: $25 / 5 / 2021$
ABSTRACT What is the exile? - that is the question that guides the dialogue between two thoughts. In the first one, the exile is understood as the loss of a home, a launch to the world, where the search for a home happens in an incessant and free of guarantee way. In the second one, the exile is experienced as the loss of the world for the condition of having to remain inside its own house, therefore, when the world needs to be crossed and invented between its walls. The text explores the nuances of these two thoughts in dialogue with the works of visual artists and, at some points, in its relationship with the word, sometimes an exiled word, sometimes a map-word.

KEYWORDS Home; exile; word; contemporary art.

RESUMEN ¿QQué es el exilio? - esta es la cuestión que guía el diálogo entre dos pensamientos. En el primer, el exilio es entendido como la pérdida de una casa, un lanzamiento al mundo, en donde la búsqueda de la casa ocurre de forma incesante y sin garantías. En el segundo, el exilio es vivido como la pérdida del mundo por la condición de tener que permanecer dentro de la propia casa, por lo tanto, cuando el mundo necesita ser recorrido e inventado entre sus paredes. El texto explora los matices de esos dos pensamientos en diálogo con trabajos de artistas visuales y, en algunos momentos, en su relación con la palabra, por veces una palabra exiliada, por veces una palabra-mapa.

PALABRAS CLAVE Casa; exílio; palabra; arte contemporâneo. 
Ana Maria Martins, em Como se fosse a casa[2017], escreve:

a vontade de partir antecede sempre

a casa

estamos para ir

prestes, mas não prontos

só vigor e vontade

lar, ela pensa, é sempre lá

Talvez assim comece o exílio. Sem dúvida, é a procura de uma casa. Acontece quando a casa que temos, por desejo ou por necessidade, não pode mais permanecer. É preciso partir.

Em outra passagem do mesmo texto [2017], Ana Maria Martins continua: espaço interior, elegeu a casa como elemento privilegiado. Seria ela o "nosso canto do mundo", o nosso "primeiro universo", um lugar de acolhimento dos nossos sonhos e devaneios. Sonhos e devaneios exigiriam a segurança de paredes sólidas e de um teto que protegeria das tempestades, um "não-eu que protege o eu" [BACHELARD, 2008, p.24]:

[...] todo espaço realmente habitado traz a essência da noção de casa.

[...] Na vida do homem, a casa afasta contingências, multiplica seus conselhos de continuidade. Sem ela, o homem seria um ser disperso. [BACHELARD, 2008, p.24-26]

A casa teria, assim, um valor intrinsecamente maternal, de profundo amparo, proteção e acolhimento da existência humana. E haveria, como referência mais profunda, a "casa natal", a casa das memórias mais antigas, onde os hábitos se firmaram:

penso que só sabe da casa quem precisa atravessar rapidamente uma fronteira quem fez sua casa num país que não o quer aqueles a quem a casa segue como um cão

Bachelard, pretendendo fazer uma fenomenologia do espaço e, com ela, dos valores de intimidade do
A casa natal é a casa habitada [...] para além das lembranças, a casa natal está fisicamente inserida em nós. Ela é um grupo de hábitos orgânicos. [...] gravou em nós a hierarquia das diversas funções de habitar. Somos o diagrama das funções de habitar aquela casa; e todas as outras não passam de variações de um tema fundamental. [BACHELARD, 2008, p.33-34] 
existência com o lugar. Estabelece padrões que sugerem a estabilidade e permitem que a casa habitada cumpra a sua função de proteção. O hábito adquirido no habitar a casa natal é transferido para e reproduzido nas outras casas, perpetuando a sensação de segurança.

Mas acontece de perder a casa. Acontece o exílio. Como segue esse que perdeu o seu canto do mundo? Para onde vai esse ser agora disperso?
Estas questões nos tomam com sua máxima intensidade quando nos deparamos com as imagens de Centro di permanenza temporânea. Um vídeo registra pessoas - claramente imigrantes - em uma escada de aeronave, em uma pista de um aeroporto, sem qualquer avião próximo. Não sabemos de qual aeroporto se trata, não sabemos a que país pertence, não sabemos quem são essas pessoas, não sabemos de onde vieram, não sabemos para

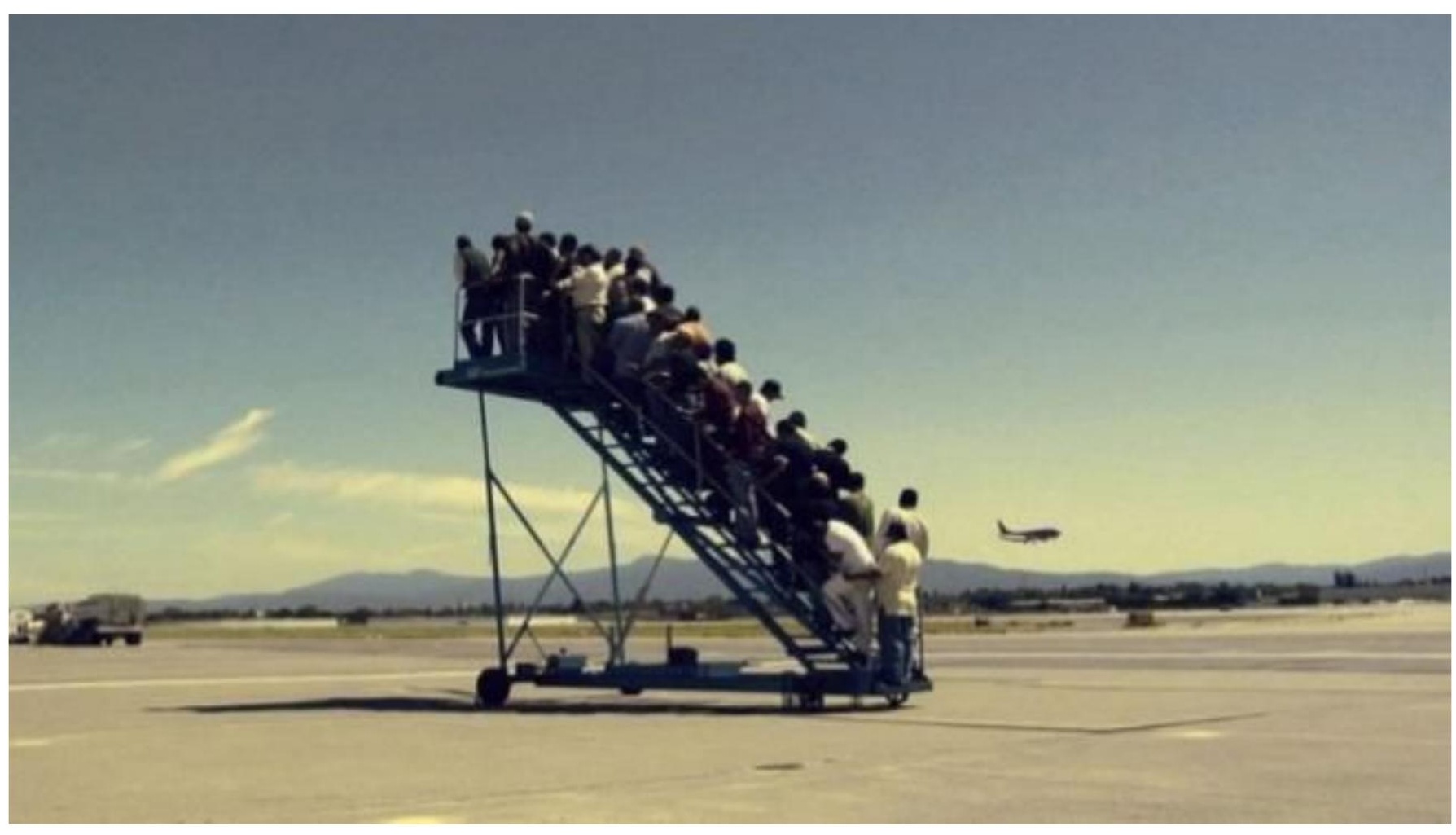

Fig. 1 - Adrian Paci, Centro di permanenza temporanea, 2007

Fonte: https://welldesignedandbuilt.com/2012/03/02/adrian-paci-centro-di-permanenza-temporanea/[acesso em 18.02.21]

DIAS, Karina; FERREIRA, Luciana. Casa-exílio, palavra-mapa. 
onde vão. Não possuem sequer bagagem. Apenas esperam em um espaço suspenso que é também um hiato temporal entre o que foi e o que será. A imagem, que por vezes enquadra alguns rostos, não nos informa nada. Dá-nos apenas o duro contato com a espera calma, desinformada, lacunar de pessoas que não conseguem pisar o chão, deslocadas no próprio lugar. ${ }^{2}$

O expatriado é para Blanchot não apenas aquele que perdeu seu país, mas o que descobriu um modo de habitar sem hábito [BLANCHOT, 2010b, p.42]. O exílio que enfrenta exige o abandono do hábito. Por isso a casa é difícil, embora permaneça sempre uma procura incessante. Uma procura, por força, desapegada da casa natal. Uma procura, porquanto urgente, não exigente. O exílio é um trânsito, uma chegada que não se conclui, uma partida que nunca termina. Um estado suspenso. Todo exilado é um estrangeiro diante do mundo e diante de si mesmo.

Mas, quem é o estrangeiro? - pergunta Maldonado. E ensaia uma resposta:

[Aquele que] Vem de longe. [...] [que] tem que deixar a terra dos pais, a casa, a memória. [...] Migra, o estrangeiro. E ao migrar desmancha qualquer vínculo com a saudade e a tradição [...] Seus adeuses não deixam rastro ou memória. Nenhuma memória tem respostas. Pois nenhuma resposta pode se dar senão o olvido: o olvido que se torna ausência; a ausência que para dizer de si não necessita raízes; raízes que o êxodo da língua materna e da ilusão de que uma palavra possa des-velar [e não apenas revelar] transforma em pura errância. [MALDONADO, 2004, p. 30-31]
O estrangeiro é o que se despede. Deixa para trás a estabilidade da casa e dos sonhos. Deixa para trás a língua materna, a casa de todas as casas. Salta em um abismo de profundidade não mensurável, onde não se faz abrigo. O estrangeiro é uma pergunta. E, sendo essa pergunta inquieta e insistente, ela mesma imprecisa, já não espera por qualquer resposta.

Um estrangeiro nunca se sente em casa. Ele atravessa a soleira de uma casa que não lhe pertence e espera, nela, encontrar hospitalidade. "A hospitalidade pressupõe [...]a possibilidade de uma delimitação rigorosa das soleiras ou fronteiras: entre o familiar e o não-familiar, entre o estrangeiro e o não-estrangeiro" [DERRIDA, 2003, p.43]. E, uma vez atravessada a soleira, aquele diante do estrangeiro, primeiramente, pergunta-Ihe o nome. Não se oferece hospitalidade sem que o estrangeiro se defina como estrangeiro. É preciso saber quem ele é e de onde vem para submetê-lo às leis da hospitalidade, pois, "do ponto de vista do direito, o hóspede, mesmo quando bem recebido, é antes de tudo um estrangeiro, ele deve continuar estrangeiro." [DERRIDA, 2003, p.63]. E tudo isso já está posto no momento primeiro quando, atravessada a soleira, o estrangeiro precisa se apresentar em uma língua que não Ihe pertence. 
Mas Derrida se pergunta se não seria possível outra hospitalidade:

A hospitalidade consiste em interrogar quem chega? Ela começa com a questão endereçada a quem vem [...]: como te chamas? [...] Ou será que a hospitalidade começa pela acolhida inquestionável, num duplo apagamento, o apagamento da questão e do nome? É mais justo e mais amável perguntar ou não perguntar? [...] Oferece-se hospitalidade a um sujeito? A um sujeito identificável? A um sujeito identificável pelo nome? Um sujeito de direito? Ou a hospitalidade se torna, se dá ao outro antes que ele se identifique, antes mesmo que ele seja [posto ou suposto como tal] sujeito, sujeito de direito e sujeito nominável por seu nome de família, etc? [DERRIDA, 2003, p.26-27] venda a sua imagem de "homem exótico". A placa é escrita em inglês, língua oficial do país onde se encontra, diante do qual, enquanto homem exótico, afirma-se como o estrangeiro deslocado, não pertencente. Ao colocar a sua imagem à venda, negocia a sua permanência. A cena acontece, entre outros momentos, diante de uma kombi repleta de bananas, dentro da sua exposição na Art Basel, em Miami. Aqui, o estrangeiro parece submeter-se, com ironia, às leis da hospitalidade impostas pelo direito local.

Há, na hospitalidade, uma antinomia entre as leis da hospitalidade previstas pelo direito e a lei incondicional da hospitalidade. São dois regimes contraditórios e inseparáveis, onde a lei incondicional necessita das leis do direito enquanto as corrompe e subverte, pois a lei incondicional da hospitalidade seria sem lei, desprovida de deveres e imperativos [DERRIDA, 2003, p.69-73].

Esgarçar ao limite a questão do estrangeiro e da hospitalidade foi o que fez Paulo Nazareth. Em 2011, percorreu a pé e de carona o caminho da sua casa em Minas Gerais até a América do Norte. No percurso, fez uma série de registros da experiência que estão reunidos no trabalho Notícias da América. Em um desses registros, o artista carrega no peito uma placa de papelão escrita à mão onde coloca à
Em outro momento desse percurso, Paulo Nazareth está em frente a uma placa do estado do Arizona onde, dessa vez, carrega no peito outra placa de papelão escrita à mão, agora em espanhol, dizendo que também temos direito àquela paisagem. Então, Nazareth afirma a América Latina reivindicando o pertencimento ao lugar. Neste momento, há uma tentativa de explosão de fronteiras:

Mi concepto de patria todos los dias se expande... nascido en Brasil soy latino americano, siendo latino americano soy tambien mexicano... soy parte de cada tierra por donde pisaron mis pies... no hay como separar estas tierras con una linea imaginaria llamada frontera... quiza sea por eso que llevantaron el muro al norte: un intento de impedir que Mexico siga siendo Mexico adentro de Estados Unidos. [NAZARETH, 2009, s/p] 


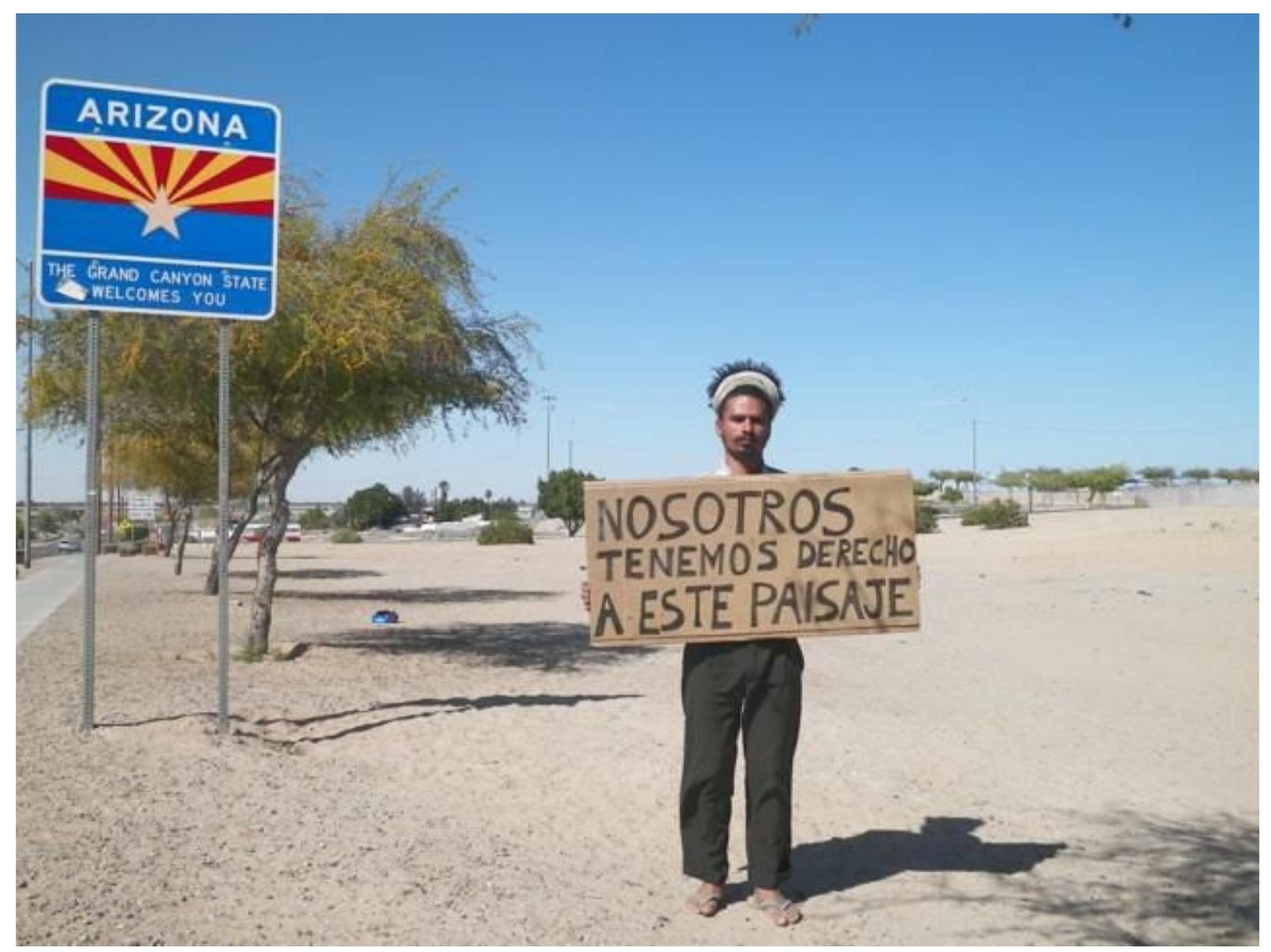

Fig.3 - Paulo Nazareth, série Notícias da América, 2011 -2012

Fonte: https://artebrasileirautfpr.wordpress.com/2013/02/26/paulo-nazareth/[acesso em 18.02.21] 
Outro estrangeiro, Edmond Jabès, de uma família de origem judia francófona, nascido no Cairo, com nacionalidade italiana [sem jamais ter vivido na Itália], exilou-se na França. Em certo momento, afirmou nunca saber onde se encontrava, pois se sentia na França quando habitava o Egito e, uma vez na França, sentia-se sempre em outro lugar. "O estrangeiro já não sabe qual é o lugar" [Jabès, in MALDONADO, 2004, p.29]. E assim seguiu, ainda que desejando firmar morada, sem apego a ela, fazendo da sua existência uma contínua viagem onde tudo é transitório.

Disse Jabés:

$[\ldots]$

Deixei uma terra que não era minha,

troquei-a por outra que, tampouco, me pertence.

Refugiei-me num vocábulo de tinta, que tem o livro como espaço;

palavra de lugar nenhum, palavra obscura do deserto.

Não me cobri, à noite.

Não me protegi do sol.

Andei nu.

De onde eu vinha, já não tinha sentido.

Para onde ia, não havia quem se importasse.

Vento, digo-lhes, vento.

E um pouco de areia no vento.

[JABÈS in MALDONADO, 2004, p.29]
E segue Jabès compartilhando o sentido do deserto imagem escolhida por ele para traduzir a sua errância exilada - a partir da experiência de quem o viveu na carne como ferida exposta. O deserto é, para ele, ausência de paisagem, o lugar de um não-lugar, ausência de qualquer referência e, portanto, ao mesmo tempo, distância e não distância, e ainda a própria separação que é abertura do lugar [JABÈS, 1991, p.61]. Assim como é o deserto, é também o exílio.

Ora, se há deserto [se há exílio], se não há casa, há de se buscá-la. Ainda que sem hábito, habitar. De alguma maneira, encontrar uma forma de estar em um lugar. Uma forma de "organizar, entretanto, esta terra como residência." [BLANCHOT, 2010a, p.73] Jabès confessa ter encontrado abrigo no livro, onde o exílio, de alguma maneira, pôde ser casa.

Curioso que, no máximo da indigência e do não pertencimento, tenha havido esse encontro de um abrigo em um livro, ainda que com "palavras de lugar nenhum". Um refúgio "num vocábulo de tinta, que tem o livro como espaço". Fazer não de um país, mas da língua a casa-exílio. Habitar o estrangeiro na palavra. Pela língua, morar no exterior [não somente de um lugar, mas da experiência]. E, assim, fazer da casa uma intimidade ao avesso, que lança para fora e acolhe no fora. O externo como experiência de morada. A errância como norte e caminho conhecido. A intimidade do fora. 


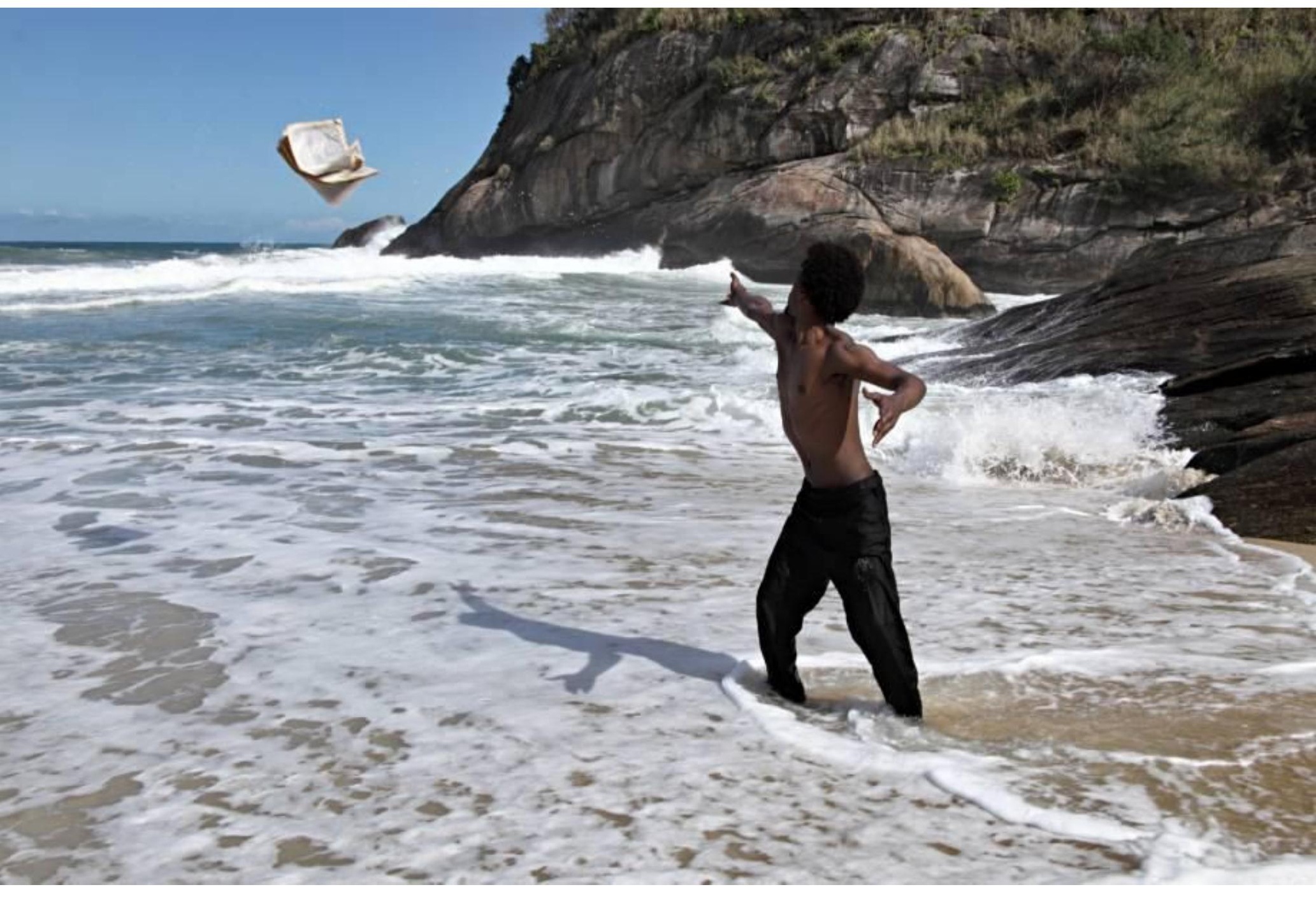

Fig.4: Regina de Paula, Para o levante, 2015-2016

Fonte: : hitps://ogimg.infoglobo.com.br/in/18936623-464-ee0/FT 1086A/652/2016-896524535-para-o-levante_video-regina-de-paula_fotowilton-montenegr.jpg [acesso em 18.02.21]

DIAS, Karina; FERREIRA, Luciana. Casa-exílio, palavra-mapa. 
Blanchot [2010a] fala da "paixão pelo Exterior"3. Para ele, esse é o caminho para se pensar uma língua impossível, ou seja, uma língua que não pode, uma língua sem poder, distante da compreensão apropriadora. Somente uma separação assim infinita, que remete ao absolutamente outro de mim, pode afirmar uma palavra plural, não submetida à violência da única palavra.

A língua que interessa a Blanchot é a língua exilada, a língua que não estabelece morada senão no próprio exílio. A língua interrompida tantas vezes, tão deslocada de si, tão em trânsito, tão estrangeira, que não possa ser tomada como última palavra. Que acolha, portanto, a indigência, a diferença, a dúvida. Uma língua, enfim, sem qualquer verdade, um livro lançando ao mar, como em Para o levante, de Regina de Paula.

Mas, e quando o exterior não é só um lugar infinitamente distante para onde a palavra aponta, mas um lugar dentro da própria palavra? Ou seja, quando, na palavra, o fora se abre por dentro? Nessa língua mal-dita ${ }^{4}$, acontece de o exterior ser íntimo, de o fora ser um tipo de infiltração que toma a palavra na sua intimidade secreta e abala a sua estrutura interna. $\bigcirc$ exterior mergulha na palavra e a divide infinitamente a partir do seu interior. $\bigcirc$ exte- rior, agora, está dentro da palavra, a palavra passa a ser o seu fora. A palavra é exilada de si.

Quando isso acontece, quando a separação infinita está dentro da palavra, a descontinuidade penetra no interstício, no espaço vacante, e segue espaçando ainda mais para que o fora nasça dentro da palavra e the pertença como elemento constituinte fundamental. Enquanto há a intimidade do fora, compreendemos que o fora é também o que há de mais íntimo. 0 infinitamente distante é também o mais próximo.

Essa é a experiência sugerida por Quase notas para quase pensamentos. Nela, um poema de Gertrude Stein e a sua tradução por Augusto de Campos são rasurados com fita corretiva branca, de modo que apenas a última letra antes de cada pontuação e a pontuação correspondente permanecem intactas. Surge, dessa experiência, uma leitura completamente nova. Há, neste trabalho, um convite para uma oralidade primeira, um balbucio de letras soltas, constituído de puro gozo sonoro. Deparamo-nos com uma espécie de coleção de sopros que formam um pequeno texto de quase anotações aéreas às quais correspondem, talvez, pensamentos insipientes, não desenvolvidos, expressos por desenhos visuais desses fragmentos de sons agora estrangeiros no próprio poema de origem. O novo texto deslocado busca abrigo na antiga página-casa que agora se tornou exílio. Pode, a própria casa, ser exílio? 


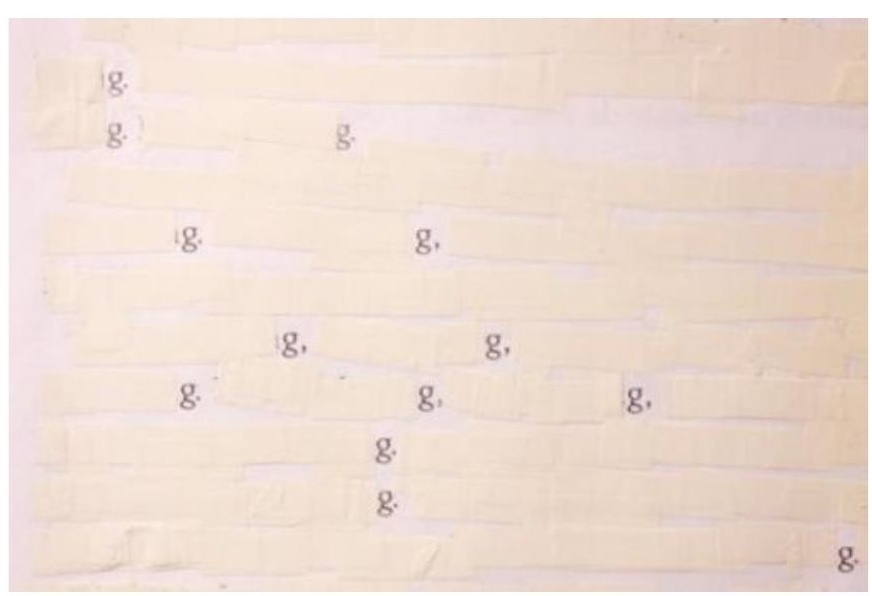

Fig.5 - Luciana Ferreira, Quase notas para quase pensamentos [original e tradução], [detalhes], 2016 Fonte: acervo da artista

\section{CASA-MUNDO OU QUANDO A TERRA NOS EXILA}

Todos os dias vou a minha biblioteca e encontro a coragem, todos os dias abro aleatoriamente um livro, todos os dias leio as mesmas palavras: "onde poderia cair sem desastre?"5

Estar em casa todos os dias até que nos sintamos exilados do mundo. Exilados do mundo, abandonados pela terra 6 . Como nomear aquele que perdeu o mundo? O que permanece como questão? Se um estrangeiro nunca se sente em casa, porque perdeu o teto protetor, em que medida aquele que o.

a.

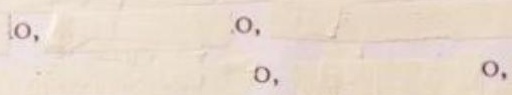

a.

a.

a.

ia.

não pode mais sair de casa se torna também estrangeiro ao teto que o protege? A quem esperamos dar hospitalidade quando aquele que chega somos nós mesmos? Já não sabemos qual o nosso lugar. Permanece, como nos lembra Anne Dufourmantelle [2003, p.50] o onde, como sendo a questão do homem. A autora continua salientando que Derrida nos faz compreender que ao próximo não se opõe o algures, mas uma outra figura do próximo. E esta geografia nos conduz ao onde? Nos conduz a interrogar-nos sobre a relação essencial com o lugar, com a morada e com o sem-lugar. Na impossibilidade de estarmos no mundo atravessamos a soleira de nossas casas para aí permanecermos indefinidamente. $\bigcirc$ que era antes um território está- 
vel, agora se transforma em um espaço em que as fronteiras entre o interior e o exterior se encontram esfumaçadas. Se a hospitalidade é uma relação ambivalente com o espaço e se revela como um gesto de acolhida, de dar lugar a quem chega [DUFOURMANTELLE, 2003, p.58], sejamos nós aqueles que, a um só tempo, acolhem incondicionalmente a própria casa e são acolhidos por ela. Casa [in] cômoda, que nos confirma que não ocupamos mais o centro da cena, que perdermos o ponto de vista privilegiado sobre as coisas e nos sentimos à beira do abismo. Deslocados não reinamos mais despotamente. Fomos lançados à margem para, dali quem sabe, reinventar uma existência.

Nesse movimento, a casa-forte que nos protege da eminente ameaça é também o farol ${ }^{7}$ por onde observamos os movimentos da terra. Se habitar é uma geografia [DELEUZE, PARNET, 1996, 159] é preciso reencontrar o seu relevo. Nesse estado-de-cabana permanecemos [i]móveis?

Levinas nos lembra que ao nos deitarmos, ao nos encolhermos em um canto para dormir, nos abandonamos ao lugar, ele se torna nosso refúgio como base [LEVINAS, 1993, p.119]. O geógrafo Eric Dardel [DARDEL, 2011, p.41] completa que é desse lugar, base de nossa existência que despertando, tomamos consciência do mundo e saímos ao seu encon- tro. Na impossibilidade de sairmos audaciosamente rumo aos espaços para além da casa, nos resta compreender que a casa é um vasto mundo. Não há como não lembrar de Mercator[1609], cartógrafo flamengo do século XVI, que descrevia a casa como um pequeno mundo e o mundo como uma grande casa. Mas a pergunta que nos assombra atualmente e que se mantém como um sussurro incessante é o que acontece quando perdemos o mundo? Vale reler o poema de Albert Camus [1939-53] Do mar bem perto onde o poeta escreve:
... quando perdi o mar, todos os luxos passaram a ter para mim aparência opaca .... Desde então espero. Espero as naves de retorno, a morada das águas, o dia límpido. Aguardo pacientemente com todas as minhas forças muito bem brunidas. [CAMUS, 1939-53]
Perder o mar, perder a paisagem, como se todas as paisagens tivessem, momentaneamente, recuado e nesse recuo, resta-nos ocupar uma exígua faixa de terra [MALDONADO, 2004], um solo primeiro que nos convida a experimentar de forma radical a nossa casa. Confinados em nossas moradas, experimentamos distâncias que nos conduzam ao que nos resta da concretude do mundo [a sua materialidade] e a uma topologia mental, uma finisterra do espírito como afirma Kenneth White [WHITE,1987]. Nessa dinâmica toda imagem fabrica distâncias, cria tempos distintos, é ponto de vista e ponto de 
contato, detalhe e panorama. Nesse desejo de espaço, espaçamo-nos... somos um corpo movendo-se no espaço [WHITE,1994] criamos paisagem, inventamos lugares, deambulamos, talvez, em busca de um alhures possível... lá, onde estivermos.

Emergiriam daí outras rotas, um espaço de navegação a bordo de todos os dias ${ }^{8}$ ? Vagamos, quem sabe, em busca dos ventos, dos mares e das correntezas, franqueamos distâncias, entrevemos continentes. Companheiros de um lugar que só conhecíamos, muitas vezes, de passagem, somos nesse exílio forçado viajantes das pequenas distancias. Habitar a proximidade como se um longínquo fosse, compreender que o espaço é sempre uma dúvida9 ${ }^{9}$ que a realidade geográfica é, como escreve Dardel [DARDEL, 2011], o lugar onde estamos. Nessa morada do íntimo, como [não] pensar em paisagem? Se a paisagem é a medida do olhar que silencia o ruído, ela também é onde a terra e o céu se tocam [CORAJOUD apud ROGER, 1995], um movimento mínimo e uma revolução máxima, sempre entre visão e invisão [DIAS, 2010] essa ressonância interna que nos confirma que a paisagem é mais que um simples ponto de vista óptico. Nessa justa aliança que une o lado objetivo daquilo que vemos com o lado subjetivo, íntimo a cada um de nós, a paisagem é um como-ver-se. Um ver de dentro que se desdobra no fora. Estar incluído e saber-se dis- tância. Nesse movimento nem sempre dócil, o olho que olha é também o que sonha.

Nesse exílio-morada-exílio, pode a paisagem morar na palavra? Pode a palavra armazenar o horizonte, condensar o mundo, sustentar a sua arquitetura? Habitar todas as línguas, escutar uma língua muda, praticar uma língua nômade, encontrar as palavras corajosas. [GALLIENNE, 2020], indagar os nomes. Reencontrar o caminho de volta à terra, sem esquecer que "bastaria um movimento de distração para afogar os cinco continentes. O mar não tem remorso..." [JABÈS apud MALDONADO, 2004, s/p] Pelas palavras chegar, pelas palavras refundar a morada

\section{A PALAVRA-MAPA:}

"Vocês, palavras, levantem, sigam-me e quando tivermos ido longe demais, iremos ainda mais longe, isso não tem fim", escreve a poeta Ingeborg Bachmann [BACHMANN, 2020, p.127]. O que resta quando a linguagem silencia? O vento, a respiração, a distância entre os corpos que se movem, as palavras miúdas ditas pelo caminho, inaudíveis porque, em movimento, são como os invisíveis detalhes que compõe um percurso. Como as flores que ficam na beira da estrada sem nome ou prestígio e que nos lembram que o próximo pode ser 
um vasto mundo. Reencontrar a língua do espaço. Formular efêmeros enunciados. Lem-

brar que mover exige coragem.

Das coisas às palavras, sempre em movimento, sempre movediças. "Como os nomes suportam portar os anônimos, indaga novamente a poeta?" [BACHMANN, 2020 p.25]. Os nomes são geografias, são como vozes que sussurram em uma língua desconhecida. São relevos, apontam direções,

distâncias, topografias nômades.

É preciso reencontrar o mapa. Rever percursos, reler palavras esquecidas, pousar e repousar nas distâncias percorridas, sem sair do lugar. Foi dessa experiência que surgiu o vídeo Sudamérica ${ }^{10}$. Nele o espectador acompanha o deslocamento em um mapa ao mesmo tempo em que uma voz em off narra sobre a viagem, o encontro com as fronteiras, a impossibilidade de se chegar e o que significa partir. No mapa, uma odisseia da palavra.

Se todo mapa é uma sombreada paisagem, é também uma nota, um esboço, uma mirada. Uma mirada forasteira. Uma vista intrusa ao nome. Possibili- dade de medida e efêmero contorno. Uma página para um atlas. O projeto para um globo. Quantos são os percursos, as horas vividas, os dias habitados, as luzes meridianas, o que não está posto?

A terra não cabe num mapa, tampouco as palavras não ditas e a história abandonada como um mato selvagem que encobre toda paisagem esquecida. O que dizem as vizinhanças silenciosas aos ruídos que vem do sul? De terra em terra, percorrer os lugares como se intrusos não fôssemos, nessa impossibilidade permanente, somos estrangeiros aos espaços e a seus nomes, mesmo os mais fraternais. Nessa casa que se tornou mundo, há muitos nomes para os ventos, há muitos 
nomes para os lugares. O movimento foi sempre o mesmo, atravessar de nome em nome uma faixa de terra, estar à margem, entrever um continente imaginado. Com o mapa, dar a volta ao mundo sem sair do lugar, cartografar distâncias oceânicas, fronteiras longínquas e estranhos nomes. As palavras são quilômetros.

Nesse mundo da proximidade que recua, do longínquo que [se] aproxima num instante [MARQUES,2009, p.64], noturnas são as distâncias. Habitar as fronteiras, seus modos, suas línguas, as palavras ferozes, os estranhos nomes. Quantas são as rotas de fuga? Possuir as direções. Guardar as distâncias. Abandonar o mapa, "lá onde a terra é aquilo que podemos perder num instante". [DARDEL, 2011, p.36]

\section{CONCLUSÃO}

O que acontece quando perdemos a casa? O que acontece quando perdemos o mundo? Nestas perguntas, que provocaram a nossa reflexão, duas experiências de exílio distintas se encontram: o exílio fora de casa e o exílio dentro de casa. Como se a casa fosse o lugar onde se quer estar quando é preciso partir, ou o lugar de onde se quer partir, quando é preciso estar. Em meio a tudo isso, surge a relação do exílio com a palavra, seja a que es- capa de um texto, seja a que aparece em um livro, um mapa, no relato de uma recordação de viagem. Palavra que fala sempre da urgência de pertencimento, seja a uma casa ou ao mundo.

Em comum a essas experiências aparentemente distintas, o fato de que todo exilado deseja estar em um lugar onde não se encontra. E, por isso, o exilado inventa para si o que precisa onde quer que esteja - seja a casa fora de casa ou o mundo fora do mundo. Toda casa se torna mapa de mundo medido em pequenas distâncias, todo mundo se torna canto de casa apoiado em distâncias infinitas. Percorrer esses caminhos é a aventura que revela que casa e mundo são sempre carregados conosco e que, portanto, nem a casa e nem o mundo podem, no fim, ser-nos retirados. 
1 Parte deste texto é composto por escritos extraídos, com alterações, dos capítulos Casa-exílio e Morada-murmúrio, originalmente escritos para a tese de doutorado, em artes visuais, intitulada Palavra-livro, casa-exílio [por uma língua mal-dita] de Luciana Ferreira, sob orientação de Karina Dias [Universidade de Brasília, 2017-2021]. O texto aqui apresentado foi enriquecido pelas reflexões sobre as obras citadas de Adrian Paci e de Paulo de Nazareth.

2 Adrian Paci, autor da obra, era ele mesmo imigrante, um albanês que foi para a Itália em 1992.

3 Sobre o tema, ver Conversa infinita - a palavra plural, p.8594.

4 A tese de uma língua mal-dita é apresentada em Palavra-livro, casa-exílio [por uma língua mal-dita] onde, entre outras coisas, pode-se ler: "Mal-dita é a língua maldita em sentido ordinário, amaldiçoada por não se adaptar às regras e às expectativas. Assim é, também e por isso mesmo, a língua que é dita mal, uma língua livre em buscar caminhos, que deve pouco às normas e às instituições que a regulam. Uma língua que implode os limites que garantem a boa comunicação."[2021, p. 54]. Programa de Pós-Graduação em Artes Visuais - PPGAV- Universidade de Brasília.

5 Iniciado no ano de 2020, em plena pandemia, Todos os dias é um trabalho em processo de Karina Dias. $\bigcirc$ trecho onde poderia cair sem desastre é de autoria do poeta Paul Valet.
6 Em referência à epidemia do Coronavírus que confinou populações inteira ao redor do mundo. A epidemia começou no inicio de 2020 e perdura pelo ano de 2021

7 Em sua dissertação de mestrado, em fase final, intitulada Terra caídas, como navegar em águas rasas - sob orientação de Karina Dias [UnB], a artista Raíssa Studart vem desenvolvendo a compreensão de sua casa como um farol.

8 Título do artigo inédito do Grupo de pesquisa Vaga-mundo: poéticas nômades [CNPq]. Coordenação Profa. Dra. Karina Dias.

9 Em referência à Perec que escreve : [...] l'espace est un doute il me faut sans cesse le marquer, le designer ; il n 'ést jamais à moi [...] in PEREC, Georges. Espèces d'espaces. Paris: Galillée, 2000, p. 179. O espaço é uma dúvida: eu preciso constantemente marca-lo, designá-lo; ele nunca é meu. [tradução das autoras].

10 Vídeo inédito de autoria de Karina Dias e Albert Amabelakiotis realizado ao longo de 2020. Realizado a partir do reencontro com um mapa da américa do sul utilizado durante uma viagem por esse continente- realizada de 1995 a 1996 - e dos diários de bordo do período que compreendeu o trajeto. 
BACHELARD, Gaston. A poética do espaço. São Paulo: Marins Fontes, 2008.

BACHMANN, Ingeborg. O tempo adiado e outros poemas. São Paulo: Todavia, 2020

BLANCHOT, Maurice. A conversa infinita - a palavra plural. São Paulo: Escuta, 2010a.

BLANCHOT, Maurice. A conversa infinita - a experiência limite. São Paulo: Escuta, 2007.

BLANCHOT, Maurice. A conversa infinita - ausência do livro. São Paulo: Escuta, 2010b.

CAMUS, Albert. Diários de viagem. O verão. 1939-1953. http://revistapandorabrasil.com/camus/caumus_ do_mar_bem_perto.htm Consultado em 27/2/2021.

CORAJOUD, Michel. Le paysage c'est l'endroit où le ciel et la terre se touchent in ROGER, Alain [org.] La théorie du paysage en France, 1974-1994. Seyssel: Champ Vallon, 1995.

DARDEL, Eric. O homem e a terra. São Paulo: Perspectiva, 2011.

DERRIDA. Jacques \& DUFOURMANTELLE, Anne. Da Hospitalidade. São Paulo: Escuta, $\mid 2003$.

DELEUZE, Gilles, PARNET, Claire. Dialogues. Paris: Flammarion, 1996. 
DIAS, Karina. Entre visão e invisão: paisagem [por uma experiência da paisagem no cotidiano]. Brasília: Editora do Programa de Pós-graduação em Arte, Universidade de Brasília, 2010.

GALIENNE, Alicia. L'autre moitié du songe m’appartient poèmes. Paris: Gallimard, 2020.

JABÈS, Edmond. A obscura palavra do deserto [uma antologia]. Lisboa: Cotovia, 1991

LEVINAS, Emmanuel. De l'existence à l'existant. Paris: Vrin, 1993.

MARQUES, Ana Martins \& JORGE, Eduardo. como se fosse a casa [uma correspondência]. Belo Horizonte: Relicário edições, 2017

MARQUES, Ana Martins. O livro das semelhanças. São Paulo: Companhia das Letras, 2009.

MALDONADO, Mauro. O estrangeiro. In: Raízes errantes. São Paulo: Ed.34, 2004.

MERCATOR. Atlas. Amsterdam, 1609.

NAZARETH.Paulo. Arte contemporânea/LTDA. Rio de Janeiro: Cobogó, 2012.

WHITE, Kenneth. Le plateau d'albatros, introduction à la géopoétique. Paris: Grasset, 1994.

WHITE, Kenneth. Le poète cosmographe. Bordeaux: Presses Universitaires de Bordeaux, 1987. 


\section{XAMANISMO EM FOTOLIVROS DE CLAUDIA ANDUJAR: YANOMAMI E AMAZÔNIA}

Shamanism in photobooks by Claudia Andujar: Yanomami and Amazônia

El chamanismo en fotolibros de Claudia Andujar: Yanomami y Amazônia

> Ana Carolina Albuquerque de Moraes [Universidade Estadual de Campinas, Brasil]*

RESUMO Este artigo propõe-se a analisar a abordagem do xamanismo yanomami pela fotógrafa Claudia Andujar em seus dois primeiros fotolivros, ambos de 1978: Yanomami: frente ao eterno (com Darcy Ribeiro) e Amazônia (com George Love). Em cada livro, são analisados o projeto gráfico, os assuntos dominantes e, sobretudo, o modo como o tema xamanismo é abordado. O viés das análises é sobretudo antropológico, coerentemente com o foco de Andujar na compreensão cultural dos Yanomami. Enquanto, em Yanomami, a abordagem do xamanismo é discreta, em Amazônia, é vigorosa pela quantidade de imagens dedicadas ao tema e a variedade de recursos visuais utilizados.

PALAVRAS-CHAVE Claudia Andujar; Xamanismo; Fotolivros; Yanomami; Amazônia.

* Ana Carolina Albuquerque de Moraes é professora do Departamento de Artes Visuais e Design da Universidade Federal de Sergipe e doutoranda em Artes Visuais na Universidade Estadual de Campinas. E-mail: carolina.moraes@gmail.com. Orcid: https://orcid. org/0000-0003-1560-2795 
DE MORAES, Ana Carolina Albuquerque. Xamanismo em fotolivros de Claudia Andujar: Yanomami e Amazônia. Revista Poiésis, Niterói, v. 23, n. 39, p. 224-252, jan./jun. 2022. [DOI: hitps://doi. org/10.22409/poiesis. v23i39.49154]

Este documento é distribuído nos termos da licença Creative Commons Atribuição -Não Comercial 4.0 Internacional (CC-BY-NC) (c) 2022 Ana Carolina Albuquerque de Moraes. Submetido: 12/3/2021 Aceito: 25/5/2021
ABSTRACT This article aims to analyze the approach on Yanomami shamanism by photographer Claudia Andujar in her first two photobooks, from 1978: Yanomami: frente ao eterno (with Darcy Ribeiro) and Amazônia (with George Love). The graphic design, the dominant subjects and, especially, the way in which the theme shamanism is addressed are analyzed in each book. The main bias employed in the analysis is anthropological, consistent with Andujar's focus on cultural understanding of the Yanomami. While in Yanomami the approach to shamanism is discreet, in Amazônia it is vigorous, due to the amount of images dedicated to the theme and the variety of visual resources employed.

KEYWORDS Claudia Andujar; Shamanism; Photobooks; Yanomami; Amazônia.

RESUMEN Este artículo se propone a analizar el enfoque del chamanismo yanomami por la fotógrafa Claudia Andujar en sus dos primeros fotolibros, ambos de 1978: Yanomami: frente ao eterno (con Darcy Ribeiro) y Amazônia (con George Love). En cada libro se analizará el proyecto gráfico, los asuntos dominantes y, sobre todo, la forma en que se aborda el tema del chamanismo. El sesgo de análisis es principalmente antropológico, consistente con el enfoque de Andujar en la comprensión cultural de los Yanomami. Mientras que, en Yanomami, el enfoque al chamanismo es discreto, en Amazonia es vigoroso, por la cantidad de imágenes dedicadas al tema y la variedad de recursos visuales utilizados. PALABRAS CLAVE Claudia Andujar; Chamanismo; Fotolibros; Yanomami; Amazônia. 
Claudia Andujar [1931-] aproximou-se do xamanismo e da cosmovisão yanomami aos poucos, à medida que construía uma relação de intimidade com as pessoas em suas sucessivas estadas na comunidade a partir dos anos 1970. Decidida a dedicar-se a um único povo por tempo indeterminado, foi-se inserindo entre os Yanomami e observando as relações interpessoais, as práticas cotidianas, a visão de mundo ali dominante. Desde o início, sentia a necessidade de entendê-los enquanto povo, mas, aos poucos, foi-se inteirando da complexidade da empreitada, pois compreender a visão de mundo de pessoas com origem e formação muito diferentes da sua, sem dominar a língua ali falada, não constituía tarefa fácil. A observação duradoura, participante, ao lado de outras estratégias que veio a conceber com o passar do tempo, como, por exemplo, a orientação para que algumas pessoas elaborassem desenhos representativos de sua própria realidade material e imaterial, foram recursos utilizados por Andujar para aproximar-se de um modo de vida tão marcado pela alteridade em relação a si mesma.

Alinhando-se a trabalhos anteriores [MORAES, 2018, 2019, 2020], este artigo propõe-se a analisar a abordagem do xamanismo yanomami pela artista em seus dois primeiros fotolivros: Yanomami: frente ao eterno, realizado em parceria com o antropólogo Darcy Ribeiro [ANDUJAR, 1978a], e Amazônia, este em parceria com o fotógrafo norte-americano George Love [ANDUJAR; LOVE, 1978]. As duas obras serão analisadas e comparadas quanto ao projeto gráfico, aos assuntos dominantes e, sobretudo, aos modos como o tema xamanismo é abordado em um e outro volume. Neste último ponto, as análises seguirão viés sobretudo antropológico, em consonância com o objetivo-mor de Andujar de compreensão cultural dos Yanomami.

A centralidade do tema xamanismo na obra da fotógrafa' pode ser vislumbrada em depoimentos seus, dentre os quais um que escreveu a respeito da série Sonhos Yanomami [1974-2003], cujas imagens constituem o foco da minha pesquisa de doutorado. ${ }^{2}$ Nessa série, concebida no início dos anos 2000, a artista sobrepõe fotografias de seu arquivo para refotografá-las sob novas projeções de luz, buscando evocar visões xamânicas. No depoimento em questão, afirmou a fotógrafa:

Considero a série 'Sonhos' um turning point em minha experiência com os Yanomami. As imagens que compõem a série revelam os rituais xamanísticos do Yanomami, 'sua reunião com os espíritos'. [...] Se o 
registro fotográfico de culturas pode ser considerado uma forma de compreensão do outro, eu acredito que com a série Sonhos eu consegui entender a essência do povo Yanomami [ANDUJAR, [2005].

Aquilo que Andujar considera "a essência do povo Yanomami" está, portanto, relacionado às visões acessadas pelos xamãs durante o transe - induzido pela inalação do psicoativo yãkoana ${ }^{3}$-, quando a cosmovisão yanomami revelar-se-ia do modo mais pungente, em virtude do contato dos xamãs com imagens ancestrais provenientes do passado absoluto. A série Sonhos é fruto da maturidade no relacionamento de Andujar com os Yanomami, após mais de trinta anos de convivência. Antes dela, a artista já havia abordado o tema xamanismo em outros trabalhos, como nas séries O invisível[1974-76] e Reahu[1974-76], e em sequências imagéticas em fotolivros, como Yanomami: frente ao eterno e Amazônia, focos deste artigo. Cada livro aborda o tema a seu modo, com maior ou menor ênfase, no âmbito de diferentes estratégias discursivas, conforme será aqui discutido.

Ambos os volumes foram publicados em 1978, pela Editora Praxis. Até então, Andujar havia estado entre os Yanomami em cinco momentos distintos: em 1971, enquanto fotografava para uma edição especial da revista Realidade sobre a região amazônica, estabelecendo seu primeiro contato com a comunidade; em dezembro do mesmo ano, durante três dias, na companhia de Love, então seu marido; em 1972, por cerca de um mês, acompanhando atividades cotidianas, como caça, pesca e coleta de mantimentos; em 1974, quando ali permaneceu a maior parte do ano, participando de modo imersivo das atividades coletivas e fotografando largamente as cerimônias funerárias denominadas reahu; entre 1976 e 1977, durante quatorze meses, quando desenvolveu projeto de pesquisa financiado pela FAPESP [Fundação de Amparo à Pesquisa do Estado de São Paulo], em que buscava estimular alguns Yanomami a desenharem e narrarem aspectos de sua própria cosmovisão, como forma de apreendê-la em maior profundidade [NOGUEIRA, 2018, p. 167-203].

Nas duas últimas estadas mencionadas, a fotógrafa estreitou os laços com o xamanismo yanomami. Em 1974, fotografando as cerimônias reahu, presenciou, por diversas vezes, a inalação coletiva de yãkoana pelos participantes do sexo masculino no último dia do evento. As festas reahu, que se estendem por vários dias e acolhem convidados de diferentes aldeias, são cerimônias funerárias em que os participantes lamentam os mortos e ingerem suas cinzas misturadas em mingaus, de modo a garantir a ascensão de seus espíritos 
para as "costas do céu" [KOPENAWA; ALBERT, 2015]. No derradeiro dia de festa, todos os homens inalam yãkoana e praticam xamanismo, buscando alcançar um outro patamar de consciência em que seria possível o contato com espíritos florestais. ${ }^{4}$

A relação de Andujar com aqueles identificados na aldeia como "xamãs" foi aprofundada enquanto a fotógrafa desenvolvia a pesquisa fomentada pela FAPESP, em 1976-77. Suas imersões anteriores em território yanomami despertaram-Ihe o interesse em conhecer mais detidamente aspectos da cosmovisão do grupo. A dificuldade de comunicarse oralmente com seus interlocutores foi um dos fatores que a impulsionaram a solicitar-Ihes a materialização em desenhos de aspectos dessa cosmovisão. Os conteúdos dos desenhos eram verbalizados por seus autores, e o material gravado em Yanomami era posteriormente traduzido para o português por Carlo Zacquini, missionário italiano que se tornou fiel parceiro da fotógrafa na luta pela causa ameríndia [ANDUJAR, 1978b]. Segundo Andujar, no interior do grupo, "os que mais se interessaram em desenhar foram os xamãs" [ANDUJAR, 2005, p. 109] - o que talvez decorresse do fato de serem eles os membros da aldeia mais acostumados a lidar com "imagens", embora de outra natureza, nos sonhos induzidos pela yãkoana.
A pesquisa foi bruscamente interrompida em 1977, com a expulsão da fotógrafa das terras yanomami pelo governo militar, que a enquadrou na Lei de Segurança Nacional, provavelmente por suspeitas de que suas imagens seriam utilizadas contra o regime. De volta a São Paulo, e revoltada com a expulsão da Amazônia, Andujar lançou-se firmemente na militância política, fundando, juntamente com Carlo Zacquini e o etnólogo francês Bruce Albert, a Comissão pela Criação do Parque Yanomami [CCPY], organização não-governamental que coordenou por mais de vinte anos. Também se dedicou à organização de seu amplo arquivo fotográfico yanomami, selecionando parte desse material para publicação. Yanomami: frente ao eterno e Amazôniavieram à luz nesse período.

Ambos os livros foram censurados pelo governo militar e, mesmo após o fim do regime, nunca chegaram a ser disponibilizados em livrarias, apenas em sebos. Segundo Andujar, transtornado com as duas censuras, José Regastein Rocha, diretor da Praxis, abandonou a empresa e, em seguida, a própria editora chegou ao fim [ANDUJAR, 2010, n.p.]. A raridade dos livros, sua qualidade artística e relevância na trajetória de Andujar fazem com que, atualmente, exemplares cheguem a atingir preços robustos em sebos virtuais. 
Yanomami: frente ao eterno foi o primeiro dos três livros ${ }^{5}$ lançados por Claudia Andujar em 1978. O volume, realizado em parceria com Darcy Ribeiro, inaugurava a série intitulada Memória Social da Editora Praxis, dedicada a tratar de "temas sociais brasileiros", segundo a editora [ANDUJAR, 1978 a, n.p.]. Nele, há a apresentação de Claudio e Orlando Villas Boas, além de textos de Andujar e Ribeiro, todos tocando, em maior ou menor grau, nas a meaças físicas e simbólicas a que estavam submetidos os Yanomami pelo recente contato com a sociedade dita civilizada. O livro é dedicado à memória do pai da fotógrafa - morto em campo de concentração nazista, assim como toda a sua família paterna, de origem judia -, e a experiência traumática da guerra surge pontualmente, em texto de sua autoria, relacionada ao desterro dos Yanomami: "[...] essa procura partiu de mim, de meu próprio sofrimento e vida, mas me ultrapassou e abarcou o destino de um povo, como o dos Yanomami, com o qual me identifiquei e cuja luta virou minha luta" [ANDUJAR, 1978 a, n.p.].

O projeto gráfico foi pensado pelo artista Wesley Duke Lee, com margens amplas e abundância de fundo branco [NOGUEIRA, 2018, p. 203]. Ao longo das páginas, trechos curtos sobre o cotidiano e a cosmovisão yanomami ocupam pequeno espaço em canto inferior de página majoritariamente branca, acompanhando e contextualizando uma imagem que geralmente se encontra na página ao lado. Cada fotografia situa-se no interior de um retângulo de linhas pretas muito finas, que Ihe serve de moldura e a faz flutuar no espaço. cria-se o ambiente propício para que o olhar se demore sobre as imagens em si, com rápidas digressões para as frases adjacentes [Fig.1].

As fotografias, todas em preto-e-branco, mostram partes de corpos yanomami: rostos [frente e perfil], seios, nuca, barriga grávida, dorso, torso, mãos, vagina, etc. Em meio aos fragmentos de corpos, alguns artefatos culturais são enfatizados: colares de miçangas, brincos de penas, braçadeiras, tangas femininas, cordões penianos, dentre outros. Ora as figuras aparecem sozinhas, ora em pares. As imagens são feitas a uma distância muito pequena dos retratados, fruto da intimidade que a artista havia desenvolvido com eles ao longo dos anos de convivência: às vezes, parece que podemos tocar um rosto, uma mão, uma barriga, uma nuca. Claudia nos deixa a sós com a intimidade de seus modelos em meio à imensidão branca da página. 


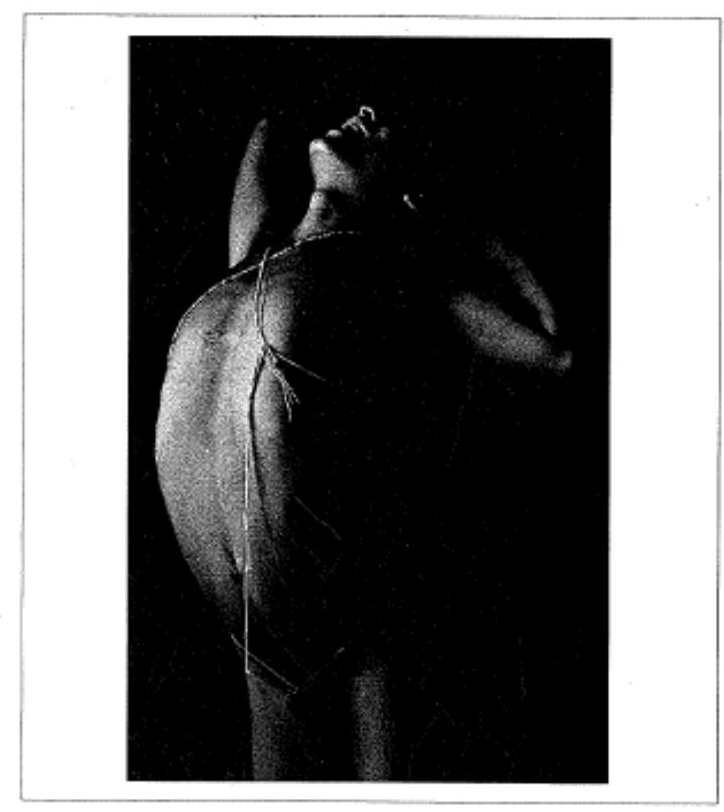

Fig. 1 - Página dupla de YANOMAMI: FRENTE AO ETERNO.

[Fonte: ANDUJAR, Claudia. YANOMAMI: FRENTE AO ETERNO. São Paulo: Práxis, 1978a.]

Segundo Thyago Nogueira [2018], as fotografias foram realizadas entre 1974 e 1976, fazendo uso apenas da iluminação natural no interior das malocas. Percebe-se, no entanto, que uma imagem foge a essa regra, denunciando o uso de flash, como veremos adiante. Nogueira ressalta que quase um filme inteiro era consumido em cada retrato, a fim de que fotógrafa e modelo pudessem aprofundar a intimidade ao longo dos cliques.
Em meio às trinta e oito fotografias do livro, apenas três aludem ao xamanismo. Elas se situam ao final do volume, como que à espera de que o espectador/ leitor adquirisse maior familiaridade com os Yanomami e seus artefatos antes de ser introduzido a um tema de maior complexidade. Na primeira das três imagens, um homem cobre a parte inferior do rosto com uma das mãos [Fig.2]. Os caminhos tremulantes de luz que o ladeiam sugerem que ele inala 
o psicoativo yãkoana e entra em contato com os xapirí [entidades que, para os Yanomami, são algo como espíritos da floresta], cuja presença na imagem justificaria os intensos contrastes claro-escuro em livro dominado pelas baixas luzes. Trata-se da única imagem do volume que atesta a presença de flash em sua construção. Em várias passagens do livro A queda do céu[2015], o xamã yanomami Davi
Kopenawa e o etnólogo Bruce Albert referem-se à visão da chegada dos xapiri como a aproximação de frenéticos caminhos de luz, que viriam ao encontro do xamã durante o transe. À medida que Andujar compreendia mais profundamente o universo xamânico, por meio de longas estadas na comunidade e do contato próximo com xamãs, passava a criar estratagemas técnicos que fizessem alusão a

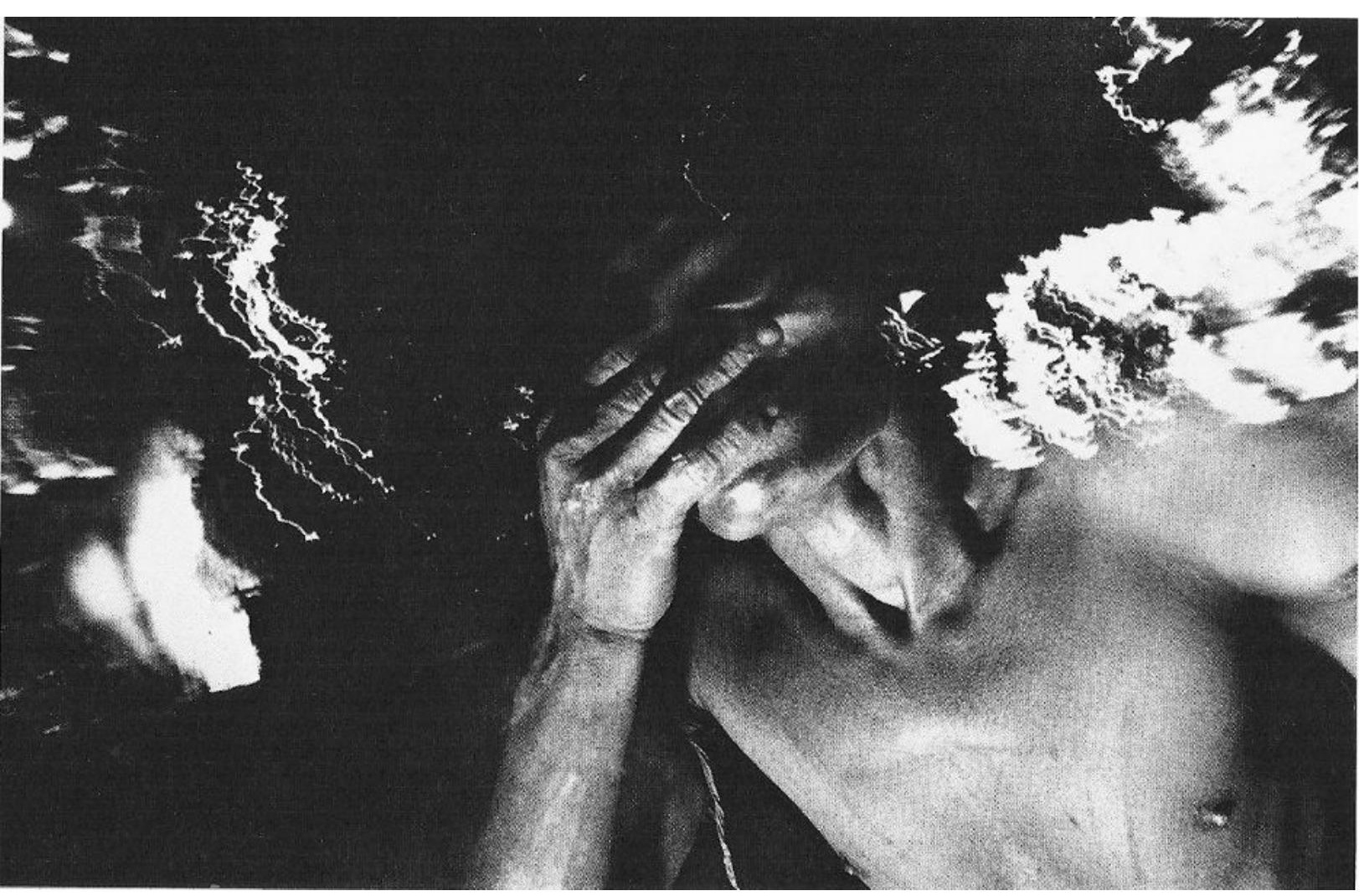

Fig. 2 - Claudia Andujar, Sem Título, 1974-1976. Fotografia.

[Fonte: ANDUJAR, Claudia. Yanomami: frente ao eterno. São Paulo: Práxis, 1978a] esse modo de conhecimento. A combinação de flash, longa exposição e movimento da câmera torna-se recurso largamente utilizado pela fotógrafa em imagens que abordam o xamanismo yanomami, evocando a presença e o deslocamento dos xapiri.

DE MORAES, Ana Carolina Albuquerque. Xamanismo em fołolivros de Claudia Andujar: Yanomami e Amazônia. 


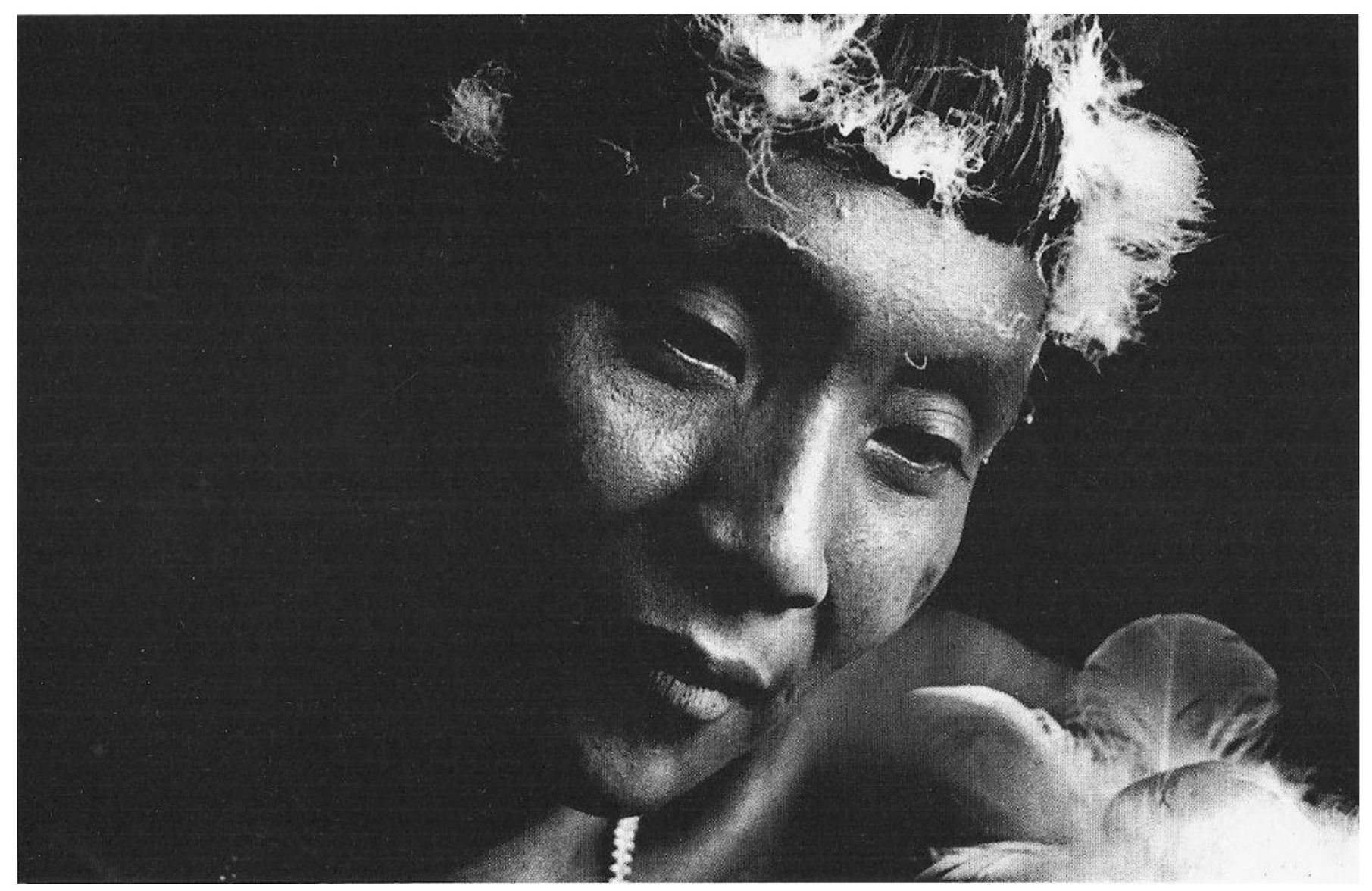

Fig. 3 - Claudia Andujar, Sem Título, 1974-1976. Fotografia.

[Fonte: ANDUJAR, Claudia. Yanomami: frente ao eterno. São Paulo: Práxis, 1978a]

Na fotografia seguinte, um rosto masculino, sutilmente emergido da escuridão, fita carinhosamente um adorno com plumas, provavelmente uma braçadeira, enquanto sua cabeça está enfeitada com penugens brancas [Fig.3]. O texto relacionado a essa imagem diz: "O adorno é mais que um enfeite, é uma identificação com o mundo espiritual" [ANDUJAR, 1978a, n.p.]. Os Yanomami enfeitam-se para receber os xapiri durante as festas reahu. Cada enfeite teria um respectivo correspondente no mundo invisível.

Revista Poiésis, Niterói, v. 23, n. 39, p. 224-252, jan./jun. 2022. [DOl: https://doi.org/10.22409/poiesis.v23i39.49154] 


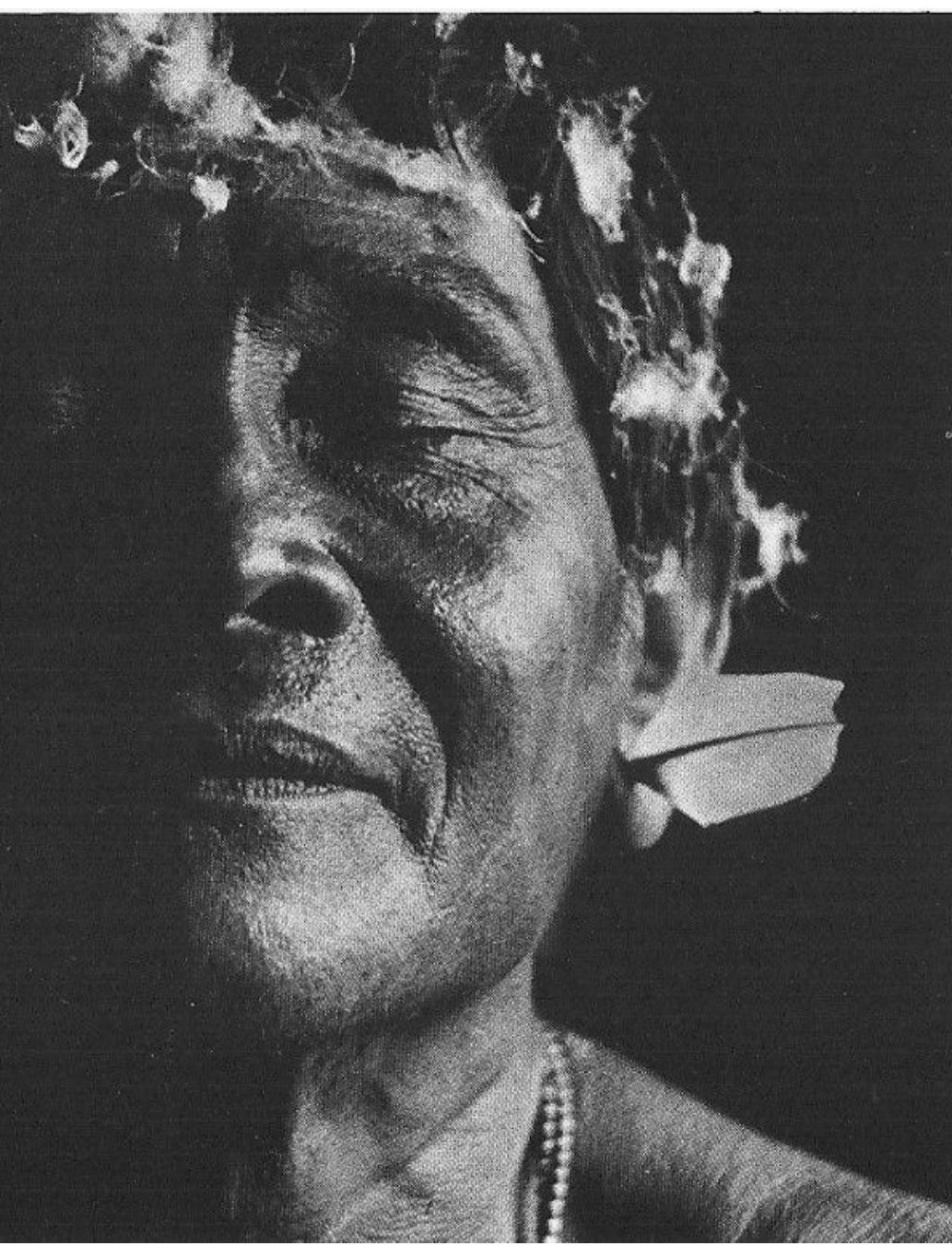

Fig. 4 - Claudia Andujar, Sem Título, 1974-1976. Fotografia.

[Fonte: ANDUJAR, Claudia. Yanomami: frente ao eterno. São Paulo: Práxis, 1978a] 
Descrevendo detalhadamente os xapiri, Kopenawa e Albert enfatizam todo o seu esmero com a aparência antes de virem ao encontro dos xamãs: pintam os corpos e enchem-se de adornos para causar deslumbre. "Tem um porte muito imponente! Foi Omama que os ensinou a se enfeitar assim. Quis que fossem magníficos para vir nos mostrar sua dança de apresentação", comentam os autores, referindo-se ao demiurgo yanomami [KOPENAWA; ALBERT, 2015, p. 112]. Nos braços, os xapiri levam "muitos penachos de penas de papagaio e caudais de arara fincadas em braçadeiras de belas miçangas lisas e coloridas, com muitas e muitas caudas de tucano e despojos multicolores de pássaros wisawisama sipendurados" [KOPENAWA; ALBERT, 2015, p. 112]. Bastante exigentes, os xapiri demandam que seus anfitriões terrenos estejam adornados à altura para recebê-los; caso contrário, podem desistir da visita. Na imagem, o olhar atento da figura para o adorno parece evocar seu apreço pelos significados do objeto.

A penúltima imagem do livro mostra a metade esquerda do rosto de um homem maduro, a outra metade diluindo-se na escuridão [Fig.4]. Com os olhos fechados e o semblante sereno, usa brinco de pena e penugens brancas sobre a cabeça. Os adornos e a expressão tranquila, os olhos fechados sugerindo sono profundo, fazem-nos pensar em um xamã experiente em contato com os xapiridurante seus sonhos.

Apenas a fotografia seguinte, última do livro, faz referência ao contato com os brancos, como que a lembrar, após o êxtase xamânico, que aquela organização social se encontrava ameaçada pela chegada de invasores e seus signos. Um Yanomami é retratado do peito para cima com camiseta listrada e mão sobre o queixo, em pose comum a modelos ocidentais masculinos. Ao lado da imagem, o pequeno trecho textual constata a mudança e sutilmente a lamenta: "Um novo mundo abriu-se aos seus olhos. Ele é um ESTRADATHERI, morador da estrada" [ANDUJAR, 1978a, n.p.; grifo no original], em referência à construção da rodovia Perimetral Norte, que atraiu alguns grupos Yanomami para a vida às margens da estrada, mesmo após o abandono das obras, em 1976 [NOGUEIRA, 2018]. Em texto na sobrecapa do volume, Andujar explicita sua preocupação: "Nos limites da ética tribal, há uma margem grande de tolerância para o não convencional e eles se adaptam com facilidade ao novo; por isso, são vulneráveis a uma desaculturação7 rápida que pode se tornar extremamente perigosa" [ANDUJAR, 1978a, n.p.].

Em consonância com o tom de denúncia dos textos, há, nas últimas páginas, um desenho e um texto atribuído ao xamã Wárasi Hwayautheri, com 
quem Andujar desenvolveu forte amizade [ANDUJAR, 2005, p. 119]. No texto, intitulado Os espíritos do xamã abandonado, Wárasi lamenta a perda de confiança em si mesmo e seus poderes, já que não teria conseguido livrar seus parentes da morte [em virtude das epidemias contraídas dos trabalhadores da estrada]. Atribui sua incapacidade à partida da maior parte de seus espíritos auxiliares [xapiri], que teriam retornado às suas casas, no topo das montanhas. O texto termina com a declaração cética e dolorosa: "Não sou mais xamã" [HWAYAUTHERI, In: ANDUJAR, 1978a, n.p.].

Apesar desse texto, o xamanismo é abordado com discrição em Yanomami: frente ao eterno. Andujar introduz sutilmente o espectador/leitor ao tema, em poucas imagens. Não é tema forte no livro, que imageticamente se foca nos retratos e fragmentos de corpos e artefatos, enquanto textualmente prioriza a denúncia das consequências nocivas do contato entre os Yanomami e a sociedade externa.

\section{AMAZÔNIA}

Se Yanomamié sóbrio, quanto às imagens e à diagramação, folhear Amazônia [ANDUJAR; LOVE, 1978] é uma experiência de abundância em vários aspectos: de paisagens, de efeitos fotográficos, de quantidade e tamanho das imagens reproduzidas. O projeto gráfico é do mesmo Wesley Duke Lee, que dessa vez, dado o tema e a natureza das imagens, enveredou por caminhos diversos: margens externas, superiores e inferiores estreitas, emoldurando as fotografias, e ausência de margens internas, resultando em pouco espaço em branco na quase totalidade das páginas.

O livro não apresenta texto, apenas fotografias em cores de Andujar e Love. Em projeto anterior, de 1973, o volume deveria conter quarenta páginas de texto, além de cento e quarenta e quatro de fotografias. Essa versão não teria vingado em virtude do alto custo do exemplar e de divergências entre autores e editor. O livro foi publicado, em diferente configuração, em 1978, também pela Praxis. A editora havia planejado a inclusão de um único texto no volume, encomendado por Regastein Rocha ao poeta amazonense Thiago de Mello, que acabava de retornar ao Brasil após exílio político [ANDUJAR, 2010]. Pelo teor das críticas ambientais do poeta, no entanto, o texto não passou pela censura dos militares, e o livro acabou por ser publicado apenas com imagens [NOGUEIRA, 2018, p. 206].

Segundo Thyago Nogueira [2018], Love foi o principal idealizador do volume. Queria ele que, por meio das imagens, a publicação abordasse, com igual nível de importância, o tema "Amazônia" e o meio fotográfico: a região amazônica sendo mostrada em fotografias que eram, em si, construções 
da realidade. A ideia da fotografia como artifício - construção em vez de "espelho" - é fortemente ressaltada no livro. Embora as imagens descortinem as dimensões gigantescas e certas particularidades paisagísticas e humanas da Amazônia, os autores não nos deixam imergir simplesmente no assunto. Somos constantemente lembrados de que estamos diante de imagens, com elevado grau de pensamento construtivo. Assim, as pontas de negativos fotográficos reproduzidas na abertura e no fechamento da sequência imagética - e que ressurgem em páginas intermediárias - lembram-nos continuamente de que, entre nós espectadores e as realidades mostradas nas imagens encontra-se, invariavelmente, o filme fotográfico. O mesmo ocorre quando nos deparamos com margens de fotogramas impressas nas páginas. Talvez pelo mesmo motivo, as imagens, embora reproduzidas quase do tamanho do formato da página, não "sangrem", não alcançando as bordas do papel. Emoldurando as fotografias, há margens que, embora estreitas, não nos deixam esquecer de que estamos diante de recortes, artificialmente construídos, da realidade.

Um depoimento de Love é particularmente elucidativo a esse respeito:

Na verdade, o livro surgiu das convicções sobre a natureza da fotografia e sobre a experiência na região, numa tentativa de conciliar ideias desses dois universos.
A Amazônia era o tema, mas o objetivo era mostrar que uma foto não é uma representação fiel do assunto. $\bigcirc$ livro foi construído para traduzir esta tese, de que aquilo que a fotografia mostra é uma impressão da realidade, apenas a minha impressão. $\bigcirc$ que você vê é a foto da floresta, não a própria. Não é o céu que você vê, é o filme. Não é um livro da Amazônia, é um livro de filmes. O livro nunca foi entendido. Também, ele foi simplesmente banido, na época áurea da censura. Nunca chegou ao público. Tiraram o texto. Achávamos suficiente o leitor ter uma introdução poética da recriação de atmosfera para estar preparado a se lançar nas imagens, onde a atmosfera, e não a fidelidade a um assunto, era o objetivo [LOVE, apud NOGUEIRA, 2018, p. 205].

Quanto à materialidade da imagem e aos jogos visuais envolvidos, Amazônia faz uso abundante de texturas, repetições, espelhamentos e sequências. Há fartura de texturas diversas, em motivos que muitas vezes não se deixam reconhecer, mas que certamente nos introduzem a certa "atmosfera" amazônica, como Love queria. Por essa valorização da materialidade dos elementos, Amazônia torna-se um livro intensamente tátil, embora por recursos puramente bidimensionais. O uso de repetições é também frequente. Muitas fotografias são reproduzidas mais de uma vez, ou de maneira idêntica ou, como é mais frequente, com tratamentos diferenciados - espelhamentos, rotações, novos enquadramentos e intervenções de luz, etc. -, de modo a nos lembrar, uma 
vez mais, sobre a materialidade e o caráter de invenção da imagem fotográfica.

As imagens não são individualmente assinadas, embora saibamos que as fotografias aéreas são atribuídas a Love - que, por ser asmático, não podia ficar longos períodos na umidade da floresta -, e que as fotos de Yanomami foram realizadas por Andujar. Aproximadamente até a metade, o livro é dominado por fotografias aéreas, que exploram variadas texturas - de nuvens, água, rochas, solos, copas de árvores - e nos dão ideia da magnitude da região. Uma ponta de filme marca o intervalo e nos direciona a uma escala terrena, na qual novamente nos deparamos com águas e plantas, porém a partir de um ponto de vista mais horizontal. Da escala macro das paisagens vistas de cima, passamos à escala micro de texturas de folhas, por exemplo. É nesse momento que somos introduzidos às fotografias de Yanomami.

Eles surgem sorrindo, brincando e descansando em redes, descontraídos em sua vida cotidiana. Em páginas duplas, Claudia explora sequências, como duas fotografias de uma mesma pessoa ou dupla em momentos subsequentes, para transmitir a ideia do fluxo contínuo do tempo na vida tranquila de Yanomami isolados. Há também paralelismos, como, numa página dupla, duas fotografias de pessoas em redes - uma moça à esquerda, um garoto à direita -, sem necessariamente nenhuma relação anterior à justaposição das imagens. Há ainda muitas pausas, que ajudam a dirigir o olhar para a imagem da página ao lado. Na imensidão de uma página dupla, por exemplo, olhamos especificamente para a pequena folha amarela mostrada por uma moça que brinca de esconder-se atrás dela.

Novamente, como última sequência do livro, deparamo-nos com imagens de reahue xamanismo. São dezesseis páginas duplas, de um total de setenta e seis com imagens no volume. Mais uma vez, a margem impressa de um fotograma indica a pausa e a passagem para o novo tema. Diferentemente do restante do livro, predomina nessa sequência a exposição de uma imagem figurativa por página dupla, a outra página contendo foto não figurativa, apenas com manchas de luz, exibindo às vezes a margem do fotograma. São dez páginas duplas com essa configuração, contra seis mostrando uma imagem figurativa em cada página simples. Provavelmente pelo caráter, em certa medida, secreto desses rituais, e pela profunda entrega emocional das pessoas que deles participam, os autores optaram por mostrar aos poucos as imagens que os abordam, intercaladas por longas pausas que, em alguns momentos, parecem solicitar do espectador o silêncio e a reverência, e, em outros, parecem evocar sensações e visões xamânicas durante o transe. 
A sequência começa com o rosto de um garoto de olhos fechados e segue para uma imagem em que três pessoas agachadas, provavelmente um xamã em primeiro plano, têm posturas e expressões que acusam o uso recente da yãkoana. Na próxima página dupla, à direita, dois homens abraçados parecem cantar e dançar, um deles com penugens brancas sobre a cabeça [Fig.5, em cima]. Ao redor do par, vemos timidamente os ondulantes caminhos de luz que Andujar usa para evocar a chegada dos xapiri, baseada em relatos dos próprios Yanomami sobre a configuração desse evento em suas visões xamânicas. Enquanto isso, a página à esquerda mostra listras verticais em diferentes tonalidades de amarelo, uma delas misturando-se ao vermelho. Os amarelos contrastam veementemente com o fundo negro e as baixas luzes predominantes na imagem à direita.

Relatando o processo de iniciação xamânica do primeiro, Kopenawa e Albert [2015] contam que, após a inalação da yãkoana, a imagem do corpo do xamã foi levada pelos xapiripor alturas e profundidades longínquas, voando muito acima das montanhas e abaixo da superfície da terra. Num dado momento, sua visão de sonho foi dominada por uma claridade ofuscante: uma luz intensa espalhou-se por toda parte, não mais the deixando reconhecer qualquer motivo. Tal experiência luminosa foi-Ihe decisiva para compreender que, naquele momento, tornava-se outro, assumia a perspectiva de outrem - a dos xapiri -, conforme será discutido mais adiante.

Viveiros de Castro [2006] lembra que, entre os povos ameríndios da Amazônia, é frequente a associação da percepção luminosa intensa demais à aproximação dos espíritos. Ponderando que tal visão de claridade absoluta pode estar associada à ingestão de psicoativos, como a yãkoana, surgindo como efeito bioquímico, afirma que tal explicação, obviamente, não é válida nas cosmovisões ameríndias, para as quais tais substâncias são canais que permitem a conexão com o mundo invisível, por onde os xamãs transitam a fim de descobrir a ampla rede de intencionalidades subjacente ao mundo visível. De modo poético, o autor relaciona a invisibilidade dos espíritos para as pessoas comuns à sua altíssima frequência luminosa, que estaria situada acima do espectro visível: um "caráter super-visível" distinguiria esses seres [VIVEIROS DE CASTRO, 2006, p. 332]. Na imagem em questão, é possivel pensar que os homens abraçados, empoderados pela yãkoana, tenham acesso, em seus sonhos, à claridade ofuscante dos xapiri.

O ápice desse raciocínio parece surgir na página dupla seguinte, uma das mais impressionantes [Fig.5, embaixo]. Na página à esquerda, as linhas 
de luz branca assumem tamanhas densidade e espessura que chegam a tornar-se verdadeiras massas de luz, riscos concentrados meio amorfos cuja gestualidade orgânica talvez lembre uma action pain-

ting, agora inscrita com luz. Os riscos invadem e cortam a composição com voracidade tal que, da pessoa retratada, distinguimos apenas os olhos, perdidos em meio à potência da luz branca. A página à direita é de um branco ofuscante quase total, maculado apenas por uma oscilante linha preta amarelada que o corta verticalmente. Os xapiri andujarianos parecem assumir aqui, quase, o tal "caráter super-visível".

Fig. 5 - Páginas duplas de Amazônia.
Em algumas páginas duplas, uma das metades é ocupada por fotografia em que não se reconhece motivo algum, apenas luzes difusas como que remetendo a visões durante intensa vertigem [Fig. 6] .
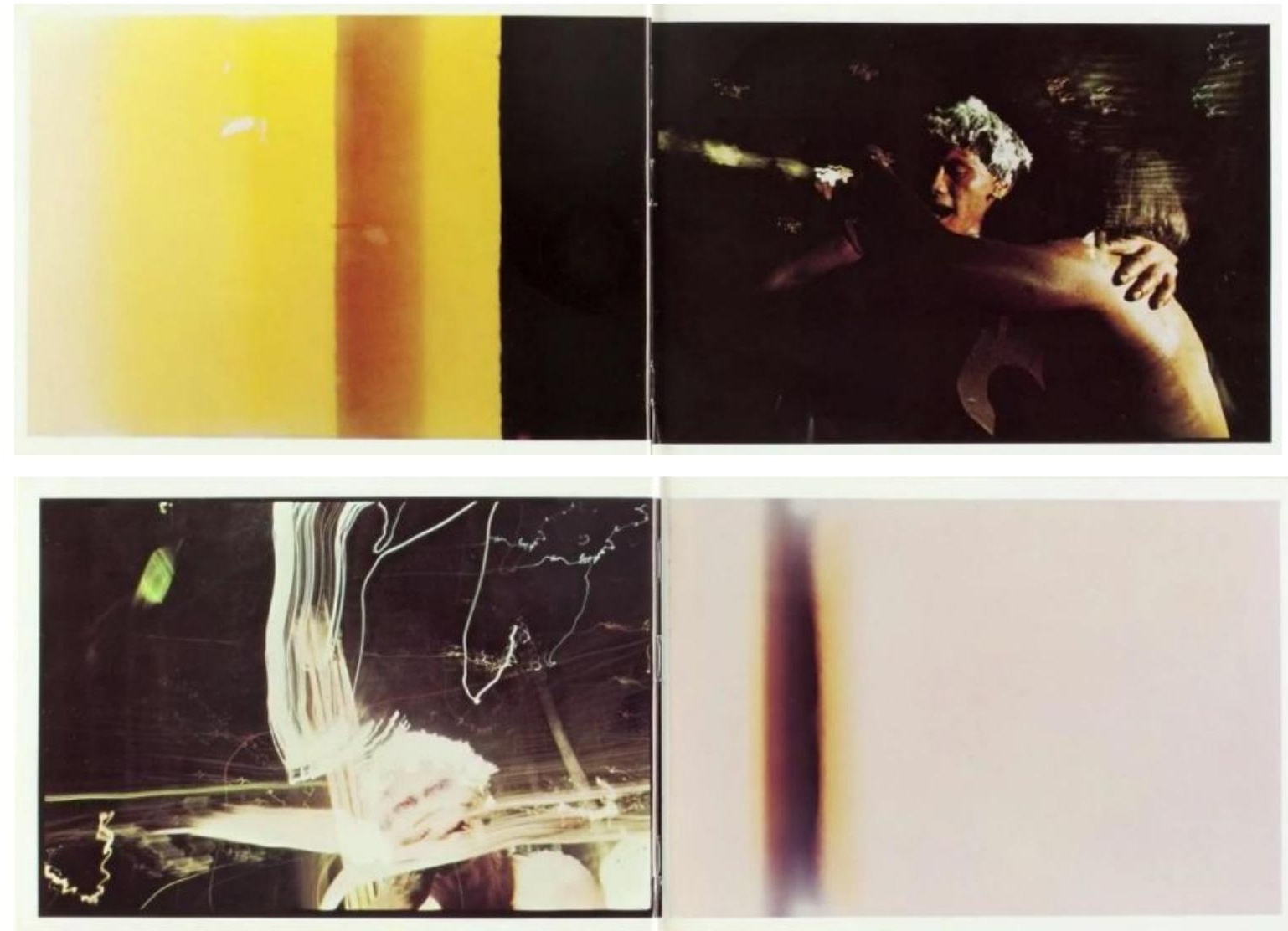

[Fonte: ANDUJAR, Claudia; LOVE, George. Amazônia. São Paulo: Praxis, 1978] 

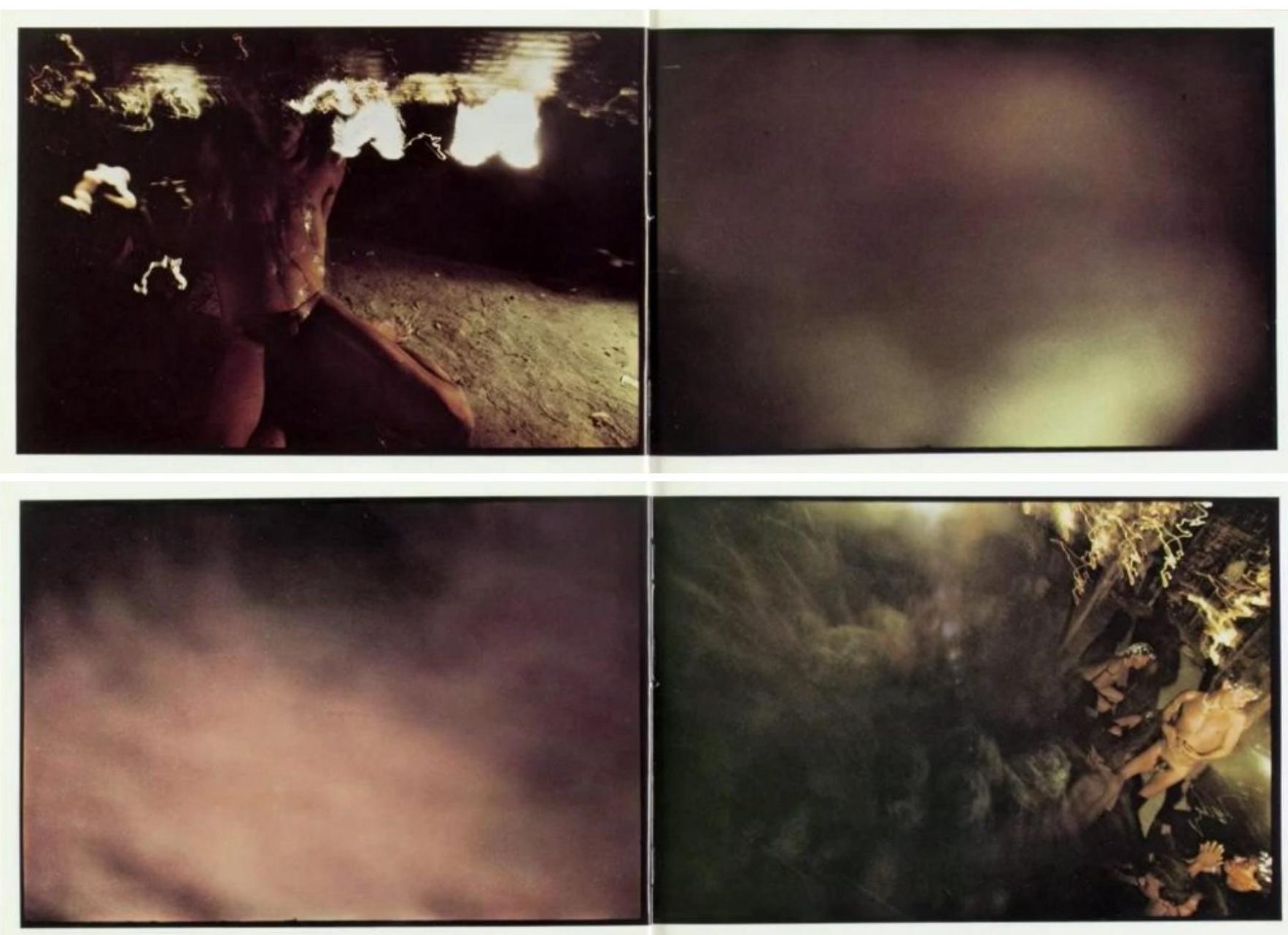

Fig. 6 - Páginas duplas de Amazônia.

[Fonte: ANDUJAR, Claudia; LOVE, George. Amazônia. São Paulo: Praxis, 1978]

Numa delas, um rapaz sentado sobre os joelhos, com o corpo molhado de suor e saliva é rodeado por manchas de luz branca amarelada, evocando a aproximação do xapiri. A página ao lado, coberta por manchas difusas de luz, parece aludir à sensação de vertigem após a inalação da yãkoana. Em outra dupla de páginas, algumas pessoas, em escala pequena, são vistas em diagonal próximas Revista Poiésis, Niterói, v. 23, n. 39, p. 224-252, jan./jun. 2022. [DOl: https://doi.org/10.22409/poiesis.v23i39.49154] 
à margem direita. Acima delas, impõem-se frenéticos caminhos de luz amarela. Esse pequeno conjunto ocupa menos de um terço da página, enquanto o restante é ocupado por massas amorfas de luz, resultantes do desfoque total dos motivos. Na página à esquerda, as manchas são ainda mais difusas, carecendo de qualquer referência a dados da realidade externa.
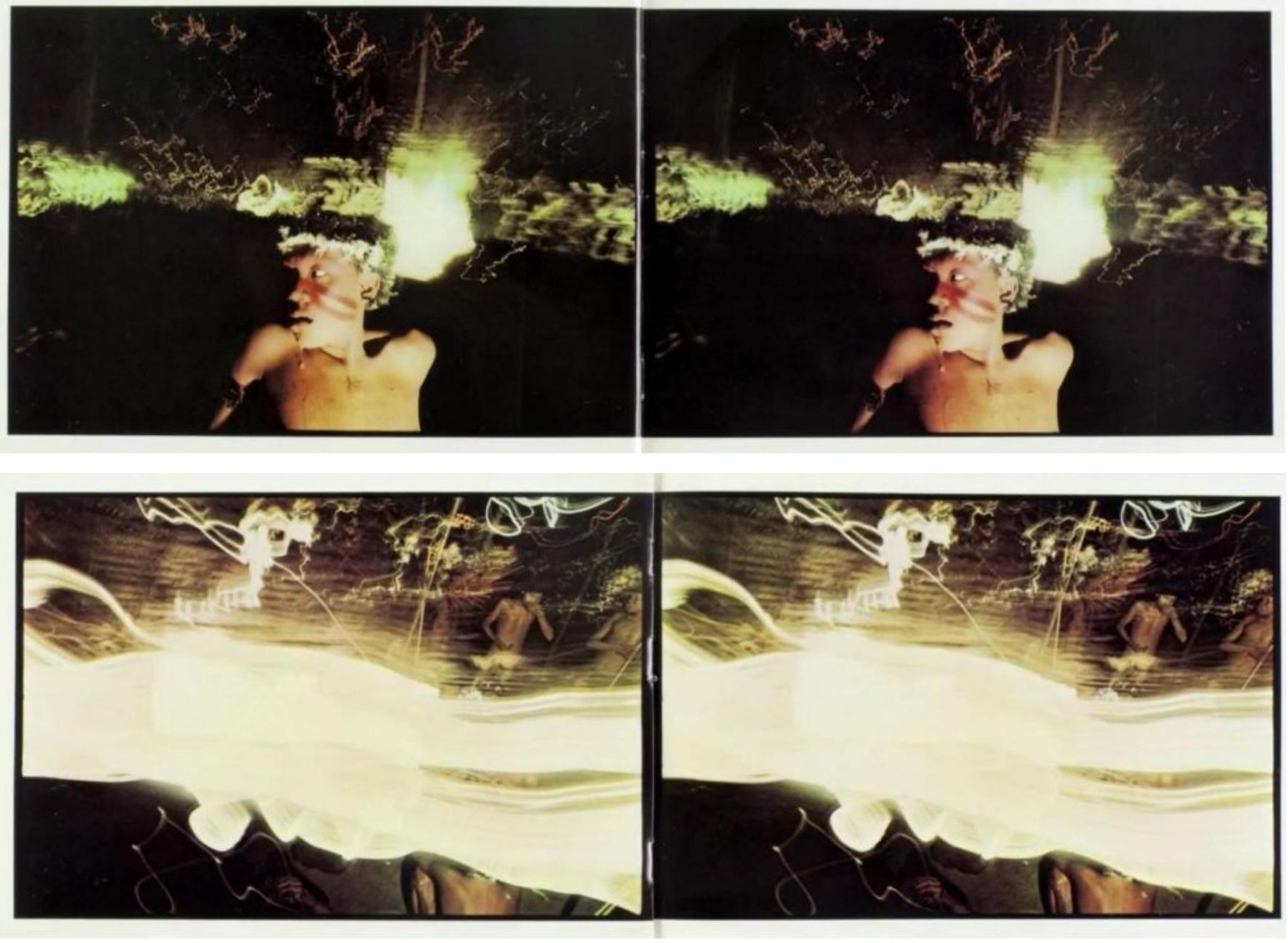

Fig. 7- Páginas duplas de Amazônia.

[Fonte: ANDUJAR, Claudia; LOVE, George. Amazônia. São Paulo: Praxis, 1978]

DE MORAES, Ana Carolina Albuquerque. Xamanismo em fotolivros de Claudia Andujar: Yanomami e Amazônia. 
Das páginas duplas que contêm imagens figurativas em ambos os lados, algumas apresentam fotografias identicamente duplicadas, o que pode aludir à visão multiplicada dos xamãs durante o transe [Fig.7]. Numa delas, um rapaz retratado do tórax para cima volta a cabeça e o olhar para um lado. Do nariz e da boca, escorrem muco e saliva, reação que comumente se segue à inalação da yãkoana. Por trás da cabeça, distribuem-se os frenéticos caminhos ondulantes de luz, sobretudo ao longo de uma linha horizontalizada. Em outra dupla de páginas, tais caminhos avolumam-se a tal ponto que se transformam em massa muito espessa de luz branca, que, em primeiro plano, corta horizontalmente a imagem, deixando atrás de si minúsculos elementos humanos. Os corpos, proporcionalmente pequenos, parecem aludir à submissão do homem à onipresença desse mundo sobre-humano, que pulsa por trás das a parências a reger e organizar a vida humana.

Em duas páginas duplas já mostradas [Figs. 6 e 7, embaixo], a posição da fotógrafa, que capta a cena de cima, parece sugerir uma troca de ponto de vista, na acepção do perspectivismo ameríndio de Viveiros de Castro [1996] e Tânia Stolze Lima [1996]. Segundo essa teoria, para os ameríndios, uma ampla gama de seres no universo é dotada de humanidade e agência: o que é ou não humano depende do ponto de vista de quem está na posição de sujeito. No passado absoluto, descrito pela mitologia, todos os seres eram humanos, cultural e morfologicamente, e a possibilidade de metamorfose entre eles era virtualmente infinita. Com o passar dos tempos, alguns perderam a forma humana, transformando-se em animais, vegetais, etc., preservando, porém, o espírito humano. A perda da unidade primordial e a diferenciação das espécies deu origem às múltiplas perspectivas. Embora o espírito humano permaneça transespecífico, cada corpo carrega consigo uma perspectiva única, um ponto de vista singular, irredutivelmente inscrito naquele corpo e apenas possível a partir dele. Oxamã, enquanto diplomata cósmico, consegue transitar entre as perspectivas, assumindo diferentes pontos de vista sem deixar de retornar ao seu próprio. Diferentes pontos de vista não significam diferentes representações sobre o mundo, mas sim, necessariamente, diferentes mundos: cada mundo só existe na perspectiva de quem está na posição de sujeito, não havendo a "coisa em si". O perspectivismo ameríndio é, assim, amplamente relacional, e as relações predador-presa constituem campo altamente propício para as inversões perspectivas. Por exemplo, "os animais predadores e os espíritos [...] veem os humanos como animais de presa, ao passo que os animais de presa veem os humanos como espíri- 
tos ou como animais predadores" [VIVEIROS DE CASTRO, 2002, p. 350]. Os espíritos, em particular, jamais viram presa: seu ponto de vista é sempre dominante. "[...] o que define os espíritos é, entre outras coisas, o fato de serem supremamente incomestíveis; isso os transforma em comedores por excelência, ou seja, em antropófagos" [VIVEIROS DE CASTRO, 2002, p. 392-393].

Nas imagens em questão, a fotógrafa parece assumir o ponto de vista privilegiado dos espíritos: de cima e de longe, visualiza os seres humanos como minúsculas criaturas, sem ser vista de volta por eles. Aliás, como reiteradamente afirmam Kopenawa e Albert [2015], os xapiri, em sua visão onipotente, veem sempre os humanos, mas apenas os xamãs são capazes de vê-los em contrapartida-e sob muitas condições. São os xapirique decidem para quais xamãs tornar-se-ão visiveis - aqueles que houverem cumprido todas as suas exigências de hábitos alimentares e comportamentais. A fotógrafa-xapiri parece, então, assumir momentaneamente a perspectiva daquele que pode ver sem ser visto, devorar sem ser devorado, detendo sempre o ponto de vista dominante.

Às vezes, a migração da consciência e o acesso a visões de outra natureza são associados a níveis de desconstrução da própria imagem fotográfica, ressaltando sua materialidade e criando laços de aparência com a pintura informalista. Numa sequência, um homem posiciona logo abaixo do nariz o utensílio pelo qual se sopra e inala yãkoana [Fig.8]. Andujar realiza intervenções de luz que se superpõem à parte de cima da cabeça do modelo, chegando até a cobri-la como um todo, como que a sugerir o acesso a outro patamar da consciência. As manchas de luz, ora brancas, ora rosadas, muito espessas e com alto grau de opacidade, chegam a lembrar manchas de tinta numa pintura abstracionista, aproximando - em termos de resultado, não de processo - a fotografia de Andujar da visualidade pictórica.

O ápice dessa relação parece surgir na sequência em que uma urna funerária na floresta, fotografada com filtro infravermelho de um ponto de vista rebaixado, transforma-se, na dupla seguinte de páginas, em manchas e riscos vermelhos e amarelos sobre fundo em que a referência à floresta é apenas uma evocação distante [Fig.9]. Os vermelhos que, na fotografia de origem, lembram sangue, fogo e morte parecem, nas páginas seguintes, levar esses significados ao paroxismo e, contraditoriamente, esvaziá-los na materialidade da imagem. 

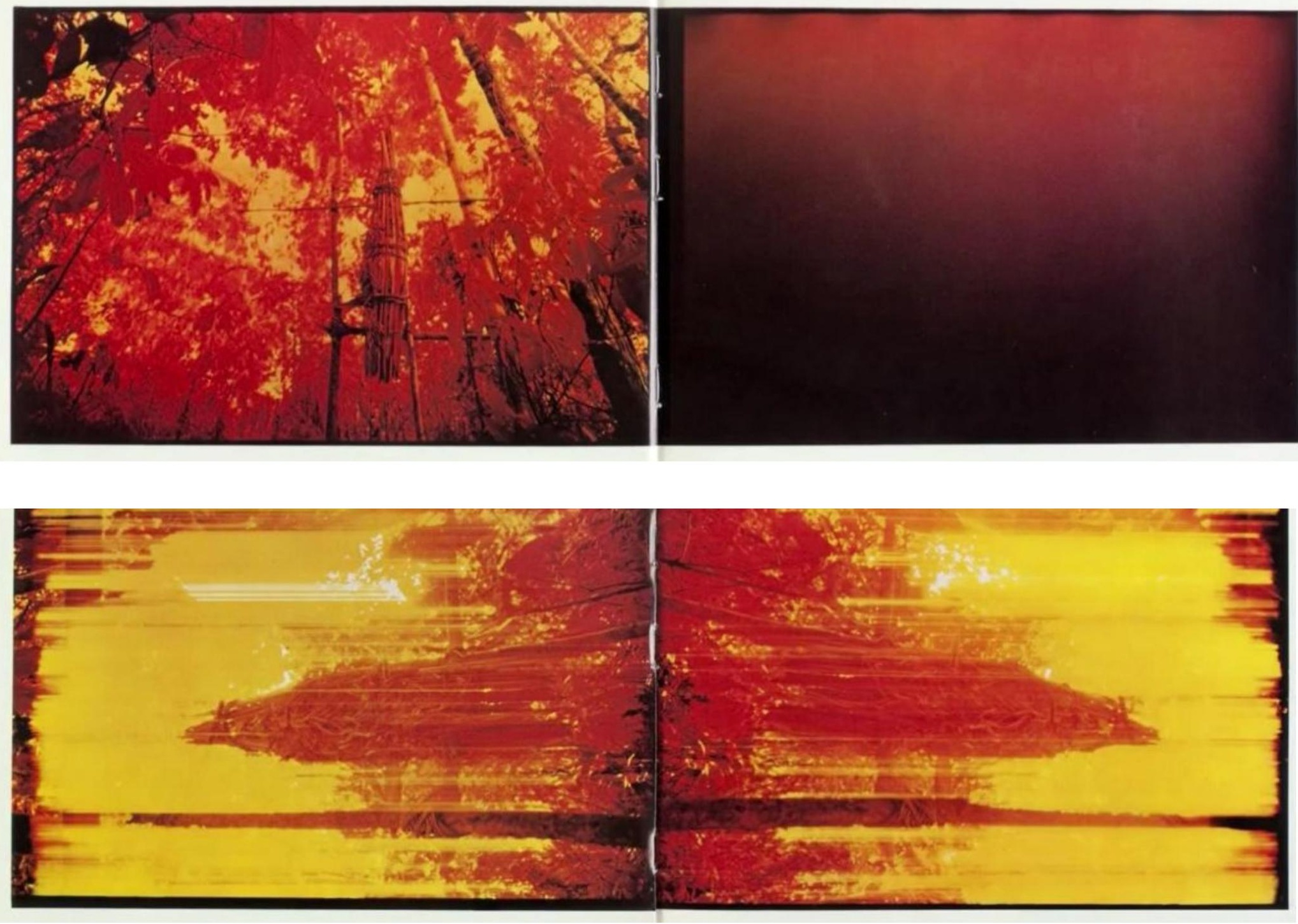

Fig. 9 - Páginas duplas de Amazônia.

[Fonte: ANDUJAR, Claudia; LOVE, George. Amazônia. São Paulo: Praxis, 1978]

DE MORAES, Ana Carolina Albuquerque. Xamanismo em fotolivros de Claudia Andujar: Yanomami e Amazônia. 


\section{CONSIDERAÇÕES FINAIS}

Yanomami, preto-e-branco, é sóbrio, sutil, objetivo. Sua poesia reside justamente na simplicidade plástica e projetual, na singeleza dos motivos, na visualidade franca e sugestiva. A fotógrafa encontra-se sempre na altura do retratado, dialogando de perto com seus modelos. Os enquadramentos fechados e a luz que acaricia delicadamente os corpos revelam apenas partes: o discurso é metonímico. O que vemos são fragmentos de corpos emergindo da escuridão: a negritude do fundo não nos permite a contextualização do espaço. Predominam os suaves contrastes claro-escuro, a luz viscosa que avoluma e, sutilmente, revela. Uma única imagem traz o brilho ofuscante dos xapiri, e os contrastes explodem para dar conta do assunto.

Já Amazônia, em cores, é exuberante, tátil, imprevisível. Sua poética é a do deslumbramento, da surpresa. "O que é isso?", perguntamo-nos inicialmente, apenas para nos darmos conta de que o "isso" não importa tanto; mais decisivas são as diversas sensações que nos transmitem as imagens, a tal "atmosfera" a que Love aludiu. Muito mais que registros de uma realidade exterior, as fotografias se pretendem construções de realidades possíveis. Assim como em Yanomami, o projeto gráfico é marcado pela simplicidade; a diferença fica por conta da natureza e das dimensões das imagens: a página dupla vista como um todo, sem margens internas, chega a lembrar a vastidão da tela de cinema. As posições dos fotógrafos são múltiplas: ora as vistas aéreas de Love, ora a relação horizontal de Andujar com os modelos, ora a vista de baixo que amplifica urna funerária e floresta. Em contraponto à visualidade franca de Yanomami, há aqui uma poética de recursos visuais múltiplos, de modo a evidenciar, continuamente, o pensamento técnico e construtivo da imagem fotográfica.

Enquanto Yanomamiapenas de leve toca no tema do xamanismo, Amazônia aborda-o fartamente, tanto em relação à quantidade e às dimensões das imagens como quanto à variedade de efeitos visuais utilizados. Em vários momentos, a câmera parece transformar-se em pincel, desenhando e pintando com a luz: a reprodutibilidade técnica sugerindo a gestualidade orgânica da mancha e do traço, a fotografia em diálogo com a introspecção de um Rothko, a catarse de um Pollock. Ora se evoca o deslocamento dos xapiri, ora a migração da consciência no transe xamânico, ora outros significados nunca esgotáveis. Esse desenhar e pintar com a câmera só é possível por meio de intensa experimentação técnica e exímio conhecimento das possibilida- 
des da fotografia analógica. Como sugeriu Love, era preciso conhecer bem as duas realidades: a amazônica e a fotográfica. No caso de Claudia, o conhecimento da realidade amazônica focava-se decisivamente na compreensão cultural dos Yanomami. O experimentalismo técnico buscava dar forma a seus conhecimentos etnológicos.
NOTAS

1 Além dos já citados artigos de minha autoria, frutos da pesquisa de doutorado em andamento, artigos recentes de outros autores também tecem relações entre obras de Andujar e o xamanismo yanomami [DUARTE, 2003; CASTANHEIRA, 2016; HATA, 2018; ANDRADE NETO, 2018; GARCEZ, 2020; CABRAL; MEDEIROS, 2020].

2 A pesquisa está sendo desenvolvida junto ao Programa de Pós-Graduação em Artes Visuais da Universidade Estadual de Campinas, sob orientação da Profa. Dra. Maria de Fátima Morethy Couto. Sou grata à Profa. Dra. Ilana Seltzer Goldstein, do Programa de Pós-Graduação em História da Arte da Universidade Federal de São Paulo, pelas valiosas contribuições, referentes ao campo da Antropologia, durante meu exame de qualificação. Agradeço também à Galeria Vermelho, nas pessoas de Jan Fjeld e Marcos Gallon, pelas entrevistas concedidas e os documentos disponibilizados.

3 A substância a que os Yanomami denominam yãkoana origina-se da pulverização da resina obtida, por exsudação, de tiras da casca da árvore Virola elongata [yãkoana hi]. Os xamãs - e demais membros da comunidade do sexo masculino - inalam o pó de yãkoana por meio de um tubo de madeira [horoma], posicionando a narina numa extremidade, enquanto o pó é soprado com força por alguém situado na outra [ALBERT; MILLIKEN, 2009].

4 Entre o povo Yanomami, o xamanismo é praticado pela quase totalidade dos homens de uma aldeia, sendo considerado uma etapa importante na formação de um homem adulto [TAYLOR, 1996; RAMALHO, 2008]. Apesar disso, o prestígio daqueles identificados pelo grupo como "xamãs" advém do fato de apenas eles serem considerados capazes de solucionar 
as querelas mais difíceis. $\bigcirc$ xamã yanomami passou necessariamente por uma iniciação dolorosa, repleta de esforço e privações, e dedicou/dedica muito mais tempo da sua vida à aprendizagem de cantos xamânicos, à inalação da substância psicoativa e ao contato com espíritos auxiliares durante o transe induzido por essa substância. Quanto mais experiente o xamã, maior a quantidade e a variedade de espíritos que atendem aos seus chamados, espíritos dos quais ele pode lançar mão durante as sessões xamânicas, a fim de solucionar os mais diversos obstáculos na comunidade [KOPENAWA; ALBERT, 2015].

5 Em 1978, Andujar lançou, além dos dois livros analisados neste artigo, a obra que levava a público os resultados da pesquisa da FAPESP: Mitopoemas Yãnomam, publicada pela Olivetti do Brasil S.A., em edição trilíngue [português-italiano-inglês], com introdução de Pietro Maria Bardi [ANDUJAR, 1978b]. 6 Termo que, para os Yanomami, designa entidades, normalmente invisíveis, que se encontram por toda parte, observando e regulando a vida terrena. Cada ser florestal possui um respectivo xapiri, que the corresponde no mundo invisível. Todos os xapiri apresentam morfologia humanoide, aludindo a um passado primordial em que todos os seres eram humanos, não havendo diferenciação entre espécies [KOPENAWA; ALBERT, 2015].

$7 \bigcirc$ termo "desaculturação" é aqui utilizado como sinônimo de "aculturação". Segundo a teoria antropológica da aculturação, o contato prolongado entre culturas distintas torna-as cada vez mais semelhantes, numa interinfluência mútua que pode levar à fusão entre elas [GOW, 2015, p.35-37]. O antropólogo Darcy Ribeiro, parceiro de Andujar, preferia falar em "transfiguração étnica": "um processo natural, cultural [...] através do qual um povo permanece ele mesmo à medida que muda e se adapta às condições de sobrevivência. Trata-se de um processo de autoconservação em que eles vão conservando o que é possível de sua cultura, mas não se fecham" [RIBEIRO, apud GRUPIONI; GRUPIONI, 1997, p. 191]. 
ALBERT, Bruce; MILLIKEN, William. Urihi a: a terra-floresta Yanomami. São Paulo: Instituto Socioambiental [ISA]; Institut de Recherche pour le Developpement [IRD], 2009. Disponivel em https://acervo. socioambiental.org/acervo/publicacoes-isa/urihi-terra-floresta-yanomami. Acesso em 20 nov. 2020.

ANDRADE NETO, Alberto Luiz de. Brilho e sonhos: caminhando com Andujar, Kopenawa e Albert. REIA, ano 5, v. 5, n. 1, p.5-27, 2018. Disponível em https://periodicos.ufpe.br/revistas/reia/article/ view/236427. Acesso em 15 jun. 2021.

ANDUJAR, Claudia. Depoimento sobre a série Sonhos Yanomami. [2005?]. Documento digital contendo 1 página. Acervo Galeria Vermelho.

ANDUJAR, Claudia. Entrevista a Rubens Fernandes Jr., durante o 2. Fórum Latino-americano de Fotografia de São Paulo, ocorrido no Itaú Cultural. São Paulo, 24 de outubro de 2010, n.p. Disponível em http://docplayer.com.br/10422408-2-forum-latino-americano-de-fotografia-de-sao- paulo-rubens-fernandes-jr-entrevista-claudia-andujar.html. Acesso em 22 out. 2019.

ANDUJAR, Claudia. Mitopoemas Yãnomam. São Paulo: Olivetti do Brasil S.A., 1978b.

ANDUJAR, Claudia. Poesia, pintura e fotografia. Entrevista a Augusto Massi, Eduardo Brandão e Álvaro Machado. In: ANDUJAR, Claudia. A vulnerabilidade do ser. São Paulo: Cosac Naify; Pinacoteca do Estado, 2005, p.102-125. 
ANDUJAR, Claudia. Yanomami: frente ao eterno. Uma vivência entre os índios Yãnomam. São Paulo: Práxis, 1978a.

ANDUJAR, Claudia. LOVE, George. Amazônia. São Paulo: Praxis, 1978.

CABRAL, Sabrina Alvernaz Silva; MEDEIROS, Sérgio Luiz Rodrigues. Andujar e a captura do corpo. Remate de Males, Campinas-SP, v. 40, n. 1, p.147-164, jan./jun. 2020. Disponível em https://periodicos.sbu.unicamp.br/ojs/index.php/remate/article/view/8657704.

Acesso em 20 jun. 2021.

CASTANHEIRA, Rafael. Poéticas de resistência: a representação do Outro nas fotografias de Claudia Andujar e Miguel Rio Branco. Mosaico, Goiânia, v. 9, n. 1, p.125-144, jan./jun. 2016. Disponível em http://seer.pucgoias.edu.br/index.php/mosaico/article/view/4757. Acesso em 17 jun. 2021.

Claudia Andujar: O invisivele Reahu/ The invisible and Reahu [1974-1976]. Documento digital contendo 21 páginas. Acervo Galeria Vermelho.

DUARTE, Rogério. Olhares do infinito - notas sobre a obra de Claudia Andujar. Studium, Campinas, n. 12, p.40-61, 2003. Disponivel em https://econtents.bc.unicamp.br/inpec/index.php/studium/article/view/11747. Acesso em 15 jun. 2021.

GARCEZ, João Pedro. A autora como xamã ou o que deve a arte de Andujar aos Yanomami?. Wamon, Manaus, v. 5, n. 2, p.159-171, 2020. Disponível em https://www.periodicos.ufam.edu.br/index. php/wamon/article/view/8231. Acesso em 20 jun. 2021.

GOW, Peter. Steps towards an ethnographic theory of acculturation. Etnografia. Praktyki, Teorie, Doświadczenia, Gdańsk, v. 1, p.34-39, 2015. Disponível em https://www.ejournals.eu/Etnografia/2015/1-2015/art/8981/. Acesso em 23 ago. 2020. 
GRUPIONI, Luís Donisete Benzi; GRUPIONI, Maria Denise Fajardo. Entrevista com Darcy Ribeiro. Horizontes Antropológicos, Porto Alegre, ano 3, n. 7, p.158-200, nov. 1997. Disponível em https://www. scielo.br/scielo.php?script=sci_arttext\&pid=S0104-71831997000300158\&lng=pt\&tlng=pt. Acesso em 25 ago. 2020.

HATA, Luli. Sonhos xamânicos na arte contemporânea. Artefactum, Rio de Janeiro, ano X, v. 16, n. 1, n.p., 2018. Disponível em http://artefactum.rafrom.com.br/index.php/artefactum/article/ view/1612. Acesso em: 19 jun. 2021.

KOPENAWA, Davi; ALBERT, Bruce. A queda do céu: palavras de um xamã yanomami. Tradução de Beatriz Perrone-Moisés. São Paulo: Companhia das Letras, 2015.

LIMA, Tânia Stolze. O dois e seu múltiplo: reflexões sobre o perspectivismo em uma cosmologia tupi. Mana, Rio de Janeiro, v. 2, n. 2, p.21-47, out. 1996. Disponível em http://www.scielo.br/pdf/ mana/v2n2/v2n2a02.pdf. Acesso em 9 mar. 2021.

MORAES, Ana Carolina Albuquerque de. Claudia Andujar e Marcello Tassara: o transe yanomami na fotografia e no cinema. Artelogie, Paris, n. 12, p.1-17, 2018. Disponível em https://journals.openedition.org/artelogie/2572?lang=pt. Acesso em: 10 jun. 2021.

MORAES, Ana Carolina Albuquerque de. Do converso ao Xamã: Religiosidade Yanomami em Claudia Andujar. In: FREIRE, Luiz; QUIRICO, Tamara; VALLE, Arthur; ANDRADE, Marco Pasqualini de [Orgs.]. Anais do XXXVIII Colóquio do Comitê Brasileiro de História da Arte: Arte e Erotismo - prazer e transgressão na história da arte. Florianópolis: Comitê Brasileiro de História da Arte - CBHA, 2019 [2018], p.233-244. Disponível em http://www.cbha.art.br/coloquios/2018/anais/pdfs/02\%20 Ana\%20Carolina\%20Albuquerque.pdf. Acesso em 10 jun. 2021. 
MORAES, Ana Carolina Albuquerque de. Sonhos xamânicos: diálogos entre Claudia Andujar e Davi Kopenawa. In: BULHÕES, Maria Amélia; FETTER, Bruna; ROSA, Nei Vargas da [Orgs.]. Arte além da arte: Anais do $2^{\circ}$ Simpósio Internacional de Relações Sistêmicas da Arte [recurso eletrônico]. Porto Alegre: Universidade Federal do Rio Grande do Sul, 2020, p.131-140. Disponível em https://2simposioirsablog.wordpress.com. Acesso em 10 jun. 2021.

NOGUEIRA, Thyago. Claudia Andujar: a luta yanomami. In: NOGUEIRA, Thyago [Org.]. Claudia Andujar: a luta yanomami. São Paulo: IMS, 2018, p.161-248.

RAMALHO, Moisés. Os Yanomami e a morte. 2008.163 p. Tese [Doutorado em Antropologia Social]. Faculdade de Filosofia, Letra e Ciências Humanas, Universidade de São Paulo. São Paulo.

TAYLOR, Kenneth I. A Geografia dos Espíritos: o xamanismo entre os Yanomami setentrionais. In: LANGDON, E. Jean Matteson [Org.]. Xamanismo no Brasil: novas perspectivas. Florianópolis: Editora da UFSC, 1996, p. 117-151.

VIVEIROS DE CASTRO, Eduardo. A floresta de cristal: notas sobre a ontologia dos espíritos amazônicos. Cadernos de campo, São Paulo, n. 14/15, p.319-338, 2006. Disponível em http://www.revistas.usp.br/cadernosdecampo/article/view/50120/55708. Acesso em 4 jul. 2018.

VIVEIROS DE CASTRO, Eduardo. A inconstância da alma selvagem e outros ensaios de antropologia. São Paulo: Cosac Naify, 2002.

VIVEIROS DE CASTRO, Eduardo. Os pronomes cosmológicos e o perspectivismo ameríndio. Mana, Rio de Janeiro, v. 2, n. 2, p.115-144, out. 1996. Disponível em http://www.scielo.br/pdf/mana/v2n2/ v2n2a05.pdf. Acesso em 9 mar. 2021. 


\section{CONSIDERACIONES SOBRE LO SUBLIME Y LA POÉTICA DEL MOVIMIENTO}

Considerações sobre o sublime e a poética do movimento

Considerations on the sublime and the poetics of movement

> Mariela Brazón Hernández [Universidade Federal da Bahia, Brasil]*

RESUMEN La finalidad de este artículo es examinar puntos de contacto del arte cinético con la poética de lo sublime, a la vez que se exploran diálogos con otras categorías estéticas y relaciones con expresiones artísticas en las que lo sublime es tratado manifiestamente. Para el desarrollo de las ideas fueron referencia los análisis de Julian Bell, Barnett Neuman y Robert Rosemblum. En lo que respecta al arte del movimiento, se partió de la revisión histórico-crítica de Frank Popper, destacándose sus colocaciones sobre la estética de lo sublime. Fueron identificadas por lo menos tres vías de aproximación al problema: las relaciones con la naturaleza, la inmersión en la luz y el color, y el espíritu de sacralidad inherente a los actos de creación y revelación.

PALABRAS CLAVE Sublime, Arte cinético, Arte del movimiento

Mariela Brazón Hernández é doutora em Artes Visuais pela UFRJ e professora da Universidade Federal da Bahia.

E-mail: marielabrazon@yahoo.com.br. Orcid: https:// orcid.org/0000-0003-4489-4096 
HERNÁNDEZ,

Mariela Brazón.

Consideraciones sobre lo sublime y la poética del movimiento. Revista Poiésis, Niterói, v.

23, n. 39, p. $253-$

277, jan./jun. 2022.

[DOI: https://doi. org/10.22409/poiesis.v23i39.49156]

Este documento é distribuído nos termos da licença Creative Commons

Atribuição -Não Co mercial 4.0 Interna cional (CC-BY-NC) (C) 2022 Mariela Brazón Hernández.

Submetido:

12/3/2021; Aceito:

$25 / 5 / 2021$
RESUMO O objetivo deste artigo é examinar os pontos de contato entre a arte cinética e a poética do sublime, explorando diálogos com outras categorias estéticas e relações com expressões artísticas em que o sublime é manifestamente tratado. Para o desenvolvimento das ideias, usamos como referências as análises de Julian Bell, Barnett Neuman e Robert Rosemblum. No que diz respeito à arte do movimento, o ponto de partida foi a revisão histórico-crítica de Frank Popper, com destaque para suas colocações sobre a estética do sublime. Foram identificadas pelo menos três abordagens para o problema: as relações com a natureza, a imersão na luz e na cor, e o espírito de sacralidade presente em momentos de criação e revelação.

PALAVRAS-CHAVE Sublime, Arte cinética, Arte do movimento

ABSTRACT The purpose of this article is to examine the points of contact between kinetic art and the poetics of the sublime, while exploring dialogues with other aesthetic categories and relationships with artistic manifestations in which the sublime is clearly treated. For the development of the ideas, we used as references the analyses of Julian Bell, Barnett Neuman and Robert Rosemblum. In regard to the art of movement, the starting point was the critical-historical revision of Frank Popper, with emphasis in his work on the aesthetics of the sublime. At least three approaches to the problem were identified: the relationships with nature, the immersion in light and color, and the spirit of sacredness present in moments of creation and revelation. KEYWORDS Sublime, Kinetic art, Art of movement. 
La investigación del movimiento es una de las indagaciones más antiguas del ser humano. Ha sido objeto de atención en las artes, desde sus primeras manifestaciones hasta las más actuales. Creaciones centradas en la poética del movimiento, o que la adoptan en alguna medida, dialogan con la fenomenología de la percepción, el conocimiento científico y tecnológico y la integración del público con la obra, entre otros. Unas veces de manera consciente e intencional, otras, de forma circunstancial, los artistas han incorporado el movimiento como elemento fundamental de sus trabajos, dando lugar a un espectro amplio de investigaciones sobre sus aspectos físicos, materiales, técnicos y conceptuales, bien como sobre sus dimensiones formales, expresivas y simbólicas, además de los vínculos con las esferas estética, psicológica, filosófica y espiritual.

En el arte cinético la reflexión sobre el movimiento [su naturaleza, conceptuación, percepción, fenomenología] es el eje principal alrededor del cual se conciben y desarrollan las obras. Trabajar el movimiento, no como representación sino como manifestación, fue el principal desafío de los cinéticos y de los artistas que posteriormente incorporaron el fenómeno como componente importante de sus investigaciones. Aquí recurro a las expresiones "arte del movimiento" y "poética del movimiento" para abarcar tanto la obra de los exponentes históricos del arte cinético, como las lecturas, apropiaciones y ampliaciones hechas hasta la actualidad.

En este estudio el foco se dirige a los puntos de contacto de la investigación cinética y la categoría de lo Sublime, así como a su interacción con otras categorías estéticas [POPPER, 1968, p. 224-243]. Desde la aparición del término, en el tratado del Pseudo-Longino [s. I], el concepto de lo sublime ha pasado por diversas formulaciones. En ese devenir, importantes puntos de inflexión han sido las ideas presentadas por Edmund Burke en Una investigación filosófica sobre el origen de nuestras ideas de lo sublime y lo bello [1757]; Immanuel Kant en la Crítica del Juicio [1790]; Friedrich Schiller en De lo sublime [1793]; Arthur Schopenhauer en El mundo como voluntad y representación [1819]; Friedrich Hegel en sus Lecciones sobre filosofía de la religión [1827]; Barnett Newman en Lo sublime es ahora [1948] y Jean-François Lyotard en Lecciones sobre la analítica de lo sublime [1991] [BELL, 2013] [MORLEY, 2010]. Las teorías propuestas por estos autores exponen una amplia gama de emociones vinculadas a lo sublime, muchas veces simultaneas y contradictorias, como asombro, miedo, atracción, reverencia, estupefacción, sobrecogimiento, deslumbramiento, etc.; asociadas a hechos que nos resultan inexplicables, intangibles, inexpresables, 
irrepresentables, inalcanzables, trascendentales, imposibles de comprender y enunciar racionalmente, como lo inmensamente poderoso, lo infinito -ínfimo o supremo-, lo inmaterial, el vacio, lo sagrado, lo incorpóreo y lo abismal, entre otros.

El arte cinético fue expuesto por primera vez en 1955 [Le Mouvement, Galería Denise René, París], algunos años después de que Barnett Newman publicara su ensayo The sublime is now, en el que discute el tratamiento de lo sublime en el expresionismo abstracto, y antes de que Robert Rosenblum usara el término "Abstract sublime" [1961] para constatar la prolongación del sublime romántico en exponentes de dicho movimiento. Aun cuando los cinéticos no demostraron interés explícito por la categoría de lo sublime, varios aspectos de la misma, destacados por Rosenblum en obras expresionistas abstractas, también pueden ser identificados en obras cinéticas; entre ellos: la activación del vacío, el uso de recursos simples para obtener efectos impactantes, la supresión de la forma para transmitir la sensación de infinitud y la evocación de una dimensión cósmica.

El movimiento, trabajado desde la dimensión artística, es fuente de ricas experiencias estéticas y de intensas vivencias personales. Fenómenos que son incontrolables e imposibles de presentar pueden desencadenar el sentimiento de lo sublime. Remiten a aquello cuyo poder nos sobrepasa, que está más allá de los límites de nuestra comprensión, y que, aun cuando es inquietante, sobrecogedor u ofuscante, nos cautiva y seduce, desafiando nuestras capacidades de expresión y representación. Temblores violentos, desplazamientos sutiles, vibraciones intangibles, radiaciones, pulsaciones, oscilaciones, repeticiones, flujos, todos ellos son materia prima de lo sublime en la poética del movimiento.

\section{Es probable que varios artistas aquí citados no} hayan tenido conciencia de en qué medida ni en qué sentido sus obras podrían estar relacionadas con lo sublime. El estudio de su producción y de eventuales posicionamientos teóricos sobre el diálogo de lo cinético con lo sublime, revela cruces de esta categoría con otras, como lo asombroso, lo lúdico, lo trascendental y lo inefable. Lo sublime, tratado desde la poética del movimiento, también puede estar asociado a la vitalidad y sacralidad de la Naturaleza.

En la manera como el arte del movimiento trabaja con lo sublime hay aspectos que se repiten y soluciones que se destacan. Llevando esto en consideración, me he detenido en obras específicas, exponiendo reflexiones sobre objetos concretos, para que las ideas discutidas puedan ser mejor visualizadas y comprendidas. Sin embargo, es importante recordar que la diversidad de procedimientos en el arte cinético no permite establecer generalizaciones o categorizaciones. 
Alimentado por los ríos más desconocidos del continente, el Caroní es un crisol de tumultos. En él caen los Grandes Juegos de Agua de América, llevados a la escala de América, con bocas de cavernas que vomitan cascadas enormes [...] No puede concebirse nada más impresionante que el salto de Tobarima, dado por el Caroní en medio de la selva más cerrada y feroz, para meterse en gargantas donde apenas puede creerse que quepan tantas y tantas aguas. Y es que el Caroní es río estruendoso, río que brama en sus cañones, que retumban en trueno al pie de sus raudales...

[CARPENTIER, 1999, p. 28-29]

Localizada en la región de la Guayana venezolana, la Central Hidroeléctrica Simón Bolívar [también conocida como Hidroeléctrica del Guri] es alimentada por el río que tanto impactó a Alejo Carpentier: el Caroní. Principal planta de generación eléctrica del país, su construcción [1963-1986] marcó uno de los períodos más importantes del desarrollo económico de Venezuela. Es una obra de ingeniería grandiosa, que cumplió con éxito uno de los objetivos trazados por los sucesivos gobiernos que participaron en su construcción: proyectar la imagen de un país moderno, con una economía pujante y capaz de ejecutar grandes emprendimientos para explotar las ilimitadas riquezas naturales.
Solar [1985], de Alejandro Otero [Venezuela, 1921-1990]; la Plaza del Soly la Luna [1986], de las arquitectas venezolanas Esther Áñez y Lissette Ávila; y las Ambientaciones Cromáticas de las dos salas de máquinas [1986], de Carlos Cruz-Diez [Venezuela, 1923-2019].

La obra de Otero [figuras 1 y 2], de dimensiones monumentales, es visible a gran distancia, como incrustada en un paisaje que el hombre intenta dominar sin lograrlo por entero. Comparada con la represa, la Torre Solares un pequeño gigante que se levanta decidido, muy cerca del torrente liberado por las compuertas. Su presencia transmite una mezcla de miedo y encanto que hace evidente nuestra insignificancia ante las fuerzas primarias de la naturaleza. 


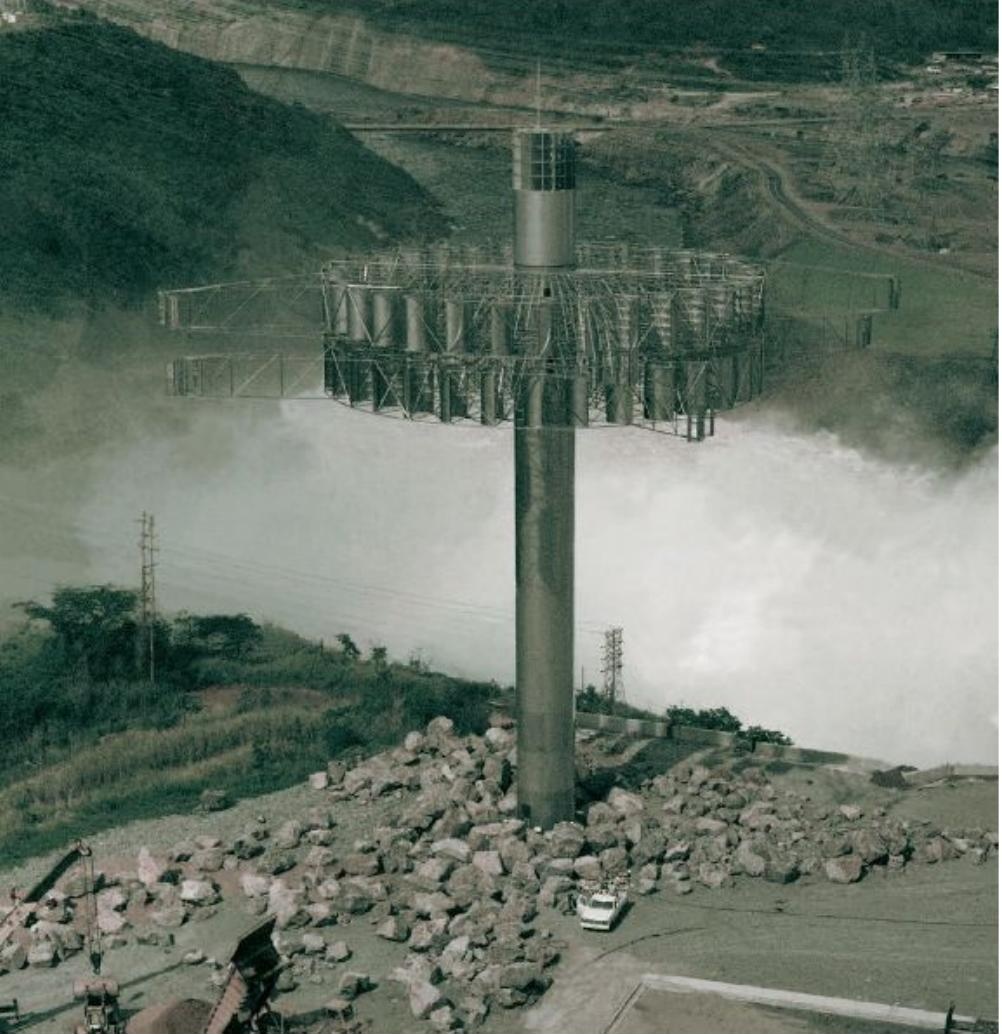

Fig. 1 Alejandro Otero, Torre solar, 1985.

[Fuente: RAMOS, María Helena. Alejandro Otero: Drawings for Sculptures. S.I.: Otero Pardo Foundation, 2019].

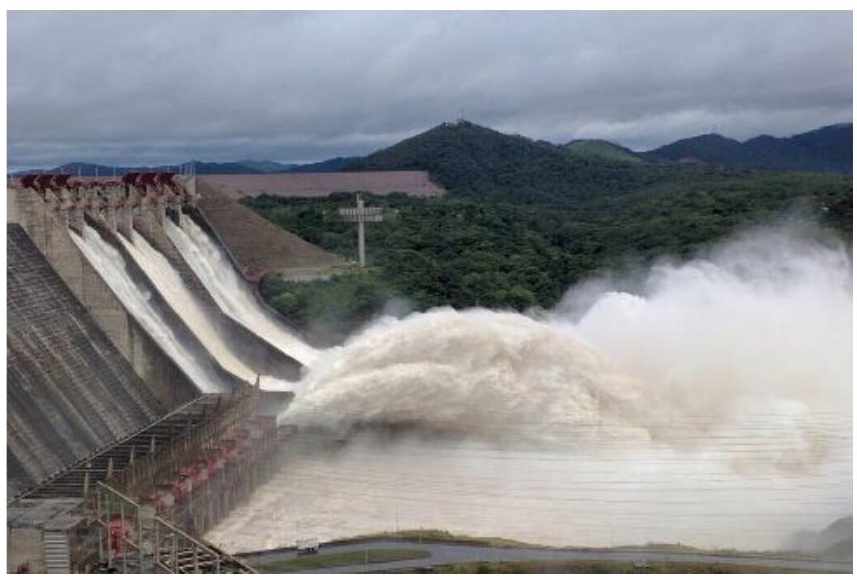

Lo monumental por sí solo no despierta el sentimiento de lo sublime. Como explica Lyotard [1993, p.107], "Não é o pensamento da 'grande unidade', mas o da progressão em direção ao 'cada vez maior' que se experimenta como sublime". La Torre Solar actúa como uno de los peldaños de esa progresión, que parte de nosotros, ínfimos seres humanos, pasa por la escultura monumental, la cual, movida por el viento, encara el paredón de concreto - punto de tensión entre el hombre y la naturaleza-, que con su presencia colosal refrena el imponente río. La energía que recorre esa secuencia ascendente se manifiesta con plenitud cuando se abren las compuertas de la represa. El entrelazamiento de hombre, arte, tecnología y naturaleza es orquestado con vivacidad por el agua y el viento, y la Torre Solares un eslabón activo de esa integración. De esta manera, nos sentimos parte de una realidad que nos sobrepasa y nos perturba. Estamos frente a un sublime impetuoso, cuyo vigor se manifiesta tanto en el estruendo de las aguas como en el giro de los metales. El sonido, de una intensidad sobrecogedora, es componente fundamental de lo sublime.

Fig. 2 Presa y compuertas de la Central Hidroeléctrica Simón Bolívar, con la Torre Solar al fondo.

[Fuente: https://stl.uvnimg.com/a5/d0/f727788f40e48a34e7699329013c/captura-de-pantalla-2017-08-15-alas- $1.20 .00 \% 20$ PM.png]

HERNÁNDEZ, Mariela Brazón. Consideraciones sobre lo sublime y la poética del movimiento. 


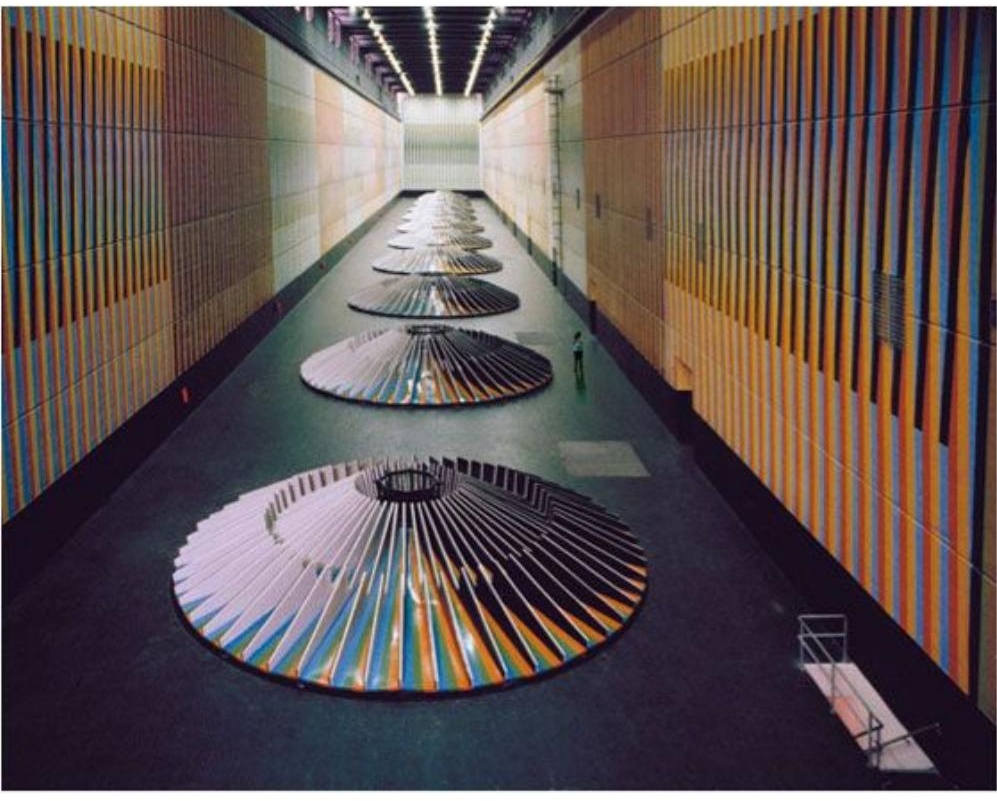

Fig. 3. Carlos Cruz-Diez, Ambientación Cromática, Sala de turbinas n. 1, Central Hidroeléctrica Simón Bolívar, Venezuela, 1977- 1986. [Fuente: http://www.cruz-diez.com/work/architectural-integrations/1970-1979/ambientacion-cromatica_3/]

En la Torre Solar, como en otras obras eólicas de Otero, el viento revela la condición activa de lo real. Circula por entre obstáculos al tiempo que los impulsa. Hace perceptible las relaciones entre espacio y movimiento, en algunos casos con fluidez y en otros con precipitación, dependiendo de las condiciones climáticas y del ímpetu del río. No por casualidad el formato escogido por el artista
Fig. 4. Carlos Cruz-Diez, Ambientación Cromática, Sala de turbinas n. 1, Central Hidroeléctrica Simón Bolívar, Venezuela, 1977-1986. [Fuente: SALOMÓN, Luisa. Guri. Serie Las Horas Oscuras. Prodavinci, 2020].

es el de un ensamble de veletas que, visto desde la perspectiva de un observador humano, parece un enorme árbol metálico cuya copa se extiende horizontalmente, dejando entrever el cielo y la espuma. Un árbol que no protege, dejando expuesta nuestra pequeñez y vulnerabilidad.

En 1986 Carlos Cruz-Diez concluye las Ambientaciones Cromáticas que ocupan las dos salas de Revista Poiésis, Niterói, v. 23, n. 39, p. 253-277, jan./jun. 2022. [DOl: https://doi.org/10.22409/poiesis.v23i39.49156] 

3 y 4]. Estructuras vibrantes se extienden por enormes paredes y por las superficies de los generadores, cuyos mecanismos internos efectúan la extraordinaria conversión de energía que da sentido al complejo industrial. Es el corazón del Guri. La escala usada por Cruz-Diez traspone a estos espacios Las vibraciones cromáticas operan como prolongaciones de los movimientos subterráneos a los que no tenemos acceso.

En conversaciones con el crítico de arte Ariel Jiménez, respecto a la experiencia suscitada por las ambientaciones cromáticas del Guri y a nuestra interacción con las estructuras hidráulicas y las fuerzas de la naturaleza, Cruz-Diez afirma: turbinas de la misma central hidroeléctrica [figuras cerrados la relación del hombre con la naturaleza.

\section{TRANSITAR EL COLOR}

I feel myself colored by all the nuances of infinity Paul Cézanne [apud DORAN, 2001, p. 114]

\section{Las Fisicromías de Cruz-Diez son ensambles de} piezas cuyos colores interactúan ópticamente, generando nuevas tonalidades en el espacio, sin necesidad de un soporte físico. Algunas de ellas siguen un formato curvo que invita a la inclusión y que, debido a su extensión, parece abrazar e incorporar el espectador. Para apreciar el efecto de movimiento virtual, el observador se distancia de las Fisicromías y se desplaza ante ellas, siendo así capturado por un campo de modulaciones cromáticas. Como no hay puntos estables para su mirada, gana consciencia de que no existe una visión privilegiada. Es una experiencia en la que sujeto y objeto existen en total

Cuando entras allí, tienes una extraña sensación de asombro, admiración y belleza, muy alejada de los sentimientos de la vida cotidiana. [...] Es sublime, precisamente, porque cuando te enfrentas a un espacio de dimensiones tan extraordinarias, solo puedes sentir asombro por el hecho de que el ser humano haya sido capaz de hacer algo semejante. Al mismo tiempo, al mirar directamente al gran muro de concreto, desde una pequeña plataforma que permite ver de cerca la apertura de las compuertas, realmente se siente una mezcla de terror y admiración. No somos nada ante esa bruma que genera un arco iris y, de hecho, sentimos terror y asombro. Es una experiencia que nunca se olvida. [JIMENEZ, 2014, p. 216, traducción nuestra] completa cuando, asociación.

La inclusión del espectador se hace aún más éste, además de sentirse "dentro del color", puede "recorrerlo". Es el caso de las Cámaras de Cromosaturación, obras que sintetizan en muchos aspectos las investigaciones artísticas de Cruz-Diez [fig. 5]. Constituidas por ambientes 
que se conectan, cada uno bañado por entero de luz colorida, las situaciones en ellas generadas inducen alteraciones en la visión que resultan inexplicables. La exposición prolongada a un determinado color satura el ojo y lo cansa, hasta que no puede responder más al estímulo. Por este motivo, quien se detiene en cualquiera de las salas sentirá después de unos pocos minutos su visión completamente

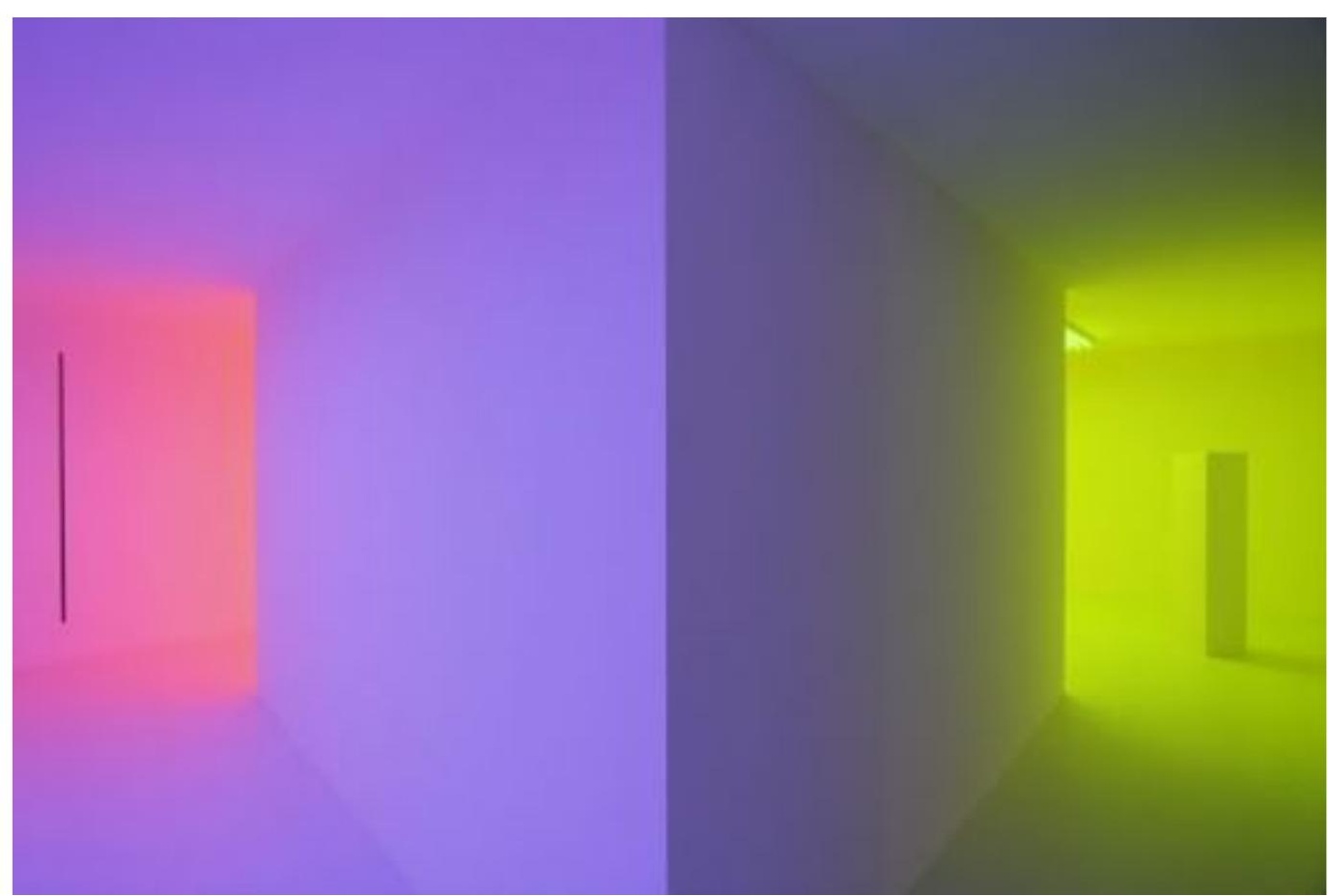

Fig. 5. Carlos Cruz-Diez, Cromosaturación, Exposición "Carlos Cruz-Diez. Color in Space and Time", 2010-2011. [Fuente: http://www.cruz-diez.com/work/chromosaturation/2010-to-date/chromosaturation-at-the-carlos-cruzdiez-color-in-space-and-time-exhibition/] saturada, pasando, en un instante, a ver el ambiente totalmente blanco. Esa es una de las sensaciones más impactantes y desconcertantes que el público de una cámara de cromosaturación puede experimentar. Sin embargo, debemos decir, es raro que las personas permanezcan por mucho tiempo en una sala. La estructuración de las cámaras de cromosaturación induce más a un recorrido sin demoras que a la exploración detenida de cada ambiente. Lo más común es que el espectador circule, fascinado por la continuidad del color, experimentando sus transiciones y modificaciones. De esa manera, los cambios en la percepción son fluidos, así como son difíciles de localizar las zonas donde un color se encuentra con otro. Estas características se repiten en la Cromosaturación del Museum of Fine Arts de Houston, inaugurada en noviembre de 2020 [fig. 6] en un pasaje que comunica dos sectores del museo. 
En las cromosaturaciones lo sublime responde a varios factores: I dificultad para identificar fronteras [entre los colores, entre la luz y el color, y entre nuestro cuerpo y el ambiente], la imposibilidad de explicar con la razón cómo sucede la transformación del color-y hasta su desaparición-y el desconcierto causado por la presencia absoluta del color en el espacio, sin ningún tipo de soporte material. En síntesis: la incapacidad de comprender de manera racional un fenómeno en el que estamos totalmente inmersos.

Transitar es una manera de hacerse parte de un ambiente, con toda la inquietud que eso pueda provocar. Muchas veces la experiencia del pasaje

Figura 6. Carlos Cruz-Diez, Cromosaturación light tunnel, Museum of Fine Arts Houston, 1965-2017.

[Fuente: https://www.sicardi.com/news/antonio-asis-geraldo-de-barros-martha-boto-carlos-cruz-diez-gustavo-diaz-magdalena-fernandez-leon-ferrari-gego-oscar-munoz-alejandro-otero-julio-le-parc-miguel-angel-rojas-fanny-sanin-jesus-rafael-soto-luis-tomasello-francisco-sobrino-joaquin-torres-garcia-and-gregorio-vardanega-among-others2] está vinculada a un acto de iniciación; más aún cuando el espacio recorrido remite a tantas incertezas. La revelación que Olafur Eliasson [Dinamarca/Islandia, 1967] propicia en Din blinde passager [2010] es la conciencia del medio en que existimos [fig. 7]. Con recursos comparables a los de las cámaras de cromosaturación, Eliasson induce el fruidor a una experiencia vaga y nebulosa. Mientras las indefiniciones en las cámaras de cromosaturación son básicamente fenomenológicas, en las obras de Eliasson Ilegan a ser éticas, pues activan juicios sobre nuestro papel en un mundo que se autodestruye. 


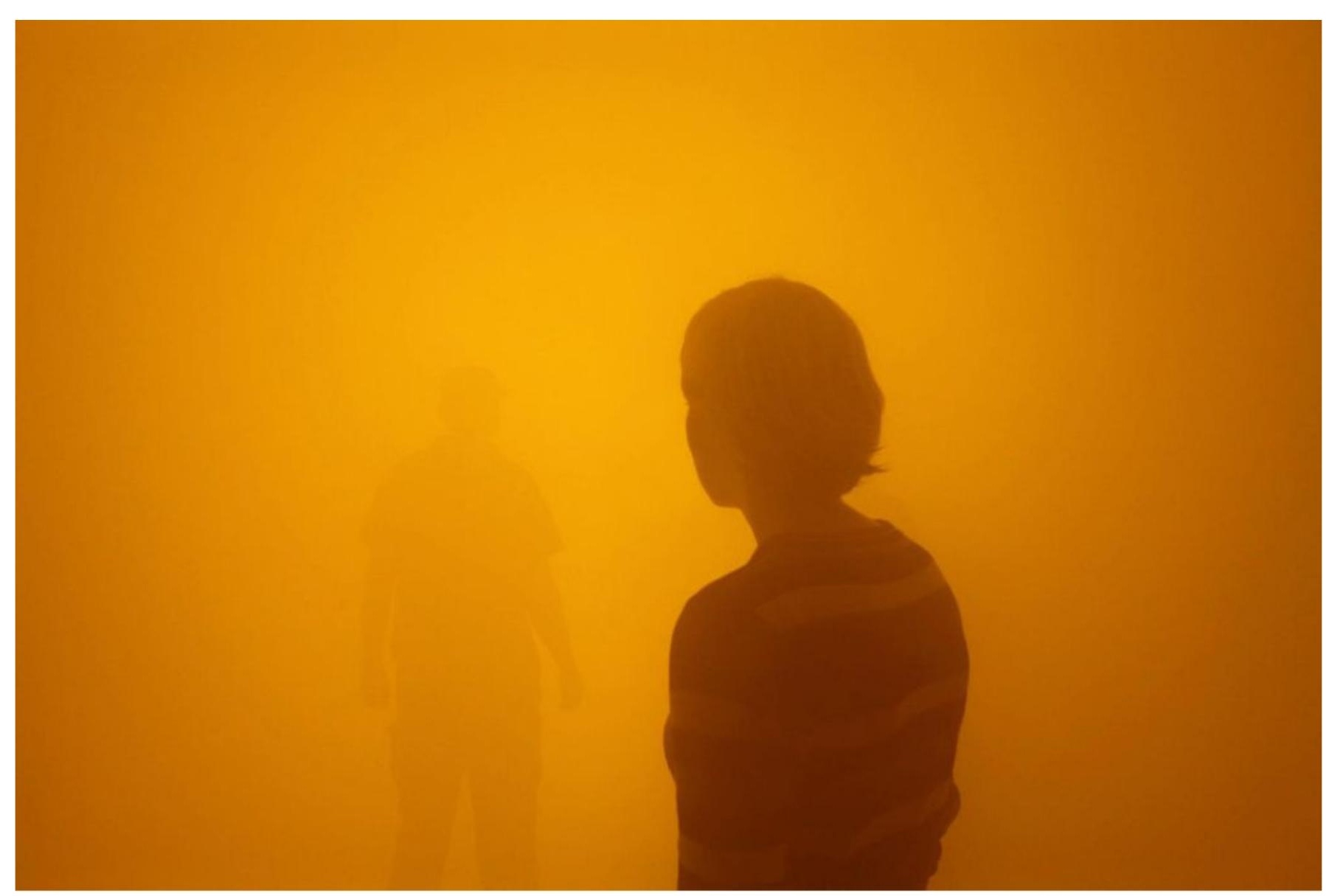

Fig. 7- Olafur Eliasson, Din blinde passager, 2010

[Fuente: https://olafureliasson.net/archive/artwork/WEK 100196/din-blinde-passager]

Las atmósferas de las cromosaturaciones, con sus referencias a la inmaterialidad, lo transitorio y lo indeterminado, son lugares para lo trascendental. Más que una experiencia fenomenológica, la inmersión cromática, que en Cruz-Diez llega a ser un acto de identificación con el color, puede trasladarnos al lugar de un absoluto. Se crean así atmósferas similares a las religiosas y vínculos con la luz sagrada. Algo que también James Turrell [USA, 1943] alcanza en sus instalaciones [fig. 8] "Turrell creates a similar 
experience of "Ganzfeld": a German word to describe the phenomenon of the total loss of depth perception as in the experience of a white-out." [GANZFELDS, 2021, n.p] La toma de conciencia de cuan inaprensible es el medio en que nos encontramos tiene carácter de revelación. Cuando el color "desaparece" en la visión saturada, todo "se hace" luz. No es una experiencia de ausencia y sí de plenitud, de comunión, como lo son las epifanías.

\section{HECHO DE LUZ}

... debemos 'pintar' con luz, fluctuante, oscilante y prismática, en lugar de pigmentos. Esto nos permitirá encarar mejor la nueva concepción del espacio-tiempo.

László Moholy-Nagy [1972, p.71]

Sin renunciar a la geometría formal, el arte del movimiento busca despertar la conciencia de una realidad espacio-temporal que impacta con la fuerza de



Fig. 8- James Turrel, Breathing light, 2013

[Fuente: https://jamesturrell.com/work/breathing-light/]

Fig. 9 [página seginte]- Julio Le Parc, Continuel-lumière mobile, 1960.

[Fuente: https://www.daros-latinamerica.net/artwork/continuel-lumi\%C3\%A8re-\%E2\%80\%93-mobile] una revelación. La

luz, entidad básica

de la naturaleza, es trabajada como estado energético, intangible. Su velocidad, como explicado por la ciencia-campo de conocimiento valorizado por los cinéticos-, no puede ser ultrapasada por la de ningún cuerpo, lo que la hace una constante absoluta y universal a la que no podemos acceder empíricamente ni abrazar racionalmente.

HERNÁNDEZ, Mariela Brazón. Consideraciones sobre lo sublime y la poética del movimiento. 


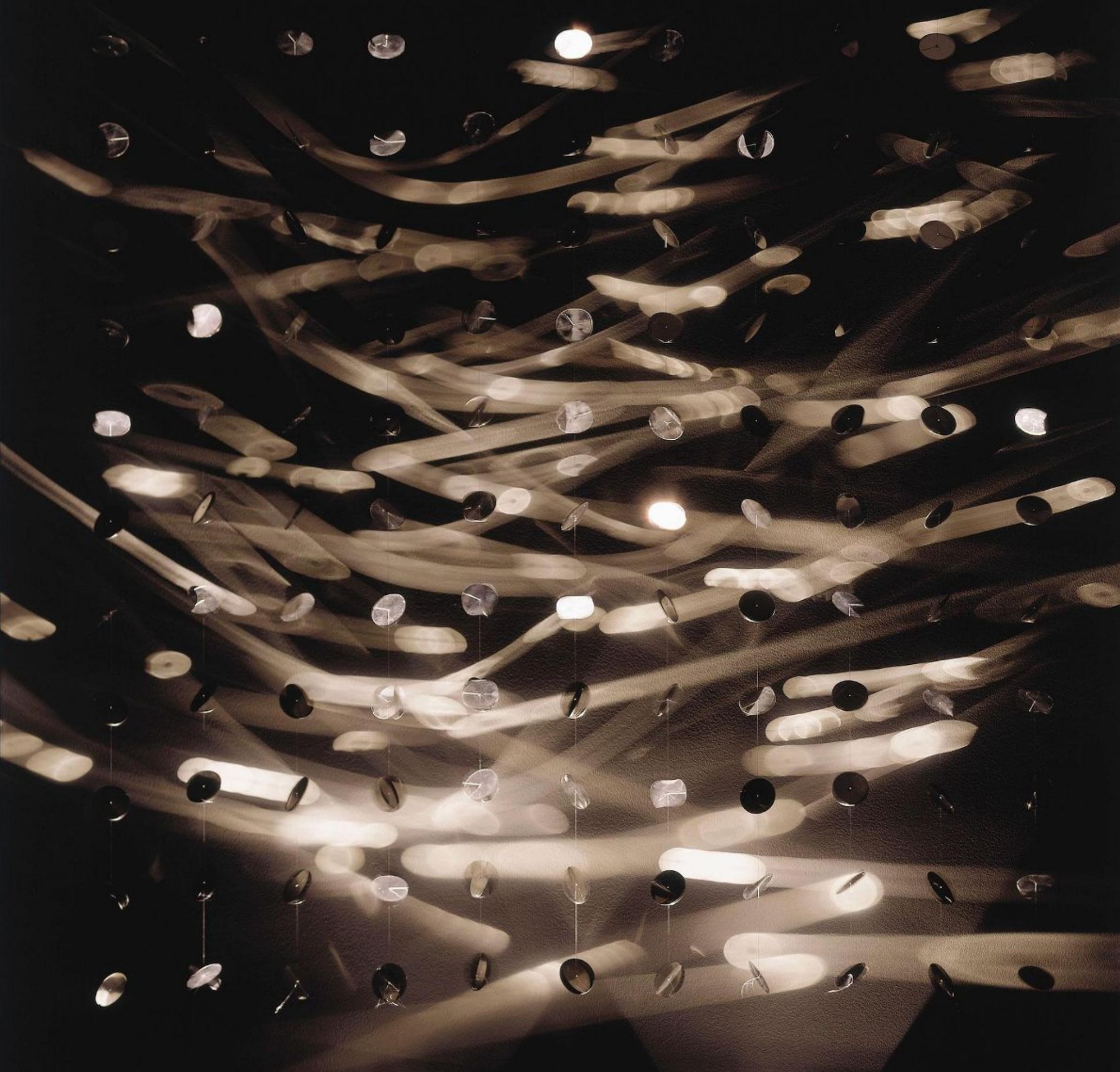


La presencia de la luz es muy poderosa en el arte cinético. En la serie Continuel-lumière mobile [fig. 9] de Julio Le Parc [Argentina, 1928], efectos sensoriales generados por luces que se reflejan y multiplican en incontables superficies pulidas crean ambientes cuyas formas y límites son imprecisos, difíciles de determinar, produciéndose así la sensación de que el espacio es enteramente ocupado por luz. Lo inmaterial se manifiesta, dejándonos primero estupefactos y en seguida maravillados.

La experiencia estética asociada a estas obras está intrínsecamente ligada a la manera como son presentadas: generalmente en espacios absolutamente oscuros, cerrados y de grandes dimensiones, dentro de los cuales impactan las señales luminosas que recorren el vacío tridimensional. El dinamismo que invade la atmósfera de los móviles de Le Parc es pleno, pero aún así fugaz e inaccesible. Un sentimiento de inestabilidad y transitoriedad se hace presente. La atmósfera es hipnótica y la experiencia vivida evoca una dimensión que bien podría ser llamada de "cósmica".

Además de Le Parc, otros artistas del movimiento, como Nicolas Schöffer [Hungría, 1912-1992] y Otto Piene [Alemania, 1928-2014], exploraron los efectos de la inmersión de la luz en el espacio, siguiendo el camino iniciado por László Moholy-Nagy [Hungría, 1895-1946] en el Light-Space Modulator. Sin embargo, a diferencia de los anteriores, Le Parc llegó muy cerca de alcanzar una realidad fuera de nuestra comprensión, “...something that presses on us from beyond our normal reality, challenging the assumptions upon which such a reality is based" [MORLEY, 2010, p.18].

Camino parecido al de Le Parc siguió Jesús Soto [Venezuela, 1923-2005] en sus Sólidos Virtuales, fabricados de hilos de nylon muy finos y translúcidos, cuya materialidad, llevada al mínimo, hace de la luz el soporte de la forma. Sin duda se trata de un fenómeno impactante [fig. 10]. Obras como los sólidos virtuales despiertan la conciencia de que hay realidades que no podemos alcanzar porque existen en dimensiones muy diferentes a la nuestra, y cuya naturaleza intangible contrasta con nuestra presencia matérica y corporal. En estas obras la luz es al mismo tiempo materia, forma y contenido.

HERNÁNDEZ, Mariela Brazón. Consideraciones sobre lo sublime y la poética del movimiento. 


\section{GÉNESIS Y REVELACIÓN}

La creación, siempre cargada de revelación, es un lugar perfecto para lo sublime. El movimiento nítido y preciso de la Kinetic Construction [1919-20] de Naum Gabo [Rusia, 1890-1977], así como el gesto decidido de los cortes de Lucio Fontana [Argentina, 1899-1968], son actos que, partiendo de recursos mínimos, generan nuevas y complejas realidades espacio-temporales. Actos como estos nos conectan a algo prístino, algo que se muestra por primera vez. Presenciar el instante en el que, a partir de lo ínfimo, el color y la luz se manifiestan, despierta la conciencia de que somos testigos de una génesis.

En Cruz-Diez lo sublime se vincula a la revelación de lo primordial. En el Amarillo Aditivo [1969], por ejemplo, dos líneas finísimas, una verde y una roja, casi inexistentes, pero nítidamente perceptibles, se cruzan sobre un fondo oscuro, creándose virtualmente un nuevo color. [fig. 11] La precisión limpia

Fig. 10- Jesús Soto, Sphère Concorde, 1996

[Fuente: hitps://proa.org/esp/exhibicion-proa-iesus-rafael-soto--vision-en-movimiento--obras.php] y breve del fenómeno es singular. Como en otras obras del artista, sorprende que algo tan elemental tenga un efecto tan impactante. En este sentido, Amarillo Aditivo es un denominador común de las investigaciones de Cruz-Diez, pues señala el "lugar" que potencialmente contiene a todos los colores y el instante en que uno de ellos nace. 


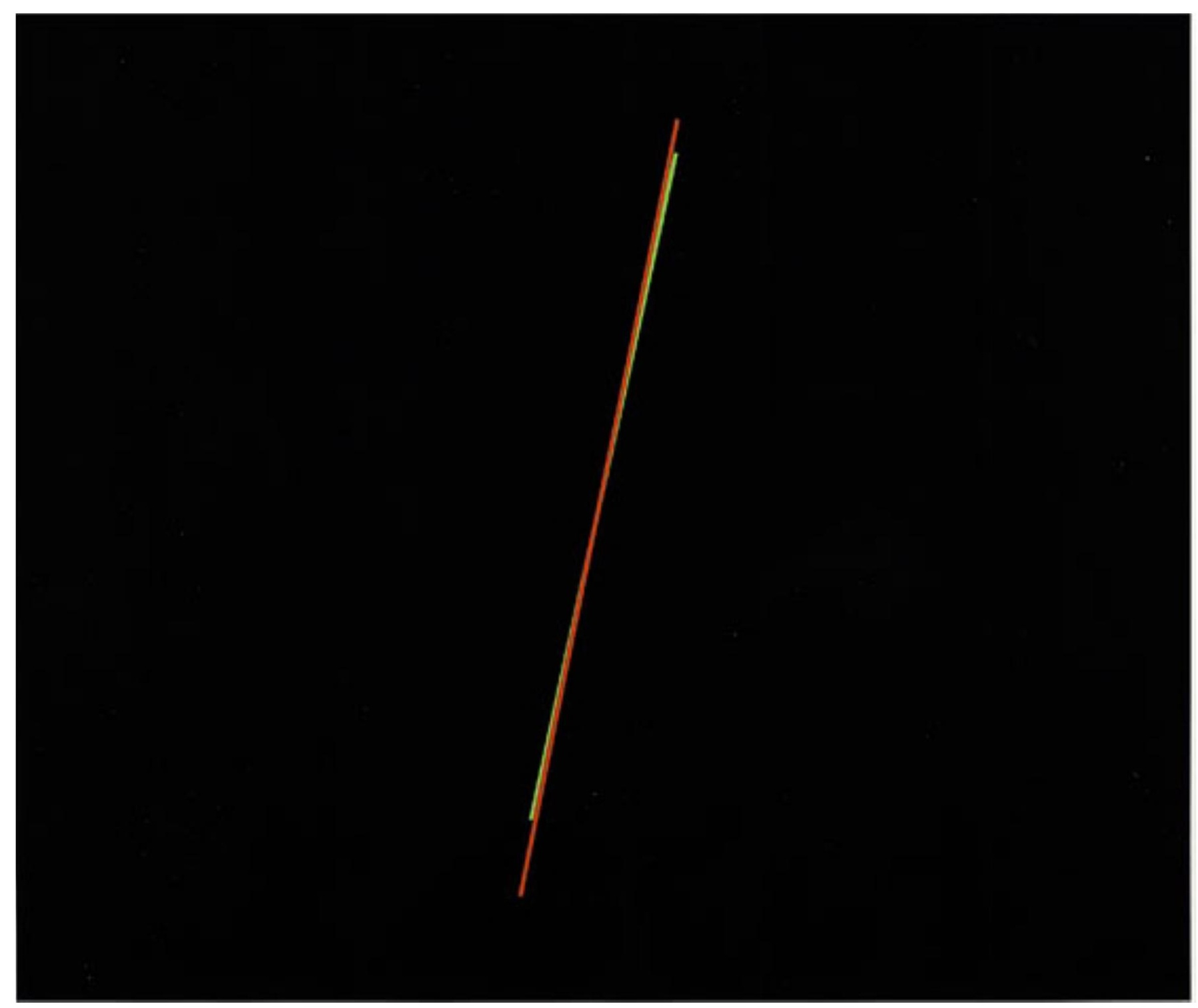

Fig. 11 - Carlos Cruz-Diez, Amarillo aditivo, 1959

PVA sobre papel. $41.9 \times 48.3 \mathrm{~cm}$

Colección Patricia Phelps de Cisneros [Fuente: http://www.cruz-diez.com/work/couleur-additive/1950-1959/amarillo-aditivo/] 
El punto, elemento geométrico adimensional, y que, como tal, está fuera de nuestra comprensión racional y sensorial, es para Almir Mavignier [Brasil, 1925-2018] el "lugar" donde la luz existe potencialmente. Al dotarlo de calidad cromática y textural, Mavignier hace que el punto gane una dimensionalidad que permite tratarlo como fenómeno. Organizado reticularmente, produce mixturas ópticas que generan resplandor. A partir de un núcleo, nacen y se amplifican radiaciones, como si del propio plano naciera luz. [fig. 12]

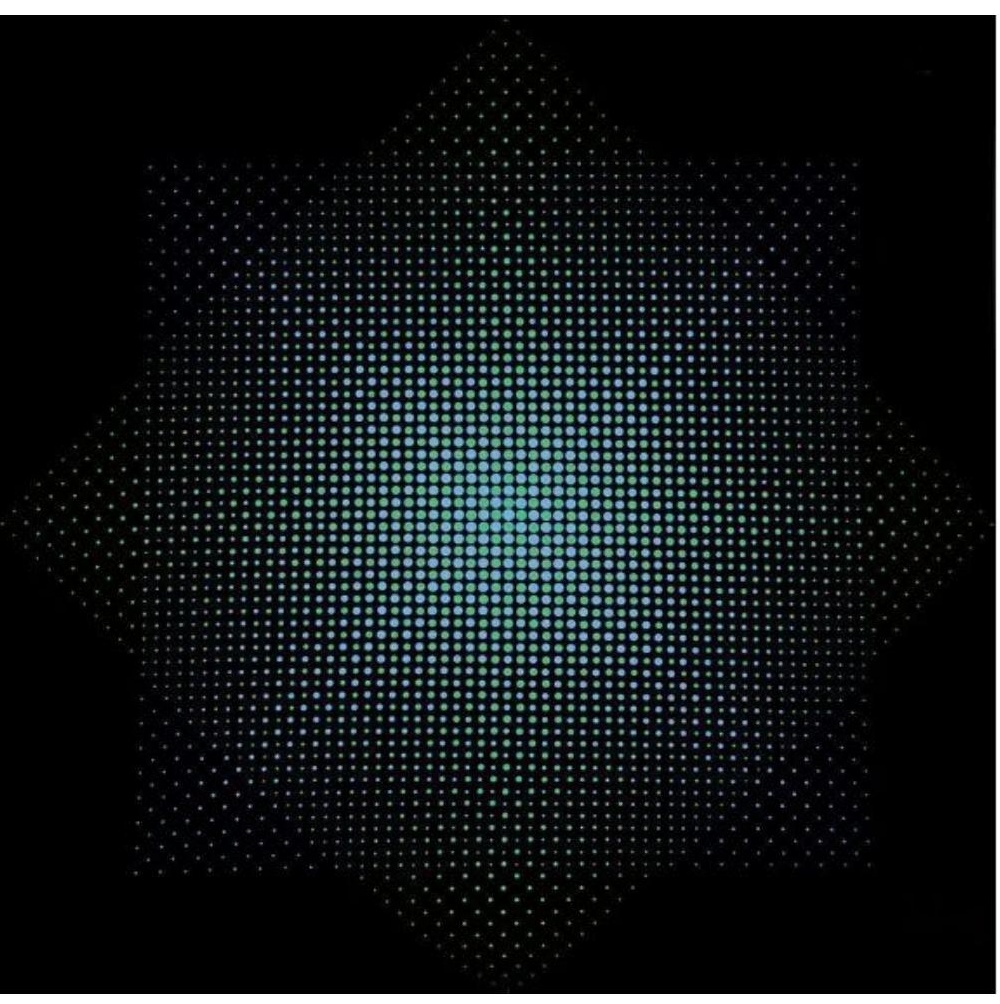

Como explosiones en proceso, liberando energías, las imágenes de Mavignier son eco de las pulsaciones del cosmos. Ellas, como el Amarillo Aditivo, son metáforas del acto mismo de la creación, pues evocan el nacimiento de la entidad más sorprendente y misteriosa de la naturaleza. La que despierta más que cualquier otra la curiosidad científica y la reverencia espiritual: la luz.

Imágenes como esas, que recuerdan estrellas, también fueron trabajadas por Victor Vasarely [Hungría, 1906-1997], quien, siguiendo su interés por la ciencia, trabó en varias de sus obras diálogos con fenómenos y cuerpos astronómicos [fig. 13]. Para llegar al efecto expansivo de estructuras pulsantes, tanto Vasarely como Mavignier estructuraban arreglos de cuadrados anidados, que, partiendo de los más claros hacia los más oscuros, producen la ilusión de diagonales muy brillantes. Este fenómeno es conocido como Chromatic vasarely effect, en homenaje al artista húngaro [TSOFE, 2010, p. 2284]. En ambos casos, las imágenes resultantes recuerdan las reverberaciones del brillo de las estrellas. Se alimenta así nuestra atracción por la intensidad y la inmensidad del cosmos.

Fig. 12- Almir Mavignier, B-8, 1973.

Serigrafia sobre PVC-folie, ejemplar 3/200.

[Fuente: https://www.leilaodearte.com/leilao/2017/marco/33/almir-mavignier-b-8-7915/]

Fig. 13 [página seguinte]- Victor Vasarely, CTA 102, 1965.

[Fuente: https://vasarely.staedelmuseum.de/en/]

Revista Poiésis, Niterói, v. 23, n. 39, p. 253-277, jan./jun. 2022. [DOl: hitps:/,
269 

La imagen de los Cubos virtuales blancos sobre proyección amarilla [1982] de Jesús Soto, está entre las más impresionantes del Teatro Teresa Carreño [Caracas] [fig. 14]. Es una instalación monumental ubicada a más de cuarenta metros de altura, que cubre completamente el techo de concreto del foyer, transformándolo en una enorme masa de vibraciones. Para llegar a la sala de espectáculos, el público sube por una escalera que lo introduce gradualmente a un espacio que sobrecoge por su amplitud. "We cannot encompass it by thinking, and so it remains indiscernible or unnameable, undecidable, indeterminate and unpresentable" [MORLEY, 2010, p. 16]. Desde todos Ios niveles y ángulos, los cubos, casi transparentes, y la cubierta de intenso amarillo, atrapan la mirada. La experiencia en su totalidad es un preámbulo de las emociones que en breve sentirá el espectador, muchas de las cuales permanecerán inenarrables.

Fig. 14- Jesús Soto, Extensión amarilla con cubos virtuales, Foyer del Teatro Teresa Carreño, Caracas, 1983. [Fuente: https://i.pinimg.com/originals/66/c2/89/ 66c289e91 e4cb85959ea217cb5dd6229.jpg]



Revista Poiésis, Niterói, v. 23, n. 39, p. 253-277, jan./jun. 2022. [DOl: https://doi.org/10.22409/poiesis.v23i39.49156] 
cuyas disoluciones cromáticas, en grandes formatos, alcanzaron el estatus de objetos religiosos.

El Penetrable de Houston fue creado específicamente para un ambiente cerrado. Siguiendo el procedimiento de grandes museos de arte, el espacio que ocupa esta obra es grandilocuente y teatral. Desde un nivel elevado puede ser abarcado con la mirada, sobrecogiendo como una aparición. El hecho de ocupar una sala de grandes dimensiones devotada sólo a él, nutre un sentimiento de religiosidad y refuerza su naturaleza sagrada. Es un sagrado que deslumbra por la luz que de él emana. Por la luz que él "es".

A pesar de que hay algo inalcanzable en esta obra, mientras la recorremos nos vamos haciendo parte de ella. No conseguimos tratarla más como algo distanciado. No la comprendemos sin modificarla. La configuración y exposición de obras como este penetrable conducen a un estado que puede ser calificado de trascendental, en el sentido dado por Mukand: "The 'transcendental sublime' will here refer to how looking at a work of art can enable one to be transported, going beyond the given limits to a place of accessing one's spiritual side" [MUKAND, 2015, p.1]

$\star \star \star$
Hemos observado que la poética del movimiento, además de investigar el fenómeno en sí, explora los efectos emocionales que se generan: sublimidad, sorpresa, encantamiento, sacralidad, diversión, libertad, ruptura, vitalidad. El público es movido a pensar no solo sobre su propia percepción, los fenómenos visuales y formales implícitos o la estructuración de los elementos de expresión plástica, sino también, y muy especialmente, sobre como la fruición del movimiento produce emociones y sentimientos complejos.

Obras cinéticas como las aquí presentadas se configuran como auténticas naturalezas. Son campos fenoménicos hacia los cuales nos vemos atraídos, movidos por una mezcla de asombro, encantamiento y perplejidad. Naturalezas en las que el color es espacio, la luz es indicio y el movimiento atributo, y donde ninguna de esas entidades: espacio, color, luz o movimiento, es abarcable con el entendimiento, sea por su dimensión, ubicuidad, indeterminación, fugacidad o por su carácter inasible - cualidades que atraen, a la vez que causan incertezas. Cuando fruimos el arte del movimiento nos hacemos parte de esas naturalezas: dimensiones que estudiamos y comprendemos racionalmente en el ámbito científico, pero que permanecen inaccesibles a nuestros sentidos, tanto en la escala cósmica que nos sobrepasa, como en el ínfimo punto en que nacen la luz y el color. 
Las obras examinadas se conectan con lo sublime mediante lo intangible, inmaterial, infinito e indeterminado; lo que no podemos medir, demarcar o recorrer por entero; lo que nos supera y nos hace conscientes de nuestra finitud y pequeñez en el universo. La poética del movimiento favorece la inmersión en esas dimensiones imprecisas que la razón no puede explicar. Presentar fenómenos que no entendemos ni podemos retener para análisis está en la esencia de lo sublime.

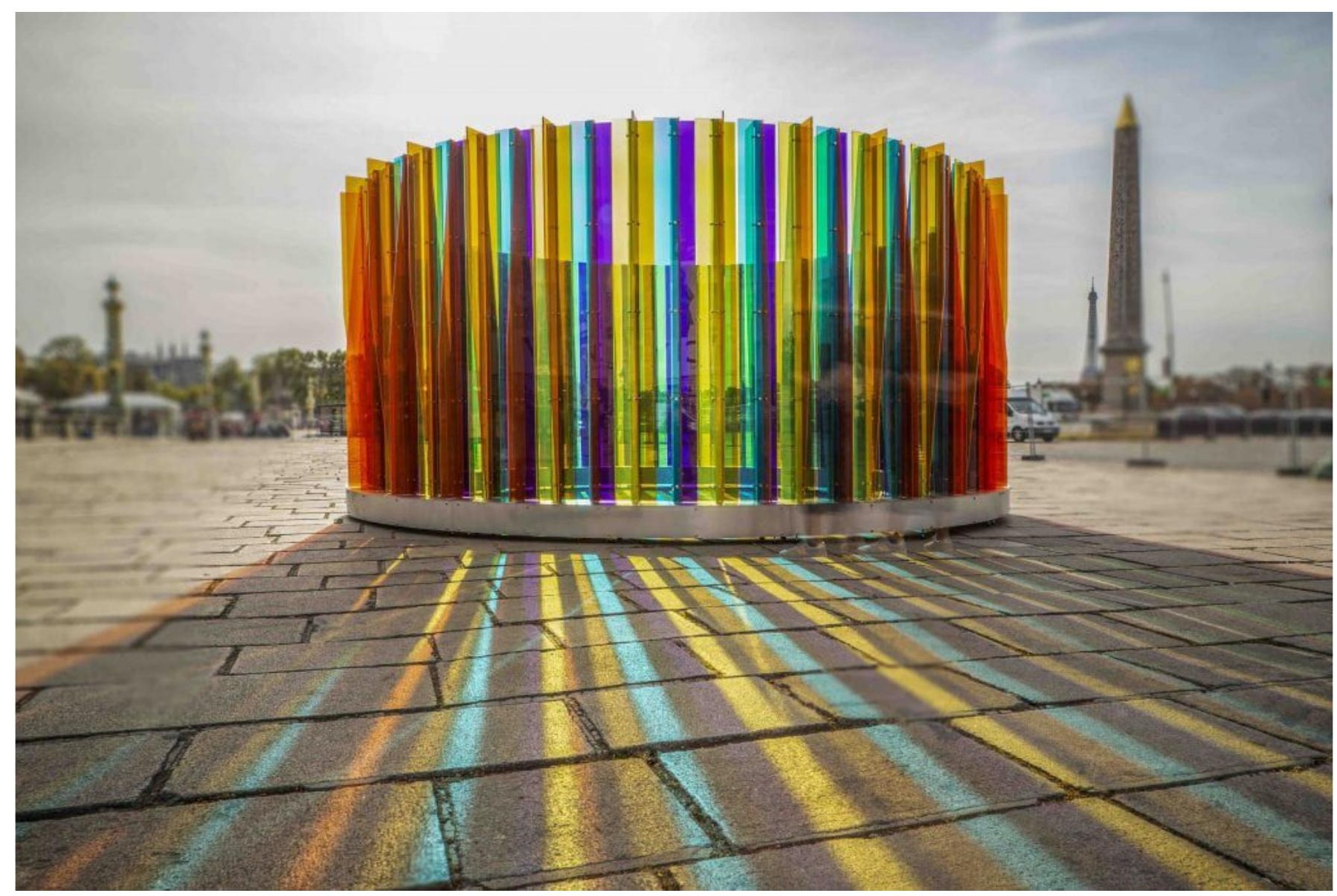

Figura 17- Carlos Cruz-Diez, Enviroment de Transchromie circulaire, 1965-2017.

[Fuente: https://cdn.elnacional.com/wp-content/uploads/2019/10/CHERUBINI3-1024×683.jpg]

HERNÁNDEZ, Mariela Brazón. Consideraciones sobre lo sublime y la poética del movimiento.

$$
274
$$


El sublime cinético poco o nada remite al terror mencionado por Burke. Es un sentimiento permeado de optimismo y entusiasmo. Y ese optimismo resulta, muy probablemente, del fuerte vínculo entre lo cinético y el espíritu moderno, que mucho se manifiesta en la admiración por la ciencia y la tecnología. No sentimos miedo, sino asombro, encantamiento. Lo que reconocemos como primordial, único e irrepetible, nos deja estupefactos y maravillados, por tratarse de algo extraordinario.

A menudo, obras cinéticas "funcionan" gracias a las particularidades -generalmente limitaciones- de la percepción humana, que impiden que ciertas imágenes sean procesadas sin ambigüedad. La sensación de desconcierto está en la imposibilidad de comprender lo que sucede. La duda es racional, pero no así la respuesta.

Reconocer que se está ante algo inexplicable, nos detiene y asombra, pero no necesariamente nos inmoviliza. La exploración sensorial, al no ser enteramente satisfecha, se torna motor de la investigación. [fig. 17] Seducidos por el deslumbramiento y movidos por la curiosidad, nos entregamos a la alegría del descubrimiento. Es en la dimensión lúdica donde nos integramos más fuertemente al objeto cinético y donde se disipa el desconcierto ante lo sublime, transmutándolo en placer. 
BELL, Julian. The contemporary sublime. In: LLEWELLYN, Nigel y RIDING, Christine [eds.]. The Art of the Sublime. London: Tate Research Publication, 2013. Disponible en https://www.tate.org.uk/art/research-publications/the-sublime/the-contemporary-sublime-r1109224. Acceso el 3/5/2020.

CARPENTIER, Alejo. Visión de América. Buenos Aires: Losada, 1999.

DORAN, Michael [ed.]. Conversations avec Cézanne. Berkeley: University of California Press, 2001.

GANZFELDS. James Turrel, 2021. Homepage do artista James Turrel. Disponible en https://jamesturrell. com/work/type/ganzfeld/. Acceso el 10/2/2021.

JIMÉNEZ, Ariel. Carlos Cruz-Diez conversa com Ariel Jiménez. São Paulo: Cosac Naify, 2014.

KANDINSKY, Wassily. De lo espiritual en el arte. Barcelona: Barral Editores, 1978.

LYOTARD, Jean-François. Lições sobre a analítica do sublime. Campinas: Papyrus, 1993.

MOHOLY-NAGY, László. La nueva visión y reseña de un artista. Buenos Aires: Infinito, 1972.

MORLEY, Simon. The contemporary sublime. In: MORLEY, Simon [ed]. The Sublime. Cambridge: The MIT Press. London: Whitechapel Gallery. 2010. p.12-21.

MUKAND, Nandita. The transcendental sublime in contemporary art. Munich: GRIN Verlag, 2015. Disponible en https://www.academia.edu/12045981/The_Transcendental_Sublime_in_Contemporary_Art. Acceso el $21 / 9 / 2020$.

NEWMAN, Barnett. The sublime is now. In: MORLEY, Simon [ed]. The Sublime. Cambridge: The MIT Press. London: Whitechapel Gallery. 2010. pp. 25-27.

POPPER, Frank. Origins and development of kinetic art. London: Studio Vista, 1968.

RAMOS, María Helena. Alejandro Otero: Drawings for Sculptures. S.I.: Otero Pardo Foundation, 2019. 
ROSEMBLUM, Robert. The abstract sublime. ARTnews. Disponible en https://www.artnews.com/art-news/ retrospective/beyond-the-infinite-robert-rosenblum-on-sublime-contemporary-art-in-1961-3811/. Acceso el 19/1/2021. [Originalmente publicado en Art News. [S.I.], v.59, n. 10, p. 38-41, 56-57, february 1961].

SALOMÓN, Luisa. Guri. Serie Las Horas Oscuras. Prodavinci, 2020. Disponible en https://guri. prodavinci. com/. Acceso el 6/1/2021.

SHAW, Philip. Modernism and the Sublime. In: LLEWELLYN, Nigel y RIDING, Christine [eds.]. The Art of the Sublime. London: Tate Research Publication, 2013. Disponible en https://www.tate.org.uk/art/research-publications/the-sublime/philip-shaw-modernism-and-the-sublime-r1109219. Acceso el 3/5/2020.

TSOFE, Avital et alii. Chromatic Vasarely effect. Vision Research, [S.I.], v.50, n.22, p. 2284-2294, oct. 2010. Disponible en http://www.sciencedirect.com/science/article/pii/S004269891000324X. Acceso el 26/1/2021 VERGARA, Luiz Guilherme. Momentos de luz/Almir Mavignier. São Paulo: Dan Galeria, 2008. Disponible en https://www.mavignier.com/dan-galeria-2008.html. Acceso el 15/10/2020.

PÁGINAS WEB

Almir Mavignier: www. mavignier.com

Carlos Cruz-Diez: www.cruz-diez.com

Daros Latinamerican Collection: www.daros-latinamerica.net

Fundación Otero Pardo: www.oteropardofoundation.org

Jesús Soto: www.jr-soto.com [Fuera del aire desde 31 de diciembre 2020, debido al fin de Flash Player]

Julio Le Parc: www.julioleparc.org

Museum of Fine Arts, Houston: www.mfah.org

Olafur Eliasson: olafureliasson.net

Revista Poiésis, Niterói, v. 23, n. 39, p. 253-277, jan./jun. 2022. [DOl: hittps://doi.org/10.22409/poiesis.v23i39.49156] 


\section{IMAGENS-LEMBRANCCA E IDENTIDADES NO CINEMA INTERCULTURAL DE TILA CHITUNDA}

Recollection-images and identities in the intercultural cinema of Tila Chitunda Imágenes-recuerdo e identidades en el cine intercultural de Tila Chitunda

> Fernanda Mendes de Mendonça [Universidade Estadual de Campinas, Brasil]

RESUMO Este artigo propõe uma reflexão sobre a presença das imagens de arquivo familiar apresentadas no curta-metragem FotogrÁFRICA, de Tila Chitunda, que nos encaminha a pensar junto ao conceito deleuziano de imagem-lembrança. Fazemos esta análise compreendendo o filme como produto de um cinema intercultural, que se situa na intersecção de dois regimes culturais de conhecimento, neste caso Brasil e Angola, países da rota do Atlântico Negro. Diante dessas imagens, acessamos o que é visível e virtual e exploramos seus aspectos paradoxais. Ao tempo em que se apresentam como registros familiares, as fotografias também expõem a opressão colonial e violência promovida contra identidades e individualidades.

PALAVRAS-CHAVE cinema intercultural; imagem-lembrança; identidade; experiências afro-diaspóricas

ABSTRACT This article proposes a reflection about the presence of the family archive images presented in the short film FotogrÁFRICA, by Tila Chitunda, which leads us to think with the Deleuzian concept of recollection-image. We carry out this analysis understanding the film as the product of an intercultural cinema, which is located at the intersection of two cultural knowledge regimes, in this case Brazil and Angola, countries on the Black Atlantic route. In view of these images, we access what is visible and virtual and explore its paradoxical aspects. At the time they are presented as family records, the photographs also expose colonial oppression and violence committed against identities and individualities.

KEYWORDS intercultural cinema; recollection-image; identity; afro-diasporic experiences

* Fernanda Mendes de Mendonça é mestranda do Programa de Pós-Graduação em Multimeios da Unicamp. E-mail: mendesdemendonca@gmail.com. Orcid: https:/ / orcid.org/0000-0001-9327-4083.

Revista Poiésis, Niterói, v. 23, n. 39, p. 278-291, jan./jun. 2022. [DOl: https://doi.org/10.22409/poiesis.v23i39.49114] 
MENDONÇA, Fernanda M. Imagens-lembrança e identidades no cinema intercultural de Tila Chitunda.

Revista Poiésis, Niterói, v. 23 , n. 39, p. $278-$ 291 , jan./jun. 2022. [DOI: https://doi. org/10.22409/poiesis.v23i39.49114]

Este documento é distribuído nos termos da licença Creative Commons Atribuição - Não Comercial 4.0 Internacional (CC-BYNC) (C) 2022 Fernanda M. Mendonça. Submetido: 11/3/2021; Aceito: 25/5/2021
RESUMEN Este artículo propone una reflexión acerca de la presencia de imágenes de archivo familiar presentadas en el corto FotogrÁFRICA, de Tila Chitunda, que nos lleva a pensar junto al concepto deleuziano de imagen-memoria. Realizamos este análisis entendiendo la película como producto de un cine intercultural, que se ubica en la intersección de dos regímenes de conocimiento cultural, en este caso Brasil y Angola, países de la ruta del Atlántico Negro. A la vista de estas imágenes, accedemos a lo visible y virtual y exploramos sus aspectos paradójicos. En el momento en que se presentan como registros familiares, las fotografías también exponen la opresión colonial y la violencia promovida contra identidades e individualidades.

PALABRAS CLAVE cine intercultural; imagen-recuerdo; identidad; experiencias afro-diaspóricas 
O que há no espaço entre culturas distintas? $\bigcirc$ que se compreende da amálgama Brasil-Angola, ambos colonizados por Portugal? O que se coloca na bagagem - física, dos bens materiais, e simbólica, dos bens sentimentais, - antes de cruzar o Atlântico? O que fica, o que vai e o que se perde no deslocamento? E como pensar em sobrevivência ou em formas de reexistência mesmo quando tudo ao redor projeta o apagamento? Refletindo sobre memórias, histórias, identidades e imagens do cinema intercultural produzido nas rotas do Atlântico Negro, localizamos o trabalho memorialístico e autobiográfico da diretora, roteirista e produtora Tila Chitunda. Primeira filha brasileira de uma família de angolanos, Tila nasceu e cresceu em Pernambuco, especificamente na cidade de Olinda. Os pais Amélia Sicato e Teodoro Chitunda e seus cinco filhos atravessaram o Atlântico nos anos 1970 como refugiados da guerra civil angolana, declarada logo após o país se tornar independente de Portugal.

Em entrevista transmitida pelo canal do YouTube do grupo Arqueologia do Sensível [2020], a cineasta relata que as fotografias que constituem o arquivo familiar foram recuperadas gradativamente e expostas na parede da sala de estar da casa de sua família em Olinda. Chitunda propõe um olhar para essas fotografias no curta-metragem FotográFRICA [2016]. Esse é o primeiro título da série documental em que investiga memória e identidades através de sua própria trajetória familiar entre Angola e Brasil. Até o momento, a série é constituída por outros dois títulos: Nome de batismo - Alice[2017] e Nome de batismo-Frances [2019]. Nestes curtas, a diretora explora a memória de sua família refugiada e a constituição de uma identidade afro-diaspórica revisitando [e questionando] a história de seu próprio nome: Alice Frances Tilovita Sicato Chitunda.

Propomos concentrar nossa análise no primeiro dos curtas, FotogrÁFRICA, e refletir sobre a presença e afetação das imagens de arquivo familiar atreladas ao conceito de imagem-lembrança [DELEUZE, 2005]. O cinema brasileiro é focalizado em perspectiva transcultural, compreendendo a obra como produto de um cinema realizado no Atlântico Negro. A narrativa do curta compila imagens de arquivo, entrevistas e narrativa em primeira pessoa, articulando o modo poético, que enfatiza a ambiguidade, as fragmentações e derivações no tempo e espaço; e o modo participativo, ao compartilhar o processo de escuta e escavação de memórias familiares em busca de outras perspectivas da história [NICHOLS, 2010].

Cabe observar aqui, considerando nossa recepção fílmica, que a produção evoca uma "leitura documentalizante" na qual a espectadora ou espectador presume como reais as asserções enunciadas 
no filme, como conceitua Odin [2012]. A diretora contribui com o acionamento desse modo de leitura ao apresentar materiais de arquivo, relatos orais e seu próprio testemunho. Esta última característica, inclusive, encaminha para a possibilidade de pensarmos o curta também como uma "EGO produção" [Odin, 1995], filme feito, em geral, para exibição pública, realizado por um membro da família que se expressa individualmente como um eu que não pretende preservar intimidades [confidências e confissões]. O autor distingue três estratégias comunicacionais assumidas nas EGO produções: regimes culturais de conhecimento, no caso Brasil e Angola. Essa característica expressa no cinema intercultural, como explana Laura Marks no livro The skin of the film, produz novas condições para o conhecimento original apagado ou reprimido por regimes dominantes e opressores, re-escrevendo histórias, produzindo arquivos, articulando memória pessoal e coletiva, assumindo outras perspectivas de olhar e construindo fabulações. Com o uso da montagem e através de exercícios imaginativos, torna-se possível a re-existência de imagens até então ausentes. compartilhar uma espécie de processo de "cura psicanalítica", fazer um testemunho e utilizar o espaço público de exibição como meio de comunicação com um ou mais membros da família.

Através de conversas com a mãe, Chitunda expõe conflitos e adaptações vivenciadas por sua família no movimento diaspórico. A narrativa se desenvolve a partir de dois elementos centrais: o jogo de búzios, oráculo comumente utilizado por religiões da diáspora africana e regido pelos Orixás, e o mural fotográfico exposto pela matriarca na parede da sala. FotográFRICA situa-se na intersecção de dois
Uma das características comuns aos filmes e vídeos interculturais é o gesto, ou ação, de revisitar a história oficial, contada sob o ponto de vista dos vencedores, para desconstruí-la, revelar as histórias coloniais e dar a ver outras histórias e formas de conhecimento cultural. Assumimos a compreensão de Marks sobre o cinema intercultural como uma arqueologia de pesquisa através das imagens que revelam vestígios 
e destroços de um passado invisibilizado, ocultado ou incompleto. O cinema intercultural trabalha em paradoxos, sem pretensão de encontrar uma só verdade, e articula um senso de percepção pelo senconstruir uma sólida biografia, com história e causalidade, mas se dispõe a colocar em atrito história e memória, objetivo e subjetivo, real e imaginário, descrição e narração, atual e virtual [MARKS, 2000; DELEUZE, 2005].

\section{IMAGENS E MEMÓRIAS}

Georges Didi-Huberman em Quando as imagens tocam o real questiona que "tipo de conhecimento pode dar lugar à imagem" e "que tipo de contribuição ao conhecimento histórico é capaz de aportar este conhecimento pela imagem". A imagem, nos pensamentos de Didi-Huberman, Gilles Deleuze e Walter Benjamin que aqui iremos imbricar, não é um simples recorte do mundo visível. Há nela sintomas, lembranças, sobrevivências e dialética que articulam outros tempos, fatalmente anacrônicos e heterogêneos. sível. As produções desse cinema não se propõem a

Gilles Deleuze cria variadas categorizações para a imagem [imagem atual, imagem virtual, imagem óptica, imagem-movimento, imagem-tempo...], mas propomos articular neste artigo principalmente a compreensão de imagem-lembrança - que inevitavelmente se articula a outros conceitos, como de imagem virtual e óptica. Antes de definirmos as imagens-lembrança, precisamos estabelecer as imagens cinematográficas a que nos referimos no cinema intercultural.

A partir das leituras de Bergson, Deleuze estipula o pensamento cinematográfico em: 1] imagem-movimento, que provoca um reconhecimento sensório-motor, orgânico, de causalidade, que aceita a subjetividade implicada na imagem para se sujeitar à forma hegemônica de percepção, ou seja, quando certa percepção predomina sobre outras possíveis; 2] e imagem-tempo, inorgânica, que demanda participação ativa e posicionamento da espectadora ou espectador perante a imagem, decidindo o que é relevante, questionando percepções, objetividades e subjetividades. É nesse último que se situa o cinema intercultural a que nos referimos. Também é através da imagem-

As noções de memória, montagem e dialética estão aí para indicar que as imagens não são nem imediatas, nem fáceis de entender. Por outro lado, nem sequer estão "no presente", como em geral se crê de forma espontânea. E é justamente por que as imagens não estão "no presente" que são capazes de tornar visíveis as relações de tempo mais complexas que incumbem a memória na história [DIDI-HUBERMAN, 2012, p. 213]. -tempo que se dá o acontecimento da imagem-lembrança.

Revista Poiésis, Niterói, v. 23, n. 39, p. 278-291, jan./jun. 2022. [DOl: https://doi.org/10.22409/poiesis.v23i39.49114]

\section{2}


A imagem-lembrança pode ser compreendida como uma memória sobre determinado fato ou momento [pessoal ou coletivo] que não é capturada, portanto não está visivelmente explícita na imagem que se olha. A imagem, cabe enfatizar, é pensada aqui como imaginal, ou seja, que remete propriamente à imagem e se diferencia do imagético que, por sua vez, relaciona-se à imaginação [SANTIAGO JÚNIOR, 2019]. A imagem-lembrança, assim, desafia a história pública e a memória privada, já que remete a um objeto ou acontecimento passado que não se encontra no repertório da imagem atual, que dá a ver o presente que passou. A possibilidade de existência das imagens-lembrança surge no contato com a imagem virtual, uma reação à imagem atual que revela, pelo contato sensível, rastros do passado que persistem e se conservam no presente [DELEUZE, 2005; 1996]. Essa definição se aproxima da imagem dialética pensada por Walter Benjamin, derivada dos destroços da história: ela pressupõe um campo dialético que, ao entrar em contato com o visível, gera um espaçamento entre observador e observado onde se evidencia a historicidade que os envolve. A imagem-lembrança, retomando Marks [2000], confronta o que não pode ser representado e busca colocar o "irrepresentável" em diálogo com a memória.
Relacionamos a concepção de memória aqui expressa com a definição de memória virtual de Didi-Huberman [2013]. Seu acontecimento surge do acesso à imagem por outras vias, que não a do visível, mas do visual. O visual não é visível porque não está no sentido de ser visto, contudo também não é invisível porque é capaz de impressionar o olhar. A concepção de visívele visual está para os conceitos deleuzianos de atuale virtual. Marks [2000] aponta que a imagem, em seu aspecto visívelou atual, é apenas o começo, sendo o movimento de olhar para as imagens o aspecto mais produtivo do cinema intercultural. É no encontro com as imagens de arquivo que se questiona a percepção do olhar e se convoca a espectadora ou espectador à ação de perceber tudo novamente e enxergar lacunas que resultam de "censuras deliberadas ou inconscientes, de destruições, de agressões, de autos de fé" [DIDI-HUBERMAN, 2012].

Partindo desses conceitos, direcionamos agora nosso olhar para algumas fotografias [Fig. 1 e 2] apresentadas em FotogrÁFRICA que remetem à juventude de dona Amélia, nascida em 1939 na região de Catabola, na missão evangélica de Chissamba, colonizada por Portugal. A maioria das fotos, apesar de constituir um arquivo familiar, pouco representa a individualidade da experiência de dona Amélia. O primeiro grupo de imagens 


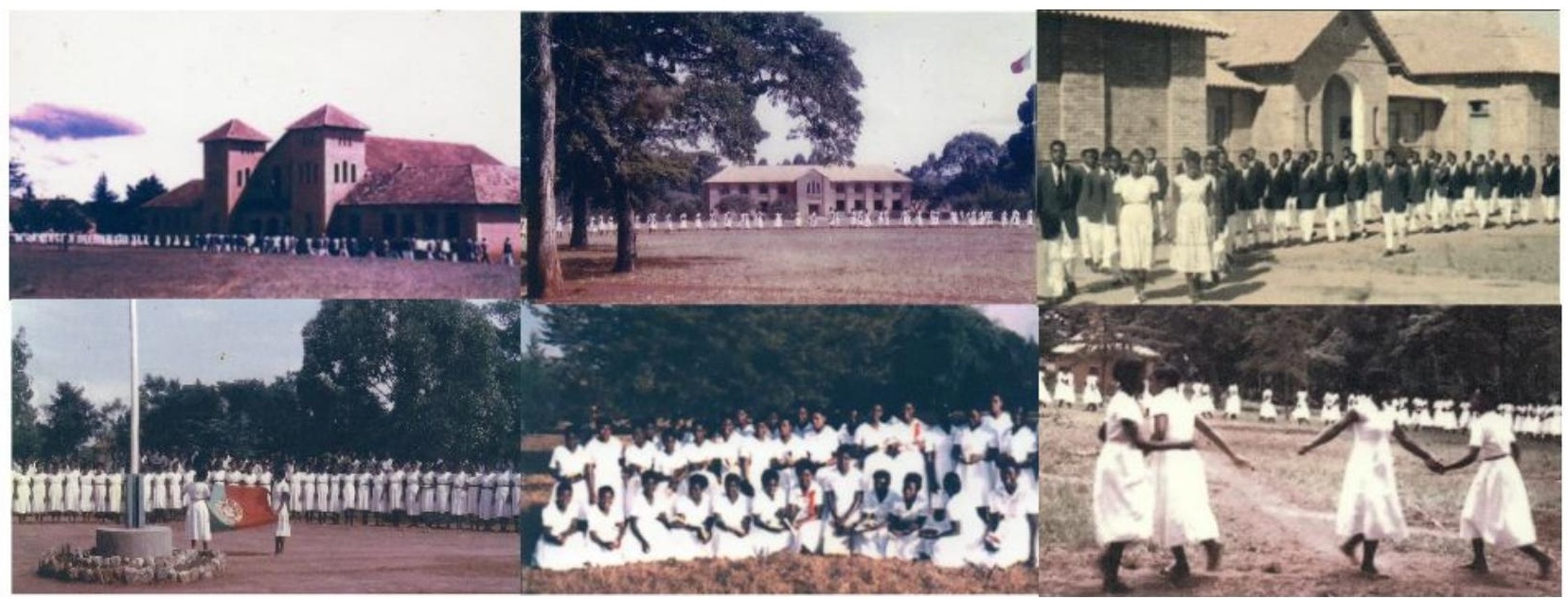

Fig. 1 - Montagem com fotografias apresentadas em FotogrÁFRICA

[Fonte: FOTOGRÁFrICA. Direção e roteiro Tila Chitunda, digital, cor, Pernambuco, Brasil, 25 mim., 2016]

[Fig.1] não aparece em destaque na parede da sala da matriarca por um motivo não dito, mas subentendido. O mural fotográfico montado por dona Amélia reúne fotografias que, como explica a personagem, têm a função de rememorar sua história: "Sempre que eu olho para aquela parede, Alice [Tila Chitunda], eu me lembro exatamente do que aconteceu. Então cada dia eu fico vitalizada com a história da minha família. Não esqueço nada". Esse olhar que rememora e combate o esquecimento - ou o apagamento histórico promovido contra povos colonizados nos relatos de conquista e dominação - nos leva a refletir sobre as imagens-lembrança, que implicam uma outra percepção, que não automática ou habitual, mas de reconhecimento atento [BERGSON apud DELEUZE, 2005]: percebemos de determinada coisa [de uma fotografia, neste caso] uma imagem óptica [e sonora]; uma percepção físico-geométrica e inorgânica, que não ocorre por causalidade.

Ao tempo em que são registros familiares, certas fotografias também são, a nível visível e virtual, registros da opressão colonial e violência cometida contra o povo angolano. Ainda que não haja a provocação para pensar a autoria das fotografias de arquivo apresentadas no curta-metragem ou como se deu o momento anterior ao da captura, em um exercício de imaginação podemos analisar que o autor [homem 
branco europeu, certamente] tinha o objetivo de documentar o sucesso da missão de Chissamba. Distanciado, o fotógrafo enquadra as estruturas arquitetônicas e acompanha cerimônias que mostram uma aglomeração ordeira de corpos negros [em maior parte femininos] reprimidos, dominados, obedientes, que caminham enfileirados e assistem ao hasteamento da bandeira que representa seus opressores.

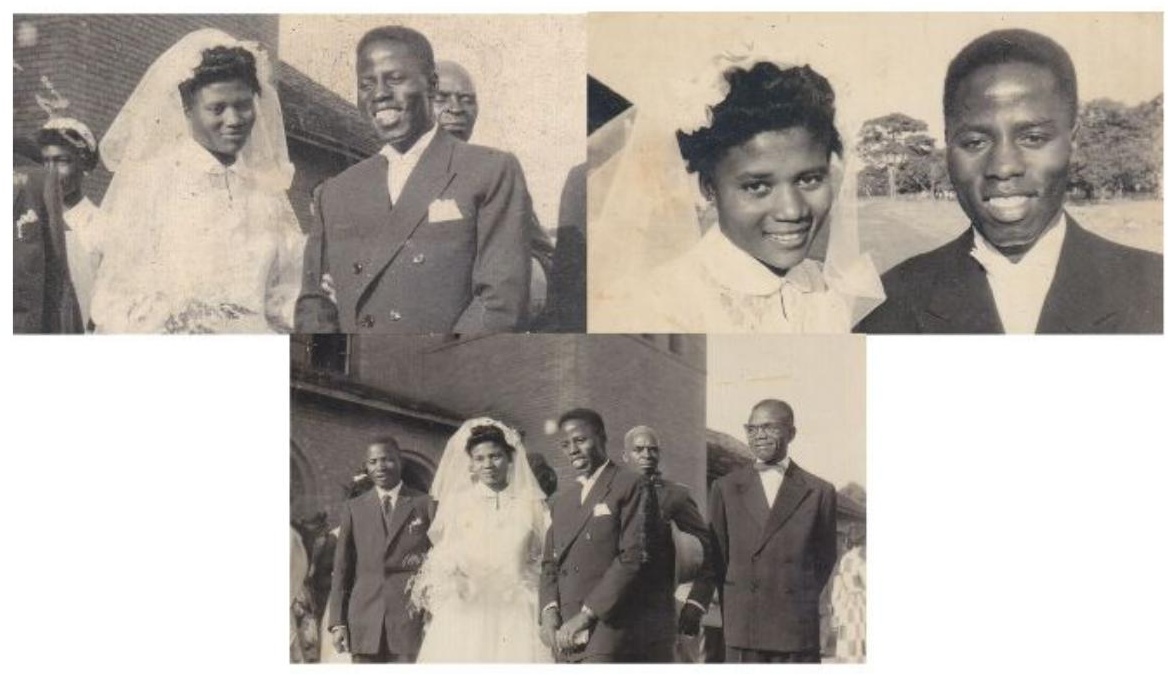

As fotografias não objetivam pluralizar os sujeitos e explorar suas individualidades, pelo contrário: invisibilizam suas diferenças de experiências, subjetividades, relações sociais e essencializam suas identidades [AVTAR BRAH, 2006]. Dezenas de mulheres negras de vestidos brancos e homens negros de ternos escuros participam de um ritual que lhes é estranho e notavelmente incômodo. Seus corpos, quando não aparecem enrijecidos, de cabeças baixas, braços para trás ou colados ao tronco, movimentam-se em uma coreografia que, ainda que remeta a uma identidade cultural própria, é registrada com o distanciamento de quem assiste à manifestação como um voyeur - afinal, para quem aquelas mulheres dançam?

Fig. 2 - Montagem com fotografias apresentadas em FotogrÁFRICA [Fonte: FOTOGRÁFRICA. Direção e roteiro Tila Chitunda, digital, cor, Pernambuco, Brasil, 25 mim., 2016.]

Na narrativa do curta, as três imagens que encerram a sequência de fotografias da missão de Chissamba têm mais proximidade física e afetiva. São registros de um momento da vida particular de dona Amélia: seu casamento [Fig. 2]. O branco do vestido usado na cerimônia de hasteamento da bandeira de Portugal que vemos na sequência anterior [Fig.1] se conecta com o branco do vestido de noiva em frente à igreja cristã. Essas fotografias, diferentemente das anteriores, aparecem expostas no mural da casa e geram um paradoxo entre os elementos simbólicos do processo de colonização e as memórias afetivas da história familiar. 
Outra imagem reveladora das violências simbólicas cometidas contra a existência de dona Amélia enquanto mulher negra nascida em Angola sob regime colonial é descrita oralmente. Seu imaginário guarda a lembrança dos desenhos de crianças "com um rabinho atrás" feitos nos registros de nascimento de sua família. Expondo a perspectiva dos colonizadores sobre os cidadãos de pele preta, ela diz: "O governo que nos colonizava era o gover- no português, ainda tinha a ideia de que o negro veio do macaco. [...] [O desenho era] Uma separação das crianças negras das famílias civilizadas, das crianças negras não civilizadas". A diretora cria uma sobreposição de retratos antigos de seus familiares que atravessam a imagem cinematográfica da entrevista com sua mãe, mostrando que a voz [e a imagem] que fala [e se mostra] no presente reverbera muitas outras antepassadas [Fig. 3].

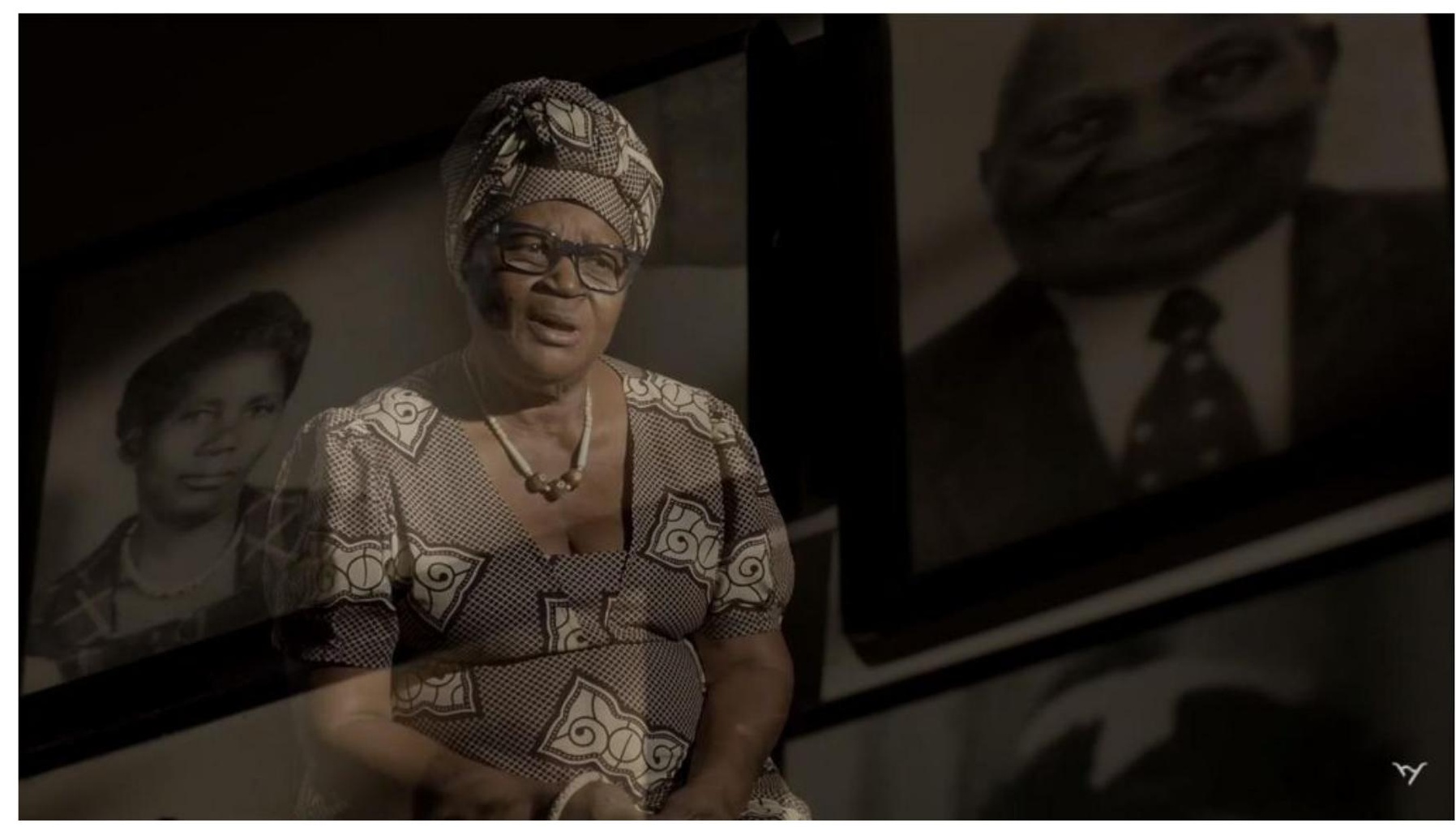

Fig. 3 - Frame com sobreposição de imagens apresentadas em FotogrÁFRICA

[Fonte: FOTOGRÁFRICA. Direção e roteiro Tila Chitunda, digital, cor, Pernambuco, Brasil, 25 mim., 2016.]

Revista Poiésis, Niterói, v. 23, n. 39, p. 278-291, jan./jun. 2022. [DOl: https://doi.org/10.22409/poiesis.v23i39.491 14] 
A narrativa revela imagens-lembrança acessadas por memórias que expõem feridas imaginais e imagéticas causadas por violências sistemáticas do regime colonial, mas que também acessam individualidades e evidenciam afetos possíveis. Chitunda, assim, investiga a rememoração e realiza um trabalho arqueológico, como propõe Marks [2000], nos convidando a olhar e ouvir não o que está visível ou é causal, mas o que está nas lacunas, na ausência, nas imagens-lembrança. Sua pesquisa através das imagens escancara a disjunção entre história oficial e memória privada que revela uma "outra história" em perspectiva, contribuindo com a diversificação do conhecimento histórico aportado pelo conhecimento pela imagem.

\section{TESOUROS VOLÁTEIS}

É necessário mover-se, colocar-se em ação, assumir o reconhecimento atento para possibilitar uma outra forma de acesso às imagens. Esse movimento, contudo, requer uma força, por vezes, dolorosa. As imagens-lembrança, imagens ópticas e virtuais a que nos referimos podem não ser reconciliadoras e, pelo contrário, revelar a incompletude ou "falsidade" da história oficial e das próprias memórias privadas.

\section{Em FotogrÁFRICA, Chitunda faz sua investigação} ciente dos processos implicados, ao narrar em off:

A história a que Chitunda se refere é a da origem de seus pais, crescidos na missão evangélica em Angola, passando pelo fim do regime colonial e enfrentando posteriormente uma guerra civil, condições essas que levaram a família a escapar de seu país de origem e se refugiar no Brasil, especificamente em Olinda, cidade que também se constitui, material e imaterialmente, por processos de colonização e transculturação. Chitunda remexe sua identidade diaspórica na busca por uma origem "pura", mas o que encontra são rastros, sobrevivências e outras formas de existência. 0 contato entre culturas decorrente dos processos coloniais implica disputas de poder, como destaca Stuart Hall em diálogo com Homi Bhabha, que inclui dominador e dominados. O poder não só oprime, invisibiliza, apaga, restringe e inibe: ele também "é produtivo; gera novos discursos, novos tipos de conhecimento [ou seja, o orientalismo], novos objetos de conhecimento [o Oriente] 
e forma novas práticas [colonização] e instituições [governo colonial]" [HALL, 2016, p. 196-197]. Assim, novas identidades e culturas são produzidas por processos de hibridização - na maioria dos casos promovidos forçadamente em situações de colonização, destruição e dominação - a partir das relações conflituosas e assimétricas de poder entre diferentes grupos [nacionais, raciais ou étnicos].

As interrogações feitas por Chitunda sobre seu passado a partir das imagens e do imaginário abre para constelações de sentidos e desconstrói a identidade absoluta e unificada de sujeitos afro-diaspóricos [DIDI HUBERMAN, 2016; HALL, 2016]. O cinema intercultural não apenas explora a intersecção de duas ou mais culturas, como gera novos discursos e conhecimentos culturais produzidos na diáspora. No curta, a imagem-lembrança evocada por uma pintura [não mostrada na imagem, mas apresentada descritivamente] de um Preto Velho da Umbanda exemplifica: enquanto o presbítero da igreja enxerga uma entidade, construída como a representação do pecado e do mal pela matriz cristã eurocêntrica, os pais de Chitunda lembram de um tio que morava com eles na missão em Chissamba. Quando se espera solidez e uma "nova" verdade universal, o cinema intercultural abre a terceira margem para um outro percurso: "eu nunca havia imaginado que o Preto
Velho pudesse ser evangélico", Chitunda fala em sua narrativa em off. As imagens que desestabilizam identidades fixas são os "tesouros voláteis para o cinema intercultural, porque se elas não podem falar por si, podem então ativar o processo de memória" [MARKS, 2000].

Articulando os pensamentos de Homi Bhabha e Kevin Robins, Hall [2006] aponta que os sujeitos das novas diásporas das migrações pós-coloniais habitam, no mínimo, duas identidades, pois já não estão próximos à tradição de uma cultura pura e original. Esses sujeitos gravitam em torno da tradução, quando são obrigados a "renunciar ao sonho ou à ambição de redescobrir um tipo de 'pureza' cultural ou de absolutismo étnico" por estarem submetidos ao plano "da história, da política, da representação e da diferença". Chitunda, ao consultar os búzios na cena de abertura do filme e iniciar sua narrativa almejando encontrar sua origem, tenta recuperar a tradição, mas essa intenção é apenas um ideal intangível. A tradução abre instâncias de complexidade e hibridismo: sua mãe, dona Amélia, praticante do cristianismo evangélico, recusa participar da roda de coco e não frequenta o Candomblé, mas ela também tornou-se referência de uma "mulher africana" na comunidade onde mora por usar torço [turbante] e trajes identificados como "típicos africanos". 
Na percepção de Mãe Beth de Oxum, outra personagem entrevistada por Chitunda em FotogrÁFR/CA que complexifica a definição das identidades, dona Amélia traz na oralidade e em sua imagem a África originária. Entretanto sabemos, a partir do contato com as fotografias do arquivo familiar, que a existência dessa identidade cultural não era possível na Angola colonizada, e só em Olinda, do outro lado do Atlântico, pôde encontrar possibilidades outras de expressão. Paul Gilroy, no livro Atlântico Negro, apresenta como alternativa à leitura romântica e nacionalista de uma "cultura negra pura" um modo transnacional e transhistórico de refletir sobre a experiência negra no mundo, compreendendo que as comunidades dos dois lados do Atlântico estiveram em intercâmbio desde os séculos 18 e 19. Combatendo essencialismos, relativismos e superando binarismos, o sociólogo, em diálogo com Stuart Hall [2006, 2016], defende a dupla consciência e a construção da identidade cultural como um processo de devir, com vontade e poder [GILROY, 2001].

Revelar as imagens-lembrança através de uma arqueologia da imagem praticada no cinema intercultural abre o rizomático arquivo da memória e história afro-diaspórica em FotogrÁFR/CA. Olhar para essas imagens - ainda que difíceis de dominar, organizare entender devido às lacunas e destroços da história - é se arriscar a colocar em interação, a partir de um exercício de imaginação e montagem, os rastros e traços de aspectos que sobreviveram em locais e tempos separados [DIDI-HUBERMAN, 2016]. A ancestralidade de Chitunda não está na Angola de seus pais e irmãos, como também não está no Brasil que a obriga tirar seus "Pretos Velhos da parede". Ela pode ser encontrada no espaço entre-Atlânticos, no Brasil-Angola e nas imagens- lembrança que remexem as cinzas daquilo que queimou, mas sobrevive, apesar de tudo.

NOTAS

[1] No original: "In the face of these erasures, intercultural cinema turns to a variety of sources to come up with new conditions of knowledge: written history, sometimes; the audiovisual archive; collective and personal memory; fiction; and the very lack of images or memories, itself a meaningful record of what can be expressed. Cultural knowledges are lost, found, and created a new in the temporal movement of history and in the spatial movement between places. In this chapter I dwell on archaeological models of cultural memory, while in the next chapter spatial acts of travel and physical contact will predominate. Intercultural cinema moves backward and forward in time, inventing histories and memories in order to posit an alternative to the overwhelming erasures, silences, and lies of official histories". 
BRAH, Avtar. Diferença, diversidade, diferenciação. Cad. Pagu [online]. 2006, n.26, pp.329-376.

CONVERSA aberta com Tila Chitunda. [S. I.: s. n.], 2020. 1 vídeo [128 min]. Publicado pelo canal Arqueologia do Sensivel. Disponivel em: https://www.youtube.com/watch?v=qq9 nyOOECXE. Acesso em: 08 jan. 2021.

DELEUZE, Gilles. A imagem-tempo - [Cinema 2]. São Paulo: Brasiliense, 2005.

DELEUZE, Georges. O atual e o virtual. In: ALLIEZ, E. Deleuze filosofia virtual. São Paulo: Ed.34, pp.47-57, 1996.

DIDI-HUBERMAN, Georges. Diante da imagem. Trad. Paulo Neves. São Paulo: Editora 34, 2013.

DIDI-HUBERMAN, Georges. Quando as imagens tocam o real. PÓS: Revista do Programa de Pós-graduação em Artes da EBA/UFMG, [S. I.], p. 206-219, 2012. Disponível em: https://periodicos.ufmg.br/index.php/revistapos/article/view/15454. Acesso em: 9 jan. 2021.

FOTOGRÁFRICA. Direção e roteiro Tila Chitunda, digital, cor, Pernambuco, Brasil, 25 mim., 2016. Disponível em: https://youtu.be/tsOhCWbgwQg. Acesso em: 08 jan. 2021.

GILROY, Paul. O Atlântico Negro. Modernidade e dupla consciência. São Paulo, Rio de Janeiro: 34/Universidade Cândido Mendes - Centro de Estudos Afro-Asiáticos, 2001.

HALL, Stuart. A identidade cultural na pós-modernidade. Rio de Janeiro: DP\&A, 2006.

HALL, Stuart. Cultura e representação. Rio de Janeiro: Ed. PUC-Rio: Apicuri, 2016. 
MARKS, Laura. U. The skin of the film: Intercultural Cinema, Embodiment, and the Senses. Durham and London: Duke University Press, 2000.

NICHOLS, Bill. Introdução ao documentário. São Paulo: Papirus, 2005.

ODIN, Roger. As produções familiares de cinema e vídeo na era do vídeo e da televisão. Cadernos de Antropologia e Imagem, UERJ, Rio de Janeiro, n. 17, p. 159-172, 2003.

ODIN, Roger. Filme documentário, leitura documentarizante. Significação: Revista de Cultura Audiovisual, [S. I.], v. 39, n. 37, p. 10-30, 2012. DOl: 10.11606/issn.2316-7114.sig.2012.71238. Disponível em: https://www. revistas.usp.br/significacao/article/view/71238. Acesso em: 3 jun. 2021.

SANTIAGO JÚNIOR, Francisco das Chagas Fernandes. A virada e a imagem: história teórica do pictorial/iconic/visual turn e suas implicações para as humanidades. An. mus. paul., São Paulo, v. 27, ed. 08, 2019. 
UNIVERSIDADE FEDERAL FLUMINENSE

REITOR

ANTONIO CLAUDIO LUCAS DA NÓBREGA

VICE-REITOR

FÁBIO BARBOZA PASSOS

PRÓ-REITORA DE PESQUISA, PÓS-GRADUAÇÃO E INOVAÇÃO

ANDREA BRITTO LATGE

PRÓ-REITORA DEGRADUAÇÃO

ALEXANDRA ANASTÁCIO MONTEIRO SILVADI

DIRETORIA DO INSTITUTO DE ARTE

E COMUNICAÇÃO SOCIAL

FLÁVIA CLEMENTE DE SOUZA

VICE-DIRETORA DO INSTITUTO DE ARTE

E COMUNICAÇÃO SOCIAL

CLARISSA SCHMIDT

COORDENADOR DO PPG EM

ESTUDOS CONTEMPORÂNEOS DAS ARTES

RICARDO BASBAUM
ÁREA DE CONCENTRAÇÃO

ESTUDOS CONTEMPORÂNEOS DAS ARTES

LINHAS DE PESQUISA

Corpo - Cena - Crítica da Representação

Experiência - Conceito -Sonoridades

Lugar - Política - Institucionalidades

CORPO DOCENTE PERMANENTE

ANA BEATRIZ CERBINO

ANA PAULA KIFFER

ANDREA COPELIOVITCH

GABRIELA LÍRIO

GIULIANO OBICI

JORGE VASCONCELLOS

LEANDRO MENDONCCA

LIGIA DABUL

LUCIANO VINHOSA

LÚCIO AGRA

LUIZ GUILHERME VERGARA

LUIZ SÉRGIO DE OLIVEIRA

MARTHA RIBEIRO

PAULO KNAUSS

RICARDO BASBAUM

TANIA RIVERA

TATO TABORDA

VIVIANE MATESCO

WALMERI RIBEIRO

PROFESSORES COLABORADORES

JESSICA GOGAN

MARIA ALICE POPPE

MARIANA PIMENTEL 


\section{FICHA CATALOGRÁFICA}

Dados Internacionais de Catalogação na Publicação [CIP]

Revista Poiésis. Publicação do Programa de Pós-Graduação em Estudos Contemporâneos das

Artes da Universidade Federal Fluminense [2022, 294p., $21 \mathrm{~cm}$, il.].

Revisła Poiésis, Niterói, v. 23, n. 39, jan./jun. 2022. [Editor: Luiz Sérgio de Oliveira].

[Dossiê - Indigestos trópicos - Organização: Ana Carolina Prudente Nascimento, Ana Clara Silva Mattoso, Ana Sayeg Tranchesi, Augusto Melo Brandão e Thigresa Almeida]

Universidade Federal Fluminense; Pró-Reitoria de Pesquisa, Pós-Graduação e Inovação;

Instituto de Arte e Comunicação Social; Programa de Pós-Graduação em Estudos

Contemporâneos das Artes.

ISSN 2177-8566 [online]

1. Artes; 2. Práticas artísticas; 3. Crítica das artes; 4. Teorias das artes; 5. Cultura 
